UNIVERSIDADE DE SÃO PAULO

ESCOLA DE ENGENHARIA DE SÃO CARLOS

JULIANA SIMIÃO

Gerenciamento de Resíduos Sólidos Industriais em uma Empresa de Usinagem sobre o enfoque da Produção mais Limpa

São Carlos

2011 
JULIANA SIMIÃO

\section{Gerenciamento de Resíduos Sólidos Industriais em uma Empresa de Usinagem sobre o enfoque da Produção mais Limpa}

Dissertação apresentada a Escola de Engenharia de São Carlos da Universidade de São Paulo para a obtenção do título de Mestre em Hidráulica e Saneamento.

Área de Concentração: Saneamento

Orientador: Prof. Dr. Valdir Schalch

VERSÃO CORRIGIDA

São Carlos

2011 
AUTORIZO A REPRODUÇÃO E DIVULGAÇÃO TOTAL OU PARCIAL DESTE TRABALHO, POR QUALQUER MEIO CONVENCIONAL OU ELETRÔNICO, PARA FINS DE ESTUDO E PESQUISA, DESDE QUE CITADA A FONTE.

Ficha catalográfica preparada pela Seção de Tratamento da Informação do Serviço de Biblioteca - EESC/USP

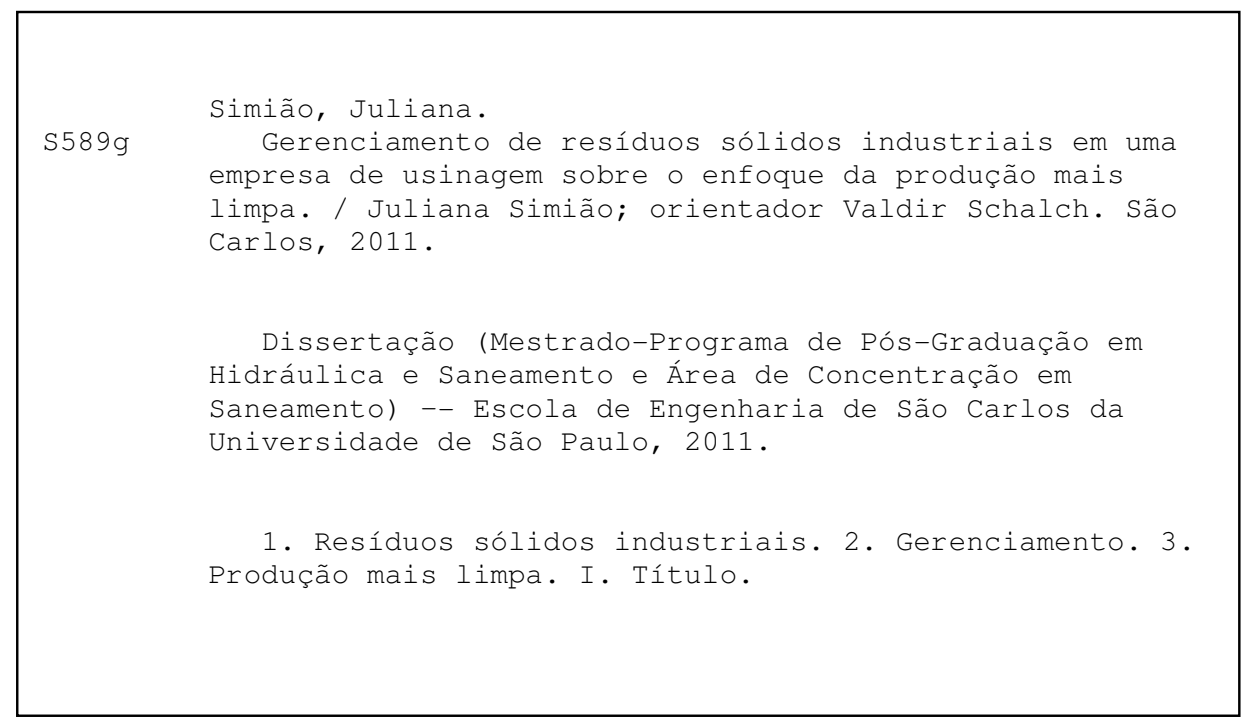


Candidato(a): Engenheira JULIANA SIMIÃo.

Dissertação defendida e julgada em 27/05/2011 perante a Comissão Julgadora:

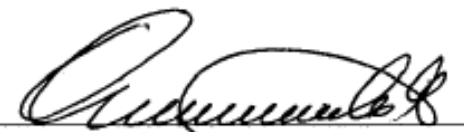

\section{APROVADA}

Prof. Associado VALDIR SCHALCH - (Orientador)

(Escola de Engenharia de São Carlos/USP)

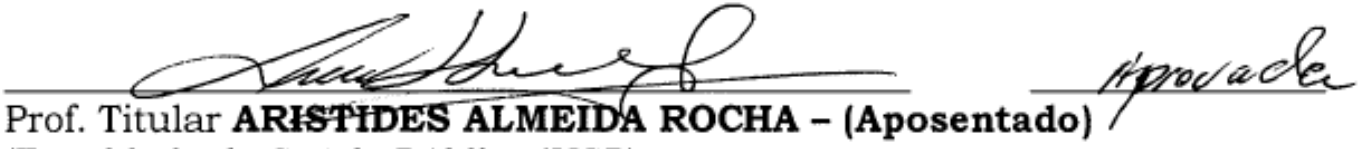

(Faculdade de Saúde Pública/USP)

\section{Carmenlucia Santos}

Prof $^{\mathrm{a}}$. Dr ${ }^{\mathrm{a}}$. CARMENLUCIA SANTOS

aprovada

(Universidade Estadual de Campinas/UNICAMP)
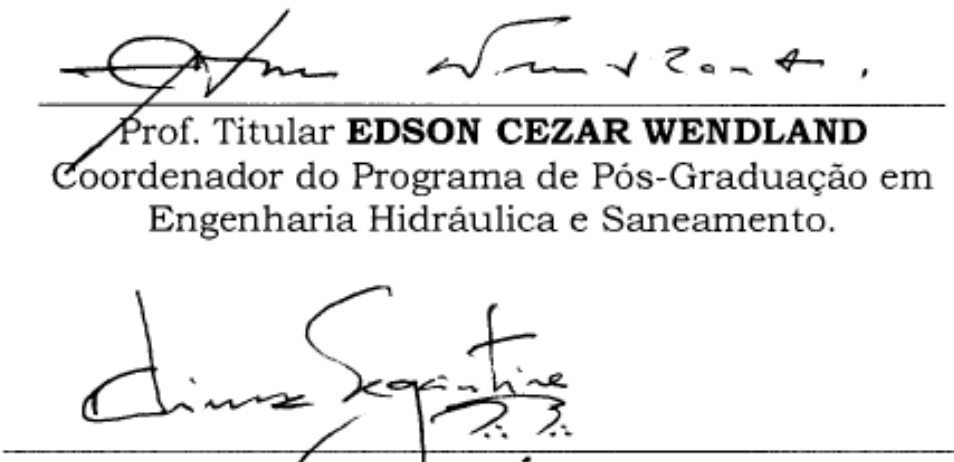

Prof. Associa to PAULO CÉSAR LIMA SEGANTINE

Presidente da Comissão da Pós-Graduação da EESC 


\title{
DEDICO
}

\begin{abstract}
A Deus, pela vida.
Aos meus pais, Sérgio Adão Simião e Regina Aparecida Versoza Simião, pelo imenso amor, motivação e incentivo.
\end{abstract}

A minha querida irmã, Heloísa Raquel Simião, pela amizade.

Ao meu amor, Zeffer Gueno de Oliveira, pelo carinho, paciência e apoio.

A toda a minha família e amigos que fazem parte da minha vida. 


\section{AGRADECIMENTOS}

Ao meu orientador, Valdir Schalch, pela oportunidade e ensinamentos.

Aos colegas do Mestrado pela ajuda no decorrer deste, em especial a Bianca Kancelkis e Lucas Marcon.

Aos colegas do Núcleo de Estudo e Pesquisa em Resíduos Sólidos (NEPER) pela troca de experiências, em especial ao Eduardo Rodrigues Ferreira, Rodrigo Eduardo Córdoba, Luís Gustavo Pila D’Aloia, Tatiana Corrêa e Marco Aurélio Soares de Castro.

Aos colaboradores da Empresa de Usinagem pela atenção e doação do seu tempo para o fornecimento das informações necessárias.

Aos funcionários do Departamento de Hidráulica e Saneamento pela atenção, em especial a Sá, Pavi e Rose.

Ao Conselho Nacional de Pesquisa (Cnpq) pelo apoio financeiro.

A todos que colaboraram com a elaboração desta dissertação. 
"O segredo de estar bem no mundo não reside no lugar onde estamos, mas na direção para a qual estamos indo."

Oliver Wendell Holmes 


\section{RESUMO}

SIMIÃO, J. Gerenciamento de Resíduos Sólidos Industriais em uma Empresa de Usinagem sobre o enfoque da produção mais limpa. 2011. 169 f. Dissertação (Mestrado) - Escola de Engenharia de São Carlos, Universidade de São Paulo, São Carlos, 2011.

As atividades industriais geram resíduos sólidos, de diferentes características e quantidades, que precisam ser gerenciados adequadamente para não causar poluição ambiental e danos à saúde do homem. A Lei n. ${ }^{\circ}$ 12.305/2010, que institui a Política Nacional dos Resíduos Sólidos, estabelece a seguinte ordem de prioridade no gerenciamento dos resíduos: não geração, redução, reutilização, reciclagem, tratamento dos resíduos e disposição final ambientalmente adequada dos rejeitos. A adoção destas estratégias no gerenciamento dos resíduos industriais é um desafio tendo em vista que a maioria das empresas ainda está focada na abordagem convencional de fim-de-tubo. Especial atenção ainda deve ser dada as empresas de pequeno e médio porte que costumam apresentar maiores dificuldades para o desenvolvimento de práticas de gestão ambiental por disporem de recursos financeiros mais limitados que empresas maiores, além de normalmente contarem com uma falta de estrutura organizacional adequada. A produção mais limpa pode ser uma importante aliada no gerenciamento dos resíduos sólidos, pois se trata da aplicação de uma estratégia técnica, econômica e ambiental integrada aos processos e produtos, com o objetivo de aumentar a eficiência no uso de matériasprimas, através da não geração, minimização ou reciclagem dos resíduos e emissões. Desta forma, o objetivo desta pesquisa foi avaliar, através de estudo de caso desenvolvido em uma empresa de pequeno porte do segmento de usinagem, as práticas de gerenciamento dos resíduos sólidos a partir da metodologia de produção mais limpa, com intuito de identificar oportunidades de otimização do gerenciamento dos resíduos sólidos na empresa avaliada. No diagnóstico constatouse que são gerados sete diferentes tipos de resíduos. O cavaco é o resíduo gerado em maior quantidade na empresa, sendo que da totalidade de barras de aço que entram para a produção da peça, $62 \%$ são convertidos em cavaco. Durante a usinagem da peça o cavaco arrasta o fluído de corte, havendo uma perda em média de $257 \mathrm{~L} / \mathrm{ano}$, o que em termos financeiros representa $\mathrm{R} \$ 10.000,00$ por ano. A empresa vende o cavaco contaminado com o fluído de corte para sucateiros da região. Constatou-se que para otimizar o gerenciamento dos resíduos é necessário, primeiramente, elaborar o Plano de Gerenciamento de Resíduos Sólidos (PGRS), que deverá ser analisado e revisado periodicamente, de forma que a empresa sempre possa alcançar novos objetivos e metas para a melhoria contínua do processo. Além disso, propõem-se: a realização de treinamentos para os funcionários quanto ao manuseio dos resíduos e as boas práticas de fabricação, adequar o armazenamento dos resíduos oleosos, exigir dos fornecedores padronização na dimensão das barras de aço e realizar a separação do cavaco e fluído de corte.

Palavras-chaves: Resíduos Sólidos Industriais; Gerenciamento; Produção Mais Limpa. 


\begin{abstract}
SIMIÃO, J. Industrial Solid Waste Management in a Machining Company focussed on cleaner production. 2011. $169 \mathrm{f}$. Thesis (MA) - School of Engineering of São Carlos, São Paulo University, São Carlos, 2011.

Industrial activities generate solid wastes of different characteristics and quantities, which must be managed properly to avoid causing environmental pollution and damage to human health. The Law 12.305/2010, National Solid Waste Policy, establishes the following order of priority in waste management: no generation, reduction, reuse, recycling, waste treatment and environmentally waste disposal. The adoption of these strategies in the management of industrial waste is a challenge considering that most companies still focussed on the conventional end-of-pipe. Special attention should be given to small and medium businesses that often have greater difficulties in the development of environmental management practices than larger companies. Other difficulties also are the limited financial resources and a lack of appropriated organizational structure. Cleaner production can be an important ally in the management of solid waste because it is the application of a technical, economic and environmental strategy integrated into processes and products. Its aim is to increase efficiency in the use of raw materials, as well the reduction and recycling of waste and emissions. Thus, the purpose of this study was to evaluate the waste management practices of a small machining business. Was used the methodology of cleaner production aiming to identify opportunities to improve the waste management in the machining company. At diagnosis was found that are generated seven different types of waste. The chip is the waste produced in greater quantity in the company, $62 \%$ of steel bars are converted into chip. During the machining process is lost cutting fluid with the chip. The average lost is of 257 liters of cutting fluid for year. In financial terms it represents loss of $R \$ 10,000.00$ per year. Nowadays the company sells the chip mixed with cutting fluid for scrap dealers in the region. To improve the management it was found that is first necessary to prepare the Solid Waste Management Plan (SWMP). The SWMP should be reviewed periodically so the company can always reach new goals and targets for continuous improvement of its process. Furthermore, was propose: training for employees regarding the handling of waste and good manufacturing practices, adequate storage of oily waste, require the standardization of the size of the steel bars and make the separation of the chip and cutting fluid.
\end{abstract}

Keywords: Industrial Waste, Management, Cleaner Production. 


\section{LISTA DE FIGURAS}

Figura 1 - Evolução da população mundial. .................................................23

Figura 2 - Diagrama esquemático de algumas definições utilizadas. ......................36

Figura 3 - Fluxograma do balanço de massa do processo industrial......................37

Figura 4 - Hierarquia do gerenciamento de resíduos. ......................................41

Figura 5 - Técnicas de redução da poluição...................................................... 42

Figura 6 - Caracterização e classificação dos resíduos sólidos. ............................46

Figura 7 - Ações reativas e preventivas no gerenciamento empresarial. .................49

Figura 8 - Etapas da metodologia do CEBDS para implantação da produção mais limpa

Figura 9 - Sistemática para a implementação de um programa de Produção mais Limpa.

Figura 10 - Etapas recomendadas pela CETESB para um programa de prevenção à

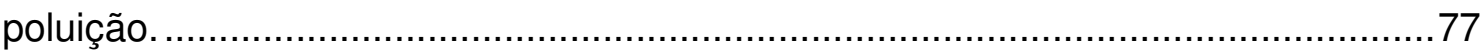

Figura 11 - Exemplo de Declaração de Intenções.............................................78

Figura 12 - Fluxograma qualitativo do processo produtivo. ................................ 82

Figura 13 - Análise quantitativa de entradas e saídas do processo produtivo..........83

Figura 14 - Representação da equação de balanço de material. .............................88

Figura 15 - Diagrama de causa e efeito. .......................................................91

Figura 16 - Classificação dos processos de fabricação da indústria metal-mecânica. ........99

Figura 17 - Sequência de formação da peça no processo de usinagem...............100

Figura 18 - Grandezas do processo de usinagem..........................................101

Figura 19 - Cinemática geral dos processos de usinagem...............................101

Figura 20 - Torneamento cilíndrico externo.................................................102

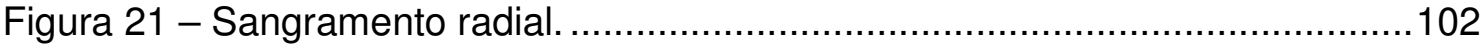

Figura 22 - Torneamento cilíndrico interno. ................................................... 103

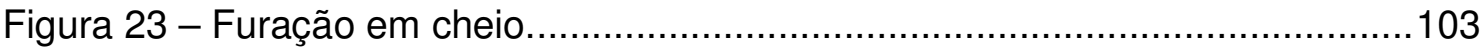

Figura 24 - Alargamento cilíndrico de acabamento. ....................................... 104

Figura 25 - Alargamento cônico de desbaste. .............................................. 104

Figura 26 - (A) Fresamento tangencial; (B) Fresamento frontal angular. ...............104

Figura 27 - Brochamento interno. ................................................................ 105 


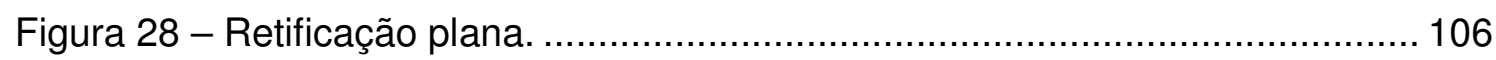

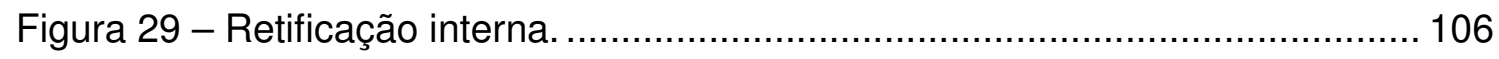

Figura 30 - Caracterização dos fatores ecológicos dos fluidos de corte. ................ 111

Figura 31 - Etapas do processo de produção da peça A..................................... 117

Figura 32 - Fluxograma qualitativo da etapa de usinagem da peça $A$. .................. 119

Figura 33 - Fluxograma quantitativo da etapa de usinagem da peça A................ 121

Figura 34 - Fluxograma de Gerenciamento de resíduos sólidos........................... 134

Figura 35 - Distribuição da matéria prima (barras de aço).................................... 139

Figura 36 - Distribuição do fluído de corte perdido no processo de usinagem da peça

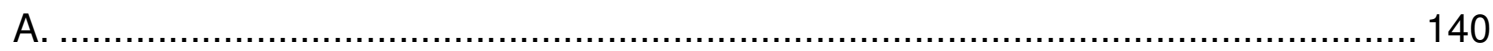

Figura 37 - Equipamentos de gerenciamento de fluidos utilizados nas operações de transformação de metais. ................................................................................ 143 


\section{LISTA DE FOTOS}

Foto 1 - Pesagem do cavaco na empresa.................................................. 122

Foto 2 - Bandeja de armazenamento de cavaco. .......................................... 124

Foto 3 - Tambor metálico para acondiciona-mento do cavaco..........................124

Foto 4 - Detalhe do cavaco acondicionado no tambor metálico. ...........................125

Foto 5 - Detalhe do suporte sob o tambor de cavaco onde é coletado o fluído de

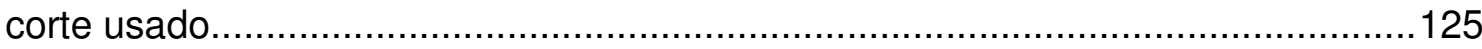

Foto 6 - Acondicionamento das pontas de barra e refugo..................................126

Foto 7 - Peça A pronta para expedição ao comprador. ........................................127

Foto 8 - Acondicionamento da ferramenta usada........................................... 127

Foto 9 - Área de armazenamento dos óleos....................................................128

Foto 10 - Acondicionamento dos panos sujos com óleo. ..................................129

Foto 11 - Reposição de panos limpos pela empresa de reciclagem. ....................129 


\section{LISTA DE QUADROS}

Quadro 1 - Histórico de incidentes/acidentes ambientais que chamaram a atenção do mundo para a importância da qualidade ambiental. 24

Quadro 2 - Diferenças entre as técnicas de fim de tubo e produção mais limpa. .... 48

Quadro 3 - Endereço na Internet de algumas Bolsas de resíduos no Brasil............ 53

Quadro 4 - Incompatibilidade de resíduos. ......................................................... 57

Quadro 5 - Critérios para o armazenamento de resíduos perigosos. ...................... 61

Quadro 6 - Vantagens e Desvantagens para o transporte de resíduos de acordo

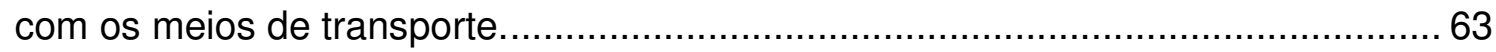

Quadro 7 - Exemplos de tratamentos possíveis para resíduos industriais............... 66

Quadro 8 - Vantagens e desvantagens do processo de tratamento de resíduos por

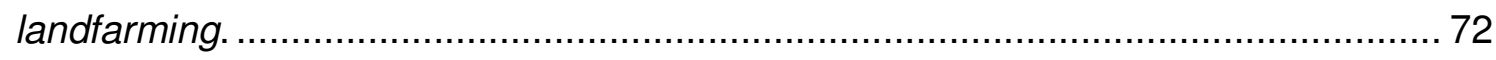

Quadro 9 - Exemplo de formação do ecotime e distribuição das responsabilidades. 79

Quadro 10 - Barreiras a implementação do programa de produção mais limpa. ..... 80

Quadro 11 - Exemplo de indicadores de desempenho operacional e gerencial. ..... 87

Quadro 12 - Lista de indicadores associados à geração de resíduos....................... 87

Quadro 13 - Possíveis fatores responsáveis pela geração de resíduos nas

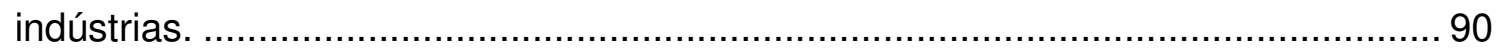

Quadro 14 - Questões a serem consideradas durante a avaliação técnica, ambiental e econômica das opções de produção mais limpa. .............................................. 95

Quadro 15 - Classificação e vantagens dos fluidos de corte líquidos.................... 108

Quadro 16 - Classificação dos resíduos de acordo com a NBR 10.004/2004 ...... 120

Quadro 17 - Forma de manuseio e gerenciamento dos resíduos. ......................... 130

Quadro 18 - Conteúdo para elaboração do PGRS. .......................................... 132

Quadro 19 - Proposição de ficha de resíduo para o fluído de corte esgotado. ...... 136

Quadro 20 - Medidas para evitar a contaminação e descarte do fluído de corte... 141

Quadro 21 - Métodos para separação do cavaco e fluído de corte nos processos de usinagem.

Quadro 22 - Resumo das oportunidades de melhoria no gerenciamento dos resíduos identificadas. 


\section{LISTA DE TABELAS}

Tabela 1 - Quantidade em massa das entradas e saídas. .................................122

Tabela 2 - Porcentagem dos resíduos/emissões gerados................................123 Tabela 3 - Indicadores do gerenciamento dos resíduos sólidos na Indústria $X$

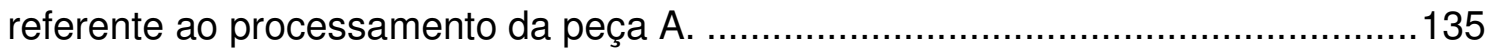
Tabela 4 - Comparação dos lucros anuais entre a situação atual e com a adoção de uma estratégia de produção mais limpa........................................................146 


\section{LISTA DE SIGLAS}

ABNT Associação Brasileira de Normas Técnicas

AIA Avaliação de Impacto Ambiental

CADRI Certificado de Movimentação de Resíduos de Interesse Ambiental

CEBDS Conselho Empresarial Brasileiro para o Desenvolvimento Sustentável

CETESB Companhia Ambiental do Estado de São Paulo

CMMAD Conferência das Nações Unidas sobre Meio Ambiente e

Desenvolvimento

CNC Computer Numeric Control

CNTL Centro Nacional de Tecnologias Limpas

CONAMA Conselho Nacional do Meio Ambiente

EPI Equipamento de Proteção Individual

ETE Estação de Tratamento de Efluentes

FIERGS Federação das Indústrias do Rio Grande do Sul

FIESP Federação das Indústrias do Estado de São Paulo

ICA Indicadores de Condição Ambiental

IDA Indicadores de Desempenho Ambiental

IDG Indicadores de Desempenho de Gestão

IDO Indicadores de Desempenho Operacional

ISO International Organization for Standartization

MINTER Ministério do Estado Interior

MQL Mínima Quantidade de Lubrificante

NBR Norma Brasileira

ONU Organização das Nações Unidas

$\mathrm{P}+\mathrm{L} \quad$ Produção mais Limpa

P2 Prevenção à Poluição

PERS Política Estadual de Resíduos Sólidos

PGRS Plano de Gerenciamento de Resíduos Sólidos

PME Pequena e Média Empresa

PNMA Política Nacional do Meio Ambiente 
PNRS Política Nacional de Resíduos Sólidos

PNUMA Programa das Nações Unidas sobre Meio Ambiente

SEBRAE Serviço Brasileiro de Apoio a Pequena Empresa

SENAI Serviço Nacional de Aprendizagem Industrial

SGA Sistema de Gestão Ambiental

SISNAMA Sistema Nacional do Meio Ambiente

SNVS Sistema Nacional de Vigilância Sanitária

SUASA Sistema Único de Atenção à Sanidade Agropecuária

UNEP United Nations Environment Programme

UNIDO United Nations Industrial Development Organization 


\section{SUMÁRIO}

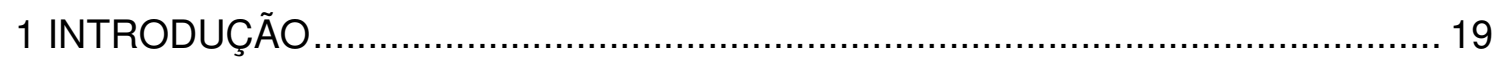

2 EVOLUÇÃO DO GERENCIAMENTO DOS RESÍDUOS SÓLIDOS...................... 22

2.1 Eventos e Conferências ambientais: rumo ao desenvolvimento sustentável .. 26

2.2 A Gestão ambiental nas indústrias ................................................ 29

3 GERENCIAMENTO DE RESÍDUOS SÓLIDOS INDUSTRIAIS .......................... 35

3.1 Classificação dos resíduos sólidos................................................... 43

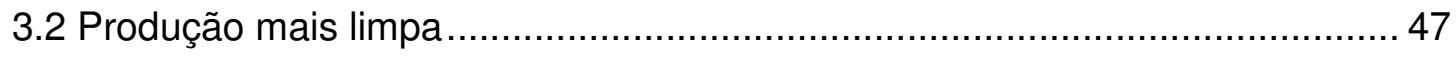

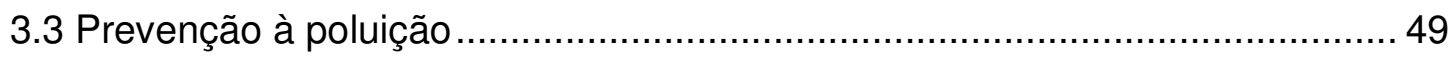

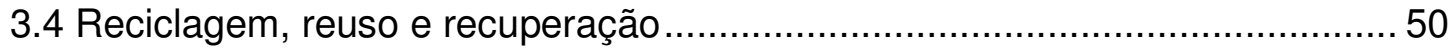

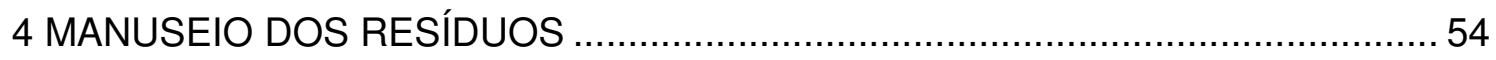

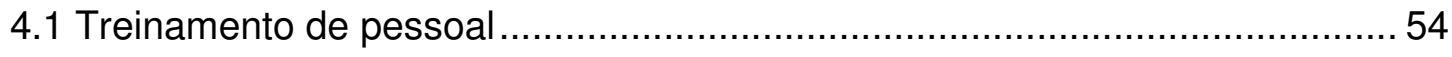

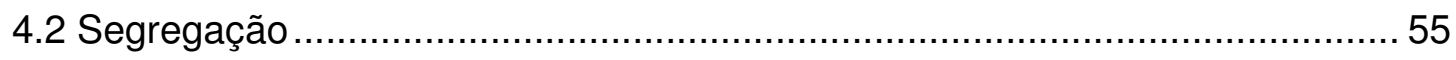

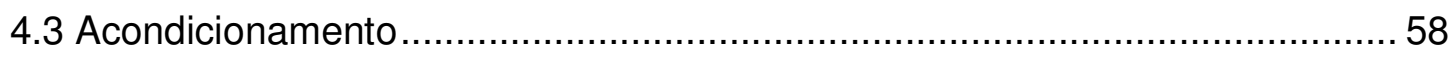

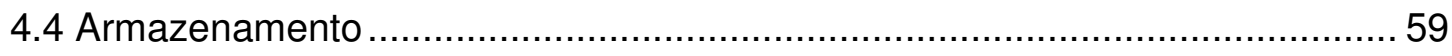

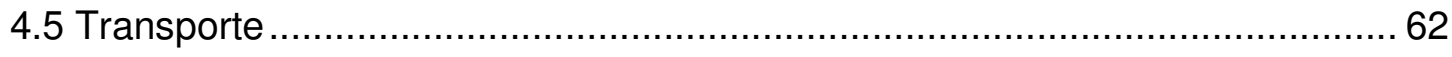

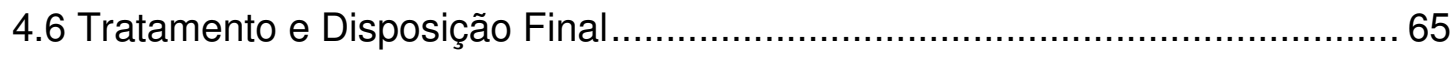

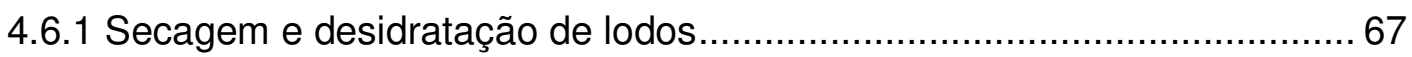

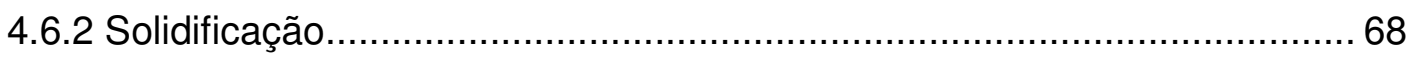

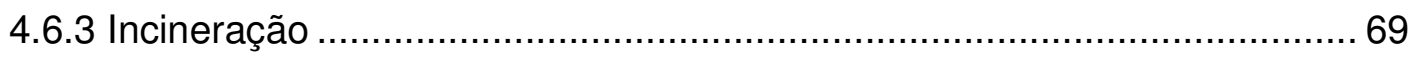

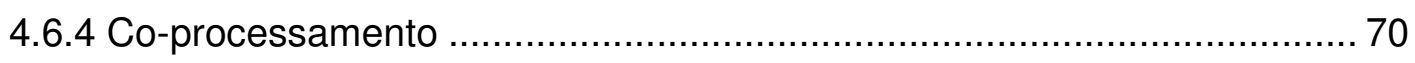

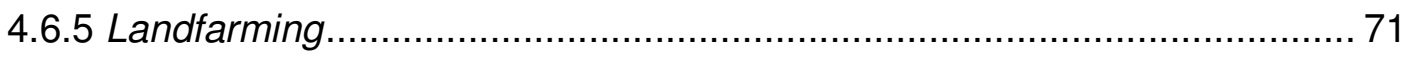

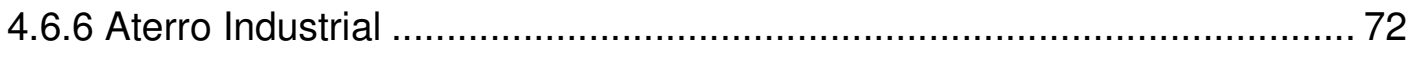

5 IMPLANTAÇÃO DE UM PROGRAMA DE PRODUÇÃO MAIS LIMPA .................. 74

5.1 Comprometimento gerencial ................................................................... 77

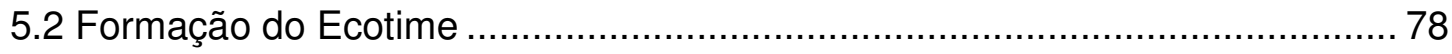




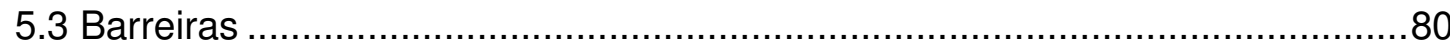

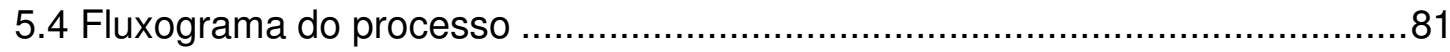

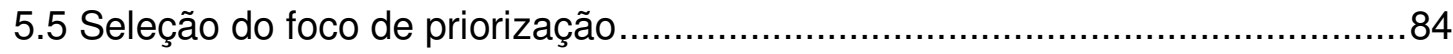

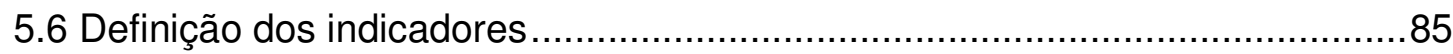

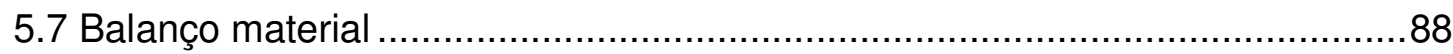

5.8 Identificação das causas da geração de resíduos ............................................89

5.9 Identificação das opções de produção mais limpa ……………………….....92

5.10 Avaliação técnica, ambiental e econômica e seleção de oportunidades ........94

5.11 Plano de implantação e monitoramento...........................................................96

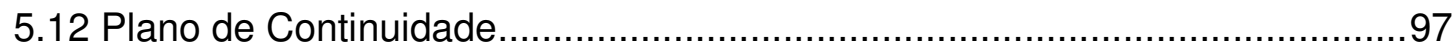

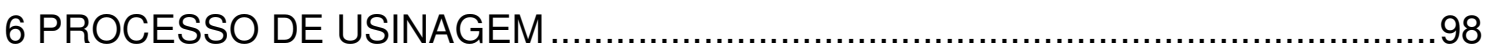

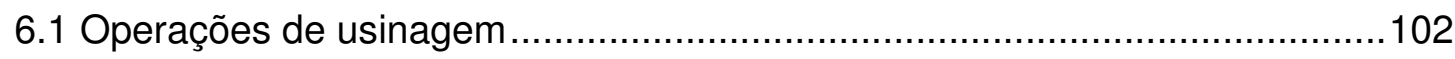

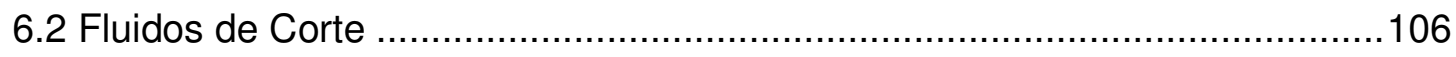

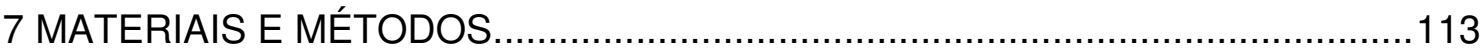

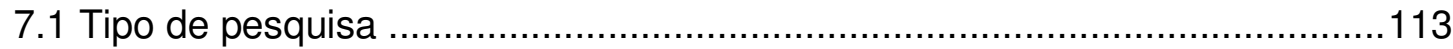

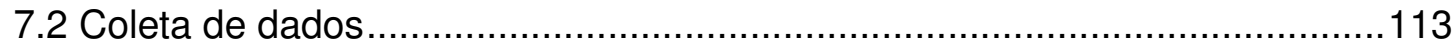

7.3 Caracterização da empresa objeto do estudo ............................................114

7.4 Justificativa da escolha da empresa alvo....................................................115

7.5 Delimitação do foco de estudo...............................................................116

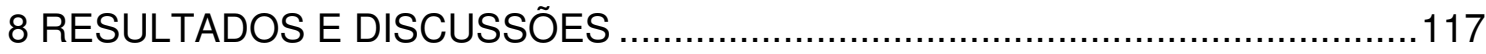

8.1 Descrição do processo produtivo ...............................................................117

8.2 Gerenciamento dos resíduos ..................................................................120

8.3 Proposição de melhorias no gerenciamento dos resíduos ............................131

8.3.1 Plano de Gerenciamento de Resíduos Sólidos ......................................131

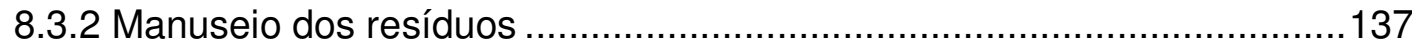

8.3.3 Oportunidades de produção mais limpa .................................................138

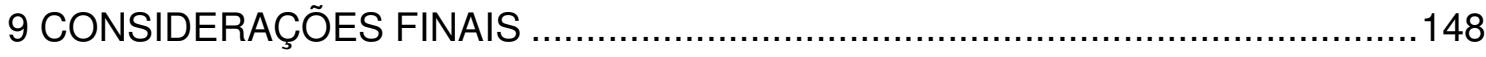




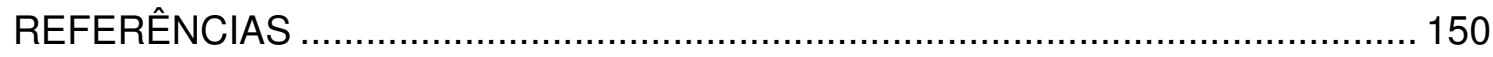

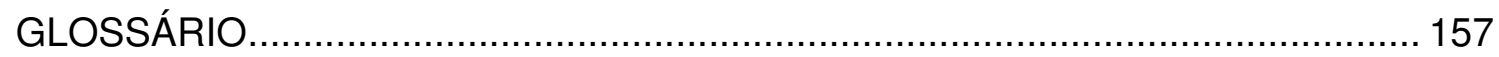

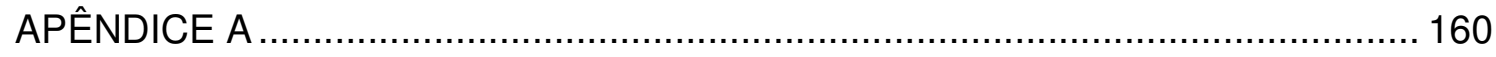

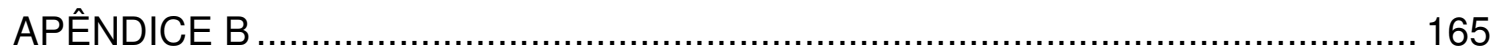




\section{INTRODUÇÃO}

As atividades industriais geram resíduos sólidos, de diferentes características e quantidades, que precisam ser gerenciados adequadamente para não causar poluição ambiental e danos à saúde do homem. Por muito tempo as práticas de manuseio consistiam apenas em lançar os resíduos o mais longe possível da fonte geradora sem preocupar-se com os efeitos decorrentes dessa ação.

A partir do despertar da necessidade de um desenvolvimento sustentável, que conduziu a regulamentações cada vez mais exigentes, as empresas foram levadas a tomar medidas para controlar a poluição ambiental.

Uma importante regulamentação na área dos resíduos, recentemente instituída, foi a Política Nacional de Resíduos Sólidos (PNRS), Lei n. ${ }^{0}$ 12.305/2010. A PNRS define gerenciamento de resíduos sólidos como um "conjunto de ações exercidas, direta ou indiretamente, nas etapas de coleta, transporte, transbordo, tratamento e destinação final ambientalmente adequada dos resíduos sólidos e disposição final ambientalmente adequada dos rejeitos" (Inciso $X$, art. $3^{\circ}$ ). Além disso, entre seus principais objetivos tem-se a não geração, redução, reutilização, reciclagem e tratamento de resíduos sólidos.

A Lei ainda especifica que essas ações devem estar de acordo com o Plano de Gerenciamento de Resíduos Sólidos, que deve ser elaborado para determinadas atividades, dentre estas as industriais. Através de um plano estruturado com metas e prazos definidos as empresas podem se organizar para alcançar melhorias contínuas no gerenciamento dos resíduos.

O desafio nesse sentido é adotar estratégias preventivas visando a redução ou eliminação da geração dos resíduos. A produção mais limpa pode ser uma importante aliada no gerenciamento dos resíduos sólidos, pois se trata da aplicação de uma estratégia técnica, econômica e ambiental integrada aos processos e produtos. Tem como objetivo aumentar a eficiência no uso de matérias-primas, água e energia, através da não geração, minimização ou reciclagem dos resíduos e emissões geradas, com benefícios ambientais, de saúde ocupacional e econômicos (CNTL, 2003a).

O relatório "Produção mais limpa na América Latina e Caribe" (PNUMA, 2005), aponta que algumas iniciativas já vêm sendo tomadas pelo setor privado e 
pelo setor público no sentido de fomentar e promover estratégias de produção mais limpa e consumo sustentável no país. Como exemplo das iniciativas de maior destaque tem-se a criação de centros de produção mais limpa para a difusão do conceito, divulgação de estudos de caso, formação de consultores, assistência técnica e capacitação de empresas.

Apesar destas iniciativas o relatório Cleaner Production in Latin America and the Caribbean (CETESB \& UNEP, 2002a) identificou algumas barreiras para 0 desenvolvimento de ações de produção mais limpa na América Latina e Caribe. No caso do setor industrial o referido relatório identificou a falta de interesse e participação limitada devido ao desconhecimento de alternativas tecnológicas e comportamento reativo dos empresários - voltado para a resolução de problemas imediatos e atendimento à legislação de controle corretivo, além da falta de estrutura organizacional adequada que afeta principalmente as pequenas e médias empresas.

Da mesma forma, Santos (2005, p. 2) constatou que,

No Brasil e em muitos países em desenvolvimento, as práticas de
prevenção a poluição, quando existem, são adotadas por grandes
companhias, geralmente multinacionais, que dispõem de recursos
financeiros e incentivos para adotar tecnologias limpas e eficientes em seus
processos produtivos. Não existe uma divulgação ampla de estudos de caso
que possa fornecer uma fonte de informação para empresas de pequeno e
médio portes. Do mesmo modo, não existem incentivos políticos para a
disseminação de práticas de prevenção à poluição.

Seguindo esta linha, a presente pesquisa tomou como base a necessidade premente das empresas gerenciarem seus resíduos de maneira adequada e visando sua redução, tendo em vista não só os imperativos legais, mas também, as questões de sustentabilidade que devem ser perseguidas por todos os setores da sociedade. Além disso, notou-se que a maior dificuldade para a adoção de práticas de prevenção é sentida pelas pequenas e médias empresas.

Desta forma, o objetivo desta pesquisa foi avaliar, através de estudo de caso desenvolvido em uma empresa de pequeno porte do segmento de usinagem, as práticas de gerenciamento dos resíduos sólidos a partir da metodologia de produção mais limpa, com intuito de identificar oportunidades de otimização do gerenciamento dos resíduos sólidos na empresa avaliada. Como objetivos específicos, têm-se:

- Realizar um diagnóstico do gerenciamento dos resíduos praticado na empresa de usinagem, foco do estudo, identificando os resíduos sólidos gerados, sua fonte de geração, quantidades, armazenamento, coleta, transporte e disposição final; 
- Levantar as possíveis técnicas disponíveis na literatura de prevenção de resíduos sólidos para o setor de usinagem;

- Propor melhorias no gerenciamento dos resíduos sólidos e apontar as oportunidades de produção mais limpa na empresa estudada;

Com os resultados espera-se fornecer subsídios não só para a empresa de usinagem avaliada, como também para futuros trabalhos desenvolvidos nessa área, divulgando as práticas de produção mais limpa tanto no meio acadêmico quanto no industrial. 


\section{EVOLUÇÃO DO GERENCIAMENTO DOS RESÍDUOS SÓLIDOS}

O homem procura alternativas para a destinação dos resíduos, que são resultantes das suas atividades cotidianas, desde os tempos antigos. No período das sociedades primitivas os homens utilizavam os recursos naturais para a manutenção da vida e também para o lançamento dos resíduos.

No início dos tempos, a disposição de resíduos não representava um problema significativo pois a população era pequena e a quantidade de áreas disponíveis para a sua assimilação era grande. Os problemas com os resíduos passam a ser perceptíveis a partir do momento que os primeiros seres humanos começam a se congregar em tribos, aldeias e cidades, e a acumulação de resíduos torna-se uma conseqüência da vida (TCHOBANOGLOUS; THEISEN; VIGIL, 1993).

Nas cidades medievais a prática de jogar o lixo, restos de comida e outros resíduos sólidos, nas ruas não pavimentadas, estradas e terrenos vazios, levou a proliferação de ratos, e com eles suas pulgas, disseminando a peste bubônica. A falta de qualquer planejamento para o gerenciamento dos resíduos sólidos levou a epidemia de peste, a Morte Negra, que matou metade dos Europeus do século XIV e causou diversas epidemias subseqüentes, com altas taxas de mortalidade (TCHOBANOGLOUS; THEISEN; VIGIL, 1993).

A peste bubônica "obrigou os administradores públicos a desenvolverem técnicas de tratamentos de rejeitos mais sépticas e confiáveis. Daí surgiu a técnica de disposição em aterros sanitários, simples e de baixo custo." (CNTL, 2003b, p.11).

Os problemas de disposição dos resíduos sólidos intensificam-se com 0 desenvolvimento de uma sociedade tecnológica, evidenciada no início da Revolução Industrial na Europa. A partir deste período, com a evolução científica, houve um aumento significativo da população do planeta, que pode ser visualizado na Figura 1, onde é apresentada a evolução da população no planeta nos últimos 2.500 anos. 


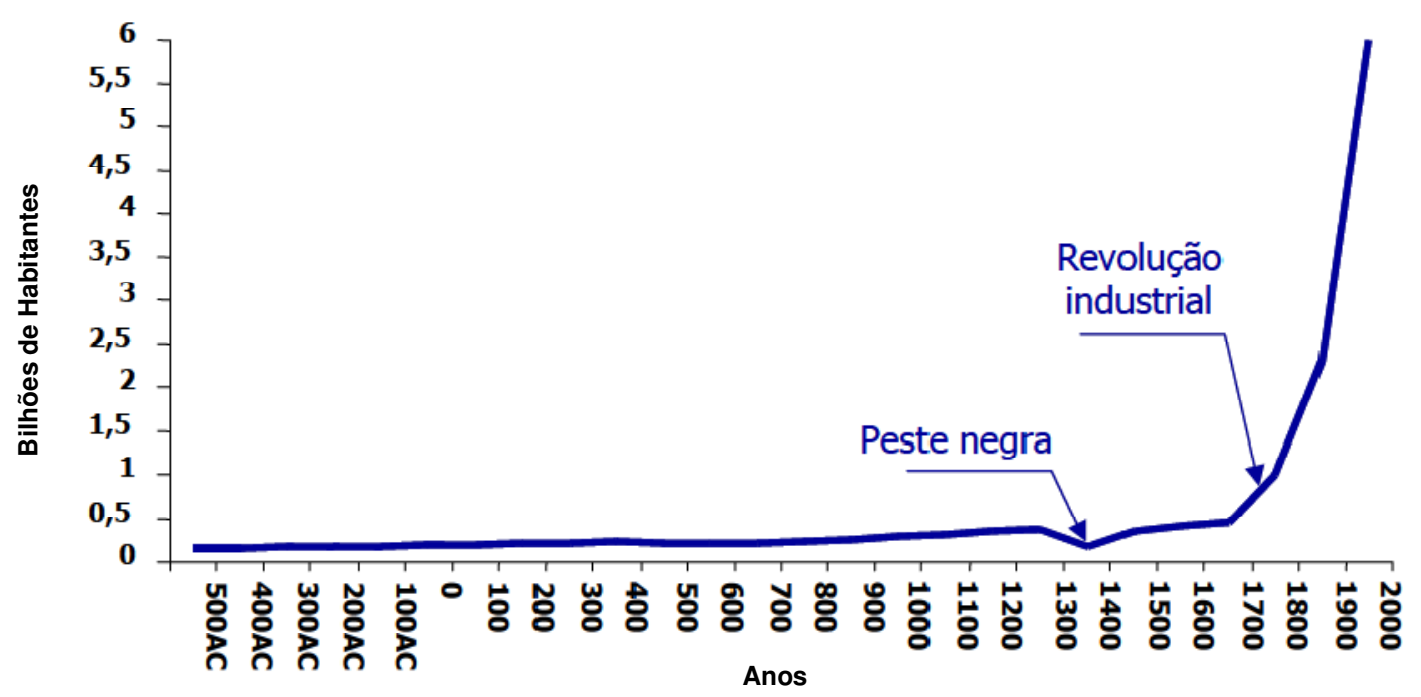

Figura 1 - Evolução da população mundial.

Fonte: Adaptado de CNTL, 2003b, p. 5.

Pelo gráfico é possível observar que entre 500 A.C. e 1.700 D.C., ou seja, durante 2.200 anos a população do planeta sempre esteve abaixo dos 500 milhões de habitantes. A peste bubônica foi um evento significativo para a diminuição do número de habitantes no século XIV, pois, como mencionado anteriormente, ela dizimou metade da população da Europa. Já a Revolução Industrial, ocorrida no século XVIII, serve de marco para a explosão demográfica ocorrida no planeta.

Dentre os possíveis fatores que contribuíram para este crescimento populacional acelerado pode-se mencionar o aumento da produção de alimentos, as melhorias das condições de vida nas cidades, o aperfeiçoamento do combate as doenças, as melhorias no saneamento básico e os benefícios obtidos com a Revolução Industrial. Todos estes fatores fizeram com que a taxa de mortalidade declinasse, ampliando assim o crescimento natural.

Este crescimento da população sugeriu uma série de mudanças sendo uma das mais importantes o aumento do consumo de recursos renováveis e nãorenováveis, conseqüentemente, colaborando para o aumento da quantidade de resíduos gerados.

Neste novo cenário o gerenciamento dos resíduos sólidos tornou-se mais complicado, pois a quantidade e variedade de resíduos gerados aumentaram e a capacidade de assimilação do meio ambiente começou a ser excedida. 
Tchobanoglous, Theisen e Vigil (1993) mencionam que na última parte do século XIX, as condições na Inglaterra eram tão ruins, que foi aprovada uma regulamentação em 1888 proibindo o lançamento de resíduos sólidos em valas ou nos rios.

A partir de meados do século $X X$, com o incremento significativo da quantidade de resíduos descarregados no meio ambiente, dá-se início, então, a uma seqüência de eventos/acidentes ambientais que começam a chamar a atenção da sociedade para a crescente degradação da qualidade ambiental, e, também, para o fato de que a qualidade de vida do homem e mesmo sua sobrevivência, a longo prazo, no planeta está por ela condicionada (LORA, 2000; SEIFFERT, 2007).

O quadro, a seguir, apresenta uma série de acidentes ambientais que ocorreram no mundo a partir da década de 50 e seus reflexos para o homem e o meio ambiente.

Quadro 1 - Histórico de incidentes/acidentes ambientais que chamaram a atenção do mundo para a importância da qualidade ambiental.

\begin{tabular}{|c|c|}
\hline Ano & Incidente/Acidente \\
\hline 1952 & $\begin{array}{l}\text { Na Inglaterra, na região de Londres, entre } 4 \text { e } 13 \text { de dezembro, grande parte das indústrias, } \\
\text { sobretudo as de geração de energia elétrica, e das residências que usavam carvão para a } \\
\text { produção de energia e calor, cuja queima emitia grande quantidade de enxofre e material } \\
\text { particulado na atmosfera, ocasionou um fenômeno denominado smog (contração das } \\
\text { palavras smoke e fog). O problema foi causado pela chegada de uma grande massa de ar } \\
\text { frio, vinda do Norte, ocorrendo uma inversão térmica. Depois de quatro dias com esse } \\
\text { mesmo quadro, houve em Londres mais de } 100 \text { mortes, decorrentes de ataques cardíacos } \\
\text { pela dificuldade de respiração. Cerca de } 8.000 \text { pessoas faleceram como conseqüência do } \\
\text { problema com bronquite, enfisema pulmonar, gripe, pneumonia, além de ataques } \\
\text { cardíacos. }\end{array}$ \\
\hline 1956 & $\begin{array}{l}\text { Contaminação da Baía de Minamata, Japão. Inicialmente, os efeitos da contaminação por } \\
\text { mercúrio foram detectados por gatos (Mal dos Gatos). Foram registrados casos de } \\
\text { disfunções neurológicas em famílias de pescadores, gatos e aves. A contaminação } \\
\text { acontecia desde } 1939 \text { devido a uma companhia química (Chisso) instalada às margens da } \\
\text { baía. Setecentos moradores mortos e } 9.000 \text { doentes crônicos devido às altas } \\
\text { concentrações de mercúrio, que causavam a doença "Mal de Minamata". Os sintomas } \\
\text { envolviam distúrbios sensoriais nas mãos e nos pés, danos à visão e audição, fraqueza e, } \\
\text { em casos extremos, paralisia e morte também de natureza teratogênica. }\end{array}$ \\
\hline 1976 & $\begin{array}{l}\text { Em Seveso, cidade italiana perto de Milão, a fábrica Hoffmann Roche liberou densa nuvem } \\
\text { de uma dioxina (Tetracloro Dibenzeno Dioxina - TCDD), um desfolhante (agente laranja), } \\
\text { altamente venenosa. Em virtude do acidente, ocorreram abortos e nascimento de crianças } \\
\text { sem cérebro (anencefalia) e com deformações físicas as mais diversas. Mais ou menos } \\
5.000 \text { italianos foram vítimas desse acidente. }\end{array}$ \\
\hline 1978 & $\begin{array}{l}\text { Um dos canais abandonados após a construção da Usina Niagara Falls (Love Canal) foi } \\
\text { utilizado pela empresa Hooker Chemical and Plastics como depósito de resíduos no } \\
\text { período de } 1942 \text { a } 1953 \text {. Posteriormente, a área foi aterrada e vendida para a construção } \\
\text { de um loteamento. Infelizmente, o playground acabou localizado exatamente sobre a antiga } \\
\text { área do canal. As crianças, principalmente, passaram a apresentar problemas de saúde: } \\
\text { câncer, distúrbios neurológicos e psicológicos. }\end{array}$ \\
\hline
\end{tabular}

Continua 


\section{Conclusão}

\begin{tabular}{|c|c|}
\hline Ano & Incidente/Acidente \\
\hline 1984 & $\begin{array}{l}\text { Um vazamento de } 25 \text { toneladas de isocianato de metila, ocorrido em Bhopal, Índia, causou } \\
\text { a morte de } 3.000 \text { pessoas e a intoxicação de mais de } 200.000 \text {. O acidente foi causado por } \\
\text { uma fábrica fornecedora da Union Carbide. No dia seguinte ao do acidente, o valor das } \\
\text { ações da Union Carbide caiu à metade, fazendo com que a companhia perdesse sua } \\
\text { posição de liderança no mercado mundial. }\end{array}$ \\
\hline 1985 & $\begin{array}{l}\text { É descoberto o buraco na camada de ozônio na Antártida. Em reunião na cidade de Villach, } \\
\text { Áustria, discute-se sobre o aumento crescente das emissões de dióxido de carbono e } \\
\text { outros gases de estufa na atmosfera, prevendo-se o aquecimento global. }\end{array}$ \\
\hline 1986 & $\begin{array}{l}\text { Explosão do reator da usina de Chernobyl (antiga URSS, atual Ucrânia), causado pelo } \\
\text { desligamento do sistema de refrigeração com o reator ainda em funcionamento. Provocou } \\
\text { um incêndio que durou uma semana, lançando na atmosfera um volume de radiação cerca } \\
\text { de } 30 \text { vezes maior que o da bomba atômica de Hiroshima. A radiação espalhou-se, } \\
\text { atingindo vários países europeus e até mesmo o Japão. Ocorreram } 80 \text { mortes e } 2.000 \\
\text { pessoas foram levadas aos hospitais. No prazo de cinco anos, supõe-se que o acidente } \\
\text { provocou câncer em } 135.000 \text { pessoas e nos próximos } 150 \text { anos em seus descendentes por } \\
\text { mutação genética. A rigor, considera-se que somente o Hemisfério Sul não foi afetado pelo } \\
\text { problema. }\end{array}$ \\
\hline 1986 & $\begin{array}{l}\text { Em Basiléia, Suíça, após incêndio em uma indústria foram derramadas } 30 \text { toneladas de } \\
\text { pesticidas no Rio Reno, causando a mortandade de peixes ao longo de } 193 \mathrm{Km} \text {. Foram } \\
\text { estimados cerca de } 500.000 \text { peixes e centenas de enguias mortos. }\end{array}$ \\
\hline 1987 & $\begin{array}{l}\text { Com a mudança do Instituto Goiano de Radioterapia, foram abandonados alguns aparelhos } \\
\text { de radioterapia, vendidos como sucata a um ferro velho. Ao abrir a cápsula, liberou-se o pó } \\
\text { radioativo (Césio 137) e, pouco tempo depois, as pessoas que freqüentavam o local } \\
\text { começaram a apresentar sintomas básicos de contaminação, como queimaduras por todo o } \\
\text { corpo, vômitos e diarréias. Com esse acidente, } 110 \text { pessoas foram contaminadas e quatro } \\
\text { morreram. }\end{array}$ \\
\hline 1989 & $\begin{array}{l}\text { O navio-tanque Exxon-Valdez, a partir de uma colisão, foi responsável pelo vazamento no } \\
\text { Alaska de cerca de } 44 \text { milhões de litros de petróleo. Considerado o pior da historia dos } \\
\text { EUA, atingiu uma área de } 260 \mathrm{~km}^{2} \text {, poluindo águas, ilhas e praias da região. Morreram } \\
\text { milhares de animais - peixes, baleias, leões-marinhos e aves, ameaçando a sobrevivência } \\
\text { de muitos pescadores da região. }\end{array}$ \\
\hline 2000 & $\begin{array}{l}\text { Por causa de uma falha na operação de um duto da Petrobrás, houve o vazamento de } 1,3 \\
\text { milhão de litros de óleo, contaminando as águas da Baía de Guanabara. A contaminação } \\
\text { estendeu-se por uma faixa de } 3 \mathrm{~km} \text {, atingindo praias da ilha de Paquetá e } 1.434 \text { hectares } \\
\text { da Área de Proteção Ambiental de Guapimirim, a reserva mais importante da Baía de } \\
\text { Guanabara, bem como uma área de manquezal. }\end{array}$ \\
\hline 2000 & $\begin{array}{l}\text { Ocorreu vazamento de óleo pelo rompimento de um duto sem válvula de segurança na } \\
\text { área do oleoduto pertencente à Petrobrás de São Francisco do Sul (SC), provocando o } \\
\text { derramamento de cerca de } 4 \text { milhões de litros de óleo bruto. Sua contaminação estendeu- } \\
\text { se por uma área de cerca de } 300.000 \mathrm{~m}^{2} \text {, atingindo Arroio Saldanha, e deste para o Rio } \\
\text { Barigüi e, em seguida, o rio lguaçu, formando mancha superior a } 8 \text { quilômetros. Isto } \\
\text { provocou a morte de cerca de } 60 \% \text { dos animais atingidos. }\end{array}$ \\
\hline 2002 & $\begin{array}{l}\text { O petroleiro Prestige, que pertence à firma grega Mare Shipping, encalhou diante do litoral } \\
\text { da Galícia (noroeste da Espanha), vindo a afundar no dia } 19 \text { a } 350 \mathrm{~km} \text { da costa espanhola } \\
\text { e derramando no mar } 20 \text { mil toneladas de óleo, segundo dados do Greenpeace. O } \\
\text { vazamento prejudicou a indústria pesqueira da Galícia, deixando na época } 4.000 \\
\text { pescadores e } 28 \text { mil trabalhadores temporariamente sem trabalho e um número } \\
\text { indeterminado de aves marinhas mortas ou cobertas de óleo. A mancha de óleo, cujo } \\
\text { tamanho estimado equivale à área da cidade de New York, foi localizada a cerca de } 4 \mathrm{Km} \\
\text { do litoral de Portugal. }\end{array}$ \\
\hline
\end{tabular}

Fonte: Elaborado a partir de Dias' , 2006; Moura $^{2}$, 2002; Tinoco e Kraemer ${ }^{3}, 2004$; apud Seiffert, 2007, p. 8-9.

\footnotetext{
${ }^{1}$ DIAS, R. Gestão Ambiental: responsabilidade social e sustentabilidade. São Paulo: Atlas, 2006.
} 
Além dos acidentes apresentados no Quadro 1 deve-se mencionar o derramamento de óleo no Golfo do México ocorrido em 20 de abril de 2010. O vazamento começou quando a plataforma de petróleo Deepwater Horizon, operada pela petroleira britânica BP, explodiu e afundou, matando 11 funcionários. A contenção do vazamento foi confirmada apenas no início de agosto, resultando no derramamento de 4,9 milhões de barris de petróleo no mar. Este acidente foi considerado como o pior vazamento costeiro na história dos Estados Unidos (ESTADÃO, 2010).

Como resultado destes incidentes/acidentes ao longo da história o homem começou, e continua, a repensar sua postura em relação ao usufruto dos recursos naturais que o cercam.

Esta preocupação materializou-se através de uma série de eventos de grande importância histórica fundamentais para a melhoria do controle ambiental nos ecossistemas urbanos que levaram ao amadurecimento dos conceitos de desenvolvimento sustentável e educação ambiental. Esses eventos foram induzidos pela maior percepção dos problemas ambientais, ao longo das décadas, e envolveram a atuação de especialistas na área ambiental, os quais buscavam propor soluções, analisando criticamente o então atual modelo de crescimento econômico de modo a melhor orientá-lo para a sustentabilidade (SEIFFERT, 2007, p 11).

\subsection{Eventos e Conferências ambientais: rumo ao desenvolvimento sustentável}

O impacto causado pelo homem no meio ambiente passa a ser alvo de reflexões e estudos. Em 1968 é criado o Clube de Roma constituído de pesquisadores de diversas áreas que estudaram o impacto global das interações dinâmicas entre produção industrial, a população, o dano ao meio ambiente, o consumo de alimentos e o uso de recursos naturais.

Como resultado desses estudos foi publicado, em 1972, o relatório denominado Limits to Growth (Limites do Crescimento). Segundo Moura ${ }^{4}$ (2002 apud SEIFFERT, 2007, p. 12), "o relatório previa que as tendências que imperavam até

\footnotetext{
${ }^{2}$ MOURA, L. A. A. Qualidade e Gestão Ambiental: sugestões para implantação das Normas ISO 14000 nas empresas. 3. ed. São Paulo: Juarez de Oliveira, 2002.

${ }^{3}$ TINOCO, J. E. P.; KRAEMER, M. E. P. Contabilidade e Gestão Ambiental. São Paulo: Atlas, 2004.

${ }^{4}$ MOURA, L. A. A. Op. Cit., nota 2.
} 
então conduziriam a uma escassez catastrófica dos recursos naturais e a níveis perigosos de contaminação no prazo de 100 anos."

No mesmo ano de 1972 foi realizada a Conferência das Nações Unidas sobre o Meio Ambiente Humano em Estocolmo na Suécia, com a presença de 113 países. Esta conferência foi cercada de impasses entre os países desenvolvidos e em desenvolvimento.

Os países desenvolvidos almejavam por uma reunião internacional na qual fosse dada ênfase aos aspectos relativos à poluição da água, do solo e da atmosfera. Além do esforço a ser empreendido pelos países industrializados, haveria a necessidade adicional de os países em desenvolvimento realizarem esforços de prevenção aos desequilíbrios ambientais em escala mundial. Os países em desenvolvimento por sua vez, se opuseram ao fato de as políticas preservacionistas que viessem a ser adotadas na Conferência pudessem servir como instrumentos de interferência nos assuntos domésticos ou como uma barreira à industrialização da África, América Latina e Ásia (SOARES, 2003, p. 42).

Apesar disso, a Conferência de Estocolmo representou um marco nas discussões sobre meio ambiente e desenvolvimento, já que foi a primeira manifestação dos governos de todo o mundo para discutir as conseqüências do crescimento econômico e populacional sobre o meio ambiente e quando foi inicialmente delineado o conceito de desenvolvimento sustentável, como pode ser observado nos Princípios da Declaração de Estocolmo, aqui sumarizados por McCormick ${ }^{5}$ (1989 apud SANTOS, 2005):

I. Os recursos naturais devem ser protegidos e conservados, a capacidade da Terra em produzir recursos renováveis deve ser mantida, e os recursos não renováveis devem ser racionalmente utilizados;

II. Desenvolvimento e meio ambiente devem andar lado a lado, e os países menos desenvolvidos devem receber assistência e incentivo para promover 0 gerenciamento ambiental racional;

III. Cada país deve estabelecer seus padrões de gerenciamento ambiental e explorar seus recursos do modo que desejarem, desde que não coloquem em risco outros países. Deve existir cooperação internacional visando a melhoria da qualidade ambiental;

IV. A poluição não deve exceder a capacidade do meio ambiente em absorvê-la. E a poluição oceânica deve ser prevenida; e,

V. Ciência, tecnologia, educação e pesquisa devem ser usadas para promover a proteção ambiental.

\footnotetext{
${ }^{5}$ McCORMICK, J. The Global Environmental Movement. London: Belhaven Press, 1989.
} 
Outro importante resultado do evento foi a criação do Programa das Nações Unidas sobre Meio Ambiente (PNUMA), encarregado de monitorar o avanço dos problemas ambientais no mundo.

A Conferência de Estocolmo teve grande influência no mundo todo e inclusive no Brasil. Na década de 80, em grande parte dos países, surgiram leis regulamentando a atividade industrial no tocante a poluição. Segundo Soares (2003), o fato do Brasil hoje contar com uma legislação ambiental bastante desenvolvida e ter os ideais preservacionistas consagrados na Constituição Federal de 1988, deve-se em grande parte à consciência ambiental que a Conferência de Estocolmo provocou no país.

Em 1983 é formada pela Organização das Nações Unidas (ONU) a Comissão Mundial sobre o Meio Ambiente e Desenvolvimento (CMMAD), que tinha como objetivo examinar as relações entre o meio ambiente e o desenvolvimento e apresentar propostas viáveis, para a solução dos problemas existentes (SEIFFERT, 2007). Como resultado dos estudos desta Comissão foi publicado, em 1987, o Relatório de Brundtland, também conhecido como "Our Common Future" (Nosso Futuro em Comum), que apontava a pobreza e a desigualdade existente entre os países como uma das principais causas dos problemas ambientais.

Segundo Seiffert (2007) esse documento contribuiu para disseminar o conceito de desenvolvimento sustentável, que surge formalmente no seu bojo, introduzindo definitivamente a idéia de que o desenvolvimento econômico de hoje deve se realizar sem comprometer as necessidades das futuras gerações.

No Rio de Janeiro, em 1992, a ONU realizou a Conferência das Nações Unidas sobre Meio Ambiente e Desenvolvimento (CNUMAD), também denominada Cúpula da Terra, Eco 92 ou Rio 92.

O período de 20 anos compreendido entre as Conferências de Estocolmo e do Rio mostrou grandes mudanças no entendimento global da relação entre atividade econômica e sistemas ecológicos. Na Cúpula da Terra, existia um senso otimista de que estratégias preventivas anunciavam uma possível "mudança de curso", em que o desenvolvimento industrial e econômico poderiam tornar-se compatíveis com a manutenção do ambiente global (UNEP, 2002b).

Esta conferência deu origem entre outros documentos igualmente importantes, à Agenda 21, um documento-programa de ação que visa por em prática as declarações firmadas durante a conferência, e propõe entre outras coisas a redução da quantidade de energia e materiais utilizados na produção de bens e serviços, a disseminação de tecnologias ambientais e a 
promoção de pesquisas que visem o desenvolvimento de novas fontes de energia e recursos renováveis. Outro ponto abordado é a incorporação de custos ambientais nas decisões dos produtores e consumidores, de forma que os preços reflitam o valor total dos recursos utilizados e previnam a degradação ambiental (SANTOS, 2005, p. 9).

Pode-se afirmar que a Conferência de Estocolmo e a Rio-92 foram os dois eventos de maior significância mundial. Estes encontros foram marcados pela proposição de soluções alternativas para os problemas ambientais decorrentes do modelo de expansão econômica adotado desde a Revolução Industrial.

Segundo Santos (2005, p. 10),

Estes eventos demonstram em grande parte, a ampliação da consciência a respeito das questões ambientais por parte dos governos, da sociedade e da indústria. Atualmente estas três entidades estão percebendo que apenas tratar e dispor os resíduos corretamente não é suficiente. É preciso reduzir a geração de resíduos das atividades industriais em todas as etapas do seu ciclo de vida e promover a recuperação e o reuso dos resíduos. Estas ações contribuem para preservar as reservas de recursos naturais, prevenir a contaminação ambiental, prolongar a vida útil dos aterros, reduzir custos com o desperdício de materiais e com o tratamento e a disposição de resíduos, e vão ao encontro dos princípios do desenvolvimento sustentável.

\subsection{A Gestão ambiental nas indústrias}

No período pós Revolução Industrial as empresas preocupavam-se apenas com a eficiência de seus sistemas produtivos, de quanto e como produzir, para obter a maximização de seus lucros e minimização de seus custos. Os recursos naturais eram tidos como ilimitados, e a poluição era entendida como uma conseqüência inevitável dos processos industriais.

Mundialmente, até a década de 1970 a ênfase era na produtividade e o meio ambiente visto como fonte de recursos naturais inesgotáveis. Segundo Seiffert (2007, p. 51) "o paradigma imperante era dispersar os poluentes produzidos, e isso residia simplesmente em lançar os poluentes o mais longe possível da fonte geradora, evitando assim problemas com as partes interessadas ${ }^{6 "}$.

Desta forma, os resíduos e emissões eram apenas lançados no ambiente, sem qualquer preocupação das empresas com os possíveis impactos ambientais e a saúde humana decorrentes desta ação. As águas e o ar eram vistos como fontes de

\footnotetext{
${ }^{6}$ Qualquer indivíduo direta ou indiretamente afetado pelo desempenho ambiental de uma organização.
} 
diluição de resíduos, e a responsabilidade empresarial com os impactos ambientais decorrentes das emissões era praticamente inexistente.

Nas décadas de 1970 e 1980 o nível de degradação ambiental se agravou, principalmente pelo aumento da população e consumo de bens. Por outro lado, a legislação anterior a este período, que não tratava do tema ambiental, passa a contar com a Política Nacional do Meio Ambiente (PNMA) - Lei n. ${ }^{\circ} 6.938$, de 31 de agosto de 1981, e a Constituição Federal de 5 de outubro de 1988, esta última com um capítulo dedicado ao meio ambiente.

Como reflexo deste período, tradicionalmente, a gestão ambiental no Brasil, no que se refere aos processos produtivos, vem priorizando a abordagem de Comando e Controle, que se baseia na criação de dispositivos e exigências legais (comando) e de mecanismos para garantir o seu cumprimento (controle).

Essa abordagem tem resultado em ações pontuais, lidando com as atividades impactantes de forma isolada. Isto pode ser observado na maioria dos instrumentos da PNMA que se constituem, atualmente, nas principais ferramentas legais para a garantia da redução dos impactos ambientais negativos dos processos produtivos. Nessa categoria estão, por exemplo, o Licenciamento Ambiental, a Avaliação de Impacto Ambiental (AIA) e os padrões de qualidade ambiental.

Assim, para o atendimento aos padrões de emissão e qualidade ambiental, estabelecidos pela legislação brasileira, as empresas têm direcionado sua atenção a adoção de medidas corretivas de controle da poluição, também chamadas de fim de tubo.

Segundo Thomas $^{7}$ (1995, apud SANTOS, 2005) o controle fim de tubo apresenta restrições quanto a sua eficiência na promoção da sustentabilidade. $A$ principal delas é o fato de promover a transferência de poluentes de um meio para o outro, uma vez que o controle atua no sentido de neutralizar ou concentrar a carga poluente, para que o resíduo possa então ser adequadamente disposto em aterros, lançado na atmosfera ou em rios.

Desta forma, ao se tratar os resíduos são gerados subprodutos que também necessitarão de tratamento. Além disso, muitas vezes os resíduos secundários produzidos no tratamento são mais tóxicos ou difíceis de tratar do que os resíduos

\footnotetext{
7 THOMAS, S. T. Facility Manager's Guide to Pollution Prevention and Waste Minimization. 1 ed. Washington: BNA Books. 1995.
} 
originais (THOMAS ${ }^{8}, 1995$, apud SANTOS, 2005). Outro inconveniente é que este tipo de medida não reduz responsabilidades a longo prazo.

$\mathrm{Na}$ empresa, portanto, esse controle é realizado por meio de ações localizadas e pouco articuladas entre si, resultantes de uma postura reativa, na qual suas atenções são centralizadas sobre os efeitos negativos de seus produtos e processos produtivos mediante soluções pontuais (BARBIERI, 2007).

A partir da década de 1990, devido ao aumento das pressões por parte das regulamentações ambientais, um mercado competitivo e consumidores cada vez mais exigentes, as externalidades ambientais, antes desconsideradas pelas organizações, começam a ser tratadas como custo. Um marco importante deste período foi a Rio-92, pois as discussões passaram a ocorrer não apenas entre grupos ambientalistas, mas com uma participação mais efetiva da sociedade.

Segundo Santos (2005, p. 26),

A globalização da economia, o estabelecimento de leis ambientais mais efetivas, e o surgimento das Normas ISO 14.000 de gestão ambiental vêm contribuindo para uma evolução contínua no modo de pelo menos parte da indústria gerir suas atividades com relação aos impactos no meio ambiente. Os debates mais recentes envolvendo segmentos industriais e do governo, bem como a comunidade científica e representantes da sociedade civil, tem apontado para uma ampliação da conscientização na busca do desenvolvimento sustentável no seu verdadeiro sentido, buscando a prevenção no lugar da mitigação, e a preservação em contraposição ao desperdício.

Apesar de já serem visíveis algumas mudanças nas empresas brasileiras, a maioria ainda restringe sua responsabilidade ambiental ao atendimento da legislação de controle da poluição da água, do ar e do solo, com uma postura majoritariamente reativa.

O ideal seria a adoção de uma postura pró-ativa pelas empresas, que de acordo com Sanches (2000, p. 78) ocorre mediante:

[...] a incorporação dos fatores ambientais nas metas, políticas e estratégias da empresa, considerando os riscos e os impactos ambientais não só de seus processos produtivos mas também de seus produtos. Assim, a proteção ambiental passa a fazer parte de seus objetivos de negócios e o meio ambiente não é mais encarado como um adicional de custo, mas como uma possibilidade de lucros, em um quadro de ameaças e oportunidades para a empresa.

Uma avaliação realizada pelo Programa das Nações Unidas para o Meio Ambiente (PNUMA) em parceria com a Companhia Ambiental do Estado de São Paulo (CETESB), e divulgada no relatório "Produção mais limpa na América Latina e

\footnotetext{
${ }^{8}$ THOMAS, S. T. Facility Manager's Guide to Pollution Prevention and Waste Minimization. 1 ed. Washington: BNA Books. 1995.
} 
Caribe" (PNUMA, 2005), aponta algumas iniciativas que vêm sendo tomadas pelo setor privado e pelo setor público no sentido de fomentar e promover estratégias de produção mais limpa e consumo sustentável no país, dentre as quais merecem destaque:

- Centro Nacional de Tecnologias Limpas (CNTL), fundado em 1995, na unidade local do Serviço Nacional de Aprendizagem Industrial (SENAI), vinculado à Federação das Indústrias do Rio Grande do Sul (FIERGS). Entre as atividades do centro, destaca-se a divulgação de diversos estudos de caso (curtume, metalurgia) e realização de cursos de formação de consultores em produção mais limpa $(\mathrm{P}+\mathrm{L})$.

- Rede Brasileira de P+L, articulada pelo Centro Nacional de Tecnologias Limpas (CNTL); Serviço Brasileiro de Apoio a Pequena Empresa (SEBRAE) e Conselho Empresarial Brasileiro para o Desenvolvimento Sustentável $\left(\right.$ CEBDS $\left.^{9}\right)$. Possui núcleos de P+L em sete Estados - Bahia, Ceará, Mato Grosso, Minas Gerais, Pernambuco, Rio de Janeiro e Santa Catarina. Os núcleos de $\mathrm{P}+\mathrm{L}$ estão ligados às Federações de Indústrias locais e prestam serviços de diagnóstico ambiental, assistência técnica e capacitação em $\mathrm{P}+\mathrm{L}$ a empresas de diversos segmentos e atividades.

- Rede de Tecnologias Limpas e Minimização de Resíduos: rede criada em 1998, com o objetivo de divulgar o conceito de prevenção da poluição e expandir o uso de tecnologias limpas no setor industrial do Estado da Bahia. Conta com a participação da Universidade Federal da Bahia, Centro de Recursos Ambientais, Centro Federal de Educação Tecnológica da Bahia, Federação das Indústrias do Estado da Bahia e BRASKEM Petroquímica do Nordeste S.A.

- Centro Senai de P+L de São Paulo (CPC) - unidade ligada à Federação das Indústrias do Estado de São Paulo (FIESP), criado em 1998, com a atribuição de prestar assistência técnicas às indústrias interessadas em melhorar sua

\footnotetext{
9 Fundado em 1997, o CEBDS, representante do World Business Council for Sustainable Development (WBCSD), é uma coalizão dos maiores e mais expressivos grupos empresariais do Brasil. Para viabilizar sua estratégia, o CEBDS vem estreitando sua relação com o governo federal e hoje integra a Comissão de Política de Desenvolvimento Sustentável e da Agenda 21, Grupo Institucional de Produção Mais Limpa, Fórum Brasileiro de Mudança Climática, Conselho de Gestão do Patrimônio Genético, Fórum de Competitividade e Biotecnologia e outros órgãos que operam em nível ministerial.
} 
performance ambiental. Atua também na capacitação de recursos humanos em P+L.

Apesar destas iniciativas o relatório Cleaner Production in Latin America and the Caribbean (UNEP, 2002a) identificou algumas barreiras para o desenvolvimento de ações de produção mais limpa na América Latina e Caribe que são apresentadas a seguir.

- Na área governamental:

$\leftrightarrow$ falta de comprometimento governamental na priorização de ações de $\mathrm{P}+\mathrm{L}$, em função do desinteresse da sociedade pelas questões ambientais;

$\Leftrightarrow$ falta de suporte legislativo e legislação adequada que privilegie ações de caráter preventivo;

$\Leftrightarrow$ falta de conhecimento sobre a qualidade ambiental, decorrente da inexistência ou inadequação de rede de monitoramento que permita um diagnóstico ambiental eficiente, bem como identificação do nexo entre a causa e o efeito como parâmetro principal no planejamento de ações de controle ambiental.

- Na indústria:

$\Leftrightarrow$ falta de interesse e participação limitada na implementação de ações de $\mathrm{P}+\mathrm{L}$, devido ao desconhecimento de alternativas tecnológicas e comportamento reativo dos empresários - voltado para a resolução de problemas imediatos e atendimento à legislação de controle corretivo. A falta de estrutura organizacional adequada afeta principalmente as Pequenas e Médias Empresas (PMEs).

4) dificuldade em realizar novos investimentos, decorrente do desconhecimento de linhas de crédito em $\mathrm{P}+\mathrm{L}$, juros excessivos cobrados pelos bancos locais, no contexto das crises econômicas e políticas dos países da região.

- No âmbito geral:

$\Leftrightarrow$ falta de conscientização sobre o tema $\mathrm{P}+\mathrm{L}$, denotando necessidade de maior treinamento e divulgação;

« dificuldade em manter e desenvolver centros de pesquisa dedicados ao conhecimento de tecnologias limpas e materiais alternativos;

$\Leftrightarrow$ falta de coordenação e sinergia entre os vários atores envolvidos com o tema - governo, indústria e sociedade. 
Nota-se portanto que ações já vêm sendo tomadas no sentido de desenvolver estratégias de produção mais limpa para serem aplicadas nas empresas, mas inúmeras barreiras ainda precisam ser vencidas, dentre elas pode-se elencar: a necessidade de maiores incentivos para a criação de tecnologias limpas, aumentar a disseminação das estratégias de produção mais limpa para que mais empresas possam estar aplicando-as de forma a tornar-se a longo prazo uma prática corriqueira; a criação de políticas públicas que incentivem a adoção de estratégias preventivas, juntamente com uma legislação que mude o atual sistema comando e controle; realização de parcerias entre as universidades $\mathrm{e}$ as indústrias, principalmente, as de pequeno e médio porte, para auxiliar no desenvolvimento de alternativas tecnológicas de prevenção cada vez mais acessíveis. 


\title{
3 GERENCIAMENTO DE RESÍDUOS SÓLIDOS INDUSTRIAIS
}

\author{
Santos, Yamanaka e Pacheco (2005, p. 23) afirmam que,
}

Todas as atividades humanas interagem, em maior ou menor grau, com o meio ambiente consumindo recursos (diretamente como a água, ou indiretamente como matérias- primas), modificando o espaço físico ou gerando rejeitos (resíduos sólidos, efluentes líquidos ou emissões atmosféricas).

Estas interações, entre as atividades humanas e o meio ambiente, são chamadas de aspectos ambientais. Quando esses aspectos não são devidamente controlados surgem efeitos no meio ambiente, conhecidos como impactos ambientais.

Todas as empresas, em diferentes graus de intensidade, geram aspectos que podem se converter em impactos ambientais. Mesmo pequenas indústrias que numa primeira análise parecem não provocar problemas ambientais podem causar sérios prejuízos caso não se tome o devido cuidado (SANTOS; YAMANAKA; PACHECO, 2005).

Dentre os aspectos gerados pelas indústrias que podem causar impactos ambientais têm-se os resíduos sólidos. "Os resíduos sólidos têm sua denominação derivada do latim: "residuu", que significa o que sobra de determinada substância, acompanhado da expressão "sólido" para diferenciar de líquidos e gases" (NAIME; GARCIA, 2004, p. 113).

A Associação Brasileira de Normas Técnicas (ABNT), a partir da norma técnica NBR 10.004/2004, define resíduos sólidos como: "resíduos nos estados sólido e semi-sólido que resultam de atividades de origem industrial, doméstica, hospitalar, comercial, agrícola, de serviços e de varrição" (ABNT, 2004a, p. 1). Incluem-se, ainda como resíduos, os lodos de tratamento de águas, aqueles gerados em equipamentos de controle de poluição, bem como determinados líquidos cujas particularidades tornem inviável o seu lançamento na rede pública de esgotos ou corpos de água, ou exijam para isso, soluções técnica e economicamente inviáveis, em face à melhor tecnologia disponível (ABNT, 2004a).

A legislação norte-americana define os resíduos sólidos como:

[...] qualquer tipo de lixo, refugo, lodo de estação de tratamento de esgoto, de tratamento de água ou de equipamento de controle de poluição do ar e outros materiais descartados, incluindo sólidos, líquidos, semi-sólidos, gás em contêineres resultantes de operações industriais, comerciais, de 
mineração e agrícolas, e de atividades da comunidade, porém não inclui sólidos ou materiais dissolvidos e esgoto doméstico, sólidos ou materiais dissolvidos na água de fluxo de retorno em irrigação e descargas pontuais [...] (USA ${ }^{10}, 1989$ apud PHILIPPI JR., 2005, p. 271).

Segundo Philippi Jr. (2005), os resíduos constituem subprodutos da atividade humana com características específicas, definidas geralmente pelo processo que os gerou. Do ponto de vista da sociedade, materiais descartados que são aproveitados deixam de ser resíduos, constituindo-se nas matérias-primas secundárias. E, quando os resíduos não têm aproveitamento econômico por nenhum processo tecnológico disponível e acessível são denominados rejeitos (Figura 2).

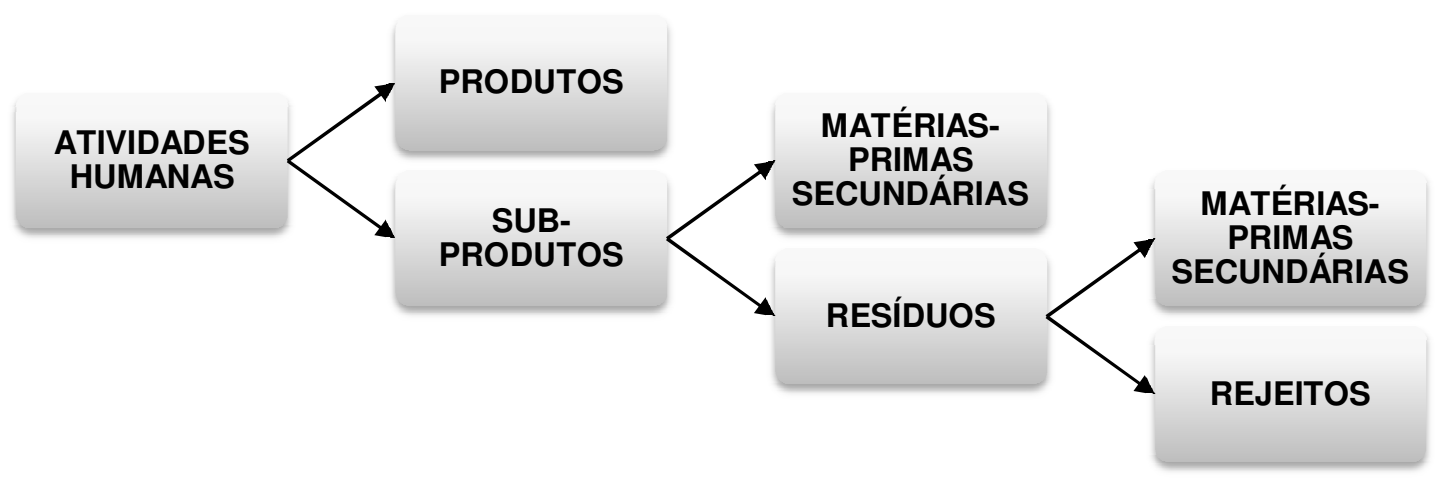

Figura 2 - Diagrama esquemático de algumas definições utilizadas.

Fonte: Philippi Jr., 2005, p. 272.

Nos processos industriais também são gerados subprodutos, resíduos e rejeitos. "Os resíduos industriais são gerados tanto nos processos produtivos quanto nas atividades auxiliares, como manutenção, operação de área de utilidades, limpeza, obras e outros serviços" (PHILIPPI JR., 2005, p. 292). A figura a seguir apresenta um balanço de massa com as principais entradas e saídas de um processo industrial com destaque para os resíduos, que englobam as matériasprimas secundárias e rejeitos.

\footnotetext{
${ }^{10}$ USA - The United States of America. Resource Conservation and Recovery Act of 1976 as amended. In: Hall Jr. RM, Watson T, Schwartz RE, Bryson NS, Davis Jr RC. RCRA Hazardous wastes handbook. $8^{a}$ ed. Rockville: Government Institutes; 1989. p. R1-131.
} 


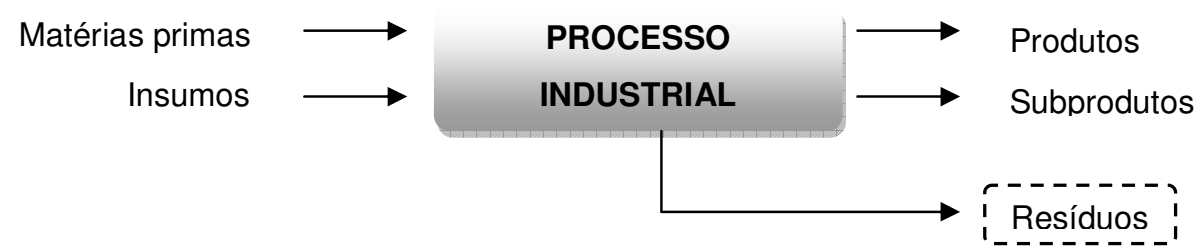

Figura 3 - Fluxograma do balanço de massa do processo industrial. Fonte: Modificado de Lora (2000), p. 435.

Para Philippi Jr. (2005) entre as atividades industriais que influenciam a geração de resíduos estão:

- Projeto do processo: os processos industriais podem ser projetados utilizando tecnologias alternativas. Algumas podem ser mais eficientes, outras menos, e algumas utilizam produtos mais perigosos que outros ou geram resíduos mais perigosos que outros. Por exemplo, a pintura com base d'água gera resíduos menos perigosos que a pintura com base de solvente; processo de recobrimento metálico por galvanoplastia sem cianetos geram resíduos menos perigosos que os processos com cianetos;

- Aquisição e armazenamento de matérias-primas: ao se adquirir matériasprimas de qualidade superior, há em geral uma contribuição para a melhoria da eficiência do processo. Além disso, utilizando-se matérias-primas mais puras, são gerados menores quantidades de resíduos e são rejeitados menos lotes com defeitos. A compra de excesso de matérias-primas pode gerar lotes rejeitados por conta de sua data de validade. Tais lotes freqüentemente não podem ser reaproveitados, gerando resíduos;

- Operações de produção: operações de produção e de controle de processo realizadas de maneira padronizada e com competência evitam acidentes e rejeição de lotes por defeitos, diminuindo a quantidade de resíduos. Esse controle deve incluir o treinamento dos operadores;

- Limpeza e manutenção de equipamentos: os equipamentos industriais devem ser periodicamente limpos, seja todos os dias, todas as semanas, todos os anos ou em intervalos mais longos, contudo, são raros os casos de equipamentos que nunca precisam ser limpos. Na atividade de limpeza são extraídos lodos, lamas, escórias, poeiras, óleos e outros materiais que constituem resíduos; 
- Derramamentos e vazamentos: líquidos que vazaram ou derramaram de seus contêineres originais precisam ser recolhidos, e em muitos casos não são mais aceitos pelo controle de qualidade para uso na produção. Muitas vezes os panos, estopas, serragem e outros materiais absorventes passam a fazer parte do próprio resíduo. Por isso e por outros motivos ambientais, os derramamentos e vazamentos devem ser evitados. No entanto, não é raro encontrar máquinas com vazamentos crônicos sob as quais a serragem se mantém de forma rotineira, e resíduos sendo transportados em carrinhos ou empilhadeiras sem a tampa do contêiner, provocando derramamentos.

De modo geral, Santos, Yamanaka e Pacheco (2005, p. 23) afirmam que os resíduos estão ligados a idéia de desperdício, e os descrevem de três maneiras:

- Uso ineficiente de equipamento, espaço, trabalho, tempo ou energia;

- Materiais gerados no processo que não podem ser reaproveitados;

- Gerenciamento deficiente de recursos.

Além do aspecto do desperdício e em virtude do seu caráter poluidor os resíduos devem ser gerenciados de maneira adequada pelas indústrias de forma a proteger, conservar e melhorar a qualidade do meio ambiente; contribuir para a saúde humana; e assegurar uma utilização prudente e racional dos recursos naturais.

Maia $^{11}$ (1992, apud LORA, 2000) conceitua o gerenciamento de resíduos sólidos industriais como o controle sistemático da geração, coleta, segregação na fonte, estocagem, transporte, processamento, tratamento, recuperação e disposição de resíduos.

Para Cardoso (2008) o gerenciamento de resíduos é um dos itens importantes em um Sistema de Gestão Ambiental ${ }^{12}$ (SGA) e deve visar à diminuição do impacto ambiental oriundo dos produtos e processos da organização, através da redução da geração de resíduos e do seu correto tratamento e destinação final.

$O$ adequado é que as organizações sistematizem o conjunto das iniciativas referente ao gerenciamento dos resíduos sólidos, elaborando os procedimentos para

\footnotetext{
${ }_{11}^{11}$ MAIA, A. L. D. A., et al. Gerenciamento de resíduos sólidos industriais. Belo Horizonte, 1992.

${ }^{12}$ Sistema de Gestão Ambienta (SGA) - parte de um sistema de gestão de uma organização utilizada para desenvolver e implementar sua política ambiental e para gerenciar seus aspectos ambientais. Um sistema de gestão inclui estrutura organizacional, atividades de planejamento, responsabilidades, práticas, procedimentos, processos e recursos. Para maiores detalhes consultar a norma ABNT NBR ISO $14.001 / 2004$.
} 
cada uma das etapas. Essa sistematização é denominada Plano de Gerenciamento de Resíduos Sólidos (PGRS).

Segundo Naime (2005), a elaboração adequada de procedimentos e normatizações para o gerenciamento de resíduos sólidos a serem adotados pelas organizações deve atender aos seguintes quesitos:

- Quais são os resíduos gerados, em que quantidade e onde (setor)?

- Quais as alternativas tecnológicas disponíveis?

- Qual o custo de cada alternativa?

- Quais são os riscos potenciais a curto, médio e longo prazo, considerando os aspectos técnicos, legais, penais, financeiros, éticos e morais?

Todo o sistema de gerenciamento deve ser documentado, para garantir a padronização e um controle operacional eficaz e despersonalizado. Para facilitar a documentação do sistema, deve ser estabelecido o fluxo dos resíduos, desde a sua geração até a destinação final, sendo identificados os responsáveis por cada uma das etapas que fazem parte do processo (NAIME, 2005).

A necessidade do estabelecimento de um controle das ações desempenhadas no gerenciamento dos resíduos faz parte inclusive de obrigatoriedade legal.

A Resolução CONAMA n. ${ }^{\circ}$ 313, de 29 de outubro de 2002, apresenta uma preocupação com a quantidade de resíduos industriais gerados e sua forma de manuseio. Esta Resolução dispõe sobre o Inventário Nacional de Resíduos Sólidos industriais, sendo que em seu artigo $4 .^{\circ}$ fica estabelecido que certas tipologias de indústrias $^{13}$ devem apresentar ao órgão estadual de meio ambiente informações sobre geração, características, armazenamento, transporte e destinação de seus resíduos.

Já a Lei n. ${ }^{0}$ 12.305/2010, recentemente aprovada, que institui a Política Nacional de Resíduos Sólidos estabelece em seu artigo 20 que os geradores de resíduos industriais devem elaborar o Plano de Gerenciamento de Resíduos Sólidos (PGRS). Conforme a Lei o PGRS deve conter no mínimo as seguintes informações (artigo $21^{\circ}$ ):

\footnotetext{
${ }^{13}$ Tipologias de indústrias previstas pela Resolução: preparação de couro, artigos de viagem e calçados; fabricação de coque, refino de petróleo, elaboração de combustíveis nucleares e produção de álcool; fabricação de produtos químicos, metalurgia básica; fabricação de produtos de metal, excluindo máquinas e equipamentos; fabricação de máquinas e equipamentos; fabricação de máquinas para escritório e equipamentos de informática; fabricação e montagem de veículos automotores, reboques e carrocerias; e fabricação de outros equipamentos de transporte.
} 
I - descrição do empreendimento ou atividade;

II - diagnóstico dos resíduos sólidos gerados ou administrados, contendo a origem, o volume e a caracterização dos resíduos, incluindo os passivos ambientais a eles relacionados;

III - observadas as normas estabelecidas pelos órgãos do Sisnama, do SNVS e do Suasa ${ }^{14}$ e, se houver, o plano municipal de gestão integrada de resíduos sólidos:

a) explicitação dos responsáveis por cada etapa do gerenciamento de resíduos sólidos;

b) definição dos procedimentos operacionais relativos às etapas do gerenciamento de resíduos sólidos sob responsabilidade do gerador;

IV - identificação das soluções consorciadas ou compartilhadas com outros geradores;

V - ações preventivas e corretivas a serem executadas em situações de gerenciamento incorreto ou acidentes;

VI - metas e procedimentos relacionados à minimização da geração de resíduos sólidos e, observadas as normas estabelecidas pelos órgãos do Sisnama, do SNVS e do Suasa, à reutilização e reciclagem;

VII - se couber, ações relativas à responsabilidade compartilhada pelo ciclo de vida dos produtos;

VIII - medidas saneadoras dos passivos ambientais relacionados aos resíduos sólidos;

IX - periodicidade de sua revisão, observando, se couber, o prazo de vigência da respectiva licença de operação a cargo dos órgãos do Sisnama.

$\mathrm{Na}$ elaboração do PGRS é primordial o estabelecimento de metas e procedimentos para minimização da geração de resíduos. As atividades industriais deverão cada vez mais priorizar a não geração de resíduos em seus processos, seguindo a hierarquia apresentada na Figura 4.

\footnotetext{
${ }^{14}$ Para maiores detalhes consultar Lista de Siglas.
} 


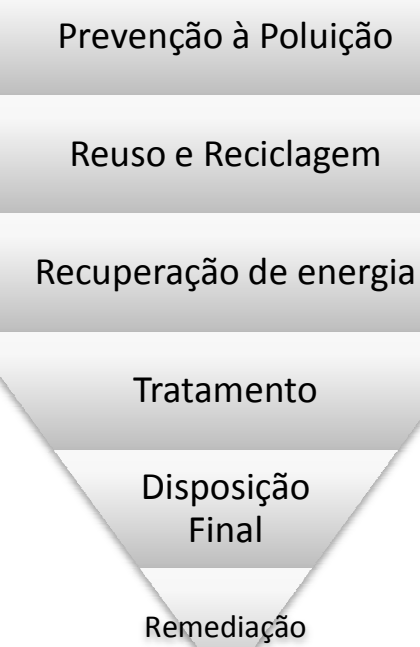

Figura 4 - Hierarquia do gerenciamento de resíduos. Fonte: Adaptado de Environment Canada, 2010.

O gerenciamento ideal dos resíduos sólidos industriais deve basear-se na adoção de medidas preventivas de eliminação ou minimização de resíduos, passando pela reciclagem e tratamento, até chegar na opção de menor prioridade, a disposição final e a remediação, que muitas vezes envolvem altos custos e riscos.

Atualmente, a maior parte das empresas tem centrado ainda seus esforços na disposição final e na remediação de áreas contaminadas, resultado do depósito inadequado de resíduos, com maiores prejuízos ao ambiente quando se tratam de resíduos perigosos.

Isso é o reflexo do modelo de gerenciamento que vêm sendo adotado desde a Revolução Industrial e das Leis de comando e controle, como já mencionado no capítulo 2.

Neste trabalho é dada ênfase às estratégias de prevenção à poluição dos resíduos sólidos, incluindo o reuso e a reciclagem, práticas que devem estar presentes no cotidiano não só das empresas como também de toda a sociedade.

Uma visão geral das técnicas usadas para a redução da poluição é apresentada na Figura 5 a seguir. 


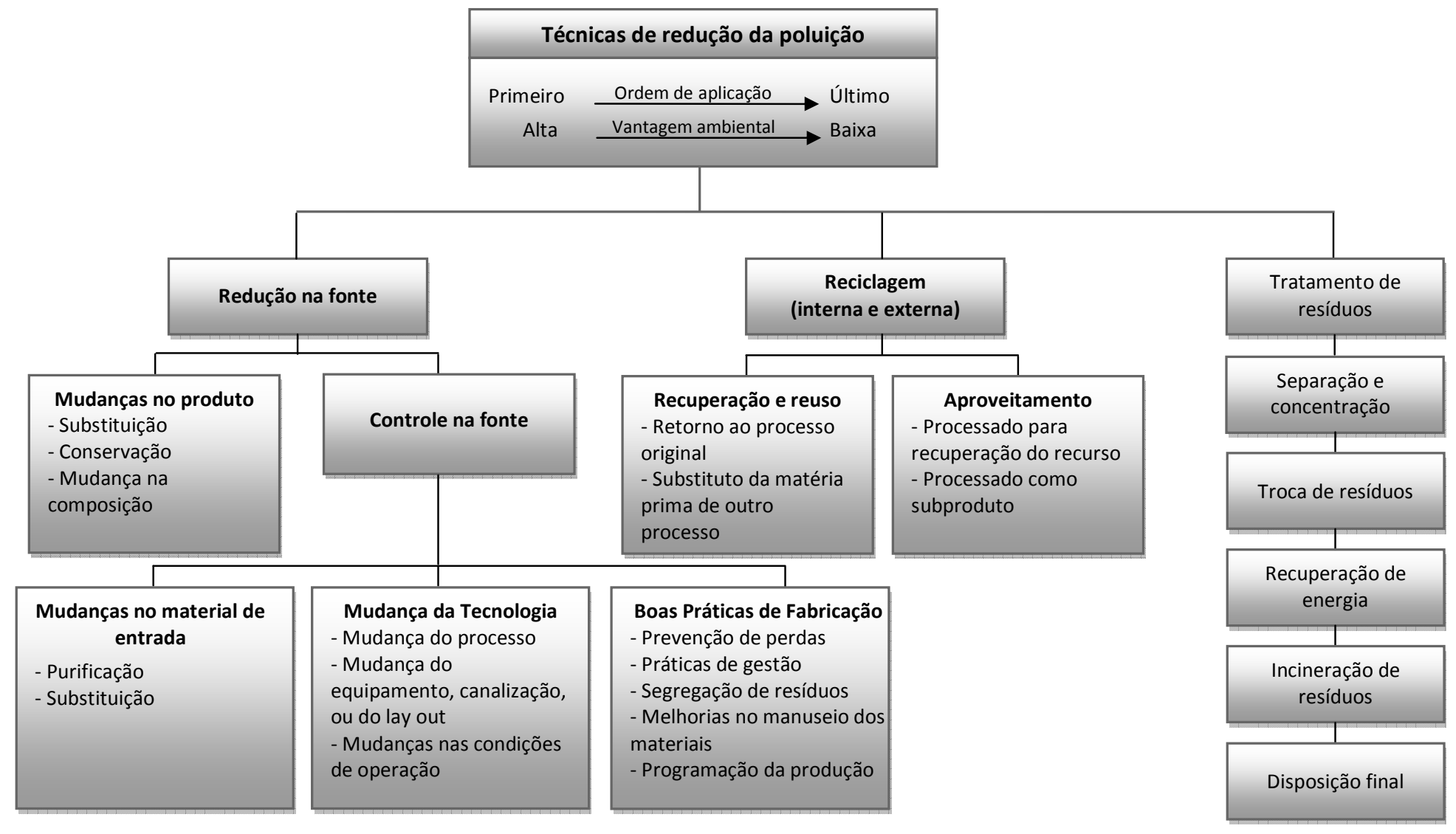

Figura 5 - Técnicas de redução da poluição.

Fonte: Adaptado de LaGrega, Buckingham e Evans, 1994, p. 356. 
Segundo Rocca (1993), a redução na fonte e a reciclagem são estratégias para a minimização de resíduos, sendo importantes no gerenciamento de resíduos por se basearem na adoção de técnicas que possibilitem a redução de volume e/ou toxicidade dos resíduos e, conseqüentemente, de sua carga poluidora.

Conforme pode ser observado na Figura 5 a prioridade na adoção destas estratégias deve ser primeiro a redução na fonte com mudanças no produto e/ou controle na fonte, depois a reciclagem e finalmente o tratamento até a destinação final dos resíduos, para aqueles que não podem ser evitados. Esta sequência de prioridades apresenta maiores vantagens ambientais, baseando-se nos mesmos princípios apresentados anteriormente na hierarquia de gerenciamento (Figura 4).

$\mathrm{Na}$ literatura muitos termos têm sido usados para descrever as práticas de gestão preventivas, como: prevenção à poluição, produção mais limpa, minimização de resíduos, redução de resíduos, redução na fonte, reciclagem, reuso, entre outros.

Este capítulo irá apresentar os conceitos de produção mais limpa, prevenção à poluição, reuso e reciclagem, mais relevantes para a presente pesquisa. Antes, porém, será apresentada a classificação dos resíduos conforme as normas existentes.

\subsection{Classificação dos resíduos sólidos}

Os resíduos sólidos industriais apresentam características diversificadas, dependendo do processo de manufatura que os originou, tornando seu gerenciamento complexo.

Para que os resíduos sejam gerenciados adequadamente os mesmos são divididos em classes conforme seus riscos potenciais ao meio ambiente e à saúde pública.

A classificação de resíduos envolve a identificação do processo ou atividade que lhes deu origem e de seus constituintes e características e a comparação destes constituintes com listagens de resíduos e substâncias cujo impacto à saúde e ao meio ambiente é conhecido (ABNT, 2004a, p. 2).

A classificação dos resíduos sólidos foi padronizada pela ABNT, que editou o seguinte conjunto de normas:

- NBR 10.004 - Resíduos Sólidos - Classificação 
- NBR 10.005 - Lixiviação de Resíduos - Procedimento

- NBR 10.006 - Solubilização de Resíduos - Procedimento

- NBR 10.007 - Amostragem de Resíduos - Procedimento

A NBR 10.004 classifica os resíduos quanto aos seus riscos potenciais ao meio ambiente e à saúde pública, agrupando-os em três classes:

- Resíduos Classe I - Perigosos: são aqueles resíduos ou misturas dos mesmos, que apresentam periculosidade, ou qualquer característica de inflamabilidade, corrosividade, reatividade, toxicidade, patogenicidade ${ }^{15}$ ou ainda que constem nos anexos $A$ (resíduos perigosos de fontes não específicas) ou B (resíduos perigosos de fontes específicas) da Norma. Estes resíduos podem apresentar risco a saúde pública, provocando ou contribuindo para um aumento da mortalidade ou incidência de doenças e/ou apresentar efeitos adversos ao meio ambiente, quando manuseados ou dispostos de maneira inadequada.

- Resíduos Classe II - Não Perigosos, divididos em:

$\Leftrightarrow$ Resíduos Classe II A - Não Inertes: aqueles que não se enquadram nas classificações de resíduos Classe I ou Classe II B nos termos da Norma. Estes resíduos podem ter propriedades, tais como: biodegradabilidade, combustibilidade ou solubilidade em água.

$\Leftrightarrow$ Resíduos Classe II B - Inertes: quaisquer resíduos que, quando amostrados de uma forma representativa, segundo a ABNT NBR 10.007, e submetidos a um contato dinâmico e estático com água destilada ou deionizada, à temperatura ambiente, conforme ABNT NBR 10.006, não tiverem nenhum de seus constituintes solubilizados a concentrações superiores aos padrões de potabilidade de água, excetuando-se aspecto, cor, turbidez, dureza e sabor. "Como exemplo destes materiais, pode-se citar: rochas, tijolos, vidros e certos plásticos e borrachas que não são facilmente decompostos" (ROCCA, 1993, p. 14).

A NBR 10.004 ainda apresenta o código de identificação para diversos resíduos, principalmente os tóxicos. Além dos anexos $A$ e $B$, já citados, esta Norma conta com mais os seguintes anexos:

- Anexo C - Substâncias que conferem periculosidade aos resíduos;

\footnotetext{
${ }^{15}$ Para definição dos termos (periculosidade, inflamabilidade, corrosividade, reatividade, toxidade e patogenicidade) consultar Glossário.
} 
- Anexo D - Substâncias agudamente tóxicas;

- Anexo E - Substâncias tóxicas;

- Anexo F - Concentração - Limite máximo no extrato obtido no ensaio de lixiviação;

- Anexo G - Padrões para o ensaio de solubilização;

- Anexo H-Codificação de alguns resíduos classificados como não perigosos.

De forma geral, os resíduos são classificados em função das suas propriedades físicas, químicas ou infecto-contagiosas e com base na identificação de contaminantes presentes em sua massa (ROCCA, 1993).

Para a classificação dos resíduos é impressindível um conhecimento prévio do processo industrial, para identificação das substâncias presentes e verificação da sua periculosidade. Quando um resíduo tem origem desconhecida, o trabalho para classificá-lo torna-se complexo. Nestes momentos, a experiência e o bom senso do profissional serão fundamentais para a definição das substâncias que deverão ser pesquisadas.

A classificação do resíduo ainda depende da sua correta amostragem. Segundo Rocca (1993, p. 15) "a amostragem é o conjunto das operações que conduzem à obtenção de uma pequena porção realmente representativa da composição média do todo."

Os requisitos para a amostragem de resíduos estão especificados na NBR 10.007. Antes da realização da coleta deve ser estabelecido o plano de amostragem, que deve incluir:

[...] avaliação do local, forma de armazenamento, pontos de amostragem, tipos de amostradores, número de amostras a serem coletadas, seus volumes, seus tipos (simples ou compostos), número e tipos dos frascos de coleta, métodos de preservação e tempo de armazenagem, assim como os tipos de equipamentos de proteção a serem utilizados durante a coleta (ABNT, 2004b).

O fluxograma a seguir apresenta a metodologia a ser adotada para caracterização e classificação dos resíduos sólidos, de acordo com a NBR 10.004. 


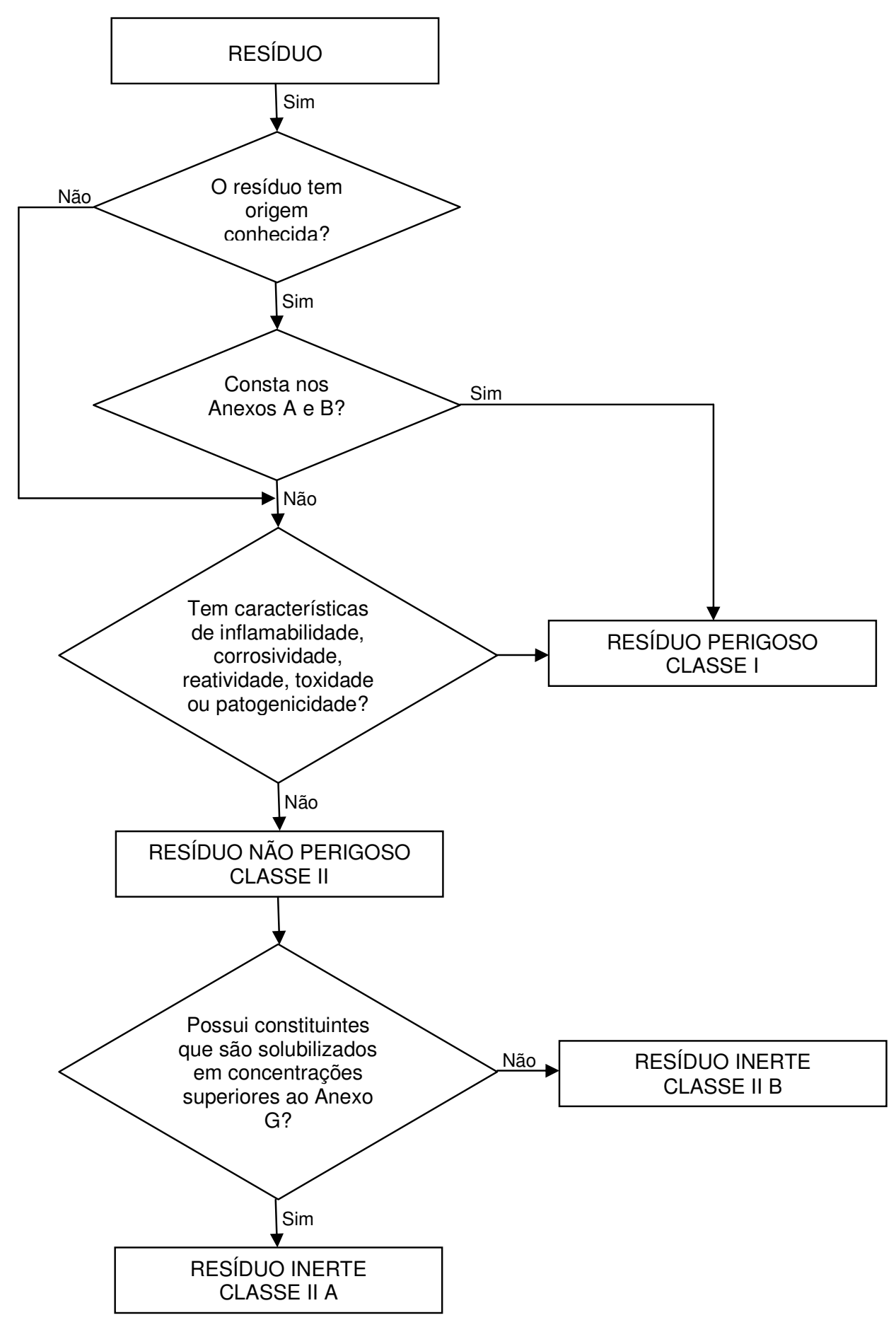

Figura 6 - Caracterização e classificação dos resíduos sólidos. Fonte: ABNT, 2004a, p. VI.

Como apresentado no fluxograma e mencionado anteriormente, o conhecimento da origem do resíduo facilitará no processo de classificação. A partir desta classificação deverão ser tomadas as decisões técnicas e econômicas para 
todas as fases do gerenciamento dos resíduos sólidos industriais, desde o seu manuseio, acondicionamento, armazenamento, coleta, transporte e destinação final. Maiores detalhes quando ao manuseio dos resíduos sólidos são apresentados no capítulo 4.

\subsection{Produção mais limpa}

O termo Produção mais Limpa $(\mathrm{P}+\mathrm{L})$ foi definido em 1990 pelo Programa das Nações Unidas para o Meio Ambiente (PNUMA), ou como é conhecido em inglês United Nations Environment Programme (UNEP), como a aplicação continua de uma estratégia ambiental integrada aos processos, produtos e serviços para aumentar a eficiência e reduzir os riscos ao homem e ao meio ambiente (UNEP, 2010).

Segundo o Centro Nacional de Tecnologias Limpas (CNTL/SENAI-RS),

Produção mais Limpa é a aplicação de uma estratégia técnica, econômica e ambiental integrada aos processos e produtos, a fim de aumentar a eficiência no uso de matérias-primas, água e energia, através da não geração, minimização ou reciclagem dos resíduos e emissões geradas, com benefícios ambientais, de saúde ocupacional e econômicos (CNTL, 2003a, p. 10).

A Agenda 21, adotada na Rio-92, claramente referiu-se a Produção mais Limpa como o caminho para reconciliar o crescimento econômico com a proteção ambiental. Mais amplamente, reconheceu a necessidade de mudar os padrões de produção e consumo (UNEP, 2002a).

De certa forma a produção mais limpa não é um conceito novo, e sim a extensão lógica do desejo de conservar os materiais e reduzir os resíduos. Para isso torna-se necessária a busca por caminhos que resultem no aumento da eficiência na conversão dos materiais, redução do consumo de recursos naturais, redução na produção de resíduos, e o mais importante, redução do risco ao meio ambiente.

Segundo o PNUMA (2005) esta estratégia aplica-se a:

- Processos produtivos: inclui conservação de recursos naturais e energia, eliminação de matérias-primas tóxicas e redução da quantidade e da toxicidade dos resíduos e emissões;

- Produtos: envolve a redução dos impactos negativos ao longo do ciclo de vida de um produto, desde a extração de matérias-primas até sua disposição final; 
- Serviços: estratégia para incorporação de considerações ambientais no planejamento e entrega de serviços.

Esta nova abordagem de gerenciamento surgiu para modificar os métodos convencionais que tinham como foco o final do processo, ou as chamadas tecnologias de fim-de-tubo (end-of-pipe).

$\mathrm{Na}$ abordagem tradicional, as primeiras ações tomadas são geralmente a disposição dos resíduos ou o seu tratamento, que representam um potencial menor para a solução do problema ambiental, além de serem mais caras no longo prazo, por apenas agregarem novos custos ao processo produtivo (CNTL, 2003a, p. 12).

As tecnologias de fim-de-tubo têm o objetivo de tratar a poluição resultante de um processo produtivo, com a incorporação de novos equipamentos e instalações nos pontos de descarga dos poluentes (BARBIERI ${ }^{16}, 2004$ apud OURA e SOUZA, 2007). Trata-se, portanto, de adicionar a tecnologia ao final dos processos usuais com o objetivo de reduzir as emissões nocivas ao meio ambiente (MOORS; MULDER; VERGRAGT, 2005), para assim atender as regulamentações da legislação ambiental.

A abordagem lógica, pelo contrário, privilegia as soluções voltadas para a prevenção e minimização, sugerindo que as empresas atuem na fonte geradora, buscando alternativas para o desenvolvimento de um processo eco-eficiente, resultando na não geração dos resíduos, redução ou reciclagem interna e externa (CNTL, 2003a, p. 12).

O quadro a seguir apresenta as diferenças básicas entre as técnicas de fim de tubo e a produção mais limpa e a Figura 7 o foco de cada uma destas técnicas, incluindo as ações da P+L.

Quadro 2 - Diferenças entre as técnicas de fim de tubo e produção mais limpa.

\begin{tabular}{|c|c|}
\hline Técnica de Fim de Tubo & Produção Mais Limpa \\
\hline Pretende reação. & Pretende ação. \\
\hline $\begin{array}{c}\text { Os resíduos, os efluentes e as emissões são } \\
\text { controlados através de equipamentos de } \\
\text { tratamento. }\end{array}$ & $\begin{array}{c}\text { Prevenção da geração de resíduos, efluentes e } \\
\text { emissões na fonte. Procurar evitar matérias- } \\
\text { primas potencialmente tóxicas. }\end{array}$ \\
\hline $\begin{array}{l}\text { Proteção ambiental é um assunto para } \\
\text { especialistas competentes. }\end{array}$ & Proteção ambiental é tarefa para todos. \\
\hline $\begin{array}{l}\text { A proteção ambiental atua depois do } \\
\text { desenvolvimento dos processos e produtos. }\end{array}$ & $\begin{array}{c}\text { A proteção ambiental atua como uma parte } \\
\text { integrante do design do produto e da engenharia } \\
\text { de processo. }\end{array}$ \\
\hline $\begin{array}{l}\text { Os problemas ambientais são resolvidos a partir } \\
\text { de um ponto de vista tecnológico. }\end{array}$ & $\begin{array}{c}\text { Os problemas ambientais são resolvidos em } \\
\text { todos os níveis e em todos os campos. }\end{array}$ \\
\hline $\begin{array}{l}\text { Não tem a preocupação com o uso eficiente de } \\
\text { matérias-primas, água e energia. }\end{array}$ & $\begin{array}{l}\begin{array}{l}\text { Uso eficiente de matérias-primas, água e } \\
\text { energia. }\end{array} \\
\end{array}$ \\
\hline Leva a custos adicionais. & Ajuda a reduzir custos. \\
\hline
\end{tabular}

Fonte: CNTL, 2003a, p. 12.

${ }^{16}$ BARBIERI, J. C. Gestão ambiental empresarial: conceitos, modelos e instrumentos. São Paulo: Saraiva, 2004. 


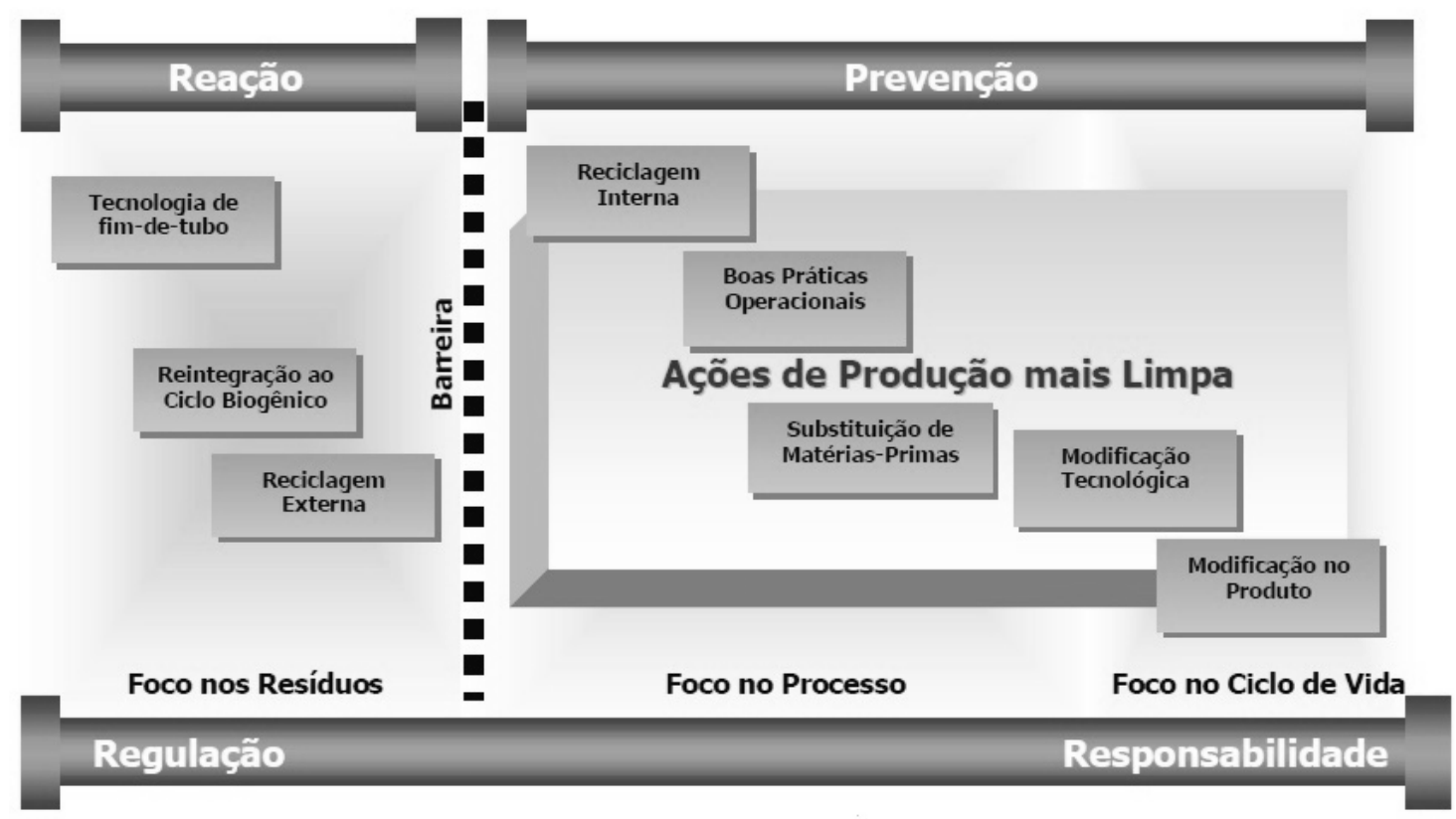

Figura 7 - Ações reativas e preventivas no gerenciamento empresarial. Fonte: CNTL, 2003a, p. 13.

Apesar da produção mais limpa ser mais interessante do ponto de vista ambiental e econômico, na prática, frente às restrições de capital e às pressões dos órgãos ambientais e da sociedade, as empresas têm adotado estratégias ambientais corretivas (tratamento da poluição ao final do processo) no lugar de estratégias preventivas, como é o caso da Produção mais Limpa.

\subsection{Prevenção à poluição}

Outro termo bastante utilizado e encontrado na literatura e que tem seu foco na eliminação das causas da poluição, ao invés de simplesmente tratar os sintomas, é a prevenção à poluição (P2). Esta estratégia é conceituada pela Agência Ambiental do Canadá como: a utilização de processos, práticas, materiais, produtos, substâncias ou energia que evitem ou minimizem a geração de poluentes e resíduos, e reduzem o risco geral à saúde humana e ao meio ambiente (EC, 2010).

A prevenção à poluição, como prática de gerenciamento ambiental, surgiu no início dos anos 90, como um método alternativo para o controle da poluição através 
da redução da quantidade e da periculosidade dos resíduos lançados no meio ambiente.

Segundo a Companhia Ambiental do Estado de São Paulo (CETESB),

A P2 refere-se a qualquer prática, processo, técnica e tecnologia que visem
a redução ou eliminação em volume, concentração e toxicidade dos
poluentes na fonte geradora. Inclui também modificações nos
equipamentos, processos ou procedimentos, reformulação ou
replanejamento de produtos, substituição de matérias-primas, eliminação de
substâncias tóxicas, melhorias nos gerenciamentos administrativos e
técnicos da empresa e otimização do uso das matérias-primas, energia,
água e outros recursos naturais (CETESB, 2002, p.3).

Pode-se notar que tanto a prevenção à poluição como a produção mais limpa buscam a redução dos resíduos na fonte, através de modificações na matéria-prima, nas tecnologias e procedimentos operacionais.

No entanto, não se consideram como redução de resíduos, as ações que ocorrem fora da atividade produtiva, incluindo a reciclagem ou o tratamento, pois são tomadas depois que os resíduos são gerados. Assim como, as ações que meramente concentram o seu conteúdo para reduzir o seu volume ou diluí-lo, para diminuir o grau de periculosidade, no caso dos resíduos perigosos.

Muitas vezes os termos prevenção à poluição e produção mais limpa são utilizados como sinônimos. A distinção entre os dois tende a ser geográfica - 0 primeiro termo é mais usado na América do Norte, enquanto o segundo é utilizado em outras partes do mundo (CNTL, 2003a). Neste trabalho será utilizado mais frequentemente o termo produção mais limpa.

\subsection{Reciclagem, reuso e recuperação}

A reciclagem é definida como o processo de reaproveitamento dos resíduos sólidos, em que os seus componentes são separados, transformados e recuperados, envolvendo economia de matérias-primas e energia, combate ao desperdício, redução da poluição ambiental e valorização dos resíduos, com mudança de concepção em relação aos mesmos (PNUD ${ }^{17}$, 1998, apud GALBIATI, 2010).

\footnotetext{
17 PNUD. Educação Ambiental na Escola e na Comunidade. Brasília: Programa das Nações
} Unidas para o Desenvolvimento/ONU, 1998. 
Para Bidone (2001, p. 44) "a reciclagem é o processo pelo qual os resíduos retornam ao sistema produtivo como matéria-prima."

De acordo com Lund (1993) a reciclagem ocorre por três razões básicas: razões altruísticas, imperativos econômicos e considerações legais. No primeiro caso, proteger o ambiente e conservar os recursos naturais tornou-se de interesse geral de todos. Segundo, os custos para a disposição adequada de resíduos, que eram evitados, aumentou para um nível que, quando combinados com outros associados a reciclagem, agora mostram fazer sentido reciclar muitos materiais. Finalmente, em reposta a demanda pública e a crescente falta de alternativas de disposição final de resíduos, o governo está requerendo a reciclagem e prevendo uma ampla variedade de sanções e incentivos econômicos a fim de incentivar a reciclagem.

Do ponto de vista ambiental a reciclagem diminui a quantidade de resíduos a serem dispostos no ambiente, aumentando a vida útil dos aterros sanitários e industriais, além de contribuir para a conservação dos recursos naturais, pois minimiza sua utilização.

Do ponto de vista econômico, proporciona a redução do custo de gerenciamento dos resíduos, com menores investimentos em transporte, armazenamento e em instalações de tratamento e disposição final, ainda promovendo a criação de empregos.

Mesmo assim não se deve deixar de mencionar que a reciclagem deve ser adotada quando já estiverem esgotadas as possibilidades de redução dos resíduos na fonte geradora, que pode ser obtida com o uso das técnicas de produção mais limpa ou prevenção da poluição já mencionadas anteriormente.

Já a reutilização ou reuso consiste no aproveitamento do material nas condições em que é descartado, submetendo-o a pouco ou nenhum tratamento, ou seja, não há nenhuma transformação. Dependendo do material é realizada apenas a operação de limpeza e colocação de etiquetas, como é o caso de caixas, tambores e garrafas de vidro.

Existe ainda o termo recuperado, quando o material foi reprocessado a fim de obter-se um produto novamente útil, ou passou por um tratamento para que fosse possível a sua regeneração.

Todas essas estratégias requerem a segregação dos materiais na fonte geradora e a definição de pontos de coleta e estocagem. Em um processo produtivo 
é grande a variedade de resíduos passíveis de reutilização, recuperação e reciclagem. Algumas estratégias propostas pela US EPA ${ }^{18}$ (1993, apud SANTOS, 2005), são a seguir sumarizadas:

- Reutilizar pellets de isopor, plásticos bolha, caixas de papelão e outros materiais usados para proteção de produtos, ou doar estes materiais a outras organizações;

- Promover o retorno de embalagens (pellets, tambores, bombonas, etc), aos fornecedores para reutilização;

- Utilizar o papel usado picotado como material para proteger produtos na embalagem, em substituição à plástico bolha e pellets de isopor;

- Promover campanhas educativas entre os funcionários;

- Contatar empresas externas para a venda dos materiais;

- Promover campanhas de doação de materiais, que não possam ser comercializados, para instituições assistenciais;

- Participar de programas municipais de coleta de materiais;

- Participar de programas de troca de resíduos, as chamadas bolsas de resíduos, onde o material que é considerado resíduo para uma determinada empresa, pode servir como matéria-prima para outra.

Apesar de todos os benefícios advindos da recuperação e da reciclagem, antes de seu emprego deve ser realizado um estudo de viabilidade econômica, onde deverão ser considerados os seguintes aspectos:

- Proximidade do local de geração ao de recuperação do resíduo;

- Volume do resíduo gerado disponível para o reprocessamento;

- Custos das etapas de gerenciamento antes do reprocessamento, incluindo separação, coleta, armazenamento e transporte dos resíduos;

- Existência de demanda para o produto resultante da reciclagem;

- Existência de tecnologia para a transformação do resíduo;

- Custo do processamento e transformação do resíduo em um novo produto, sem prejuízos de suas características e aplicabilidade.

Segundo Rocca (1993, p. 27) "para incentivar as atividades de reciclagem, têm sido criados em muitos países, inclusive no Brasil, sistemas de trocas de informações através de uma publicação denominada 'Bolsa de Resíduos'”.

\footnotetext{
${ }^{18}$ UNITED STATES ENVIRONMENTAL AGENCY-US EPA. Business Guide for Reducing Solid Waste. Washington: EPA/530-K-92-004, 1993.
} 
As Bolsas de Resíduos são serviços de informações em nível nacional e internacional, concebidas com a finalidade de identificar mercados para os resíduos gerados nas operações industriais e estimular seu reaproveitamento de forma racional e econômica. As Bolsas de Resíduos servem como guia para promoção de oportunidades de negócios, a fim de propiciar novas alternativas de mercado e ocupar a capacidade ociosa eventualmente existente em alguns campos dos processos industriais de produção (JÚNIOR, CASTRO \& DELFORGE, 2004).

Existem diversos sites na Internet, na grande maioria gerenciados pela Federação das Indústrias dos Estados, onde os interessados em vender ou doar algum material anunciam na Bolsa indicando nome, composição química e quantidade do resíduo. Os interessados em comprar entram em contato através da Bolsa ou diretamente com o vendedor ou doador e acertam os aspectos econômicos e operacionais da transação. Do mesmo modo, se algum empresário deseja receber ou comprar determinado resíduo ele também pode utilizar-se da Bolsa com esse objetivo.

Pode-se notar, portanto, que as Bolsas de resíduos têm por finalidade facilitar a troca de informações entre produtores de resíduos e os potenciais compradores, não interferindo na transação entre eles.

No quadro a seguir é apresentado o endereço eletrônico de algumas Bolsas de resíduos, neste caso, todas vinculadas a Federação das Indústrias dos Estados indicados.

Quadro 3 - Endereço na Internet de algumas Bolsas de resíduos no Brasil.

\begin{tabular}{|l|c|l|}
\hline \multicolumn{1}{|c|}{ Denominação } & Estado & \multicolumn{1}{c|}{ Endereço na Internet } \\
\hline $\begin{array}{l}\text { Bolsa de resíduos - } \\
\text { negócios e meio } \\
\text { ambiente }\end{array}$ & São Paulo & http://apps.fiesp.com.br/bolsaresiduos/ \\
\hline Bolsa de resíduos & Rio de Janeiro & $\begin{array}{l}\text { http://www.firjan.org.br/data/pages/2C908CE921D61 } \\
\text { B940121E97B6E7517BB.htm }\end{array}$ \\
\hline $\begin{array}{l}\text { Bolsa de resíduos e } \\
\text { subprodutos }\end{array}$ & Bahia & $\begin{array}{l}\text { http://200.223.40.100/bolsa/bolsa.nsf/inicial?OpenFo } \\
\text { rm }\end{array}$ \\
\hline $\begin{array}{l}\text { Sistema Integrado } \\
\text { de Bolsa de } \\
\text { resíduos }\end{array}$ & $\begin{array}{l}\text { Pará, Goiás, Paraná, } \\
\text { Pernambuco, Sergipe, } \\
\text { Bahia, Espírito Santo e } \\
\text { Minas Gerais }\end{array}$ & http://www.sibr.com.br/sibr/index_cni.jsp \\
\hline $\begin{array}{l}\text { Bolsa de resíduos e } \\
\text { negócios }\end{array}$ & \multicolumn{1}{c}{ Ceará } & http://www.fiec.org.br/iel/bolsaderesiduos/index.asp \\
\hline $\begin{array}{l}\text { Bolsa de resíduos } \\
\text { Sistema FIESC }\end{array}$ & Santa Catarina & $\mathrm{http://www.brfiesc.com.br/home/index.php}$ \\
\hline Bolsa de resíduos & Mato Grosso do Sul & $\mathrm{http://www.fiems.org.br/index.php?m=residuos}$ \\
\hline
\end{tabular}




\section{MANUSEIO DOS RESÍDUOS}

Os resíduos que não podem ser eliminados no processo de produção devem ser adequadamente manuseados para que não haja o comprometimento da saúde humana ou danos ao meio ambiente. Este processo deve envolver desde o treinamento dos funcionários que irão ter o primeiro contato com os resíduos até a disposição final. Entre estas etapas os resíduos devem ainda ser segregados, acondicionados, armazenados, coletados, transportados e, quando necessário, tratados.

O correto manuseio dos resíduos, apesar de gerar custos, não pode ser desconsiderado, sendo inclusive menos oneroso que a recuperação dos recursos naturais contaminados (CNTL, 2003b).

Não se deve deixar de notar que mesmo pós-processo industrial a redução da geração dos resíduos ainda pode ser alcançada. O cumprimento das normas e adoção de técnicas adequadas nas etapas de gerenciamento pode garantir, por exemplo, a redução da geração de resíduos perigosos, quando se realiza a segregação dos resíduos na fonte, evitando que resíduos classe II sejam misturados com classe I.

\subsection{Treinamento de pessoal}

O primeiro contato dos resíduos gerados nas indústrias é com os operadores e funcionários da empresa. Desta forma, estes devem ser treinados para manusear os resíduos de forma adequada evitando riscos a sua própria saúde. Segundo o CNTL (2003b) o treinamento básico deve conter:

- Informações quanto às características e os riscos inerentes ao trato de cada tipo de resíduo;

- Orientação quanto à execução das tarefas de coleta, transporte e armazenamento;

- Utilização adequada de Equipamentos de Proteção Individual (EPI's) necessários às suas atividades, e 
- Procedimentos de emergência em caso de contato ou contaminação com o resíduo, tanto individual, quanto ambiental.

Apesar da importância deste treinamento, Rocca (1993, p. 31) afirma que "a movimentação dos resíduos nas indústrias, com raras exceções, é realizada por pessoal não qualificado". Sem a informação necessária, os operadores acabam se expondo a riscos, que muitas vezes não podem ser identificados no momento do contato, pois o resíduo pode não apresentar efeitos imediatos ou visíveis, como uma intoxicação aguda ou uma queimadura, mas com o contato prolongado pode resultar em distúrbios irreversíveis no organismo e mesmo danos genéticos aos seus descendentes.

\subsection{Segregação}

A segregação de resíduos nas indústrias tem como objetivo básico evitar a mistura de resíduos incompatíveis, contribuir para o aumento da qualidade dos resíduos que possam ser recuperados ou reciclados e diminuir o volume de resíduos perigosos ou especiais a serem tratados ou dispostos (ROCCA, 1993).

Sendo assim, a segregação possibilitará que os resíduos recicláveis não sejam contaminados ou tenham sua qualidade comprometida, podendo então retornar a cadeia produtiva para fabricação de novos produtos.

Para o empresário a venda de resíduos recicláveis poderá se tornar fonte adicional de renda, além de contribuir com a redução dos custos de disposição final. Rocca (1993) aponta que este ganho, aparentemente, pode não ser interessante quando a quantidade de resíduos gerados é pequena, mas ao se computar os custos de transporte e disposição final, provavelmente, esta idéia poderá se modificar.

Para facilitar o processo de separação dos resíduos pode-se utilizar o código de cores apresentado pela Resolução CONAMA n. ${ }^{\circ}$ 275/2001:

- Azul - papel/papelão

- Vermelho - plástico;

- Verde-vidro;

- Amarelo - metal; 
- Preto - madeira;

- Laranja - resíduos perigosos;

- Branco - resíduos ambulatoriais e de serviços de saúde;

- Roxo - resíduos radioativo;

- Marrom - resíduos orgânicos;

- Cinza - resíduo geral não reciclável ou misturado, ou contaminado não passível de separação.

Este código de cores deverá ser utilizado nos containeres e locais de armazenamento dos resíduos, sendo que os operários devem ser devidamente instruídos quanto ao significado de cada cor e os riscos associados no manuseio destes materiais. Desta forma, além de facilitar a segregação dos resíduos o código de cores serve como alerta para os operários evitando-se assim acidentes no manuseio dos resíduos.

Outra razão para se realizar a segregação dos resíduos apontada por Rocca (1993) é evitar a mistura de resíduos incompatíveis.

\begin{abstract}
A mistura de dois ou mais resíduos incompatíveis pode ocasionar reações indesejáveis ou incontroláveis que resultem em conseqüências adversas ao homem, ao meio ambiente, aos equipamentos e mesmo à própria instalação industrial. A extensão dos danos dependerá das características dos resíduos, das quantidades envolvidas, do local de estocagem e do tipo de reação (ROCCA, 1993, p. 32).
\end{abstract}

Segundo o mesmo autor os fenômenos mais comuns que podem ocorrer decorrentes da mistura de resíduos incompatíveis são: geração de calor, fogo ou explosão; geração de fumos os gases tóxicos; geração de gases inflamáveis; volatilização de substâncias tóxicas ou inflamáveis; solubilização de substâncias tóxicas ou polimerização violenta.

Desta forma, para que isso seja evitado os profissionais responsáveis pela elaboração de um programa de estocagem, transporte ou de disposição de resíduos devem consultar o quadro de incompatibilidade de resíduos apresentado a seguir. 
Quadro 4-Incompatibilidade de resíduos.

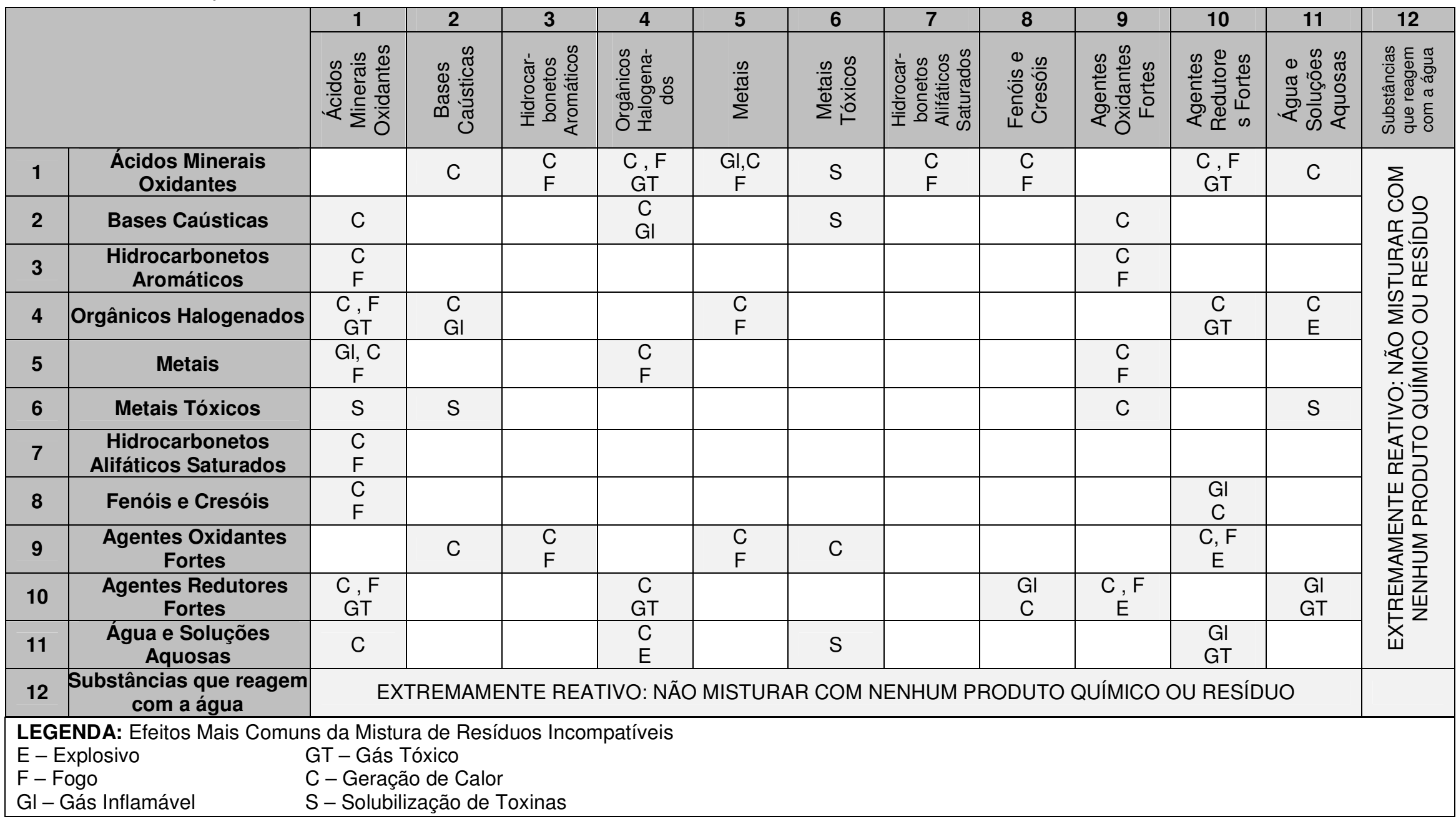

Fonte: Adaptado de Rocca, 1993, p. 33. 


\subsection{Acondicionamento}

Os resíduos gerados nas empresas devem ser acondicionados em recipientes adequados às características dos resíduos para evitar riscos ao trabalhador e ao meio ambiente. A escolha do tipo de recipiente dependerá das características do resíduo, das quantidades geradas, periodicidade, do tipo de transporte, da necessidade ou não de tratamento e da forma de disposição a ser adotada. Desta forma sua escolha deve observar alguns critérios mínimos (ROCCA, 1993):

- ser construído com material compatível aos resíduos;

- ser estanque, evitando assim possíveis vazamentos;

- apresentar resistência física a pequenos choques que podem ocorrer durante o seu manuseio;

- ser durável;

- ser compatível com o equipamento de transporte, em termos de forma, volume e peso.

Normalmente são utilizados dois tipos de recipientes: 0 de pequena capacidade, instalado próximo aos pontos de geração, e o de grande capacidade instalado na área de armazenagem da indústria.

Segundo Monteiro (2001), as formas mais usuais de se acondicionar os resíduos sólidos industriais são:

- tambores metálicos de 200 litros para resíduos sólidos sem características corrosivas;

- bombonas plásticas de 200 ou 300 litros para resíduos sólidos com características corrosivas ou semi-sólidos em geral;

- big-bags plásticos, que são sacos, normalmente de polipropileno trançado, de grande capacidade de armazenamento, quase sempre superior a $1 \mathrm{~m}^{3}$;

- contêineres plásticos, padronizados nos volumes de 120, 240, 360, 750, 1.100 e 1.600 litros, para resíduos que permitem o retorno da embalagem;

- caixas de papelão, de porte médio, até 50 litros, para resíduos a serem incinerados. 


\subsection{Armazenamento}

O armazenamento de resíduos é definido pela NBR 12.235/92 como a "Contenção temporária de resíduos, em área autorizada pelo órgão de controle ambiental, à espera de reciclagem, recuperação, tratamento ou disposição final adequada, desde que atenda às condições básicas de segurança".

O armazenamento dos resíduos deverá atender a Portaria Minter n. ${ }^{0} 124$, de 20 de agosto de 1980 e ser executado conforme as condições estabelecidas nas normas:

- NBR 12.235/1992 - Armazenamento de resíduos perigosos;

- NBR 11.174/1990 - Armazenamento de resíduos não inertes e inertes;

- NB 98 - Armazenamento e manuseio de líquidos inflamáveis e combustíveis

A Portaria Minter n. ${ }^{0} 124 / 80$ estabelece normas para a localização das estruturas de armazenamento de substâncias capazes de causar poluição hídrica. De acordo com esta regulamentação estas estruturas devem ser instaladas a uma distância mínima de 200 (duzentos) metros de coleções hídricas ou cursos d'água.

Além disso, todo depósito projetado ou construído acima do nível do solo, para receber líquidos potencialmente poluentes, deverá ser protegido, dentro das necessárias normas de segurança devendo ser construídos, para tanto, tanques, amuradas, silos subterrâneos, barreiras ou outros dispositivos de contenção, com a capacidade e a finalidade de receber e guardar os derrames de líquidos poluentes, provenientes dos processos produtivos ou de armazenagem.

Segundo o CNTL (2003b) na escolha da área onde o resíduo vai ficar depositado temporariamente devem ser observados os seguintes itens:

- o local deve ser projetado para que o risco de contaminação ambiental seja mínimo;

- deve ser de fácil acesso para os equipamentos de transporte;

- deve ter o acesso limitado e sinalização;

- os resíduos devem estar devidamente identificados e dispostos em áreas separadas;

- o piso deve ser impermeabilizado e com drenagens para a Estação de Tratamento de Efluentes (ETE); 
- os resíduos de diferentes classificações não devem ser armazenados próximos;

- o local deve ser coberto, dependendo do tipo de resíduo estocado;

- o local deve ser ligeiramente afastado de áreas administrativas. Deverá ser controlada a direção predominante dos ventos para evitar problemas de odor.

- a Instalação deverá possuir equipamentos de segurança e de proteção individual compatível com os resíduos e com as possíveis emergências.

Ainda quanto a seleção do local de armazenamento, segundo a norma NBR 11.174/90, devem ser considerados os seguintes fatores:

- uso do solo;

- topografia;

- geologia;

- recursos hídricos;

- acesso;

- área disponível;

- meteorologia.

A norma NBR 12.235 estabelece alguns critérios que devem ser seguidos para o armazenamento de resíduos perigosos em contêineres, tambores, tanques e a granel, conforme apresentado no Quadro 5, a seguir. 
Quadro 5 - Critérios para o armazenamento de resíduos perigosos.

\begin{tabular}{|c|c|}
\hline $\begin{array}{c}\text { Forma de } \\
\text { armazenamento }\end{array}$ & Condições gerais e critérios de armazenamento \\
\hline $\begin{array}{c}\text { Contêineres e } \\
\text { tambores }\end{array}$ & $\begin{array}{l}\text { - A área de armazenamento deve ser coberta e ventilada. } \\
\text { - Os recipientes devem ser colocados sobre base de concreto ou outro material } \\
\text { impermeabilizante. } \\
\text { - A área deve possuir sistema de drenagem e captação de líquidos } \\
\text { contaminados, para posterior tratamento. } \\
\text { - Os recipientes devem estar rotulados para rápida identificação e apresentar } \\
\text { boa condição de uso (sem ferrugem e defeito estrutural). } \\
\text { - Os contêineres e tambores devem ser de material compatível ou possuir } \\
\text { revestimento ou impermeabilização. } \\
\text { - Os recipientes devem ser mantidos fechados e quando manuseados deve ser } \\
\text { utilizado EPl's. } \\
\text { - Os contêineres e tambores devem ser dispostos de forma a possibilitar } \\
\text { inspeção visual e seguindo os critérios de compatibilidade, para prevenir } \\
\text { reações violentas por ocasião de vazamentos. }\end{array}$ \\
\hline Tanques & $\begin{array}{l}\text { - Deve-se evitar o uso de tanques enterrados e semi-enterrados, pois a } \\
\text { detecção de falhas, rupturas e vazamentos é mais difícil. } \\
\text { - Dependendo as características dos resíduos líquidos deve-se prever a } \\
\text { instalação dos seguintes acessórios: abafador de faísca, corta-chama, } \\
\text { respiradores de pressão e vácuo, válvula de alívio, válvula de segurança interna, } \\
\text { aterramento, sistema de contenção, etc. } \\
\text { - O tanque deve possuir parede resistente e, quando for fechado, controle de } \\
\text { pressão. } \\
\text { - O projeto da instalação deve incluir as fundações, o suporte estrutural, as } \\
\text { emendas ou costuras, os controles de pressão e espessura mínima da parede. } \\
\text { - No caso de armazenamento de resíduos que apresentem incompatibilidade } \\
\text { com o material do tanque, este deve ser impermeabilizado internamente e não } \\
\text { deve apresentar vazamentos, rachaduras, buracos ou outras deteriorações. } \\
\text { - Devem ser utilizados dispositivos para prevenir o transbordamento do resíduo. }\end{array}$ \\
\hline A granel & $\begin{array}{l}\text { - O resíduo deve estar protegido de precipitações que possam gerar } \\
\text { escoamento superficial ou lixiviado. } \\
\text { - Os resíduos sólidos tóxicos devem ser armazenados em sistemas totalmente } \\
\text { fechados. } \\
\text { - Não devem ser armazenados em montes os resíduos que contenham líquidos } \\
\text { livres. } \\
\text { - Os lixiviados gerados pela decomposição dos resíduos ou outras reações } \\
\text { devem ser obrigatoriamente, coletados e tratados. } \\
\text { - Deve ser previsto um sistema de contenção e/ou impermeabilização para } \\
\text { prevenir qualquer migração de componentes dos resíduos para atmosfera, para } \\
\text { o solo ou para águas superficiais e subterrâneas. Este sistema deve ser } \\
\text { construído com materiais que tenham propriedades físico-químicas apropriadas, } \\
\text { colocado sobre uma fundação ou base capaz de promover um suporte } \\
\text { adequado e instalado de forma a cobrir toda a terra circunvizinha. }\end{array}$ \\
\hline
\end{tabular}

Fonte: Elaborado a partir da NBR 12.235/92.

Mesmo adotando-se técnicas adequadas de armazenamento de resíduos os locais de estocagem são sujeitos a diversos tipos de acidentes. Segundo Rocca (1993) os acidentes mais freqüentes são os incêndios, derramamentos e vazamentos. 
Em virtude da possibilidade desses acidentes com resíduos, em especial com os de caráter perigoso, as empresas devem desenvolver um Plano de Emergência, definido como: "um conjunto de instruções e ações pré-estabelecidas a serem imediatamente adotadas em casos de acidente" (ROCCA, 1993, p. 39).

De acordo com a NBR 12.235/92 esse Plano deve conter:

- Informações de possíveis incidentes e das ações a serem tomadas;

- Indicação da pessoa que deve atuar como coordenador e seu substituto, indicando seus telefones e endereços; esta lista deve estar sempre atualizada;

- Lista de todo equipamento de segurança existente, incluindo localização, descrição do tipo e capacidade.

\subsection{Transporte}

O resíduo gerado nas empresas deve ser transportado interna e externamente. $\mathrm{O}$ transporte interno é realizado do ponto de geração do resíduo no processo industrial até os pontos de armazenamento na empresa. Este transporte deve ser realizado a partir de rotas pré-estabelecidas; os equipamentos utilizados para este fim devem ser compatíveis com o volume, peso e forma do resíduo a ser transportado; e os funcionários envolvidos nesta tarefa, devem ser adequadamente treinados.

De maneira geral, nas indústrias brasileiras é utilizado todo e qualquer equipamento disponível no momento e freqüentemente os próprios operários transportam manualmente os resíduos. São assim, utilizados para o transporte interno: carrinho de mão, empilhadeiras, caminhonetes, caminhões de carroceria aberta basculante ou não e caminhões tipo poliguindastes (ROCCA, 1993, p. 35).

O transporte externo de resíduos pode ser realizado através de três modalidades: marítima ou fluvial, ferroviária e rodoviária. O quadro a seguir apresenta as vantagens e desvantagens de cada um desses meios de transporte. 
Quadro 6 - Vantagens e Desvantagens para o transporte de resíduos de acordo com os meios de transporte.

\begin{tabular}{|c|c|c|}
\hline $\begin{array}{l}\text { Tipo de } \\
\text { transporte }\end{array}$ & Vantagem & Desvantagem \\
\hline $\begin{array}{l}\text { Marítimo } \\
\text { ou fluvial }\end{array}$ & $\begin{array}{l}\text { - Baixo custo para o transporte de } \\
\text { grandes quantidades de resíduos a granel } \\
\text { com baixo potencial poluidor e que devam } \\
\text { percorrer grandes distâncias; } \\
\text { - Econômica para grande quantidade de } \\
\text { carga de fácil manuseio; } \\
\text { - Possibilidade do transporte de cargas de } \\
\text { grandes dimensões. }\end{array}$ & $\begin{array}{l}\text { - Velocidade consideravelmente menor } \\
\text { quando comparado aos outros meios de } \\
\text { transporte; } \\
\text { - Despesas portuárias elevadas; } \\
\text { - Condições climáticas podem restringir } \\
\text { operações de carga e descarga; } \\
\text { - Necessidade de estação de transbordo } \\
\text { no porto de origem e chegada; } \\
\text { - Os acidentes comprometem área } \\
\text { significativa. }\end{array}$ \\
\hline Ferroviário & $\begin{array}{l}\text { - Econômica para grandes quantidades; } \\
\text { - Custo baixo para grandes distâncias; } \\
\text { - Rota de trânsito definida; } \\
\text { - O pessoal que opera o sistema é fixo e } \\
\text { com experiência; } \\
\text { - Sofre menor influência das condições } \\
\text { climáticas durante a carga e descarga; } \\
\text { - As ferrovias possuem Plano de } \\
\text { Emergência e sistemas de comunicação, } \\
\text { agilizando a detecção de acidentes. }\end{array}$ & $\begin{array}{l}\text { - Taxas de embarque elevadas para } \\
\text { pequenas quantidades; } \\
\text { - É necessária a contratação do } \\
\text { transporte com certa antecedência; } \\
\text { - Necessidade da existência de estação } \\
\text { de transbordo no embarque e } \\
\text { desembarque; } \\
\text { - O sistema ferroviário já deve estar } \\
\text { implantado. }\end{array}$ \\
\hline Rodoviário & $\begin{array}{l}\text { - Baixo custo para pequenas quantidades; } \\
\text { - Baixo custo para pequenas distâncias; } \\
\text { - Não necessita de sistema de transbordo } \\
\text { nos pontos de geração e descarga; } \\
\text { - O serviço pode ser contratado de } \\
\text { imediato. }\end{array}$ & $\begin{array}{l}\text { - Não é adequado para grandes } \\
\text { quantidades; } \\
\text { - Custo elevado para grandes distâncias; } \\
\text { - As rotas podem ser alteradas facilmente; } \\
\text { - Apresenta alta rotatividade de mão de } \\
\text { obra; } \\
\text { - Maiores dificuldades na comunicação de } \\
\text { acidentes. }\end{array}$ \\
\hline
\end{tabular}

Fonte: Elaborado a partir de Rocca, 1993.

A NBR 13.221/2000, que dispõem sobre o transporte terrestre de resíduos, apresenta os requisitos gerais para esta atividade:

- O transporte deve ser feito por meio de equipamentos adequados, obedecendo às regulamentações pertinentes;

- O estado de conservação do equipamento de transporte deve ser tal que, durante o transporte, não permita o vazamento ou derramamento do resíduo;

- O resíduo, durante o transporte, deve estar protegido de intempéries, assim como deve estar devidamente acondicionado para evitar o seu espalhamento na via pública ou via férrea;

- Os resíduos não podem ser transportados juntamente com alimentos, medicamentos ou produtos destinados ao uso e/ou consumo humano ou animal ou com embalagens destinadas a estes fins;

- O transporte de resíduos deve atender à legislação ambiental específica, quando existente, bem como deve ser acompanhado de documento de 
controle ambiental previsto pelo órgão competente, devendo informar o tipo de acondicionamento;

- A descontaminação dos equipamentos de transporte deve ser de responsabilidade do gerador e deve ser realizada em local(is) e sistema(s), previamente autorizado(s) pelo órgão de controle ambiental competente

O transporte de resíduos, além de atender a todos os requisitos da norma, deve ser realizado por transportador devidamente autorizado e licenciado. No Estado de São Paulo é necessário o CADRI - Certificado de Movimentação de Resíduos de Interesse Ambiental, que se trata de um instrumento que aprova o encaminhamento de resíduos industriais a locais de reprocessamento, armazenamento, tratamento ou disposição final, licenciados ou autorizados pela Companhia Ambiental do Estado de São Paulo (CETESB).

O CADRI consiste basicamente no preenchimento de um formulário em que constam, entre outros, a denominação, a composição, a quantidade gerada e a forma e armazenamento do excedente industrial, bem como o local para onde é enviado.

No caso de transporte terrestre de resíduos perigosos também deverão ser obedecidos os critérios de compatibilidade (conforme apresentado anteriormente no Quadro 4) e as seguintes legislações:

- Decreto n. ${ }^{\circ}$ 96.044, de 18 de maio de 1988 - Aprova o regulamento para o transporte rodoviário de produtos perigosos e dá outras providências;

- NBR 7.500/2009 - Identificação para o transporte terrestre, manuseio, movimentação e armazenamento de produtos;

- NBR 7.501/2005 - Transporte terrestre de produtos perigosos - terminologia;

- NBR 7.503/2008 - Transporte terrestre de produtos perigosos - Ficha de emergência e envelope - características, dimensões e preenchimento;

- NBR 9.734/1999 - Conjunto de equipamentos de proteção individual para avaliação de emergência e fuga no transporte rodoviário de produtos perigosos;

- NBR 9.735/2009 - Conjunto de equipamentos para emergência no transporte terrestre de produtos perigosos;

No Brasil, como em todo o mundo, a modalidade de transporte mais utilizada é a rodoviária. Os veículos mais empregados no transporte de resíduos industriais são (ROCCA, 1993; MONTEIRO, 2001): 
- Caminhões tipo poliguindaste: operam com caçambas intercambiáveis e são os mais adotados no transporte de resíduos a granel, não corrosivos e de toxidade moderada a baixa. Possui guindaste de acionamento hidráulico, para içamento e transporte de caçambas ou contêineres que acumulam resíduos sólidos. O equipamento assim constituído poderá ser do tipo simples, para transporte de uma caçamba de cada vez, ou duplo, para transporte de duas caçambas de cada vez.

- Caminhões tipo basculante: adotados para o transporte a granel de resíduos. Pode ser do tipo "toco" ou trucado. O primeiro é um veículo curto, com apenas dois eixos, dotado de caçamba de 5 a $8 \mathrm{~m}^{3}$ de capacidade. $\mathrm{O}$ caminhão basculante trucado é um veículo longo, com três eixos, dotado de caçamba de $12 \mathrm{~m}^{3}$ de capacidade.

- Caminhões-tanque: são usados para o transporte de resíduos líquidos ou pastosos bastante fluídos. No transporte de resíduos corrosivos devem-se preferir caçambas ou tanques com revestimento protetor, de material adequado, como plásticos, resinas, tintas, etc. Já para o transporte de alguns ácidos e solventes o tanque deve ser em aço inoxidável. Além disso, deve possuir dispositivos de proteção do tanque e válvulas de segurança.

- Caminhões de carroceria aberta: chamados "carga seca", indicados para transporte de todo tipo de resíduos (sólidos, líquidos e pastosos), desde que estejam bem acondicionados.

- Roll on/Roll of: caminhão coletor que opera com contêineres estacionários de 10 a $30 \mathrm{~m}^{3}$, sem compactação (dependendo do peso específico) ou de $15 \mathrm{~m}^{3}$, com compactação. Esse equipamento é dotado de dois elevadores para basculamento de contêineres plásticos de 120, 240 e 360 litros. Cada veículo pode operar com seis contêineres estacionários para obter boa produtividade.

\subsection{Tratamento e Disposição Final}

"O tratamento dos resíduos sólidos procura modificar suas características como quantidade, toxicidade e patogenia, de forma a diminuir os impactos sobre o ambiente e saúde pública" (PHILIPPI JR., 2005, p. 277). 
Tratar um resíduo significa, portanto, transformá-lo para que possa ser reutilizado ou disposto em condições mais seguras e ambientalmente aceitáveis. No caso dos resíduos industriais, tendo em vista suas características extremamente variadas existem por conseqüência diversos processos de tratamento.

Segundo Tocchetto (2007) os diversos tratamentos podem ocorrer a partir de reações químicas, físicas, biológicas e/ou térmicas. A mesma autora afirma ainda que esses tratamentos podem ser realizados em locais distintos, tais como:

- junto a própria fonte geradora;

- em outra instalação que tenha interesse em utilizar o material recuperado;

- em instalações especializadas em tratamento.

Alguns exemplos dos processos de tratamento de resíduos industriais são apresentados no Quadro 7.

Quadro 7 - Exemplos de tratamentos possíveis para resíduos industriais.

\begin{tabular}{|c|c|c|c|c|c|c|c|}
\hline \multirow[b]{2}{*}{ Resíduo } & \multirow[b]{2}{*}{ Processo de origem } & \multicolumn{6}{|c|}{$\begin{array}{l}\text { Exemplos de processos de } \\
\text { tratamento }\end{array}$} \\
\hline & & 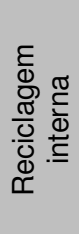 & 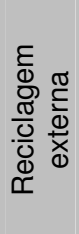 & 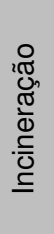 & 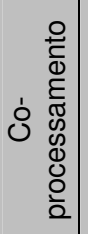 & 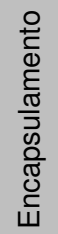 & 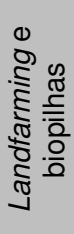 \\
\hline Plásticos & Injeção, extrusão e sopro & $x$ & $x$ & & & & \\
\hline Sucata metálica em geral & Prensagem, usinagem & & $x$ & & & & \\
\hline $\begin{array}{l}\text { Embalagens de produtos } \\
\text { químicos }\end{array}$ & $\begin{array}{l}\text { Abastecimento de matérias-primas, } \\
\text { laboratórios }\end{array}$ & & $x$ & & & & \\
\hline Resíduos de tintas & Pintura industrial & & $x$ & $x$ & $x$ & & \\
\hline Lâmpadas fluorescentes & lluminação & & $x$ & & & & \\
\hline $\begin{array}{l}\text { Resíduos de reatores } \\
\text { químicos }\end{array}$ & Produção Química & & & $x$ & $x$ & & \\
\hline Solventes clorados sujos & $\begin{array}{l}\text { Lavanderia industrial, } \\
\text { desengraxamento de peças }\end{array}$ & & $x$ & $x$ & & & \\
\hline Lodos galvânicos & & & & & & $x$ & \\
\hline $\begin{array}{l}\text { Resíduos petroquímicos } \\
\text { oleosos }\end{array}$ & & & & & & & $x$ \\
\hline
\end{tabular}

Fonte: PHILIPPI JR., 2005, p. 297.

$\mathrm{Na}$ etapa de tratamento deve-se priorizar, conforme já apresentado na hierarquia de gerenciamento dos resíduos sólidos (Capítulo 3, Figura 4), o emprego da reciclagem tanto interna, com o reaproveitamento dos materiais no mesmo 
processo que os gerou, como externa, com o reaproveitamento dos materiais num processo de outra unidade industrial.

$\mathrm{Na}$ impossibilidade de reciclar os resíduos gerados deve-se realizar a sua caracterização e classificação de acordo com as normas ABNT NBR 10.004, NBR 10.005, NBR 10.006 e NBR 10.007 para estudar a melhor alternativa para o seu tratamento e destinação final.

Muitos dos problemas de passivo ambiental enfrentados por empresas, atualmente, se devem à disposição inadequada de resíduos. Como a legislação brasileira estabelece que o responsável pela correta destinação é - gerador, as empresas não podem simplesmente contratar um terceiro para cuidar de seus resíduos, mas precisam verificar de perto, por meio de inspeções ou auditorias, os procedimentos de seus contratos.

Por outro lado, transportadores e gerenciadores de sistemas de tratamento e disposição final também são co-responsáveis, e devem estar tecnicamente capacitados para compreender as questões e riscos ambientais envolvidos em suas atividades, bem como possuir todos os recursos necessários. O contratante deve exigir, além dos documentos comerciais de praxe, todas as autorizações pertinentes dos órgãos públicos, e até mesmo certificados de treinamentos, quando for o caso (PHILIPPI JR., 2005, p.298).

Alguns métodos de tratamento e destinação final de resíduos sólidos industriais são descritos de forma sucinta a seguir.

\subsubsection{Secagem e desidratação de lodos}

Os processos de secagem e desidratação de lodos geralmente são utilizados para tratar os resíduos semi-sólidos que se originam nos processos industriais pelas operações de filtragem, decantação, destilação ou armazenagem ou ainda nas instalações de tratamento de efluentes líquidos ou gasosos.

Os resíduos são concentrados em lodos ou lamas reduzindo seu volume, o que reduz os custos para transporte até as unidades de tratamento ou destinação final.

Segundo Rocca (1993) a escolha de um método em particular vai depender das características físicas, físico-químicas e químicas do lodo e da disponibilidade de instalações para processar esses materiais.

Os métodos mais utilizados para secagem e desidratação de lodos são: centrifugação, filtragem em filtro-prensa, filtragem a vácuo e leitos de secagem. Os 
equipamentos mecânicos retêm as partículas sólidas através da passagem por uma superfície perfurada, nos quais age uma força externa contrária ao fluxo.

Os filtros prensa e as centrífugas são os equipamentos que apresentam bons resultados de desaguamento. O lodo resultante apresenta, respectivamente, 60-70\% e $70-80 \%$ de umidade. Os leitos de secagem, em condições ideais, podem igualarse aos resultados dos filtros prensa, porém são muito vulneráveis às variações climáticas, pois a perda de água ocorre por percolação e evaporação, além de requerem um tempo que pode chegar de 20 a 40 dias para atingir o percentual de umidade desejado (TOCCHETTO, 2007).

\subsubsection{Solidificação}

O processo de solidificação, também conhecido como estabilização, fixação ou encapsulamento, consiste na imobilização de resíduos perigosos transformandoos em materiais menos poluentes através da adição de compostos aglomerantes ou processos físicos, que alteram sua solubilidade e/ou mobilidade e/ou toxidez (TOCCHETTO, 2007).

Apesar da diminuição da periculosidade do resíduo, Philippi Jr. (2005) aponta que a solidificação ou encapsulamento tem o inconveniente de aumentar várias vezes o volume dos resíduos.

Comumente este tratamento é indicado para resíduos perigosos gerados em grandes quantidades, mas alguns tipos de resíduos não perigosos também podem ser tratados por esta técnica. Neste caso o tratamento é empregado quando o objetivo for facilitar o manuseio do resíduo ou dificultar a perda de constituintes indesejáveis que possam contaminar a água subterrânea quando disposto no solo.

A tecnologia de solidificação pode ser empregada para a imobilização de diversos metais pesados, certos radioisótopos e compostos orgânicos, solos contaminados, vários tipos de lodos e resíduos sólidos. Este método é adequado mais a resíduos inorgânicos do que orgânicos, devido a interferência deste último nas propriedades do produto resultante (TOCCHETTO, 2007).

Os agentes utilizados são: cimento Portland, cinzas de fornos de calcinação, óxidos, cal, calcáreo, cinzas finas, fly ash, misturas destes materiais e aglutinantes 
orgânicos como, asfalto, plásticos termocurados, borracha, termoplásticos, polímeros orgânicos dentre outros.

\subsubsection{Incineração}

A incineração é um método de tratamento térmico que emprega temperatura acima de $800^{\circ} \mathrm{C}$, conforme disposto pela Resolução CONAMA n. ${ }^{\circ} 316 / 2002$, que disciplina os processos de tratamento térmico de resíduos, estabelecendo procedimentos operacionais, limites de emissão e critérios de desempenho, controle, tratamento e disposição final.

Segundo Tocchetto (2007) a incineração objetiva:

- destruir os resíduos, inertizando-os na forma de cinzas;

- reduzir drasticamente seu volume;

- gerar energia, considerando resíduos combustíveis.

Os compostos mais adequados ao processo são os resíduos orgânicos, constituídos basicamente de carbono, hidrogênio e/ou oxigênio; resíduos que contém carbono, hidrogênio, cloro com teor inferior a 30\% em peso e/ou oxigênio e resíduos que apresentam seu poder calorífico inferior (PCI) maior que $4.700 \mathrm{kcal} / \mathrm{kg}$ (não necessitando combustível auxiliar para a queima) (ROCCA, 1993).

De maneira geral a incineração aplica-se a um grande número de resíduos orgânicos e organoclorados, não sendo adequada para tratar resíduos com metais pesados ou frações minerais muito altas.

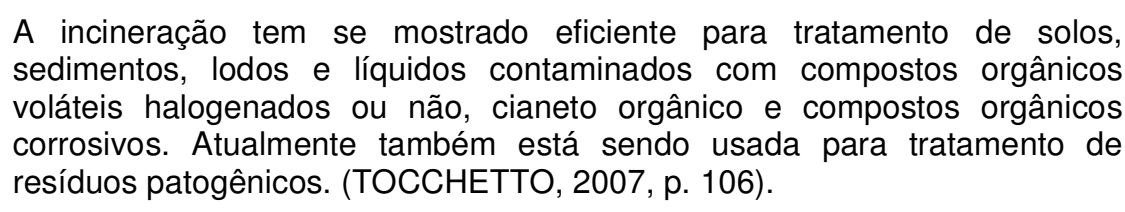

Apesar dos benefícios, a incineração traz consigo algumas preocupações: o controle dos gases emitidos pela combustão dos resíduos e a destinação das cinzas e dos particulados retidos nos sistemas de lavagem de gases.

Os incineradores devem ser dotados de equipamentos de controle de poluição para a remoção dos produtos da combustão incompleta e das emissões de particulados, de SOx e NOx. Além disso, a tecnologia de resfriamento dos gases deve minimizar a geração de dioxinas. Segundo o artigo 37 da Resolução CONAMA 
n. ${ }^{\circ} 316 / 2002$ o monitoramento e o controle dos efluentes gasosos deve incluir, no mínimo:

I - equipamentos que reduzam a emissão de poluentes, de modo a garantir o atendimento aos Limites de Emissão fixados na própria Resolução;

II - disponibilidade de acesso ao ponto de descarga, que permita a verificação periódica dos limites de emissão;

III - sistema de monitoramento contínuo com registro para teores de oxigênio $\left(\mathrm{O}_{2}\right)$ e de monóxido de carbono (CO), no mínimo, além de outros parâmetros definidos pelo órgão ambiental competente;

IV - análise bianual das emissões dos poluentes orgânicos persistentes e de funcionamento dos sistemas de intertravamento.

Deve-se também realizar a correta disposição dos resíduos sólidos resultantes (cinzas) após a incineração. Quando componentes orgânicos são incinerados, concentrações de metais aumentam nas cinzas e processos de estabilização ou inertização podem ser necessários para evitar a sua liberação para o meio ambiente. As cinzas devem ter sua composição analisada para que seja determinado o melhor método de disposição, sendo normalmente utilizados os aterros industriais (MAROUN, 2006).

\subsubsection{Co-processamento}

No co-processamento os resíduos são aproveitados como combustíveis, em geral em fornos de clínquer (fábricas de cimento) ou fornos de cal, resultando na destruição térmica eficiente e segura, sob o ponto de vista operacional e ambiental.

A Resolução CONAMA n. ${ }^{\circ}$ 264/1999 estabelece os seguintes critérios básicos para utilização de resíduos para fins de co-processamento:

- O resíduo pode ser utilizado como substituto da matéria-prima desde que apresente características similares às dos componentes normalmente empregados na produção de clínquer, incluindo neste caso os materiais mineralizadores e/ou fundentes. 
- O resíduo pode ser utilizado como substituto de combustível, para fins de reaproveitamento de energia, desde que o ganho de energia seja comprovado.

Segundo Philippi Jr. (2005, p. 296) este processo é "adequado para resíduos com poder calorífico e isentos de cloro e flúor (que poderiam atacar as paredes dos fornos), com teores de metais pesados não muito altos, e que tenham fração mineral que possa ser absorvida pela cal ou pelo cimento".

A produção de cimento exige que a temperatura do material ultrapasse $1.400^{\circ} \mathrm{C}$, enquanto a temperatura dos gases do forno chega até $2.000^{\circ} \mathrm{C}$, necessitando para isso, de combustíveis com alto valor energético, portanto diversos resíduos que possuem estas características podem ser usados, como restos de solventes, tintas endurecidas, tinner e pneus velhos.

O processo de queima em fornos de cimento é capaz de reduzir a utilização dos combustíveis, como carvão ou óleo combustível, necessários para alimentação do forno. As cinzas, por sua vez, são totalmente incorporadas ao clínquer, não havendo a necessidade de disposição em aterros. Perfeitas condições de coprocessamento podem também ser conseguidas em fornos siderúrgicos, caldeiras de variados tipos ou fornos industriais, desde que compatibilizados ao tipo de resíduo a ser queimado (TOCCHETTO, 2007).

\subsubsection{Landfarming}

No sistema de tratamento por landfarming os resíduos são aplicados na superfície ou no interior do horizonte superficial do solo de maneira controlada e acompanhada por práticas de manejo e monitoramento constantes. Durante este processo os resíduos são biodegradados, destoxificados, transformados e imobilizados pela atividade microbiana aeróbia do solo reduzindo assim, os riscos de contaminação ambiental.

O emprego do landfarming é adequado para a remediação biológica de solos contaminados, lodos ou material com características, cuja ação dos microorganismos gera substâncias inócuas para o ambiente ou subprodutos estabilizados que não representam perigo. Os seguintes resíduos também podem 
ser tratados por este processo: derivados de petróleo, como óleo diesel e óleos combustíveis tipo 2 e 4; alguns pesticidas; borras oleosas; conservante de madeira; creosoto e resíduos de coque (TOCCHETTO, 2007).

Segundo Rocca (1993) o que torna este sistema atraente são os baixos custos de implantação e operação envolvidos, além da possibilidade de tratamento e disposição final simultânea de uma ampla variedade de resíduos, inclusive líquidos e os resíduos perigosos (Classe I). O quadro a seguir apresenta as vantagens e desvantagens deste sistema.

Quadro 8 - Vantagens e desvantagens do processo de tratamento de resíduos por landfarming.

\begin{tabular}{|c|c|}
\hline VANTAGENS & DESVANTAGENS \\
\hline $\begin{array}{l}\text { - Projeto e implantação relativamente } \\
\text { simples; } \\
\text { - Tempo pequeno de tratamento } \\
\text { (usualmente de } 6 \text { a } 2 \text { anos em condições } \\
\text { ótimas); } \\
\text { - Custo competitivo: } \$ 30-60 / \text { tonelada de } \\
\text { solo contaminado; } \\
\text { - Eficiente para constituintes orgânicos } \\
\text { com baixa biodegradabilidade. }\end{array}$ & $\begin{array}{l}\text { - Redução de concentração maiores que 95\% e } \\
\text { concentrações menores que } 0,1 \text { ppm são muito difíceis } \\
\text { de serem alcançadas; } \\
\text { - Pouco eficiente para constituintes pesados (maior que } \\
50 \text { ppm); } \\
\text { - Presença de metais pesados pode inibir o crescimento } \\
\text { microbiano (acima de } 2,5 \text { ppm); } \\
\text { - Presença de compostos voláteis que tendem a } \\
\text { evaporar antes do processo de biodegradação; } \\
\text { - Requer grandes extensões de terra para o tratamento; } \\
\text { - Geração de poeiras e vapores durante a aeração da } \\
\text { célula; } \\
\text { - Requer rede para coleta de lixiviados e tratamento. }\end{array}$ \\
\hline
\end{tabular}

Fonte: Tocchetto, 2007, p. 126.

\subsubsection{Aterro Industrial}

O aterro é uma forma de disposição de resíduos no solo fundamentada em critérios de engenharia e normas operacionais específicas de forma a garantir um confinamento seguro em termos de poluição ambiental e proteção a saúde pública.

Os aterros podem ser denominados aterros sanitários, quando projetados e implantados especialmente para a disposição de resíduos sólidos urbanos, ou aterros industriais, quando projetados e implantados especialmente para disposição de resíduos sólidos industriais (ROCCA, 1993, p. 167).

Os aterros industriais requerem projeto e execução mais elaborados que os aterros sanitários, em razão do tipo de materiais que deverão receber, especialmente, quando se trata de resíduos perigosos. O monitoramento tem que ser permanente, a fim de prevenir a possibilidade de contaminação do solo e das 
águas subterrâneas. Deve-se também procurar reduzir ao mínimo a quantidade de material lixiviado emitido pelo aterro industrial, evitando-se a disposição de resíduos muito úmidos e pastosos. Não obstante, os líquidos lixiviados devem ser constantemente analisados e tratados antes de lançados no corpo receptor (TOCCHETTO, 2007).

Segundo Maroun (2006) dentre as vantagens dos aterros industriais tem-se seu baixo custo em relação a outras opções de tratamento e disposição, como a incineração; e a possibilidade de ser utilizado para uma grande variedade de resíduos. Já dentre as desvantagens menciona-se a necessidade de uma grande área física para construção e operação e a geração de um passivo que precisa ser continuamente monitorado. 


\section{IMPLANTAÇÃO DE UM PROGRAMA DE PRODUÇÃO MAIS LIMPA}

A implantação de um programa de produção mais limpa numa atividade requer o cumprimento de uma série de etapas. Essas vão desde o comprometimento da alta administração e envolvimento dos funcionários, seguido de um exaustivo trabalho de levantamento de dados e informações para a avaliação do processo e identificação de oportunidades, busca e análise de viabilidade das alternativas para os problemas identificados, implantação das alternativas e posterior monitoramento do desempenho, para que o programa possa então ser avaliado, revisado e corrigido, garantindo a melhoria contínua do processo.

Para auxiliar o desenvolvimento dessas etapas existem guias e manuais gerais e específicos disponíveis na Internet que permitem a implantação de um programa de produção mais limpa em qualquer tipo de atividade. O programa pode ainda ser desenvolvido em qualquer empresa seja ela de pequeno, médio ou grande porte.

As metodologias propostas por estes guias não diferem de maneira geral entre si. O importante é que as organizações procurem a melhor forma de implantar seu programa. Nas figuras a seguir são apresentadas as etapas de implantação do programa de produção mais limpa de diferentes instituições.

O guia disponibilizado pelo Centro Empresarial Brasileiro para 0 Desenvolvimento Sustentável (CEBDS) para implementação da metodologia de produção mais limpa (Figura 8) segue a abordagem da UNIDO/UNEP sendo detalhado em 18 etapas. 


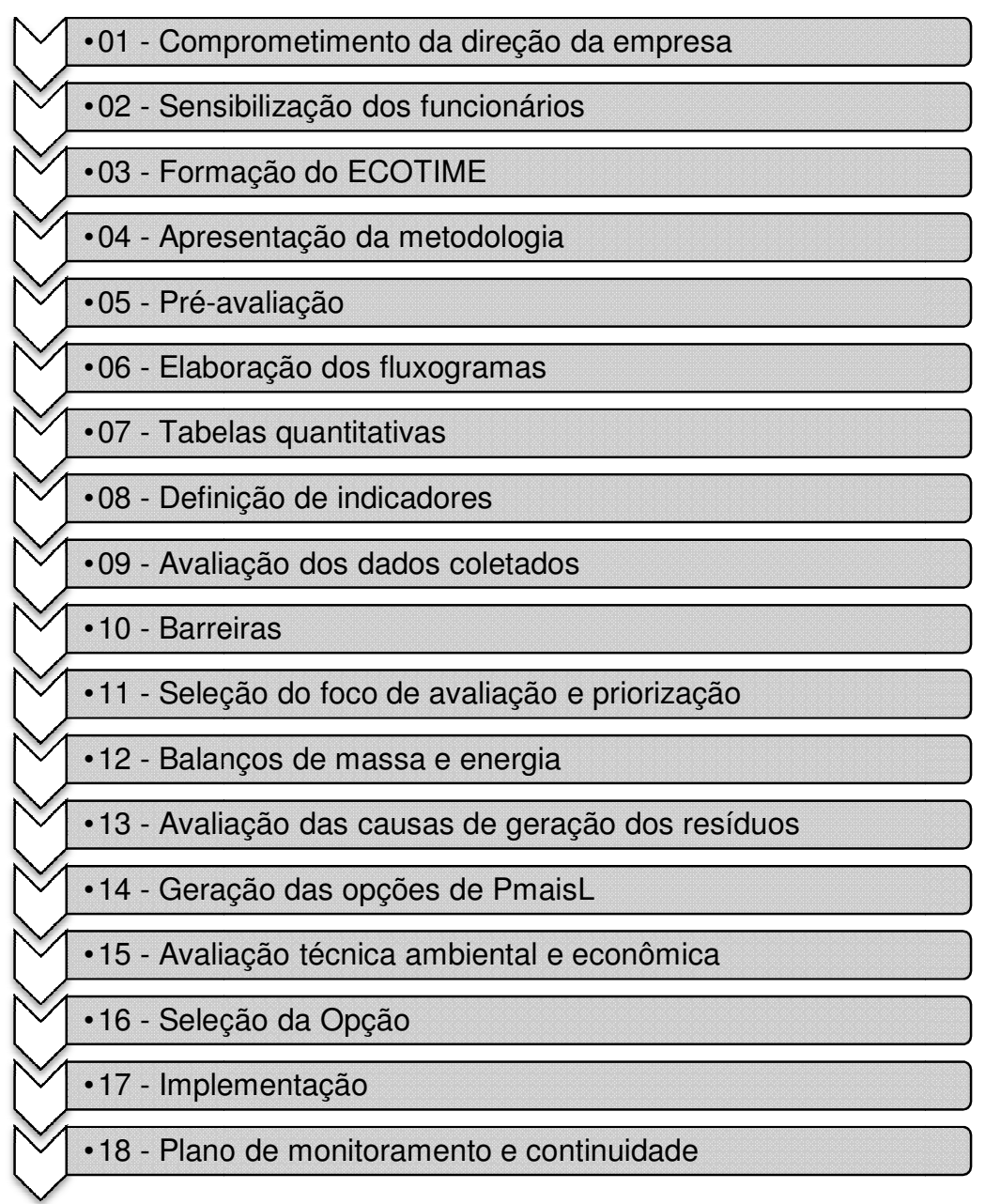

Figura 8 - Etapas da metodologia do CEBDS para implantação da produção mais limpa.

Fonte: CEBDS, 2003, p. 11

O guia do Centro Nacional de Tecnologias Limpas (CNTL) sugere a sistemática mostrada na Figura 9 em seus materiais de divulgação. A metodologia conta com 5 etapas: planejamento e organização, pré-avaliação, avaliação, estudo de viabilidade, e implementação; etapas essas que devem ser realizadas de forma contínua pela empresa. 


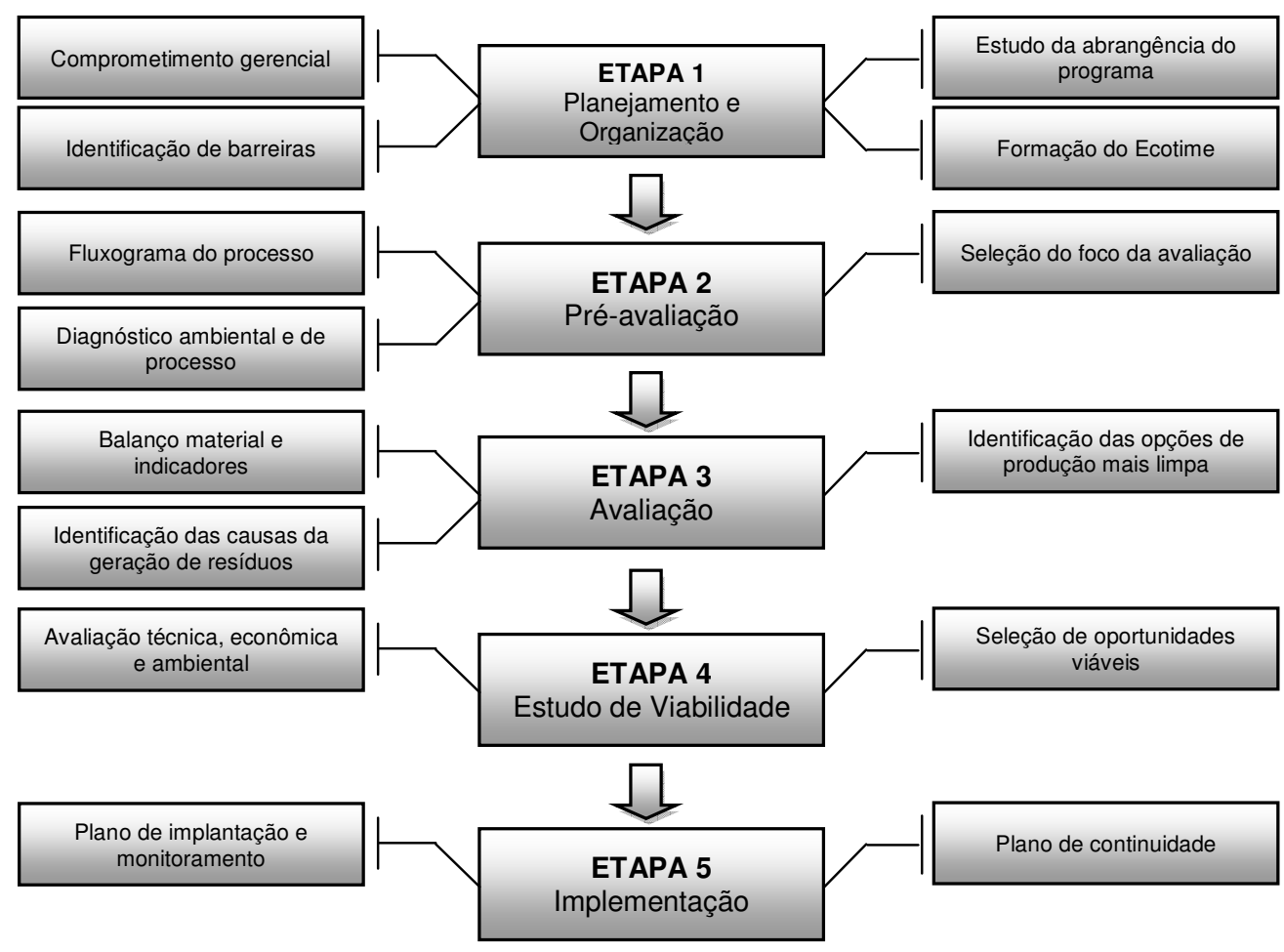

Figura 9 - Sistemática para a implementação de um programa de Produção mais Limpa.

Fonte: Adaptado de CNTL, 2003a, p. 19.

No site da Companhia Ambiental do Estado de São Paulo (CETESB) existem guias elaborados para setores produtivos específicos que contem a descrição dos processos, seus principais impactos ambientais potenciais e medidas de produção mais limpa aplicáveis a cada um. Os setores contemplados até o momento são:

- Papel e celulose;

- Tintas e vernizes;

- Abate de suínos e bovinos;

- Cerâmica branca e de revestimento;

- Frigoríficos - industrialização de carne bovina e suína;

- Graxarias - processamento de materiais de abatedouros e frigoríficos de bovinos e suínos;

- Produtos lácteos;

- Cervejarias e refrigerantes;

- Curtumes;

- Bijuterias; 
- Sucos cítricos;

- Indústria gráfica;

- Indústria de higiene pessoal, perfumaria e cosméticos, e

- Indústria têxtil.

Além deste material específico por setor a CETESB apresenta o manual de implementação de um programa de prevenção à poluição que segue as etapas apresentadas na Figura 10.

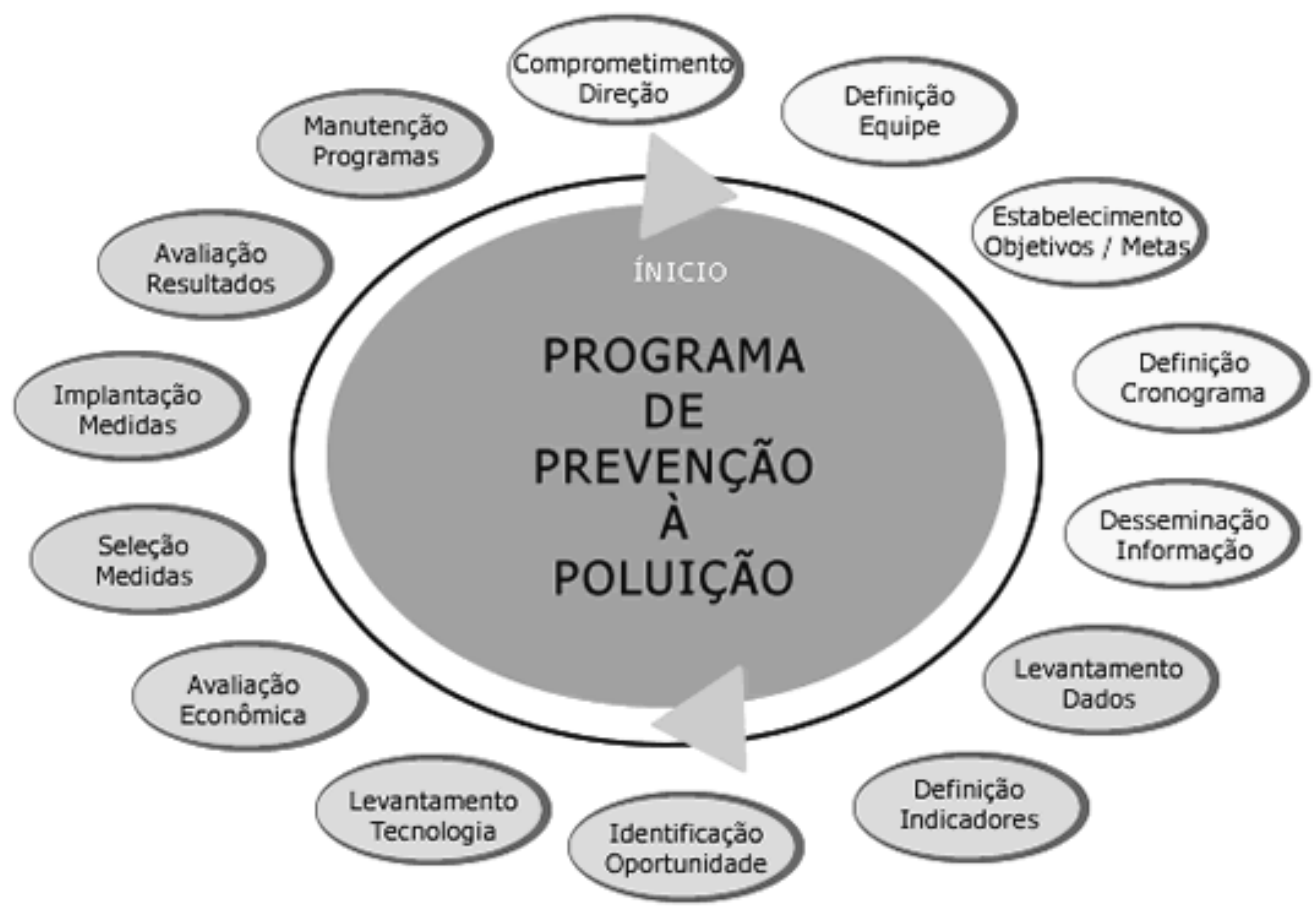

Figura 10 - Etapas recomendadas pela CETESB para um programa de prevenção à poluição.

Fonte: CETESB, 2010

A seguir, com base nas metodologias apresentadas são detalhadas as etapas de implantação de um programa de produção mais limpa.

\subsection{Comprometimento gerencial}

Em todas as metodologias nota-se que para iniciar o programa é indispensável o comprometimento da direção da empresa e conseqüente sensibilização dos funcionários. O levantamento dos dados, a escolha de 
alternativas e a posterior implantação do plano dependem de um trabalho conjunto de toda a empresa.

A direção da empresa poderá apresentar formalmente sua aceitação e comprometimento através de uma Declaração de Intenções (Figura 11), onde os objetivos e as prioridades gerais do programa devem estar inseridos. Esta declaração deverá ser divulgada a todos os interessados, ou seja, funcionários, fornecedores e clientes (CETESB, 2002).

\section{DECLARAÇÃO DE INTENÇÕES}

$\mathrm{Na}$ [..nome da empresa...], a proteção do meio ambiente está sendo priorizada através da implantação do Programa de Prevenção à Poluição.

Esta empresa se compromete a reduzir ou eliminar o uso de substâncias tóxicas, a emissão de poluentes e a geração de todos os tipos de resíduos, principalmente os perigosos.

Nós nos comprometemos em minimizar qualquer impacto indesejável no ar, água e solo, mesmo quando o uso de substâncias tóxicas, a geração de resíduos sólidos ou a emissão de poluentes tóxicos não puderem ser evitados.

Direção da Empresa

Figura 11 - Exemplo de Declaração de Intenções.

Fonte: CETESB, 2002, p. 5.

\subsection{Formação do Ecotime}

O ecotime, conforme proposto pelo CEBDS (2003) e CNTL (2003a), deve ser composto por funcionários de vários setores que conheçam a empresa mais profundamente e/ou responsáveis por áreas importantes, como produção, compras, meio ambiente, qualidade, saúde e segurança, desenvolvimento de produtos, manutenção e vendas.

O número de pessoas que deverá integrar o ecotime vai depender do tamanho e estrutura da empresa. Naquelas de pequeno porte onde uma mesma 
pessoa pode ser responsável por várias funções (setores) devem ser escolhidos dois ou três funcionários "chave".

O CNTL (2003c) sugere que mesmo com a formação do ecotime a condução da avaliação de produção mais limpa seja realizada por uma pessoa estranha a empresa. Essa pode então contar com um consultor externo que tenha conhecimento mais aprofundado do programa de forma a complementar e suprir o ecotime com eventuais deficiências técnicas.

O ecotime será responsável pelo desenvolvimento, acompanhamento, implantação das medidas de produção mais limpa, avaliação e manutenção do programa, de acordo com as necessidades e potencialidades da empresa. Para o bom desenvolvimento destas ações podem ser definidas responsabilidades individuais para cada membro do ecotime, conforme proposto pelo manual da CETESB (2002) e apresentado no quadro a seguir.

Quadro 9 - Exemplo de formação do ecotime e distribuição das responsabilidades.

\begin{tabular}{|l|c|l|}
\hline Membro da Equipe & Posição na Fábrica & \multicolumn{1}{c|}{ Responsabilidade } \\
\hline Nome & Gerente Geral & $\begin{array}{l}\text { - Supervisão do programa } \\
\text { - Representação da empresa } \\
\text { - Decisão final }\end{array}$ \\
\hline Nomes & Líder e Encarregados & $\begin{array}{l}\text { - Operação diária } \\
\text { - Comunicação com os funcionários } \\
\text { - Controle de custos }\end{array}$ \\
\hline Nomes & Químico e Analista de Laboratório & $\begin{array}{l}\text { - Realização de testes, documentação e } \\
\text { monitoramento } \\
\text { - Coleta de amostras e análises }\end{array}$ \\
\hline Nomes & Operários & $\begin{array}{l}\text { - Coleta de informaçães e inclusão no } \\
\text { programa quando necessário }\end{array}$ \\
\hline Nomes & Consultores & $\begin{array}{l}\text { - Auxílio no planejamento da proposta } \\
\text { de produção mais limpa }\end{array}$ \\
\hline Nomes & Fornecedores & - Prestação de informações técnicas \\
\hline
\end{tabular}

Fonte: Adaptado de CETESB, 2002, p. 6.

Nesta etapa inicial de planejamento e organização a empresa já pode definir a abrangência do programa de produção mais limpa, por exemplo, pode-se direcionar o foco do estudo para um setor crítico ou incluir todos os setores da empresa.

O ecotime deve iniciar o levantamento dos dados através de uma inspeção visual nas instalações, visando identificar os possíveis impactos ambientais da atividade e como os resíduos são manuseados. O atendimento da legislação como um todo e em especial à ambiental também deve ser verificado. 
O CEBDS (2003) sugere que seja feito o "lay out" das instalações, mostrando a disposição dos equipamentos, bancadas e materiais, indicando, através de setas, os caminhos de movimentação interna dos produtos intermediários que são fabricados em cada etapa e dos resíduos.

Segundo Oliveira (2006, p. 43) "a análise do 'lay-out' das instalações permite reposicionar equipamentos e tarefas, de modo a otimizar deslocamento, reduzir esforços e, assim economizar recursos e principalmente energia."

\subsection{Barreiras}

A implantação de um programa de produção mais limpa gera ganhos econômicos e reduções significativas nos impactos ambientais de uma atividade. Apesar dos seus benefícios uma série de barreiras potenciais podem impedir ou retardar a adoção da produção mais limpa nas empresas. O CNTL (2003c) classifica estas barreiras conforme apresentado no quadro a seguir.

Quadro 10 - Barreiras a implementação do programa de produção mais limpa.

\begin{tabular}{|c|c|}
\hline Barreiras & Descrição \\
\hline Organizacionais & $\begin{array}{l}\text { - Não envolvimento dos funcionários nas atividades de gestão ambiental; } \\
\text { - Concentração das tomadas de decisão nas mãos da alta direção; } \\
\text { - Ênfase excessiva na quantidade de produção em detrimento da minimização } \\
\text { dos problemas ambientais; } \\
\text { - Alta rotatividade de pessoal técnico limitando a capacidade da empresa para } \\
\text { trabalhar com as medidas de minimização; } \\
\text { - Falta de reconhecimento desmotiva os funcionários a iniciar novas atividades. }\end{array}$ \\
\hline Sistêmicas & $\begin{array}{l}\text { - Falhas na documentação dificultam o processo de levantamento de dados; } \\
\text { - Sistema de gerenciamento inadequado ou ineficiente - leva os funcionários a } \\
\text { evitar qualquer atividade fora da rotina; } \\
\text { - Falta de sistemas para promoção profissional - a falta de treinamento torna os } \\
\text { funcionários incapazes de compreender novos assuntos; } \\
\text { - Planejamento de produção "Ad Hoc" - o plano de produção preparado numa } \\
\text { base diária atrapalha qualquer trabalho sistemático, quer seja de coleta de } \\
\text { dados ou avaliação de impacto das medidas implantadas. }\end{array}$ \\
\hline Técnicas & $\begin{array}{l}\text { - Falta de infra-estrutura para conduzir os estudos, limitando a coleta de dados; } \\
\text { - Mão de obra limitada ou não disponível para atuar/guiar programas de } \\
\text { minimização de resíduos na empresa ou no local; } \\
\text { - Acesso limitado à informação técnica e de estudos de casos de minimização } \\
\text { de resíduos no país e no exterior. Informações disponíveis no exterior podem } \\
\text { não ser relevantes ou adequadas para pequenas indústrias; } \\
\text { - Tecnologia limitada; } \\
\text { - Infra-estrutura limitada na manutenção própria, geralmente nas pequenas } \\
\text { indústrias. }\end{array}$ \\
\hline
\end{tabular}

Continua 
Conclusão

\begin{tabular}{|l|l|}
\hline Barreiras & Descrição \\
\hline \multirow{5}{*}{ Econômicas } & - Preços baixos e a disponibilidade de recursos naturais reprimem o impulso de \\
implantar medidas de minimização de resíduos; \\
- Indisponibilidade de fundos e custos elevados desses para implantação de \\
medidas de minimização de resíduos, pelo baixo interesse das instituições \\
financeiras; \\
- Exclusão dos custos ambientais da análise econômica; \\
- Planejamento inadequado de investimentos para as medidas de minimização; \\
- Critérios para investimento "Ad hoc" pela restrição de capital; \\
- Predominância de incentivos fiscais relativos à produção.
\end{tabular}

Fonte: Elaborado a partir de CNTL, 2003c, p. 20-25.

Durante a implantação do programa as barreiras encontradas pela equipe devem ser contornadas. Segundo o CNTL (2003c) o primeiro passo para superação das barreiras é a conscientização sobre os benefícios da produção mais limpa e de que o processo não busca culpados. Deve-se manter um ambiente para que todos sintam-se livres e confortáveis para dar sugestões e idéias.

\subsection{Fluxograma do processo}

A próxima etapa é a elaboração do fluxograma qualitativo ou diagrama de fluxo do processo, onde se identifica a seqüência de etapas que compõem o processo produtivo (unidades de processo), cada qual com suas entradas e saídas de material, energia e trabalho (Figura 12). 


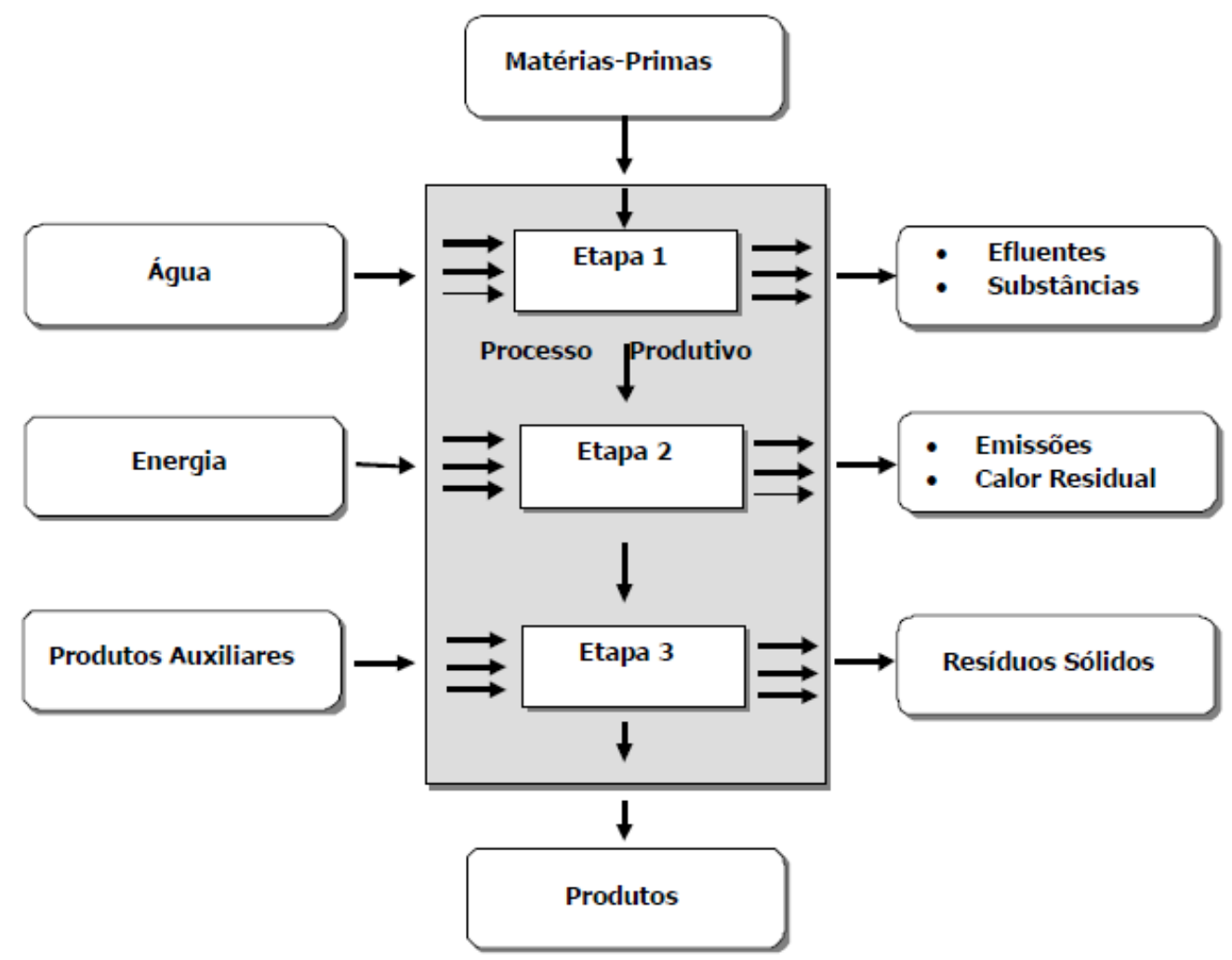

Figura 12 - Fluxograma qualitativo do processo produtivo.

Fonte: CNTL, 2003a, p. 21.

A separação do processo global em unidades de processo permite isolar e quantificar impactos ambientais que passariam desapercebidos ao se analisar o processo de forma global (EC ${ }^{19}, 2001$ apud SANTOS, 2005).

O diagrama de fluxo serve, portanto, como uma ferramenta de visualização das etapas do processo produtivo auxiliando no seu entendimento e, conseqüentemente, na sua análise para a viabilização da produção mais limpa.

Conforme o CNTL (2003a, p. 20),

A análise detalhada do fluxograma permite a visualização e a definição do fluxo qualitativo de matéria-prima, água e energia no processo produtivo, visualização da geração de resíduos durante o processo, agindo desta forma como uma ferramenta para obtenção de dados necessários para a formação de uma estratégia de minimização da geração de resíduos, efluentes e emissões.

Com base nos fluxogramas qualitativos segue-se então ao levantamento dos dados quantitativos (Figura 13).

19 ENVIRONMENT CANADA - EC. Pollution Prevention Planning Handbook. Canadian Environment Protection Agency, Canada. 2001. 


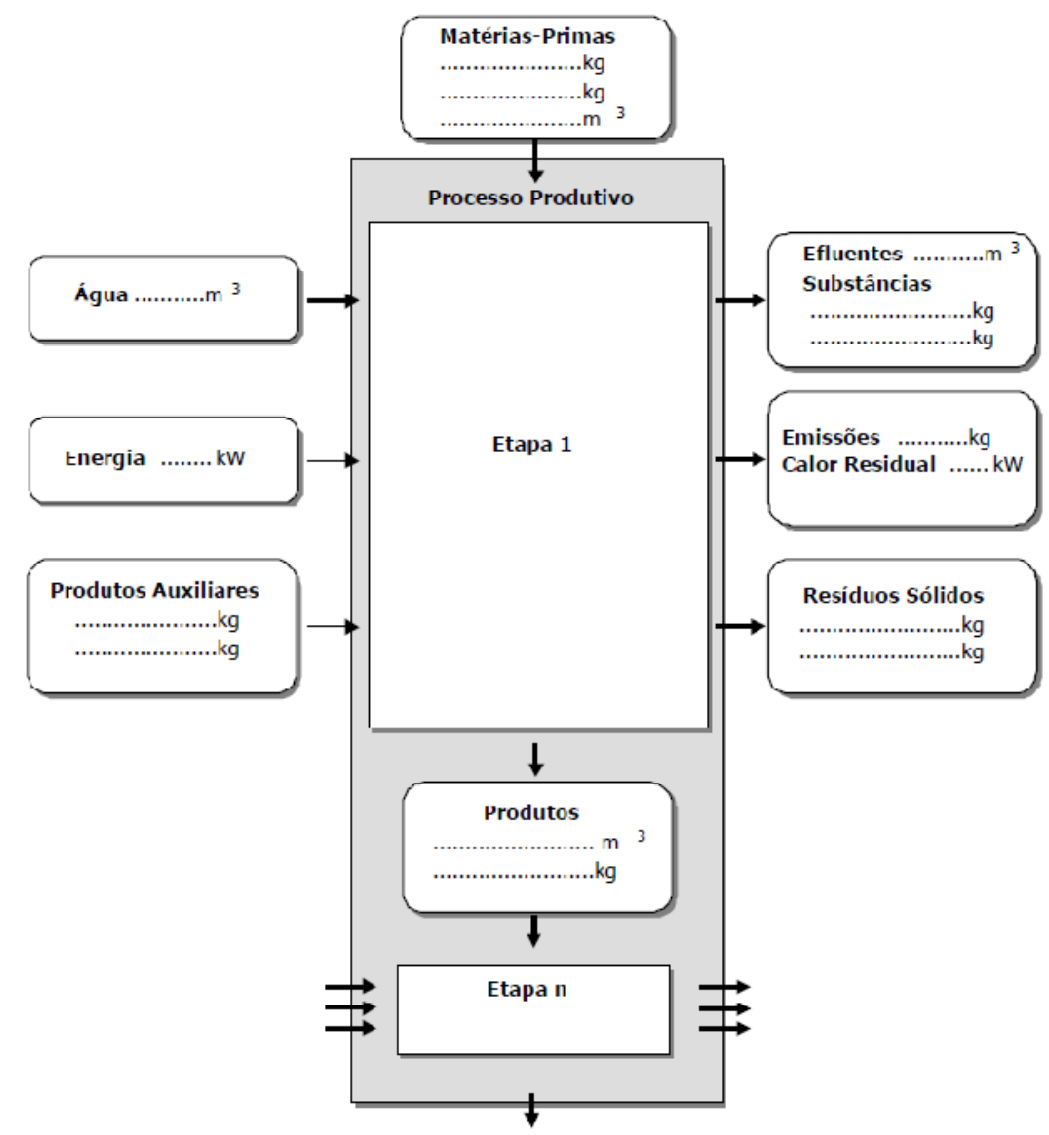

Figura 13 - Análise quantitativa de entradas e saídas do processo produtivo. Fonte: CNTL, 2003a, p. 24.

Segundo a Environment Canada ${ }^{20}$ (2001 apud SANTOS, 2005) os dados de entrada podem ser obtidos em relatórios da planta ou unidade, que normalmente armazenam registros de compra de materiais, inventários de estoque, relatórios de prestação de contas, etc. Outras entradas, como água e energia podem ser medidas diretamente com equipamentos adequados.

$\mathrm{Na}$ quantificação das saídas do sistema, no caso do produto final, os dados podem ser obtidos em relatórios de venda ou outros relatórios de controle interno. Já na quantificação dos subprodutos e perdas o levantamento torna-se mais difícil, uma vez que de maneira geral as companhias não costumam medir suas perdas rotineiramente e de maneira sistemática. As perdas englobam as emissões atmosféricas, efluentes líquidos, resíduos diversos que são encaminhados para disposição ou reciclagem fora da planta, e resíduos armazenados na planta (SANTOS, 2005).

${ }^{20}$ Ibid. 
As notas de transferência (transporte, tratamento e disposição final) de resíduos sólidos ou líquidos podem ser utilizadas como fonte de coleta de dados para as saídas de subprodutos e perdas, além das medições e amostragens diretas, monitoramento, cálculos e estimativas.

O CEBDS (2003) aconselha considerar 1 (um) ano como base de cálculo dos valores quantitativos de resíduos gerados, de matérias-primas, água e energia consumidas e de produtos fabricados.

\subsection{Seleção do foco de priorização}

Considerando que a avaliação de uma instalação ou processo produtivo sob os critérios da produção mais limpa envolve em conjunto os aspectos técnicos, ambientais e econômicos e que os resultados esperados são: a melhoria na saúde ocupacional e no meio ambiente, com redução de custos para a organização; faz-se necessário a priorização dos processos a serem avaliados, a fim de se chegar a um melhor benefício global para os envolvidos e partes interessadas.

Para o CNTL (2003a), de posse das informações do diagnóstico ambiental e da planilha com os principais aspectos ambientais seleciona-se, entre todas as atividades e operações da empresa, o foco do trabalho. As informações devem ser analisadas considerando os regulamentos legais, a quantidade de resíduos gerados, a toxidade dos resíduos e os custos envolvidos.

O CEBDS (2003) propõe que os dados coletados nas etapas anteriores e a disponibilidade de recursos financeiros sejam utilizados para definir as etapas, processos, produtos ou equipamentos que serão priorizados para as efetivas medições e realização dos balanços de massa e energia.

De maneira geral, cabe a equipe responsável pelo programa, ou seja, 0 ecotime, analisar qual atividade deve ser priorizada para a identificação de oportunidades de produção mais limpa. Pode-se focar, inicialmente, nas atividades que estejam apresentando maiores problemas, por exemplo, caso a empresa já tenha sofrido penalidades legais em virtude do gerenciamento dos resíduos gerados em qualquer fase do seu processo industrial, pode estudar alternativas para reduzir a quantidade e/ou toxidade dos mesmos. 
Deve-se notar que por tratar-se de um programa contínuo, diferentes focos podem ser adotados consecutivamente ao longo da aplicação da produção mais limpa na empresa.

\subsection{Definição dos indicadores}

"Os indicadores são ferramentas técnico-gerenciais importantes para orientar a tomada de decisão e estabelecer parâmetros comparativos de processos" (OLIVEIRA, 2006, p. 48). Através dos indicadores é possível acompanhar a evolução da empresa antes e após a implantação das medidas de produção mais limpa, bem como uma análise dos ganhos obtidos em termos ambientais e econômicos, além da possibilidade de comparações futuras com outras atividades semelhantes ou entre empresas.

Para o CNTL (2003d) o uso dos indicadores ambientais têm os seguintes objetivos:

- Ilustrar melhorias ambientais ao longo do tempo em determinadas avaliações;

- Detectar potenciais para melhorias no processo produtivo;

- Definir objetivos e metas de performance ambiental;

- Monitorar a performance ambiental;

- Identificar oportunidades para produção mais limpa;

- Facilitar a realização de Benchmarking Ambiental;

- Fornecer dados para publicações referentes a Relatórios Ambientais;

- Promover a motivação do público interno;

- Proporcionar uma base para implantação de Sistemas de Gestão Ambiental. Na NBR 14.031 descrevem-se duas categorias gerais de indicadores a serem considerados na condução de uma avaliação de desempenho ambiental (ALBIERO FILHO, 2010):

- Indicadores de Condição Ambiental (ICA): fornecem informações sobre a qualidade do meio ambiente onde se localiza a indústria, sob a forma de resultados de medições efetuadas de acordo com os padrões e regras ambientais estabelecidos pelas normas e dispositivos legais.

- Indicadores de Desempenho Ambiental (IDA): são classificados em dois tipos: 
(4) Indicadores de Desempenho de Gestão (IDG) - fornecem informações relativas a todos os esforços de gestão da empresa que influenciam positivamente no seu desempenho ambiental, por exemplo, reduzindo o consumo de materiais e/ou melhorando a administração de seus resíduos sólidos, mantendo os mesmos valores de produção.

4) Indicadores de Desempenho Operacional (IDO) - proporcionam informações relacionadas às operações do processo produtivo da empresa com reflexos no seu desempenho ambiental, tais como o consumo de água, energia ou matéria-prima.

Nota-se que os ICA apresentam informações quanto as interações da empresa com seu ambiente externo, já os IDA fornecem dados internos quanto a gestão e a operação.

O detalhamento desses indicadores deverá fundamentar-se nos objetivos e metas do programa de produção mais limpa e no foco de atuação selecionado. Os primeiros indicadores podem ser construídos através dos dados levantados, nos fluxogramas quali e quantitativos e em informações disponíveis na empresa, sendo que 0 espectro de indicadores pode ser ampliado na medida em que se julgue necessário considerar outras variáveis, inicialmente não contempladas.

Deve-se notar que o estabelecimento de indicadores trata-se de um trabalho quase sempre árduo, sendo que os primeiros indicadores definidos deverão auxiliar na elaboração do plano de monitoramento e na definição dos dados necessários à construção de novos indicadores (CNTL, 2003d).

Alguns exemplos de indicadores operacionais e gerenciais são apresentados no Quadro 11. 
Quadro 11 - Exemplo de indicadores de desempenho operacional e gerencial.

\begin{tabular}{|c|c|c|}
\hline \multicolumn{2}{|c|}{ FOCO DA AVALIAÇÃO } & EXEMPLO DE INDICADORES \\
\hline \multirow{8}{*}{ 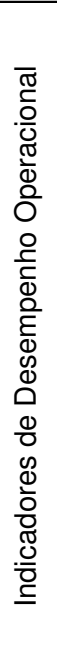 } & Matéria-prima & $\begin{array}{l}\text { - quantidade de materiais usados/produto } \\
\text { - materiais ou matéria-prima reciclados ou reutilizados } \\
\text { - embalagens descartadas ou reutilizadas/produto }\end{array}$ \\
\hline & Energia & $\begin{array}{l}\text { - tipo de energia usada/ano ou por produto ou serviço } \\
\text { - tipo de energia gerada com subprodutos ou correntes de processo }\end{array}$ \\
\hline & Água & $\begin{array}{l}\text { - água consumida/ano ou por produto } \\
\text { - água reutilizada/ano ou por produto }\end{array}$ \\
\hline & $\begin{array}{l}\text { Fornecimento e } \\
\text { distribuição }\end{array}$ & - consumo médio de combustível da frota de veículos \\
\hline & Resíduos & $\begin{array}{l}\text { - resíduos gerados/ano ou por produto } \\
\text { - resíduos perigosos, recicláveis ou reutilizáveis produzidos/ano } \\
\text { - resíduos perigosos eliminados devido a substituição de material }\end{array}$ \\
\hline & Efluentes líquidos & - volume de efluente /produto \\
\hline & Emissões & $\begin{array}{l}\text { - emissões atmosféricas prejudiciais à camada de ozônio } \\
\text { - emissões de gases de efeito estufa, em } \mathrm{CO}_{2} \text { equivalentes/ano ou por } \\
\text { produto }\end{array}$ \\
\hline & Ruído & - nível de ruído \\
\hline \multirow{4}{*}{ 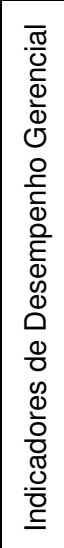 } & $\begin{array}{l}\text { Implementação de } \\
\text { políticas e } \\
\text { programas }\end{array}$ & $\begin{array}{l}\text { - número de iniciativas implementadas para a prevenção de poluição } \\
\text { - níveis gerenciais com responsabilidades ambientais específicas } \\
\text { - número de empregados que participam em treinamentos ambientais }\end{array}$ \\
\hline & Conformidade & $\begin{array}{l}\text { - número de multas e penalidades ou reclamações e os custos a elas } \\
\text { atribuidos }\end{array}$ \\
\hline & $\begin{array}{l}\text { Desempenho } \\
\text { financeiro }\end{array}$ & $\begin{array}{l}\text { - gastos (operacional e de capital) associados com a gestão e controle } \\
\text { ambiental } \\
\text { - economia obtida através da gestão e controle ambiental } \\
\text { - responsabilidade legal ambiental que pode ter um impacto material na } \\
\text { situação financeira da indústria }\end{array}$ \\
\hline & $\begin{array}{l}\text { Relações com a } \\
\text { comunidade }\end{array}$ & $\begin{array}{l}\text { - número de programas educacionais ambientais ou quantidade de } \\
\text { materiais fornecidos à comunidade } \\
\text { - índice de aprovação em pesquisas nas comunidades }\end{array}$ \\
\hline
\end{tabular}

Fonte: Adaptado de Albiero Filho, 2010, p. 19-20.

Tendo em vista o enfoque desta pesquisa no gerenciamento de resíduos sólidos apresenta-se no Quadro 12 indicadores propostos pelo CNTL (2003d) associados à geração de resíduos.

Quadro 12 - Lista de indicadores associados à geração de resíduos.

\begin{tabular}{|l|c|c|}
\hline INDICADOR & DESCRIÇAO & UNIDADE \\
\hline Total de resíduos gerados & Valor absoluto & $\mathrm{Kg}$ \\
\hline Geração específica sobre o total & Tipo de resíduo/Total de produto & $\mathrm{Kg} / \mathrm{Kg}$ \\
\hline Resíduo para reciclagem & Valor absoluto & $\mathrm{Kg}$ \\
\hline Resíduo para disposição & Valor absoluto & $\mathrm{Kg}$ \\
\hline Porcentual reciclado & Resíduo reciclado/Total gerado de resíduos & $\%$ \\
\hline Resíduo Classe I, IIA, IIB & $\begin{array}{c}\text { Montante de resíduos por classe/Total } \\
\text { gerado de resíduos }\end{array}$ & $\%$ \\
\hline Custos dos resíduos & Valor absoluto & $\mathrm{R} \$$ \\
\hline Custos específicos dos resíduos & Total de Custos/Custo total de produção & $\%$ \\
\hline
\end{tabular}

Fonte: Adaptado de CNTL, 2003d, p. 19. 
No caso dos resíduos sólidos, outros indicadores, além dos propostos no quadro anterior, podem ser propostos pelas empresas para fazer parte do programa de produção mais limpa ou do Plano de Gerenciamento de Resíduos Sólidos, como forma de acompanhar seu desempenho ambiental.

\subsection{Balanço material}

De posse das quantidades de entrada e saída das unidades de processo (fluxograma quantitativo) se realiza o balanço material. Segundo Himmelblau ${ }^{21}$ (1984 apud SANTOS, 2005, p. 141) "um balanço material é uma contabilidade de fluxos de materiais dentro de um sistema com base na lei da conservação de massa, aplicável a processos com ou sem reação química, expressado pela seguinte equação de balanço:"

$$
\left\{\begin{array}{c}
\text { Acúmulo } \\
\text { de massa } \\
\text { dentro do } \\
\text { sistema }
\end{array}\right\}=\left\{\begin{array}{c}
\text { Entrada de } \\
\text { massa nos } \\
\text { limites do } \\
\text { sistema }
\end{array}\right\}-\left\{\begin{array}{c}
\text { Saída de } \\
\text { massa nos } \\
\text { limites do } \\
\text { sistema }
\end{array}\right\}+\left\{\begin{array}{c}
\text { Geração } \\
\text { de massa } \\
\text { dentro do } \\
\text { sistema }
\end{array}\right\}-\left\{\begin{array}{c}
\text { Consumo } \\
\text { de massa } \\
\text { dentro do } \\
\text { sistema }
\end{array}\right\}
$$

Figura 14 - Representação da equação de balanço de material.

Fonte: Himmelblau, 1984 apud Santos, 2005, p. 141.

O balanço material deve ser realizado num determinado setor, equipamento ou processo, definido previamente em função do foco priorizado no programa de produção mais limpa. Segundo CEBDS (2003) as medições devem ser realizadas com a empresa funcionando e durante um período representativo, sendo os valores convertidos para o período de um ano.

O balanço material oferece grande confiabilidade, no entanto é muito trabalhoso de se fazer. $O$ fato de requerer um sistema fechado implica em uma contabilidade quantitativa rigorosa, onde todos os materiais precisam ser identificados, e os dados precisam ser acurados, de modo a fechar a equação do

\footnotetext{
${ }^{21}$ HIMMELBLAU, D. M. Engenharia Química: princípios e cálculos. 4 ed. rev. Rio de Janeiro:
} Prentice-Hall do Brasil, 1984. 
balanço. Devido a estas dificuldades, normalmente os balanços materiais são utilizados apenas quando um novo processo ou equipamento é projetado (POJASEK ${ }^{22}$, 1997 apud SANTOS, 2005).

Uma ferramenta que pode ser utilizada de forma alternativa, tendo em vista as dificuldades do balanço material, é a contabilidade de materiais. Essa ferramenta permite a quantificação dos materiais bastante próxima da realidade.

Segundo Santos (2005) a contabilidade de materiais, para o processo como um todo ou para unidades de processo individuais, baseia-se na premissa que todos os materiais que entram no processo precisam sair de uma forma ou de outra, como apresentado a seguir:

$$
(\text { Massa/volume })_{\text {entrada }}=(\text { Massa/volume })_{\text {saída }}
$$

Os valores medidos na saída englobam tanto o produto como os subprodutos. Caso todos os materiais tenham sido adequadamente contabilizados a razão da equação será próxima de 1 . Se a equação diferir significativamente de 1,0 desequilíbrio entre massa e volume significa que existem saídas não identificadas, que precisam ser investigadas. Se a razão da discrepância não for encontrada, a contabilidade de materiais pode ser efetuada para cada unidade específica de processo (SANTOS, 2005).

\subsection{Identificação das causas da geração de resíduos}

A quantificação das entradas e saídas das unidades de processo servirá de suporte para identificar os resíduos que estão sendo gerados ao longo do processo. Nesta etapa do programa de produção mais limpa procede-se a avaliação das causas da geração dos resíduos. Segundo o CEBDS (2003) devem ser feitas as seguintes perguntas: Por que? Como? Quando? Onde? os resíduos são gerados.

De forma a auxiliar essa análise o CNTL (2003a) aponta alguns fatores que podem contribuir para a produção de resíduos e emissões num processo industrial (Quadro 13).

\footnotetext{
${ }^{22}$ POJASEK, R. B. Materials Accounting and P2. Pollution Prevention Review. Summer issue, p. 91-101. 1997.
} 
Quadro 13 - Possíveis fatores responsáveis pela geração de resíduos nas indústrias.

\begin{tabular}{|c|c|}
\hline Fonte de Origem & $\begin{array}{l}\text { Fatores } \\
\end{array}$ \\
\hline Operacional & $\begin{array}{l}\text { - consumo de água e energia não conferidos; } \\
\text { - acionamento desnecessário ou sobrecargas de equipamentos; } \\
\text { - falta de manutenção preventiva; } \\
\text { - etapas desnecessárias no processo; } \\
\text { - falta de informações de ordem técnica e tecnológica. }\end{array}$ \\
\hline Matéria-prima & $\begin{array}{l}\text { - uso de matérias-primas de menor custo ou abaixo do padrão de qualidade; } \\
\text { - falta de especificação de qualidade; } \\
\text { - deficiência no suprimento; } \\
\text { - sistema inadequado de gerência de compras; } \\
\text { - armazenagem inadequada. }\end{array}$ \\
\hline Produtos & $\begin{array}{l}\text { - proporção inadequada entre resíduos e produtos; } \\
\text { - design impraticável do produto; } \\
\text { - embalagens inadequadas; } \\
\text { - produto composto por matérias-primas perigosas; } \\
\text { - produto de difícil desmontagem e reciclagem. }\end{array}$ \\
\hline Capital & $\begin{array}{l}\text { - escassez de capital para investimento em mudanças tecnológicas e de } \\
\text { processo; } \\
\text { - foco exagerado no lucro, sem preocupações na geração de resíduos e } \\
\text { emissões; } \\
\text { - baixo capital de giro. }\end{array}$ \\
\hline $\begin{array}{l}\text { Gerenciamento } \\
\text { dos resíduos }\end{array}$ & $\begin{array}{l}\text { - inexistência de separação de resíduos; } \\
\text { - desconsideração pelo potencial de reuso de determinados resíduos; } \\
\text { - não recuperação de energia nos produtos, resíduos e emissões; } \\
\text { - manuseio inadequado. }\end{array}$ \\
\hline $\begin{array}{l}\text { Recursos } \\
\text { Humanos }\end{array}$ & $\begin{array}{l}\text { - recursos humanos não qualificados; } \\
\text { - falta de segurança no trabalho; } \\
\text { - exigência de qualidade - treinamento inexistente ou inadequado; } \\
\text { - trabalho sob pressão; } \\
\text { - dependência crescente de trabalho eventual e terceirizado. }\end{array}$ \\
\hline $\begin{array}{l}\text { Fornecedores/ } \\
\text { parceiros } \\
\text { comerciais }\end{array}$ & $\begin{array}{l}\text { - compra de matérias-primas de fornecedores sem padronização; } \\
\text { - falta de intercâmbio com os parceiros comerciais; } \\
\text { - busca somente do lucro na negociação, sem preocupação com o produto final. }\end{array}$ \\
\hline $\begin{array}{l}\text { Know- } \\
\text { how/processo }\end{array}$ & $\begin{array}{l}\text { - utilização errada dos parâmetros de processo; } \\
\text { - uso de tecnologias de processo ultrapassadas }\end{array}$ \\
\hline
\end{tabular}

Fonte: Elaborado a partir de CNTL, 2003a, p. 25-26.

Uma ferramenta que pode ser utilizada nesta etapa é o diagrama de causa e efeito ou diagrama de Ishikawa (nome do seu idealizador) ou diagrama espinha de peixe (em virtude da sua forma). Essa ferramenta, apresentada na Figura 15, permite o mapeamento dos fatores principais e secundários que influenciam em um resultado, nesse caso a geração de resíduos. 


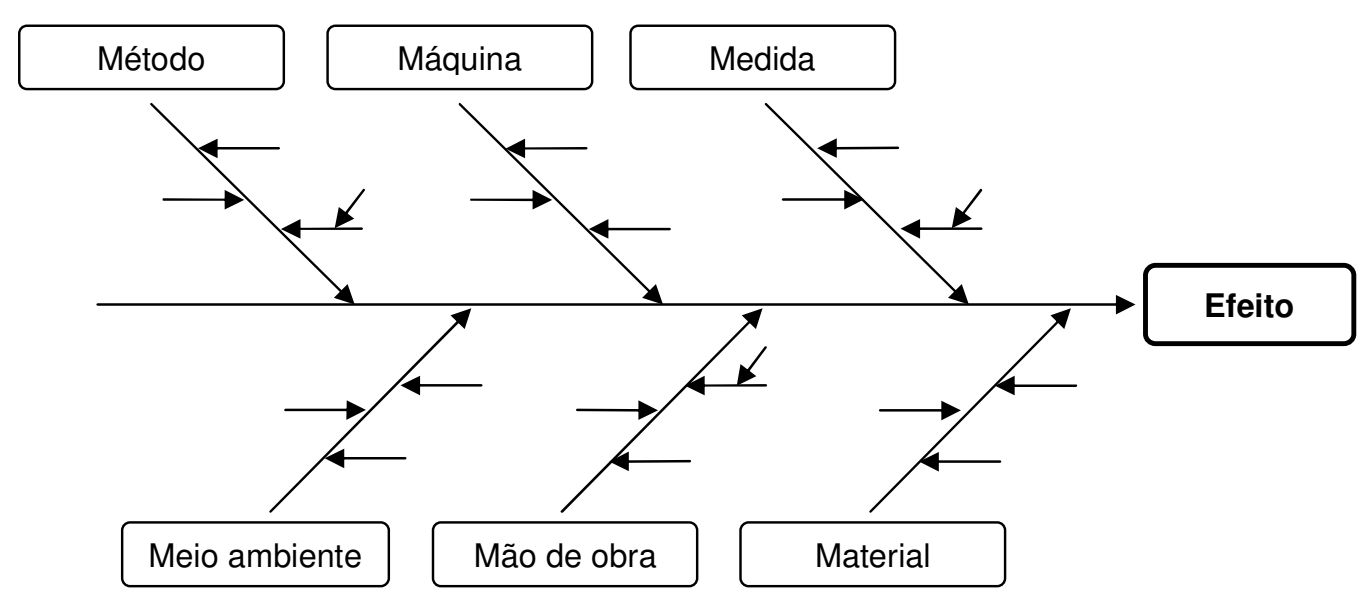

Figura 15 - Diagrama de causa e efeito. Fonte: Lugli, 2009.

Os grupos de causa geralmente utilizados no diagrama são: método, máquina, medida, meio ambiente, mão de obra e matéria-prima. A definição de cada um destes termos é apresentada a seguir (LUGLI, 2009; SANTOS, 2005):

- Método: a forma como o processo analisado é realizado, a organização das informações e do trabalho. Inclui questões como fluxo do processo, procedimentos de trabalho, procedimentos operacionais, etc.

- Máquina: inclui todos os maquinários, equipamentos, instrumentos de controle, bem como fatores relacionados, como ajustes, manutenção, etc.

- Medida: de que forma o resultado é medido, incluindo todas as variáveis que podem ser medidas, bem como fatores como disponibilidade, amostragem, reprodutibilidade e definição operacional.

- Meio ambiente: características físicas do ambiente de trabalho (temperatura, ruídos, iluminação, etc.), bem como das pessoas da organização (motivação, remuneração, relação entre diferentes níveis hierárquicos).

- Matéria-prima: inclui todas as entradas do processo e suas características, tais como fornecedores, modificações e variabilidade.

- Mão de obra: inclui todos os funcionários e gerentes e fatores a eles relacionados como conhecimento, treinamento, capacidade e atitude.

A construção do diagrama de causa e efeito se inicia com a determinação do resultado ou efeito indesejado do processo que se deseja investigar, a ser escrito do lado direito da linha horizontal. A partir dos seis grupos de causas, que devem ser 
indicados nas linhas diagonais maiores, são feitas perguntas-chave, cujas respostas (causas) são mostradas no diagrama nas linhas horizontais.

Santos (2005, p. 155) afirma que muitas questões podem ser levantadas, tais como: "a) O que está causando a perda? b) Porque a perda existe? c) Quando a perda se inicia e de onde ela vem? d) Porque a perda não é eliminada na fonte? e) O que acontece na etapa anterior ao surgimento da perda?".

As causas podem ser desmembradas em sub-causas (linhas diagonais menores), até o nível desejado.

\subsection{Identificação das opções de produção mais limpa}

Depois de identificadas as causas da geração dos resíduos o ecotime deverá buscar alternativas para solução do problema. As ações a serem priorizadas devem partir da redução na fonte, reciclagem interna e por último a reciclagem externa e os ciclos biogênicos. Esta seqüência de aplicação, já apresentada anteriormente (Figura 5 - Capítulo 3), possui maior vantagem ambiental. Cada uma destas estratégias é descrita a seguir (CNTL, 2003a; 2003c):

- Redução na fonte: contempla a modificação no produto e/ou no processo (mudança da matéria-prima, modificação tecnológica e boas práticas operacionais).

(4) Modificação no produto: as mudanças no produto são realizadas pelo fabricante de um produto com a intenção de reduzir os resíduos e emissões decorrentes do uso do mesmo. Elas incluem: mudanças nos padrões de qualidade; mudanças na composição do produto; durabilidade do produto; e, substituição do produto. As mudanças no produto podem levar a mudanças no design ou na composição. O novo produto pode assim ser construído para ser menos prejudicial ao meio ambiente durante todo o seu ciclo de vida: desde a extração da matéria-prima até a disposição final.

$\Leftrightarrow$ Mudança da matéria-prima: as mudanças em matérias-primas têm por objetivo reduzir ou eliminar os materiais perigosos que entram no processo de produção, que podem afetar a saúde e a segurança do 
trabalhador e obrigam à utilização de equipamentos específicos de proteção (EPI's). Também podem ser feitas mudanças nos materiais de entrada para evitar a geração de resíduos perigosos no processo. As mudanças do material de entrada incluem: purificação do material e substituição do material.

$\stackrel{\leftrightarrow}{M}$ Modificação tecnológica: as mudanças tecnológicas são orientadas para as modificações de processo e de equipamento para reduzir resíduos, efluentes e emissões, preliminarmente num ambiente de produção. As mudanças tecnológicas podem variar desde mudanças simples, que podem ser implementadas em questão de dias com baixo custo, até a substituição de processos que envolvem grandes custos. Estas incluem: mudanças no processo de produção; modificação do equipamento, layout ou tubulação; uso de automação; mudanças nas condições do processo, tais como taxas de fluxo, temperaturas, pressões e tempos de residência.

$\stackrel{\leftrightarrow}{4}$ Boas práticas operacionais: as boas práticas operacionais, também denominadas de melhor cuidado operacional ou de manutenção da casa (good housekeeping), implicam na adoção de medidas de procedimento, técnicas, administrativas ou institucionais que uma empresa pode implantar para minimizar os resíduos, efluentes e emissões. Boas práticas operacionais são freqüentemente implementadas com baixo custo. Estas práticas podem ser adotadas em todas as áreas, incluindo operações de produção, manutenção e de armazenagem de matérias-primas e dos produtos. Boas práticas operacionais incluem: práticas de gerenciamento e de pessoal; manuseio de material e práticas de inventário; treinamento de empregados; prevenção de perdas; separação de resíduos; práticas de contabilização de custos; e, programação da produção.

- Reciclagem interna: a reciclagem ou o reuso envolvem o retorno de um material residual ou para o processo que o originou, como um substituto para um material de entrada ou para outro processo como material de entrada.

- Reciclagem externa e ciclos biogênicos: as medidas já citadas (redução na fonte e reciclagem interna) devem ser adotadas preferencialmente quando da implantação de um programa de produção mais limpa. Somente quando tecnicamente descartadas deve-se optar por medidas de reciclagem de resíduos, efluentes e emissões fora da empresa. Isto pode acontecer na 
forma de reciclagem externa ou de uma reintegração ao ciclo biogênico (por exemplo: compostagem). A recuperação de matérias-primas de maior valor e sua reintegração ao ciclo econômico - como papel, aparas, vidros, materiais de compostagem - é um método menos reconhecido de proteção ambiental integrada através da minimização de resíduos.

Com o conhecimento dos processos e unidades de operação da empresa, bem como, das estratégias prioritárias para a implantação do programa de produção mais limpa, a equipe, conforme sugerido pelo CNTL (2003c), poderá realizar uma sessão de explosão de idéias, durante a qual são desenvolvidas idéias para produção mais limpa. A sessão poderá possuir um facilitador que assegure oportunidade a todos de compartilhar suas idéias.

Para que uma sessão de explosão de idéias seja eficiente é de vital importância que:

- Não haja constrangimentos hierárquicos que impeçam qualquer pessoa de compartilhar idéias.

- A sessão seja realizada em ambiente criativo e em horário que as pessoas possam pensar criativamente.

- Todas as idéias sejam consideradas uma oportunidade e adicionadas à lista, por mais ridícula que possa soar à primeira vista (CNTL, 2003c, p. 5758).

\subsection{Avaliação técnica, ambiental e econômica e seleção de oportunidades}

Escolhidas as opções de produção mais limpa deve-se proceder a sua avaliação técnica, econômica e ambiental. O CNTL (2003a) cita as principais questões que devem ser consideradas em cada uma das avaliações, apresentadas no Quadro 14. 
Quadro 14 - Questões a serem consideradas durante a avaliação técnica, ambiental e econômica das opções de produção mais limpa.

\begin{tabular}{|c|c|c|}
\hline Avaliação técnica & Avaliação ambiental & Avaliação econômica \\
\hline $\begin{array}{l}\text { - impacto da medida proposta } \\
\text { sobre o processo, } \\
\text { produtividade, segurança, etc.; } \\
\text { - testes de laboratório ou } \\
\text { ensaios quando a opção estiver } \\
\text { mudando significativamente o } \\
\text { processo existente; } \\
\text { - experiências de outras } \\
\text { companhias com a opção que } \\
\text { está sendo estudada; } \\
\text { - todos os funcionários e } \\
\text { departamentos atingidos pela } \\
\text { implementação das opções; } \\
\text { - necessidades de mudanças } \\
\text { de pessoal, operações } \\
\text { adicionais e pessoal de } \\
\text { manutenção, além do } \\
\text { treinamento adicional dos } \\
\text { técnicos e de outras pessoas } \\
\text { envolvidas. }\end{array}$ & $\begin{array}{l}\text { - a quantidade de resíduos, } \\
\text { efluentes e emissões que será } \\
\text { reduzida; } \\
\text { - a qualidade dos resíduos, } \\
\text { efluentes e emissões que } \\
\text { tenham sido eliminados - } \\
\text { verificar se estes contêm } \\
\text { substâncias tóxicas e } \\
\text { componentes reutilizáveis; } \\
\text { - a redução na utilização de } \\
\text { recursos naturais. }\end{array}$ & $\begin{array}{l}\text { - os investimentos necessários; } \\
\text { - os custos operacionais e } \\
\text { receitas do processo existente e } \\
\text { os custos operacionais e } \\
\text { receitas projetadas das ações a } \\
\text { serem implantadas; } \\
\text { - a economia da empresa com a } \\
\text { redução/eliminação de multas. }\end{array}$ \\
\hline
\end{tabular}

Fonte: Elaborado a partir de CNTL, 2003a, p. 33.

Através desta avaliação a empresa verificará se a opção de produção mais limpa escolhida é viável de ser adotada. A CETESB (2002) aconselha, inicialmente, a implementação das opções mais simples e de menor custo para então a empresa considerar modificações no processo que exigem pesquisas, testes, despesas de instalação e investimento de capital.

Pode-se considerar economicamente viável qualquer medida que ofereça uma redução de custo direto ou indireto relacionada à geração, manuseio e tratamento de resíduos ou de custos operacionais e que não envolva custos de investimentos iniciais. Como exemplo de opção simples cita-se as ações que envolvem boas práticas operacionais e de manutenção preventiva.

No caso das alterações que envolvam custos de investimento em capital e instalações iniciais o uso de índices de lucratividade deve ser adotado como, por exemplo, o cálculo do período de retorno do capital investido ou o valor presente líquido ou outros índices utilizados na matemática financeira, com a consideração da economia de custo relacionada à redução da geração de resíduos (CETESB, 2002).

Além disso, existem benefícios indiretos de difícil mensuração, como aqueles relacionados ao atendimento da legislação ambiental, imagem da empresa, saúde e segurança do trabalhador, custos indiretos e outros relacionados ao gerenciamento da empresa como um todo, que também devem ser avaliados na adoção das 
medidas de produção mais limpa. Segundo a CETESB (2002), apesar destes benefícios serem de difícil mensuração à curto prazo são significativos à empresa como um todo a médio e longo prazo.

Por fim, identificadas e avaliadas as oportunidades de produção mais limpa através dos critérios técnicos, ambientais e econômicos, selecionam-se as medidas viáveis de implantação.

\subsection{Plano de implantação e monitoramento}

O Plano de implantação tem por objetivo organizar as ações necessárias para que as oportunidades viáveis de produção mais limpa sejam efetivamente implantadas. O Plano deve conter um cronograma com os projetos a serem executados além dos recursos humanos e financeiros necessários.

De acordo com o CNTL (2003c) a implementação de oportunidades de produção mais limpa com a modificação ou aquisição de equipamentos novos não é essencialmente diferente de qualquer outro projeto de investimento e inclui os seguintes estágios: planejamento, design, aquisição e construção.

O CNTL (2003c, p. 34) sugere ainda que "juntamente com o plano de implementação deve ser planejado o sistema de monitoramento das medidas a serem implantadas." Nesta etapa, denominada de Plano de monitoramento, deve-se considerar:

- quando devem acontecer as atividades determinadas;

- quem é o responsável por estas atividades;

- quando são esperados os resultados;

- quando e por quanto tempo monitorar as mudanças;

- quando avaliar o progresso;

- quando devem ser assegurados os recursos financeiros;

- quando a gerência deve tomar uma decisão;

- quando a opção deve ser implantada;

- quanto tempo deve durar o período de testes;

- qual é a data de conclusão da implementação. 
A CETESB (2002) aponta a necessidade de avaliar periodicamente os benefícios e ganhos do ponto de vista ambiental e econômico advindos da implantação do programa, assim como os problemas e barreiras encontrados durante este processo.

Os indicadores definidos no início do programa serão uma ferramenta importante para avaliar e acompanhar o desempenho ambiental dos processos da empresa. Segundo a CETESB (2002), de posse destes dados, será possível quantificar os ganhos decorrentes da implementação do programa, como por exemplo:

- redução dos problemas ambientais;

- economia advinda da redução do consumo de água;

- redução dos custos relativos ao tratamento e disposição de poluentes;

- rendimentos obtidos em projetos de reciclagem;

- aumento da produtividade, dentre outros.

\subsection{Plano de Continuidade}

As ações de produção mais limpa devem ser contínuas, sendo assim, o objetivo do Plano de continuidade é a manutenção do programa de produção mais limpa na empresa para aprimoramento do seu processo produtivo, buscando a sustentabilidade.

O aprimoramento contínuo permitirá que a empresa se mantenha sempre atualizada com as inovações tecnológicas e as alterações da legislação ambiental, além de promover a melhoria da eficiência nos seus processos produtivos e assegurar o envolvimento de todo o corpo funcional e das partes interessadas no programa de P2 (CETESB, 2002, p. 13).

Depois de cada implementação de medidas de produção mais limpa novos objetivos e metas podem ser estabelecidos pelo ecotime, implicando na identificação de novas oportunidades e melhoria nos projetos em andamento.

$\mathrm{Na}$ eventualidade do programa não alcançar os resultados esperados, o ecotime deverá reavaliar todas as etapas que fazem parte do programa, identificar as causas do insucesso, propor medidas corretivas e reiniciar o programa (CETESB, 2002). 


\section{PROCESSO DE USINAGEM}

Neste capítulo pretende-se, de forma breve, apresentar os conceitos que envolvem o processo de usinagem de peças metálicas, com objetivo de avaliar os aspectos ambientais, notadamente quanto a geração de resíduos. Essas informações são necessárias para subsidiar a análise do processo de usinagem da empresa foco de avaliação dessa pesquisa.

Deve-se notar que são inúmeros e variados os processos de transformação de metais e ligas metálicas em peças, pode-se fundir, soldar, utilizar a metalurgia do pó ou usinar o metal a fim de se obter a peça desejada. A fundição é o processo de fabricação inicial, pois precede os demais. A usinagem, soldagem e conformação mecânica utilizam produtos semi-acabados (barras, chapas, perfis, tubos, etc.) como matéria prima que advém do processo de fundição (COSTA \& SANTOS, 2006).

Dentre esses inúmeros processos a usinagem tem grande importância na indústria metal-mecânica, pois grande parte dos produtos industrializados em alguma de suas etapas de produção sofre algum processo de usinagem. Stoeterau (2010) justifica essa importância a partir dos seguintes exemplos:

- $80 \%$ dos furos são realizados por usinagem;

- $100 \%$ dos processos de melhoria da qualidade superficial são feitos por usinagem;

- O comércio de máquinas-ferramentas representa uma das grandes fatias da riqueza mundial;

- $70 \%$ das engrenagens para transmissão de potência são produzidas a partir da usinagem;

- $90 \%$ dos componentes da indústria aeroespacial;

- $100 \%$ dos pinos médicos-odontológicos;

- 70\% das lentes de contato; e

- Lentes para CD player ou suas matrizes.

A Figura 16 mostra a classificação dos processos de fabricação, na qual se destaca a usinagem de interesse para este estudo. 


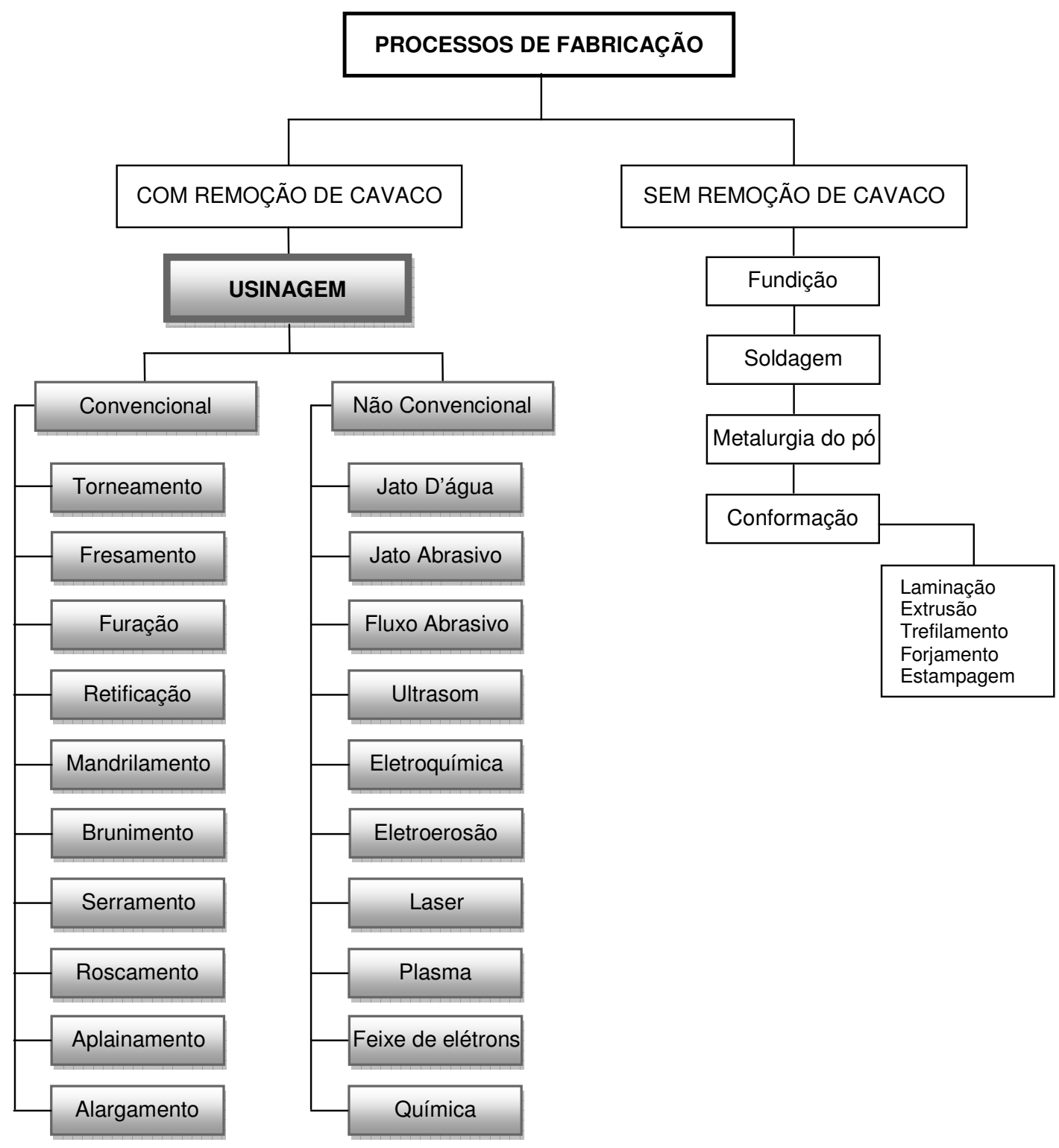

Figura 16 - Classificação dos processos de fabricação da indústria metalmecânica.

Fonte: Costa \& Santos (2006), p. 5.

$\mathrm{Na}$ figura pode-se notar que os processos de fabricação de metais e ligas metálicas são divididos de acordo com a remoção ou não de cavacos, a partir desta observação define-se usinagem como a operação que confere à peça forma, dimensões ou acabamento, ou ainda a combinação de qualquer desses três, através da remoção de material sob a forma de cavaco (STOETERAU, 2010; MACHADO et. al., 2009). 
O cavaco é a porção de material da peça retirada pela ferramenta ${ }^{23}$ e caracterizada por apresentar forma geométrica irregular (MACHADO et. al., 2009). Trata-se, portanto, de um dos resíduos gerados no processo de usinagem para obtenção de uma determinada peça.

Segundo Trent $^{24}$ (1985 apud MACHADO et. al. 2009, p. 3), "a usinagem é reconhecidamente o processo de fabricação mais popular do mundo, transformando em cavacos algo em torno de $10 \%$ de toda a produção de metais, e empregando dezenas de milhões de pessoas em todo o mundo."

De acordo com Groover ${ }^{25}$ (2007 apud ARAUJO, 2010, p. 76), "os processos de usinagem são os mais versáteis e acurados processos de manufatura, capazes de cumprir a tarefa de produzir peças geométricas e superfícies variadas." A Figura 17, a seguir, ilustra uma peça bruta e suas transformações até a obtenção do produto final.

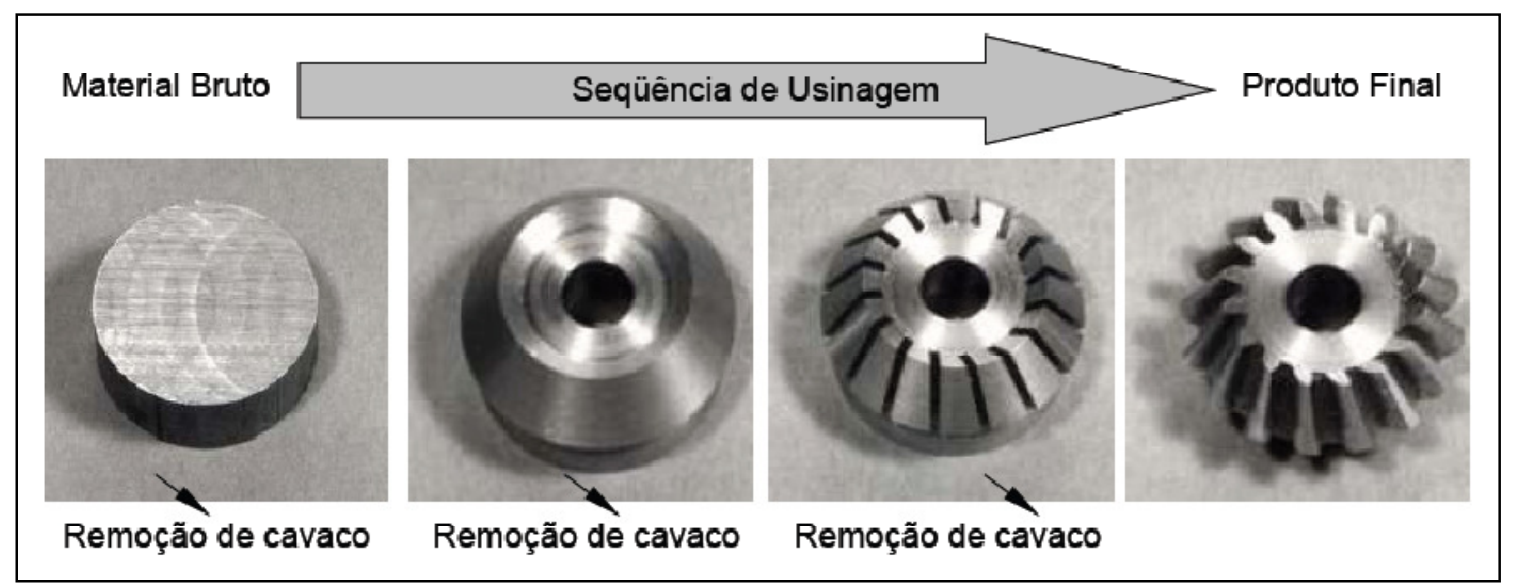

Figura 17 - Sequência de formação da peça no processo de usinagem.

Fonte: Stoeterau (2010), p. 10.

Na operação de usinagem ocorre a interação entre a peça, matéria-prima que irá sofrer a transformação, e a ferramenta. A fixação de ambas é realizada por um dispositivo de fixação, no caso da peça, e pelo porta-ferramenta, no caso da ferramenta. A máquina ferramenta tem por objetivo proporcionar os movimentos de velocidade, avanço e a força necessária ao processo (Figura 18).

\footnotetext{
${ }^{23}$ Ferramenta é tudo o que realiza uma operação de usinagem (STOETERAU, 2010).

${ }^{24}$ TRENT, E. M. Metal cutting. 2. ed. Londres:Butterworths \& Co., 1985.

${ }^{25}$ GROVER, M. P. Fundamentals of Modern Manufacturing. Hoboken, NJ: John Wiley, 2007, $1002 \mathrm{p}$.
} 


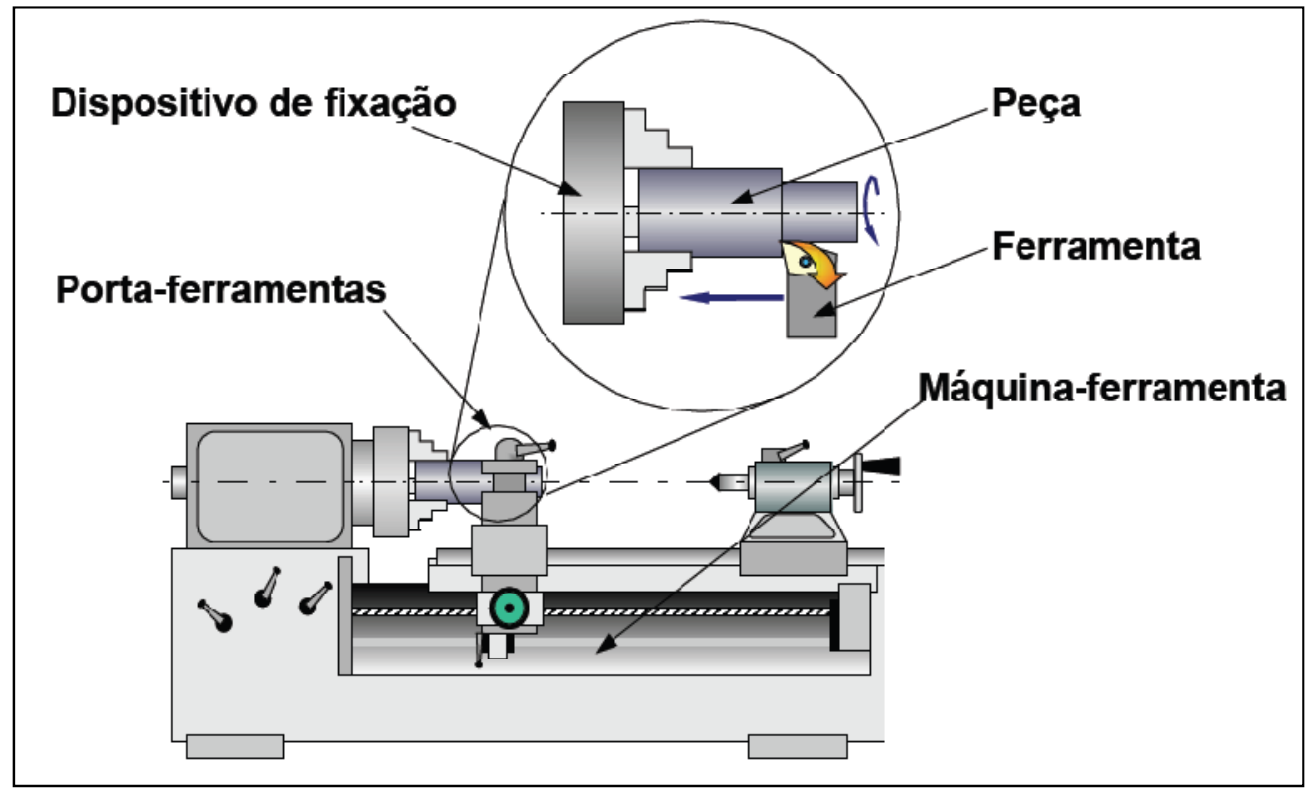

Figura 18 - Grandezas do processo de usinagem.

Fonte: Stoeterau (2010), p. 32.

Para que a peça atinja as dimensões, formas e o acabamento desejados, movimentos de avanço e corte entre a peça e a ferramenta são necessários, conforme demonstrado na Figura 19.

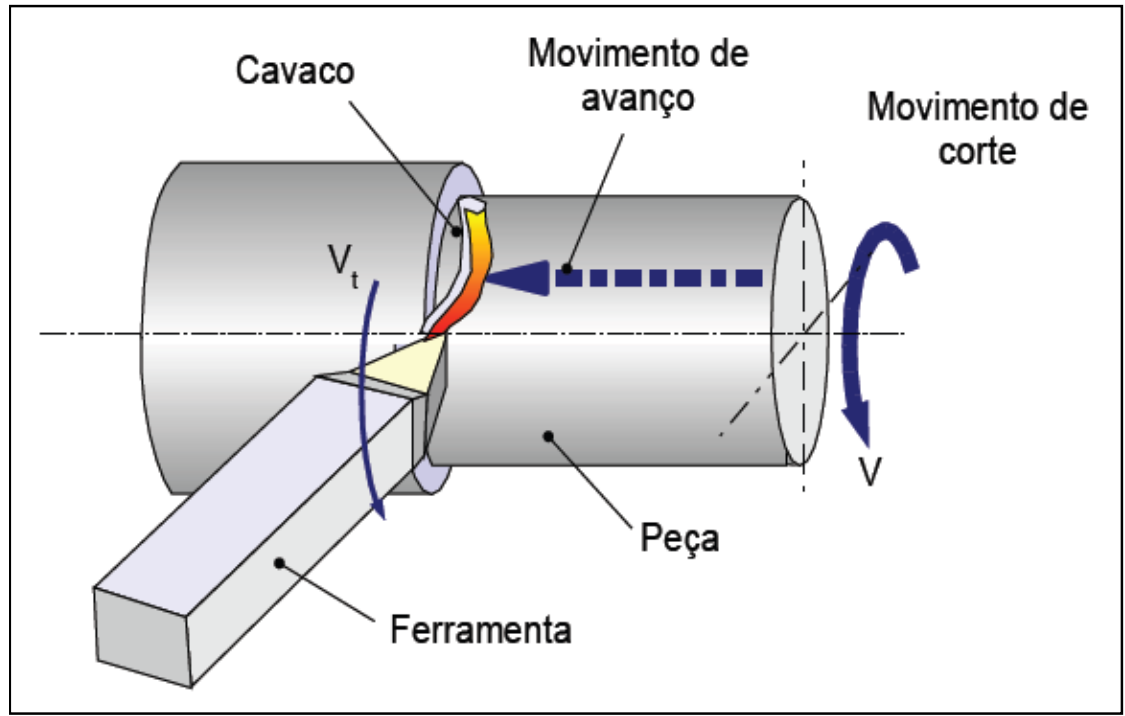

Figura 19 - Cinemática geral dos processos de usinagem. Fonte: Stoeterau (2010), p. 34.

Os movimentos representados na figura anterior são responsáveis pela formação do cavaco, sendo que Costa \& Santos (2006, p. 30) os definem da seguinte maneira: 
- Movimento de corte: movimento entre a peça e a ferramenta, no qual sem o movimento de avanço, origina uma única retirada do cavaco;

- Movimento de avanço: movimento entre a peça e a ferramenta que juntamente com movimento de corte origina a retirada contínua de cavaco;

- Movimento efetivo: movimento resultante dos movimentos de corte e avanço realizado ao mesmo tempo.

\subsection{Operações de usinagem}

As principais operações da usinagem convencional são descritas a seguir:

- Torneamento: é um processo mecânico de usinagem destinado a obtenção de superfícies de revolução com o auxílio de uma ou mais ferramentas monocortantes. Para tanto, a peça gira em torno do seu eixo enquanto a ferramenta de corte realiza os movimentos de avanço longitudinal e/ou transversal (COSTA \& SANTOS, 2006; MACHADO et. al., 2009). Nas figuras 20, 21 e 22 são apresentadas algumas variantes do processo.
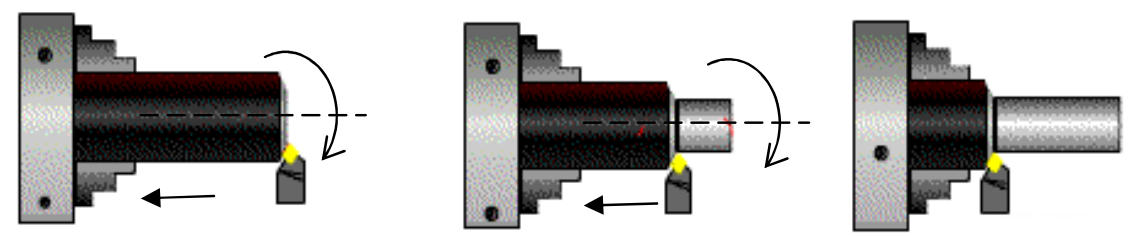

Figura 20 - Torneamento cilíndrico externo. Fonte: Adaptado de CIMM (2010).
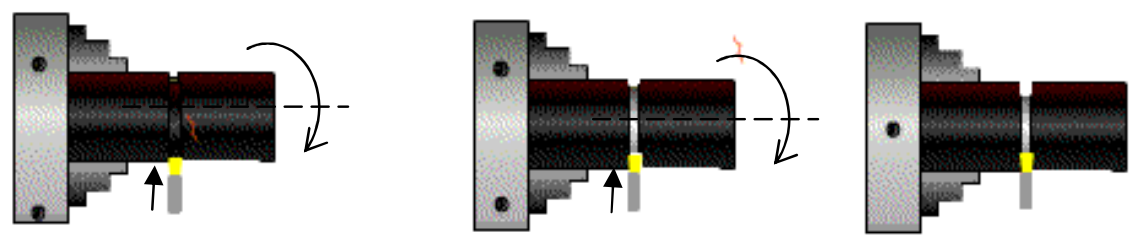

Figura 21 - Sangramento radial. Fonte: Adaptado de CIMM (2010). 

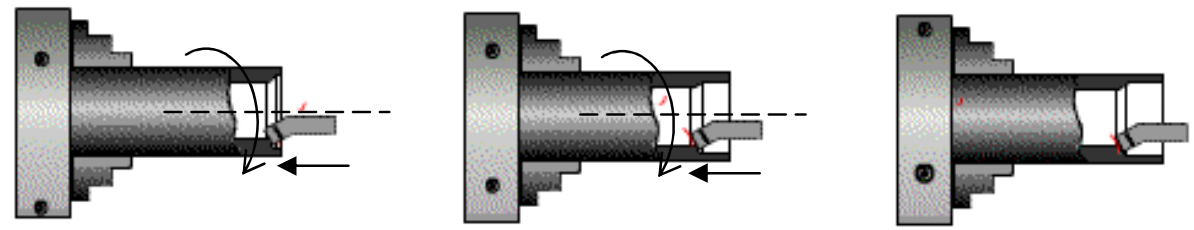

Figura 22 - Torneamento cilíndrico interno. Fonte: Adaptado de CIMM (2010).

- Furação: é um processo mecânico de usinagem destinado a obtenção de um furo geralmente cilíndrico numa peça, com auxílio de uma ferramenta multicortante. Para tanto a ferramenta ou a peça se desloca segundo uma trajetória retilínea, coincidente ou paralela ao eixo principal da máquina (COSTA \& SANTOS, 2006). Na Figura 23 apresenta-se um exemplo do processo de furação.
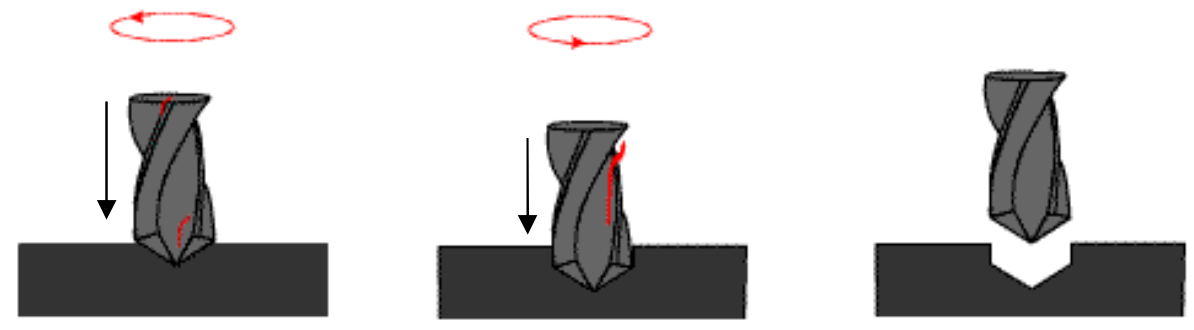

Figura 23 - Furação em cheio.

Fonte: Adaptado de CIMM (2010).

- Alargamento: é um processo mecânico variante da furação destinado ao alargamento de furos cilíndricos ou cônicos, com auxílio de ferramenta normalmente multicortante. Para tanto, a ferramenta ou a peça gira e a ferramenta ou a peça se desloca segundo uma trajetória retilínea, coincidente ou paralela ao eixo de rotação da ferramenta. $O$ alargamento pode ser de acabamento (Figura 24) ou de desbaste (Figura 25) (COSTA \& SANTOS, 2006; CIMM, 2010). 

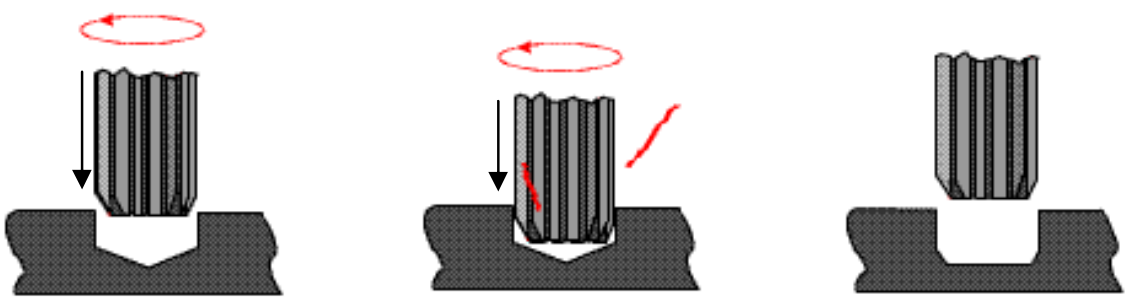

Figura 24 - Alargamento cilíndrico de acabamento. Fonte: Adaptado de CIMM (2010).
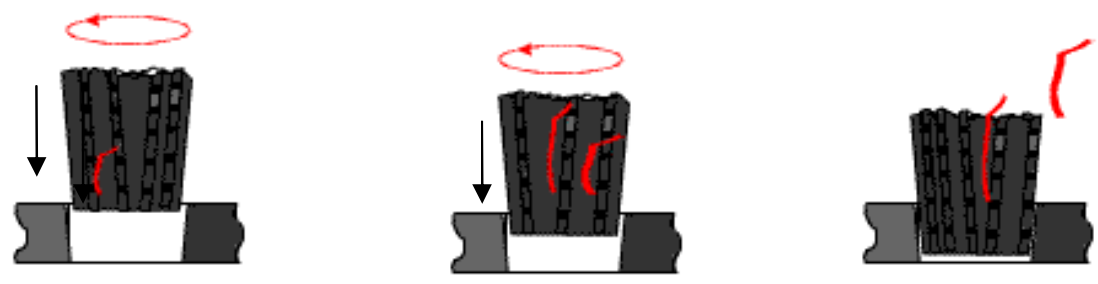

Figura 25 - Alargamento cônico de desbaste. Fonte: Adaptado de CIMM (2010).

- Fresamento: esta operação é reconhecida pela versatilidade na produção de geometrias diversas, além de garantir elevadas taxas de remoção de material, visto que a ferramenta (fresa) possui múltiplas arestas de corte. Nesse grupo de operações, a ferramenta gira enquanto a peça, presa à mesa, é responsável pelos movimentos de avanço longitudinal e transversal, na Figura 26 são apresentadas variantes do processo (MACHADO et. al., 2009).
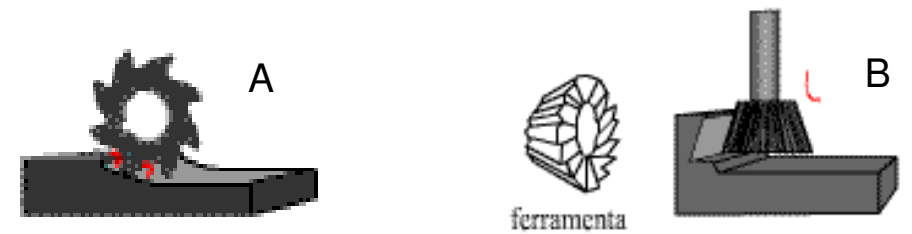

Figura 26 - (A) Fresamento tangencial; (B) Fresamento frontal angular. Fonte: Adaptado de CIMM (2010).

- Brochamento: é comumente empregado quando se deseja produzir furos com formas diferentes da cilíndrica. A ferramenta (brocha) é tracionada e a passagem de dentes sucessivos provoca a abertura de um furo inicial, para o perfil desejado. Elevada qualidade dimensional e geométrica pode ser conseguida em componentes produzidos em massa, sendo que formas 
externas também podem ser obtidas (MACHADO et. al., 2009). A Figura 27 ilustra o brochamento interno.
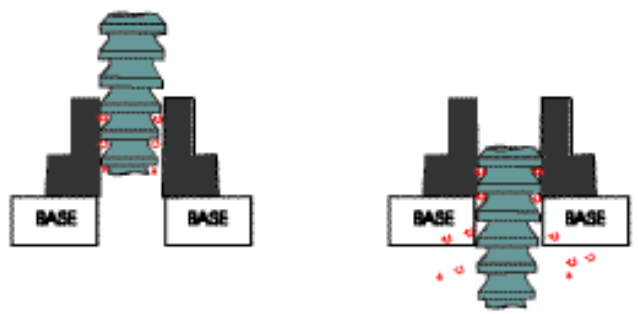

Figura 27 - Brochamento interno. Fonte: Adaptado de CIMM (2010).

- Mandrilamento: é realizado em um equipamento específico (mandriladora), similar a uma fresadora de grande porte. Nessa operação, utilizada principalmente no acabamento interno de furos cilíndricos e com perfis especiais, a ferramenta é dotada dos movimentos de corte e avanço, enquanto a peça permanece estática. É particularmente interessante para a usinagem de peças de grandes dimensões e assimétricas (MACHADO et. al., 2009).

- Roscamento: a abertura de roscas é uma operação bastante diversificada e que pode ser realizada com o uso de dispositivos manuais ou por meio de máquinas-ferramentas (tornos, fresadora, rosqueadeiras, etc.), dependendo principalmente da taxa de produção esperada, mas também das dimensões da rosca. Roscas externas podem ser produzidas por cossinetes (conhecidos como tarraxas) ou por ferramentas de perfil único ou múltiplo. Já roscas internas podem ser produzidas utilizando jogos de machos ou ferramentas de perfil único ou múltiplo (MACHADO et. al., 2009).

- Retificação: diferentemente dos processos anteriores que utilizam uma ferramenta de corte de geometria definida, na retificação o material da peça é removido por meio da ação de grãos abrasivos. Esses grãos são partículas não metálicas, extremamente duras, com arestas que apresentam forma e orientação irregular (MACHADO et. al., 2009).

Nessa operação a ferramenta gira em torno de seu próprio eixo além de poder executar movimento de translação. A peça a usinar também pode 
movimentar-se. O processo é de alta precisão dimensional e proporciona grau de acabamento superior (polimento) (CIMM, 2010). As Figuras 28 e 29 apresentam duas variações deste processo.
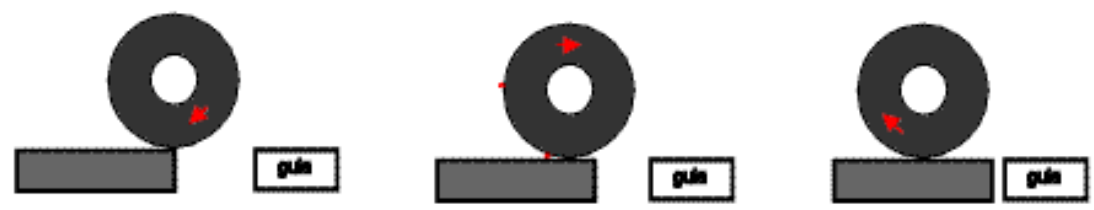

Figura 28 - Retificação plana.

Fonte: Adaptado de CIMM (2010).
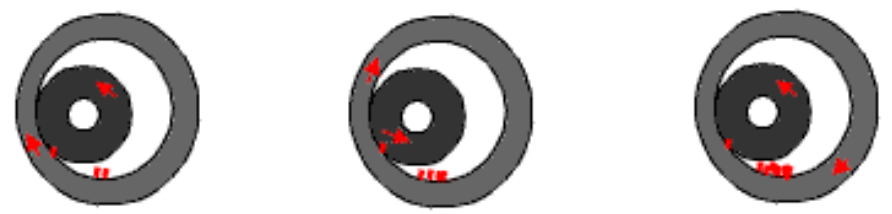

Figura 29 - Retificação interna.

Fonte: Adaptado de CIMM (2010).

\subsection{Fluidos de Corte}

No processo de usinagem dos metais a maior parte da potência consumida é convertida em calor próximo a aresta cortante da ferramenta e muitos problemas técnicos e econômicos são causados direta ou indiretamente por conta desse aquecimento (TRENT ${ }^{26}, 1988$ apud MACHADO et. al., 2009).

Quando se empregam maiores velocidades de corte tem-se maior geração de calor devido ao atrito entre a peça e a ferramenta, causando maior desgaste das arestas cortantes da ferramenta e, por conseqüência, redução da sua vida útil. Já no caso inverso, com menores velocidades podem ocorrer problemas de acabamento e produtividade.

Estudos de pesquisadores como Frederick Winslow Taylor, em 1894, constataram que com a aplicação de grande quantidade de água na região de corte,

\footnotetext{
${ }^{26}$ TRENT, E. M. Metal cutting and the tribology of seizure: I Seizure in metal cutting. Wear, v. 128,
} p. $65-81,1988$. 
era possível aumentar a velocidade de corte em 33\%, sem prejuízo para a vida da ferramenta (RUFINO ${ }^{27}$, 1977 apud MACHADO et. al., 2009). De acordo com Catai et. al. (2003) essa constatação impulsionou o estudo e o desenvolvimento de vários tipos de fluídos de corte ao longo dos anos, principalmente, nas últimas décadas.

No processo de usinagem as principais funções dos fluídos de corte são (MACHADO et. al., 2009):

- Lubrificação a baixas velocidades de corte;

- Refrigeração a altas velocidades de corte;

- Remoção dos cavacos da zona de corte; e

- Proteção da máquina-ferramenta e da peça contra a oxidação.

Como lubrificante, o fluído de corte contribui para reduzir o atrito e a geração de calor, formando uma película entre a ferramenta e a peça, impedindo quase totalmente o contato direto entre os mesmos, como também reduz a área de contato ferramenta-cavaco. Segundo Biermann (2008) a redução do coeficiente de atrito na região de contato ferramenta-cavaco contribui para a melhoria do rendimento da máquina.

Machado et. al.(2009, p. 159), cita ainda que o fluído de corte:

[...] também pode restringir o caldeamento (união) do cavaco com a superfície de saída da ferramenta se aditivos apropriados forem acrescentados. A eficiência da lubrificação dependerá das propriedades do fluído, como características de molhabilidade, viscosidade, oleosidade e resistência do filme.

Já como refrigerante o fluído de corte favorece a dissipação do calor da região de corte, reduzindo assim a temperatura da ferramenta, evitando que ela perca suas características de corte, e da peça, evitando deformações causadas pelo calor. Quanto ao cavaco, a refrigeração atua na redução da força necessária para que seja cortado.

Como protetor contra a oxidação, o fluído de corte protege a peça, a ferramenta e o cavaco, contribuindo para o bom acabamento final do trabalho. Além disso, como conseqüência da sua aplicação em forma de jato, afasta as aparas (cavaco) deixando limpa a zona de corte e facilitando o controle visual da qualidade do trabalho (BIERMANN, 2008).

Quanto à classificação de fluidos de corte não há uma padronização. Embora seja eventualmente descrito na literatura a utilização de fluidos de corte gasosos e

\footnotetext{
${ }^{27}$ RUFINO, R. T. Fluidos de corte. In: Fundamentos da usinagem dos metais. São Paulo: Blucher,
} 1977. 
sólidos, os líquidos representam a grande maioria das aplicações em operações de usinagem (MACHADO et. al., 2009). Os fluidos líquidos são agrupados em óleos, emulsões e soluções, conforme detalhado no Quadro 15.

Quadro 15 - Classificação e vantagens dos fluidos de corte líquidos.

\begin{tabular}{|c|c|c|c|}
\hline Classificação & Categoria & Base & Vantagens \\
\hline \multirow{4}{*}{$\begin{array}{l}\text { Isentos de } \\
\text { água }\end{array}$} & \multirow{4}{*}{$\begin{array}{l}\text { Óleos } \\
\text { Integrais }\end{array}$} & $\begin{array}{c}\text { Mineral } \\
\text { (derivados de petróleo) }\end{array}$ & \multirow{4}{*}{$\begin{array}{l}\text { - Não são corrosivos; } \\
\text { - Apresentam longa duração se mantidos } \\
\text { limpos. }\end{array}$} \\
\hline & & $\begin{array}{c}\text { Sintética } \\
\text { (ésteres, diésteres) }\end{array}$ & \\
\hline & & Vegetal (canola) & \\
\hline & & Mistos & \\
\hline \multirow{3}{*}{$\begin{array}{l}\text { A base de } \\
\text { água }\end{array}$} & \multirow{2}{*}{ Emulsões } & Mineral & \multirow{2}{*}{$\begin{array}{l}\text { - Alto poder refrigerante; } \\
\text { - Alto poder umectante; } \\
\text { - Utilizados em operações de alta } \\
\text { velocidade. }\end{array}$} \\
\hline & & Semi-sintética & \\
\hline & Soluções & Sintética & $\begin{array}{l}\text { - Não absorve os óleos contaminantes que } \\
\text { vazam das máquinas (são insolúveis); } \\
\text { - Possui excepcional resistência biológica. }\end{array}$ \\
\hline
\end{tabular}

Fonte: Elaborado a partir de Biermann (2008), p. 14-17.

Além das funções já apresentadas os fluidos de corte devem ainda possuir as seguintes propriedades: ser antiespumante, anticorrosivo, antioxidante, antidesgaste e antisolda, ter boa umectação, capacidade de absorção de calor e transparência, ser inodoro, não provocar irritações na pele, ser compatível com o meio ambiente, ter baixa variação de viscosidade quando utilizado (MACHADO et. al., 2009).

A maioria dessas propriedades é conferida por meio da adição de aditivos aos fluidos, sendo os principais (COSTA \& SANTOS, 2006):

- Antiespumantes: evitam a formação de espuma que poderia impedir a boa visão da região de corte e comprometer o efeito de refrigeração do fluido;

- Anticorrosivos: protegem a peça, a ferramenta e a máquina-ferramenta da corrosão (são produtos à base de nitrito de sódio);

- Antioxidantes: tem a função de impedir que o óleo se deteriore quando em contato com o oxigênio no ar;

- Detergentes: reduzem a deposição de lodo, lamas e borras (composto de magnésio, bário, cálcio, entre outros);

- Emulsificantes: são responsáveis pela estabilização da emulsão;

- Biocidas: substâncias ou misturas químicas que inibem o crescimento de microorganismos; 
- Agentes EP (extrema pressão): para operações mais severas de corte, eles conferem aos fluidos de corte uma lubricidade melhorada para suportarem elevadas temperaturas e pressões de corte reduzindo o contato da ferramenta com o material. Os principais agentes EP são à base de enxofre, cloro e fósforo.

Apesar dos benefícios dos fluidos de corte como a redução do custo total de fabricação ou aumento da taxa de produção, deve-se notar que os mesmos acarretam custos associados à sua aquisição, armazenamento, preparo, controle em serviço e, finalmente, descarte.

Com suficiente cuidado, os fluidos isentos de água não precisam ser substituídos nas máquinas. A quantidade necessária de recarga em virtude das perdas através dos cavacos e das peças é suficiente para garantir em grande parte a sua qualidade. Já no caso dos fluídos à base de água maiores problemas são causados. As emulsões precisam ser substituídas regularmente nas máquinas, o que resulta em grandes quantidades de fluido para ser posteriormente disposto (SOKOVIC \& MIJANOVIC, 2001).

Segundo Oliveira \& Alves (2007) as perdas de fluido de corte ocorridas durante o processo de usinagem podem ser bastante prejudiciais e custosas à empresa. Os autores afirmam que essas perdas ocorrem nos seguintes pontos:

- No sistema de manufatura pela vaporização na usinagem,

- Na saída de cavacos e peças da máquina,

- Nos componentes da máquina, tais como dispositivos de fixação e manuseio,

- No vácuo,

- Nos sistemas de pressurização do ar,

- Na formação de gotas e vazamentos, sendo o vazamento um fator crítico que contribui para a perda e, em alguns casos, para as influências negativas nos sistemas hidráulicos da máquina.

Segundo Byrne 28 (1996 apud OLIVEIRA \& ALVES, 2007, p. 130), "cerca de $30 \%$ do consumo total anual de fluido de corte é perdido através da remoção do sistema pelos meios mencionados acima, o que torna evidente a necessidade de se encontrar métodos eficazes para combater tais perdas".

\footnotetext{
${ }^{28}$ BYRNE, G. Usinagem em ambiente limpo: não se trata apenas de higiene. Máquinas e Metais, São Paulo, p. 67-80, abril, 1996.
} 
De acordo com Novaski \& Dörr ${ }^{29}$ (1999 apud Catai et. al. 2003), a utilização de uma quantidade cada vez menor de fluído na região de corte, de modo a não comprometer a usinagem, tem grande importância no cotidiano das indústrias. Os gastos com refrigeração representam, em média, 17\% dos custos de manufatura, um valor expressivo, se comparado aos destinados à ferramenta, que apresenta, em média, de 2 a 4\%, além das despesas de manutenção do sistema e separação do cavaco do fluido de corte para uma posterior refundição.

Embora seja, praticamente, muito difícil eliminar por completo o emprego de fluidos de corte, Batzer \& Sutherland ${ }^{30}$ (1998 apud MACHADO et. al., 2009) e Graham $^{31}$ (2000 apud MACHADO et. al., 2009) recomendam que, nos casos em que sua aplicação é questionável (ou quando as perdas são passíveis de amortização), a questão ambiental seja colocada em primeiro plano.

Quanto a questão ambiental deve-se notar que os fluidos de corte são potencialmente perigosos ao ambiente de trabalho e ao ambiente natural. A Figura 30 a seguir apresenta os fatores ecológicos associados aos fluidos de corte.

De acordo com Sokovic \& Mijanovic (2001) operadores de máquinas são afetados pelo contato com várias substâncias presentes no fluido de corte. Sua saúde pode ser prejudicada pelo contato da pele ou por ingestão da substância, como também, pela respiração ou pelo efeito irritante da névoa de óleo e vapores.

Oliveira \& Alves (2007) mencionam que existem substanciais evidências de aumento do risco de câncer, em diferentes órgãos do corpo humano, associado com a utilização dos fluidos de corte.

O tipo e quantidade dos constituintes químicos dos fluidos podem variar para as diferentes classes, alguns destes componentes são considerados carcinogênicos, como por exemplo a N-nitroamina. Dentre os diversos tipos de fluidos de corte o que tem se revelado mais agressivo à saúde do operador é o óleo integral. O solúvel é o menos agressivo. Porém, através dos poucos estudos realizados sobre os efeitos dos fluidos à saúde do operador, é prematuro concluir que todos os membros da classe dos óleos solúveis estão livres de ter algum risco carcinogênico, pois deve-se considerar que o óleo solúvel contém muitos ingredientes encontrados nos óleos integrais, mas em diferentes concentrações (OLIVEIRA \& ALVES, 2007, p. 131).

\footnotetext{
${ }^{29}$ NOVASKI, O.; DÖRR, J. Usinagem quase a seco. Revista Máquinas \& Metais. 406, p. 34-41, nov/1999.

${ }^{30}$ BATZER, S.; SUTHERLAND, J. The dry cure for coolants ills. Cutting Tool Engineering, p. 34-44, jun/1998.

${ }^{31}$ GRAHAM, D. Dry out. Cutting Tool Engineering, p. 56-65, mar/2000.
} 


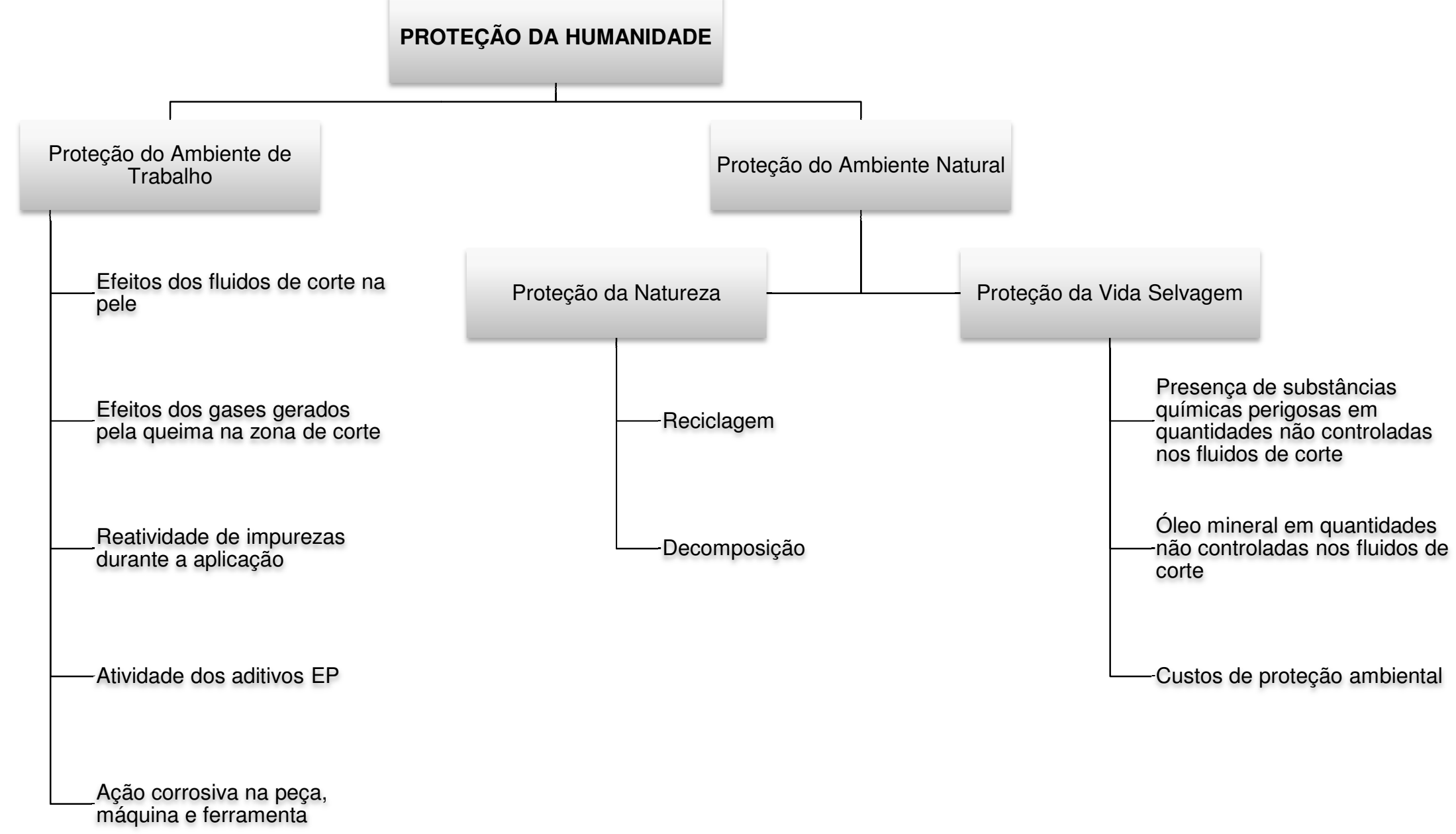

Figura 30 - Caracterização dos fatores ecológicos dos fluidos de corte.

Fonte: Adaptado de Socovic \& Mijanovic (2001), p.184. 
Quanto aos impactos ao ambiente natural deve-se mencionar que após o uso os fluidos de corte devem ser descartados. Sua disposição final pode ser realizada pela própria indústria ou por uma empresa especializada em disposição de resíduos. Caso este descarte não seja realizado de maneira adequada o resultado será a poluição do solo, água e ar.

Deve-se notar que os fluidos de corte quando estão novos representam um pequeno risco, mas durante sua vida útil ao longo do processo de usinagem ocorrem mudanças na sua composição. As substâncias secundárias que podem ser formadas são: produtos de reações originados durante o processo, corpos estranhos e microorganismos que são agregados ao fluido de corte; substancias essas que alteram os riscos oferecidos ao ambiente (SOKOVIC \& MIJANOVIC, 2001; OLIVEIRA \& ALVES, 2007).

Diante dos problemas que podem ser causados tanto no ambiente de trabalho como no ambiente natural, uma alternativa que tem sido apresentada por alguns fabricantes de fluidos de corte é o retorno dos produtos de base vegetal (biodegradáveis), uma vez que tais produtos apresentam maior compatibilidade com a pele humana e reduzida tendência á formação de vapor, fumaça e névoa, contribuindo assim para uma melhor qualidade do ar e limpeza do ambiente de trabalho (KURODA ${ }^{32}, 2006$ apud MACHADO et. al., 2009).

Além disso, possuem ponto de fulgor superior ao de óleos minerais de mesma viscosidade, o que reduz o risco de incêndios. Da mesma forma que os óleos minerais, os óleos vegetais também podem ser descartados por meio de queima, mas são menos poluentes ao meio ambiente e apresentam matéria-prima renovável (KURODA, 2006 apud MACHADO et. al., 2009, p. 166).

De maneira geral Oliveira \& Alves (2007) afirmam que para garantir-se um menor impacto dos fluidos de corte à saúde dos operadores e à qualidade do meio ambiente, gerentes e operadores devem estar cientes de todos os cuidados que são indispensáveis na sua aplicação, usando das medidas de precaução fornecidas pelo fabricante e órgãos ambientais, evitando assim a ocorrência de resultados desagradáveis.

\footnotetext{
${ }^{32}$ KURODA, M. Aumentando a lucratividade com óleos vegetais. O mundo da usinagem. 2 ed. São Paulo, 2006.
} 


\section{MATERIAIS E MÉTODOS}

\subsection{Tipo de pesquisa}

O procedimento técnico utilizado na pesquisa foi do tipo Estudo de $\mathrm{Caso}^{33}$, realizado numa empresa de usinagem. A forma de abordagem foi quali-quantitativa, no qual se enfatizou a necessidade de reconhecer a peculiaridade do objeto pesquisado, ou seja, o gerenciamento de resíduos sólidos industriais, de forma a permitir seu amplo e detalhado conhecimento, para a proposição de melhorias, priorizando ações de prevenção.

O Estudo de Caso desenvolveu-se sob uma pesquisa exploratória, visando proporcionar maior familiaridade com o problema para torná-lo explicito. Segundo Silva e Menezes (2001) a pesquisa exploratória envolve levantamento bibliográfico, entrevistas com pessoas que tiveram experiências práticas com o problema pesquisado e análise de exemplos que estimulem a compreensão.

Embora o Estudo de Caso não permita a generalização dos resultados, pode fornecer subsídios para o estabelecimento de comparações com outras situações similares. No trabalho, em questão, as experiências vivenciadas pela empresa alvo e as melhorias propostas no gerenciamento dos resíduos sólidos poderão ser úteis a outras indústrias do segmento de usinagem.

\subsection{Coleta de dados}

As informações da empresa alvo do estudo, quanto ao seu processo produtivo e o gerenciamento de resíduos, foram coletadas diretamente com os funcionários durante visitas a planta. Para a condução da coleta dos dados utilizaram-se formulários (Apêndice A e B) elaborados a partir dos manuais e guias de produção mais limpa.

\footnotetext{
${ }^{33}$ Cf. SILVA \& MENEZES, 2001, p. 21
} 
A coleta dos primeiros dados foi realizada através do formulário de pesquisa denominado Levantamento Preliminar (Apêndice A). Neste primeiro contato com a empresa o objetivo era de familiarizar-se com a mesma e seu processo produtivo. Desta forma foram coletadas informações gerais e quanto aos aspectos ambientais e operacionais.

Os dados específicos foram coletados com auxílio do formulário de pesquisa denominado Levantamento Detalhado (Apêndice B). Foram realizadas diversas visitas na empresa para coleta e refinamento dos dados para realizar o diagnóstico do gerenciamento dos resíduos sólidos e para a elaboração dos fluxogramas quali e quantitativos, balanço de massa e verificação das causas da geração dos resíduos. A partir da análise destas informações foram propostas as melhorias no gerenciamento dos resíduos sólidos e apontadas as oportunidades para sua minimização.

\subsection{Caracterização da empresa objeto do estudo}

O Estudo de Caso foi realizado numa indústria, localizada no município de São Carlos/SP, neste estudo denominada apenas como Indústria $\mathrm{X}$, para manter o sigilo das informações fornecidas.

Fundada há 14 anos, a Indústria $\mathrm{X}$, desenvolve e presta serviços de usinagem, retificação e laminação de roscas em peças de precisão em aços e materiais não ferrosos. Seus principais clientes são as empresas do mercado nacional do segmento da linha branca de eletrodomésticos e de máquinas e implementos agrícolas.

Trata-se de uma empresa de pequeno porte, com 68 (sessenta e oito) funcionários, sendo 62 (sessenta e dois) no setor produtivo e 6 (seis) no administrativo. Opera 24 horas por dia em três turnos, de segunda a sexta-feira.

$A$ Indústria $X$ encontra-se licenciada junto ao órgão de meio ambiente do Estado, a Companhia Ambiental do Estado de São Paulo - CETESB, e possui Certificado de Qualidade ISO 9001 desde o ano 2000. O Sistema de Gestão de Qualidade é mantido e atualizado por meio de auditorias periódicas. 
Não existe na empresa um setor exclusivo para tratar dos assuntos ambientais. Essas questões são de responsabilidade da Coordenadora de Gestão de Pessoas e Qualidade.

Quanto ao gerenciamento dos resíduos sólidos a empresa informou que não possui Plano de Gerenciamento de Resíduos Sólidos (PGRS) e Inventário de Resíduos Sólidos. Apesar disso mantém registro dos resíduos que são vendidos.

A empresa produz uma cartela variada de peças, conforme a solicitação dos clientes, sendo que a peça mais produzida, com um total de 4.000 peças/dia, destina-se a uma empresa da linha branca de eletrodomésticos. Em consenso com a indústria o processo de produção desta peça, denominada no estudo como peça A, foi escolhido para avaliação da geração dos resíduos.

\subsection{Justificativa da escolha da empresa alvo}

A Indústria $X$ foi escolhida levando-se em consideração os seguintes fatores:

- Interesse em participar da pesquisa e abertura para a disponibilização das informações referente ao seu processo industrial.

- Por tratar-se de empresa de pequeno porte ${ }^{34}$, pois se constatou na literatura que empresas desse porte costumam apresentar maiores dificuldades para 0 desenvolvimento de práticas de gestão ambiental por disporem de recursos financeiros mais limitados que empresas maiores, além de normalmente contarem com uma falta de estrutura organizacional adequada.

- Por tratar-se da análise de um processo produtivo de usinagem, que segundo Oliveira \& Alves (2007) é um dos processos mais utilizados na manufatura em geral, tornando, portanto, a pesquisa deste segmento relevante.

\footnotetext{
${ }^{34}$ Para definição de empresas de pequeno porte consultar no Glossário "Critérios de classificação de empresas".
} 


\subsection{Delimitação do foco de estudo}

A Indústria $X$ produz diariamente vários tipos de peças conforme a solicitação dos clientes. Para a realização de um levantamento detalhado optou-se por delimitar o foco do estudo a uma peça que fosse produzida diariamente e em maior quantidade pela empresa.

A peça escolhida, denominada neste estudo como peça $A$, destina-se ao setor de eletrodomésticos da linha branca e apresenta uma produção de 4.000 peças/dia.

Para a peça A foram avaliados os tipos de resíduos gerados, suas quantidades e forma de gerenciamento (segregação, acondicionamento, armazenamento, transporte e destinação final). Os dados levantados limitaram-se aos processos internos da empresa, ou seja, não foram visitados fornecedores de insumos e matérias-primas, clientes e empresas que compram os resíduos. 


\section{RESULTADOS E DISCUSSÕES}

Neste capítulo são avaliados e discutidos os dados obtidos junto a Indústria $X$ quanto ao gerenciamento dos resíduos sólidos gerados na fabricação da peça $A$. Para a coleta dos dados na empresa foi utilizada a metodologia de produção mais limpa, apresentada no Capítulo 5. Deve-se mencionar que essa metodologia foi utilizada para avaliar o gerenciamento dos resíduos sólidos para a posterior proposição de melhorias priorizando a prevenção da geração de resíduos.

\subsection{Descrição do processo produtivo}

A Indústria $X$ opera na prestação de serviços de usinagem, retificação e laminação de roscas em peças de precisão em aços e materiais não ferrosos. Dentre os diversos produtos fabricados na empresa a peça $A$, com uma produção média de 4.000 peças/dia, é a mais expressiva em termos de quantidade. A Figura 31 apresenta um resumo das suas etapas de produção.

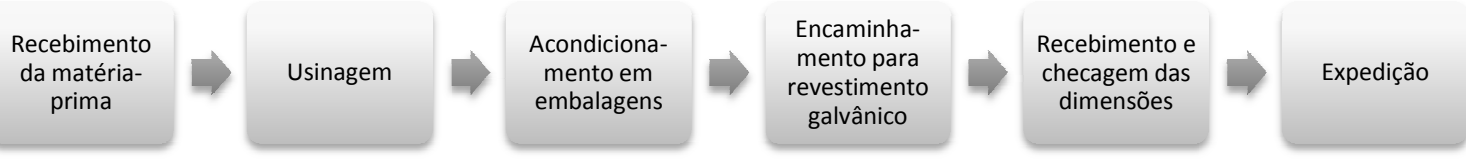

Figura 31 - Etapas do processo de produção da peça A.

A matéria-prima para fabricação da peça trata-se de barras de aço com diâmetro de $12 \mathrm{~mm}$ e comprimento de 3 metros. No recebimento das barras são conferidos por amostragem (a cada 5 barras) o diâmetro e comprimento das barras, aquelas que não atendem as especificações são devolvidas para o fabricante. As barras conformes são armazenadas em área específica, separadas de acordo com suas características e recebem uma ficha de controle, onde é informado o tipo do aço, quantidade e peso.

A usinagem completa da peça ocorre em um torno CNC com o emprego de fluído de corte de base vegetal. Na operação de torneamento combinam-se dois 
movimentos: rotação da peça e movimento de avanço da ferramenta, como já explicado no Capítulo 6. No caso dos tornos CNC a usinagem é realizada por comandos numéricos computadorizados, ou seja, a trajetória da ferramenta de corte e rotação da peça são pré-programadas, resultando em maior flexibilidade, precisão e uniformidade na manufatura em comparação com as máquinas-ferramenta convencionais (manuais ou semi-automáticas).

Após este processo o operador retira manualmente possíveis rebarbas da peça e confere suas dimensões críticas. Tendo em vista que a empresa trabalha com usinagem de precisão as dimensões críticas são de décimos de milímetros. As peças usinadas são encaminhadas a uma empresa de galvanoplastia, em embalagens retornáveis, onde são revestidas por uma camada de níquel/cromo. No retorno das mesmas, após o processo de revestimento, suas dimensões são novamente conferidas sendo então armazenadas em embalagens plásticas retornáveis para expedição ao cliente.

Dentre as etapas do processo de produção, apresentadas anteriormente na Figura 31, a de maior interesse quanto ao aspecto da geração de resíduos é a usinagem da peça. Isso se deve a não geração de resíduos durante as etapas de recebimento da matéria-prima, acondicionamento da peça, checagem das dimensões e expedição, principalmente porque a empresa utiliza embalagens plásticas retornáveis para acondicionar o produto acabado. Já a etapa de revestimento galvânico apesar de gerar resíduos, não foi avaliada por ser realizada por outra empresa.

Sendo assim, o foco de avaliação para identificação dos resíduos gerados e seu manuseio foi centrado na etapa de usinagem da peça $A$. O fluxograma qualitativo, que apresenta as entradas e saídas na operação de torneamento para a produção da peça A é apresentado a seguir. 


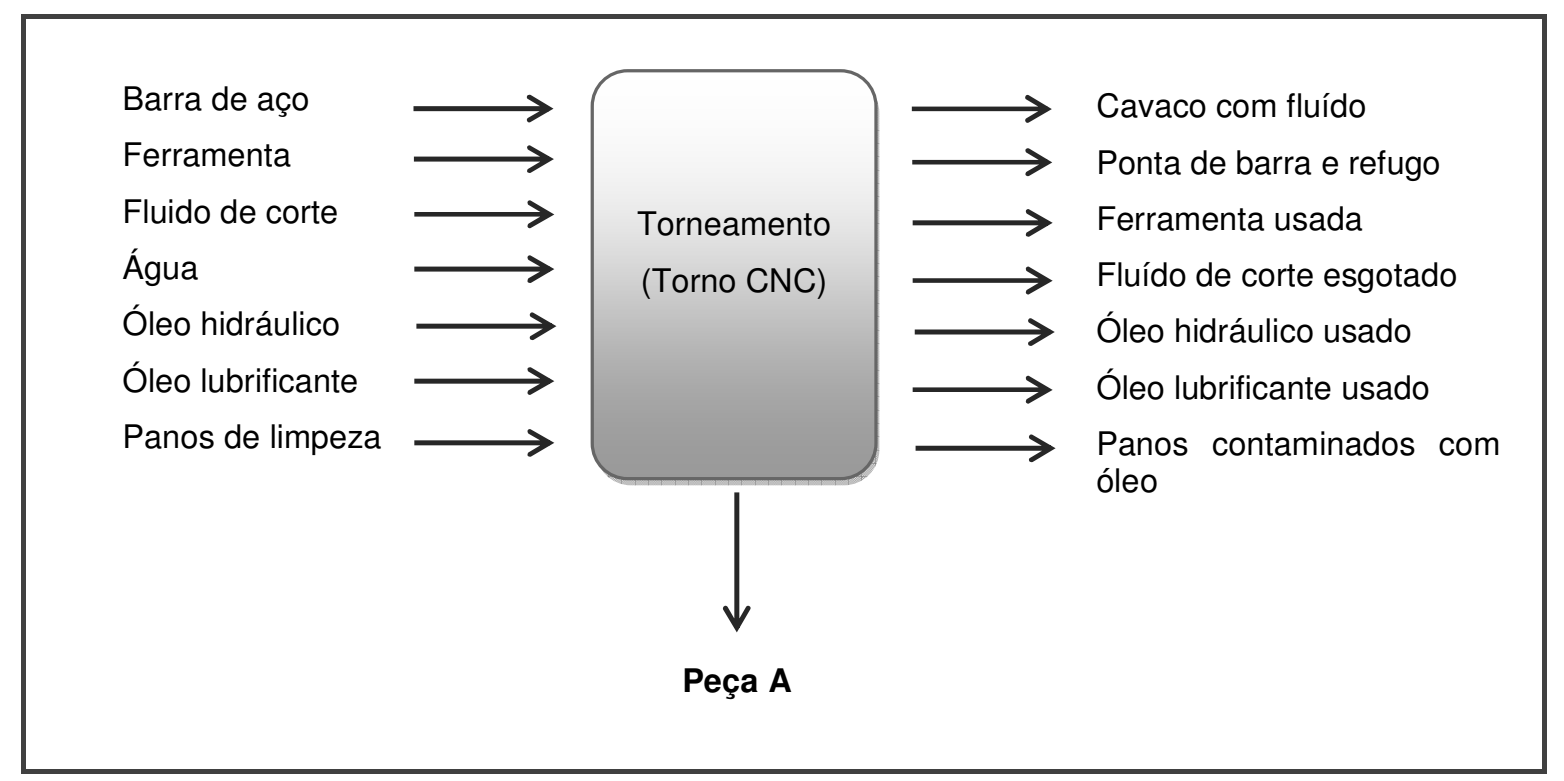

Figura 32 - Fluxograma qualitativo da etapa de usinagem da peça A.

O cavaco é gerado no processo de usinagem da peça e trata-se de aparas de aço. Durante a usinagem utiliza-se fluído de corte que auxilia neste processo através da lubrificação e refrigeração da zona de contato entre a peça e a ferramenta. Desta forma, juntamente com o cavaco perde-se parte do fluído.

$\mathrm{Na}$ empresa é utilizado fluído de corte a base de óleo de éster vegetal. Conforme verificado na empresa o fluído é diluído em água e utilizado nas máquinas na concentração de $8 \%$. Existe um funcionário na empresa responsável pela conferência desta concentração e pelos ajustes necessários, dentre eles a reposição do fluído diluído. Nas reposições o fluído é adicionado na concentração de $2 \%$, pois a maior parte das perdas ocorre pela evaporação da água.

A empresa que fornece o fluído de corte presta assistência técnica a Indústria, realizando visitas periódicas ou quando solicitada. Nestas visitas a condição do fluído é verificada e quando necessário adicionam-se bactericidas.

O óleo hidráulico tem por objetivo a transmissão de força as peças da máquina-ferramenta evitando desgastes e garantindo os movimentos de avanço. Os óleos hidráulicos têm vida útil longa, sendo apenas substituídos em caso de contaminações ou oxidações. Conforme informado pelo funcionário da empresa, no último ano este óleo não foi substituído nem reposto.

Já o óleo lubrificante é utilizado para reduzir o atrito e lubrificar as engrenagens e motor da máquina-ferramenta. Este óleo quando saturado é substituído. 
As pontas de barra são geradas em função da variação dos comprimentos das barras de aço. Quando as pontas de barra possuem comprimento suficiente para a fabricação da peça $A$, estas são separadas e usinadas em torno manual. Já quando o comprimento não é suficiente ou a peça usinada não atende as dimensões críticas é classificada como refugo.

\subsection{Gerenciamento dos resíduos}

Os resíduos gerados na empresa para a fabricação da peça $A$, conforme elencados na Figura 32, são: cavaco com fluído de corte, pontas de barra e refugo, ferramenta usada, fluído de corte esgotado, óleo hidráulico usado, óleo lubrificante usado e panos de limpeza contaminados com óleo.

Para a caracterização e classificação dos resíduos gerados consultou-se a norma ABNT NBR 10.004/2004. O resultado encontrado é apresentado no quadro a seguir.

Quadro 16 - Classificação dos resíduos de acordo com a NBR 10.004/2004.

\begin{tabular}{|l|c|c|c|c|}
\hline Resíduo gerado & Classe & $\begin{array}{c}\text { Consta no } \\
\text { Anexo }\end{array}$ & $\begin{array}{c}\text { Código de } \\
\text { identificação }\end{array}$ & Característica \\
\hline Óleo de corte e usinagem usado & I & A & F330 & Tóxico \\
\hline Óleo lubrificante usado & I & A & F130 & Tóxico \\
\hline Óleo hidráulico usado & I & A & F230 & Tóxico \\
\hline Pontas de barra e refugo & II & H & A005* & Não perigoso \\
\hline Ferramenta usada & II & H & A005* & Não perigoso \\
\hline Cavaco com fluído de corte & I & - & - & Tóxico \\
\hline Pano contaminado com óleo & I & - & - & Tóxico \\
\hline
\end{tabular}

Nota: *Resíduo de sucata de metais não ferrosos

O cavaco e os panos usados foram classificados como Classe I, pois estão misturados com resíduos enquadrados como perigosos, no caso do primeiro com fluído de corte e o segundo com os óleos utilizados na empresa.

Com a identificação dos resíduos gerados partiu-se para a sua quantificação. Seguiu-se a metodologia do programa de produção mais limpa para elaborar o fluxograma quantitativo (Figura 33), utilizando como base de cálculo os valores 
quantitativos de resíduos gerados, de matérias-primas consumidas e de produtos fabricados para o período de 1 (um) ano.

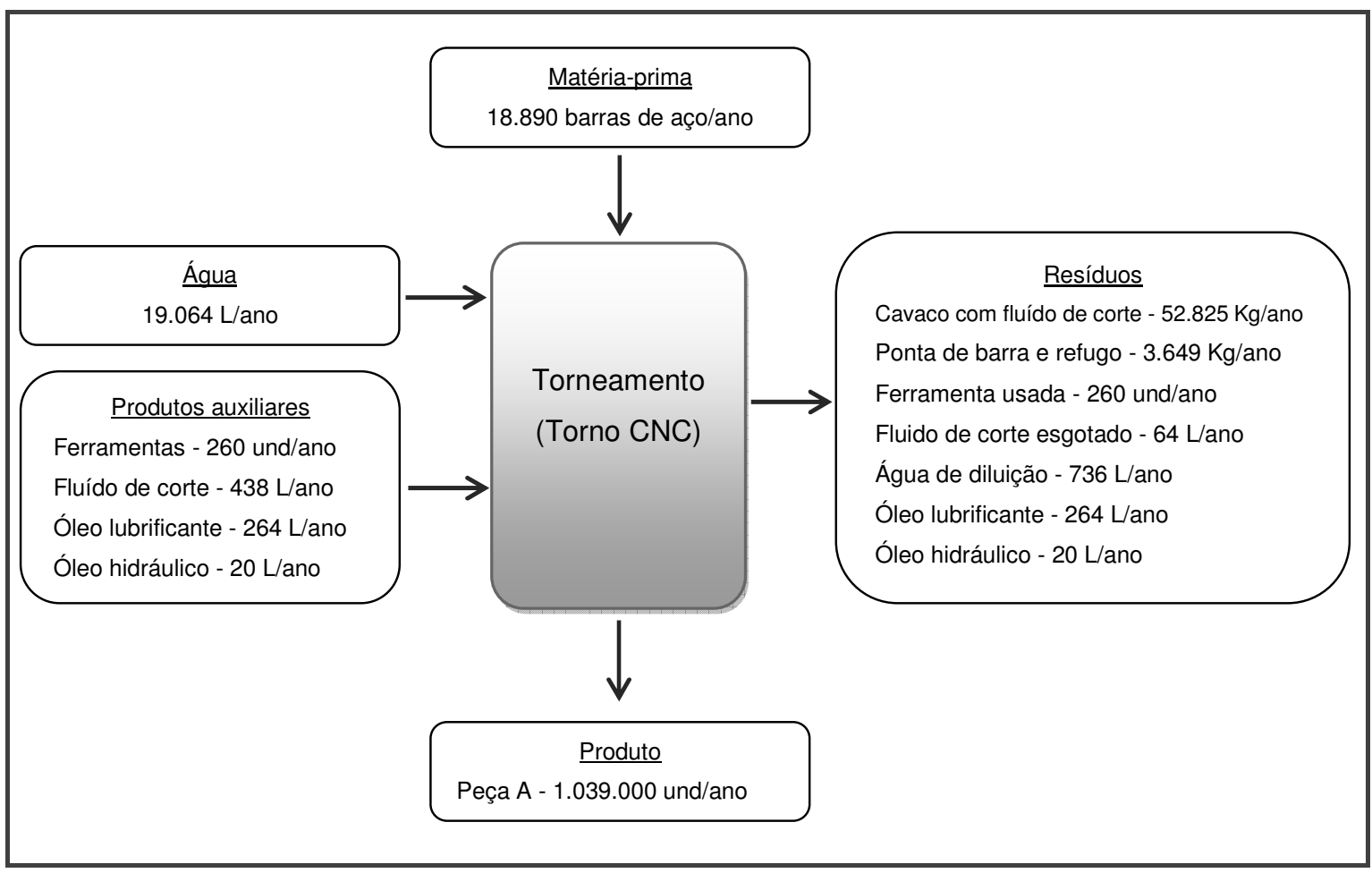

Figura 33 - Fluxograma quantitativo da etapa de usinagem da peça A.

Para a quantificação dos materiais levou-se em consideração as informações prestadas pela empresa e uma medição realizada in loco (Foto 1), quando foram pesadas as quantidades de cavaco e pontas de barra. Deve-se mencionar ainda que alguns valores foram estimados. Com base em todas estas informações foi realizado um balanço de massa das entradas e saídas (Tabela 1). 


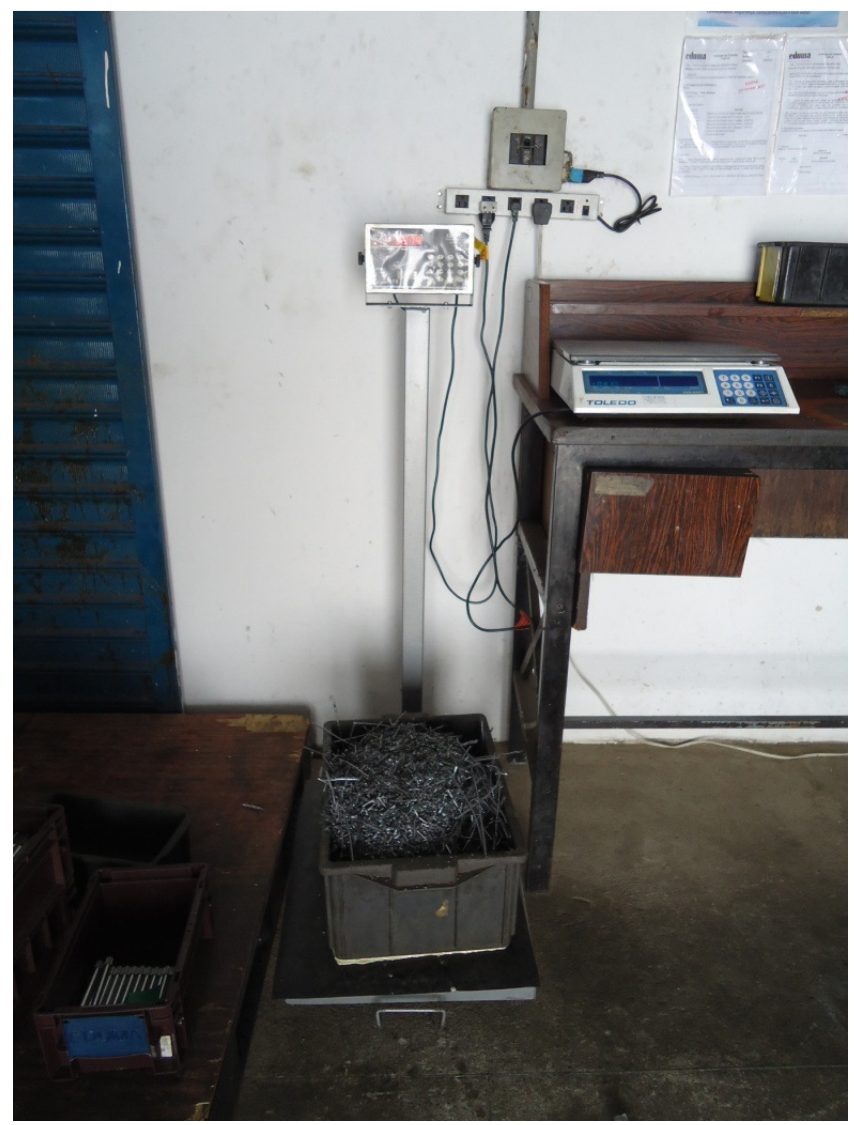

Foto 1 - Pesagem do cavaco na empresa.

Tabela 1 - Quantidade em massa das entradas e saídas.

\begin{tabular}{|c|c|c|c|}
\hline Entradas & $\begin{array}{c}\text { Quantidade } \\
\text { (Kg/ano) }\end{array}$ & Saídas & $\begin{array}{c}\text { Quantidade } \\
\text { (Kg/ano) }\end{array}$ \\
\hline Aço & 78.717 & Peça A & 25.975 \\
\hline Fluído de corte & 416 & Ponta de barra & 3.649 \\
\hline Água & 19.064 & Cavaco com fluído, sendo: & \\
\hline Óleo hidráulico & 18 & Cavaco & 49.093 \\
\hline \multirow[t]{8}{*}{ Óleo lubrificante } & 237 & Fluído de Corte & 355 \\
\hline & & Água & 2.598 a 4.156 \\
\hline & & Fluído esgotado, sendo: & \\
\hline & & Fluído de corte & 61 \\
\hline & & Água & 736 \\
\hline & & Óleo hidráulico & 18 \\
\hline & & Óleo lubrificante & 237 \\
\hline & & $\begin{array}{l}\text { Água perdida por } \\
\text { evaporação }\end{array}$ & 14.172 a 15.730 \\
\hline
\end{tabular}

Nota: Densidades consideradas Fluído de corte: $0,95 \mathrm{~g} / \mathrm{cm}^{3}$ Água: $1,00 \mathrm{~g} / \mathrm{cm}^{3}$
Óleo hidráulico: $0,887 \mathrm{~g} / \mathrm{cm}^{3}$

Óleo lubrificante: $0,898 \mathrm{~g} / \mathrm{cm}^{3}$ 
A Tabela a seguir apresenta os valores em massa dos resíduos gerados e sua porcentagem em relação a produção total de resíduos para a produção da peça A.

Tabela 2 - Porcentagem dos resíduos/emissões gerados.

\begin{tabular}{lcc}
\hline Resíduo & Quantidade (Kg/ano) & Porcentagem (\%) \\
\hline Cavaco & 49.093 & 67,7 \\
Ponta de barra e refugo & 3.649 & 5,0 \\
Fluído de Corte & 416 & 0,6 \\
Água de diluição & 4.113 & 5,6 \\
Água evaporada & 14.951 & 20,6 \\
Óleo lubrificante usado & 237 & 0,3 \\
Óleo hidráulico & 18 & 0,2 \\
\hline TOTAL & $\mathbf{7 2 . 4 7 7}$ & $\mathbf{1 0 0 \%}$ \\
\hline
\end{tabular}

O cavaco é o resíduo gerado em maior quantidade na empresa $(67,7 \%)$, conforme se pode observar na Tabela 2, sendo que juntamente com a ponta de barra totalizam $72,2 \%$ de resíduos de sucata de aço. A somatória dos resíduos oleosos por sua vez representam $1,1 \%$ do que é gerado.

Nota-se também que grande parte da água que entra no processo para diluição do fluído de corte é evaporada (20,6\%), tendo em vista o calor gerado na interface de corte entre a peça e a ferramenta. Estima-se que de $75 \%$ a $85 \%$ da água de reposição diária, utilizada na diluição do fluido de corte (concentração $2 \%$ ), evapora, o que totaliza em média 57 L/dia.

Durante as visitas na empresa observou-se também a forma de manuseio de cada um destes resíduos, sendo a seguir apresentadas as informações coletadas. $O$ cavaco assim que formado é armazenado em bandeja metálica no próprio torno (Foto 2). Sob esta bandeja encontra-se o tanque de armazenamento do fluído de corte.

Quando o depósito mostrado na Foto 2 atinge sua capacidade o operador retira os cavacos e acondiciona-os em tambores de metal localizados dentro da área da empresa e próximos ao torno (Foto 3 e Foto 4). 


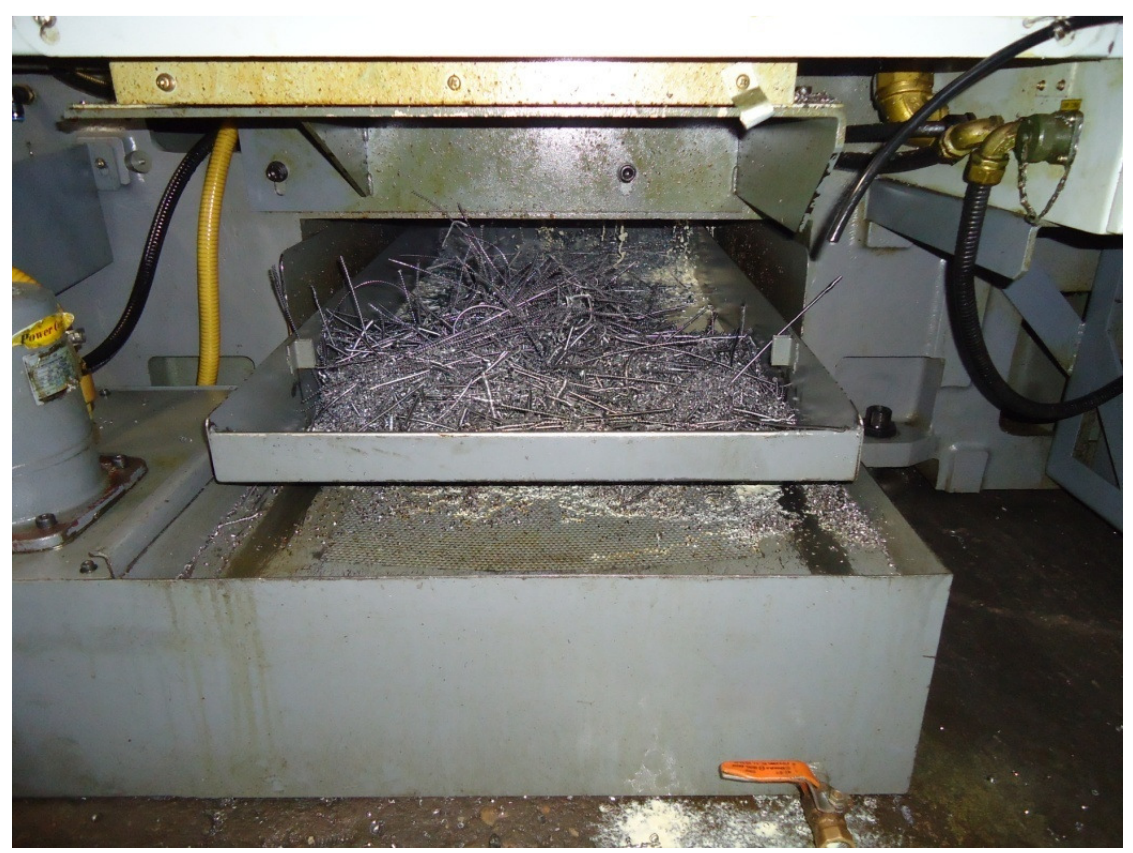

Foto 2 - Bandeja de armazenamento de cavaco.

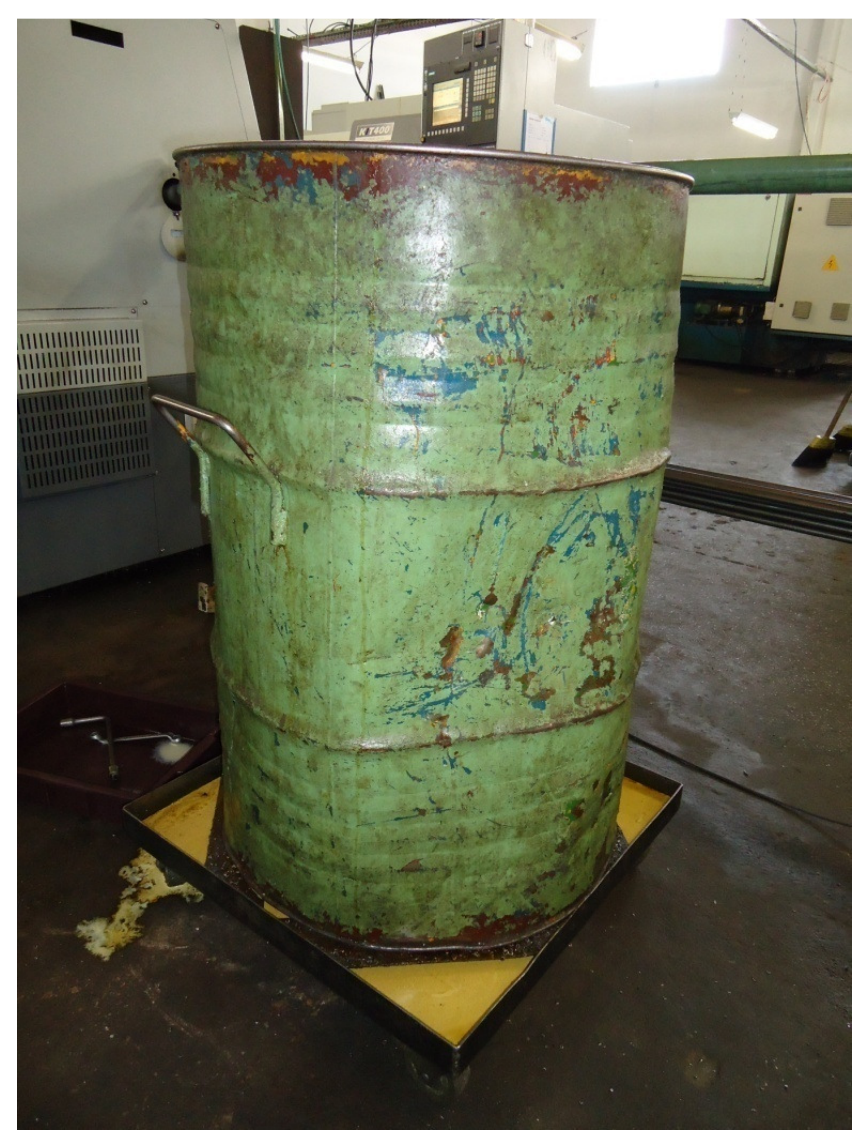

Foto 3 - Tambor metálico para acondicionamento do cavaco. 


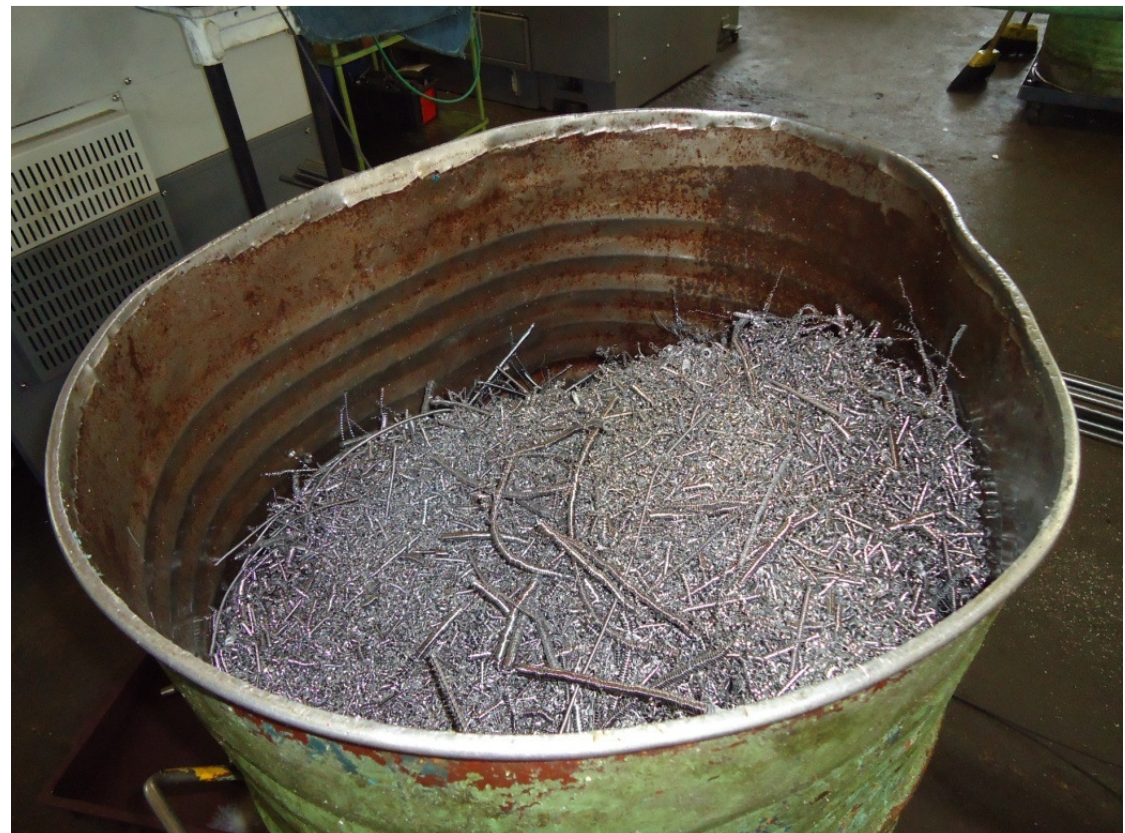

Foto 4 - Detalhe do cavaco acondicionado no tambor metálico.

Estes tambores possuem furos na parte inferior para que o fluído de corte perdido com o cavaco possa escoar e seja recolhido. Este fluído fica armazenado na estrutura suporte onde os tambores são colocados (Foto 5). Além disso, o suporte é dotado de rodas para facilitar o deslocamento dos tambores para a área externa do galpão da indústria quando a empresa de sucata que compra os cavacos vem retirálos.

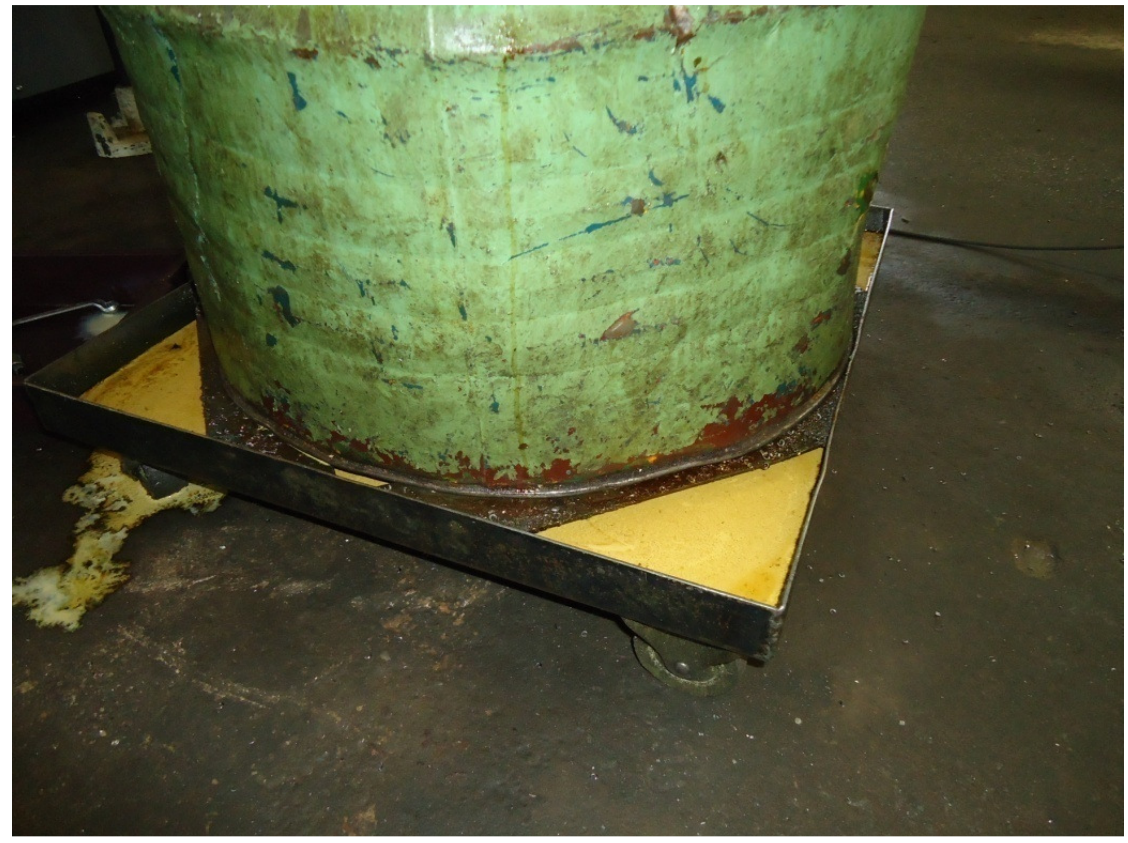

Foto 5 - Detalhe do suporte sob o tambor de cavaco onde é coletado o fluído de corte usado. 
O fluído de corte usado coletado nas bandejas é armazenado em tambor plástico onde o funcionário responsável pelos óleos improvisou um filtro para retirar as impurezas. Depois de filtrado o fluído é reaproveitado no processo.

As pontas de barra e refugo são acondicionadas em caixas plásticas conforme apresentado na Foto 6.

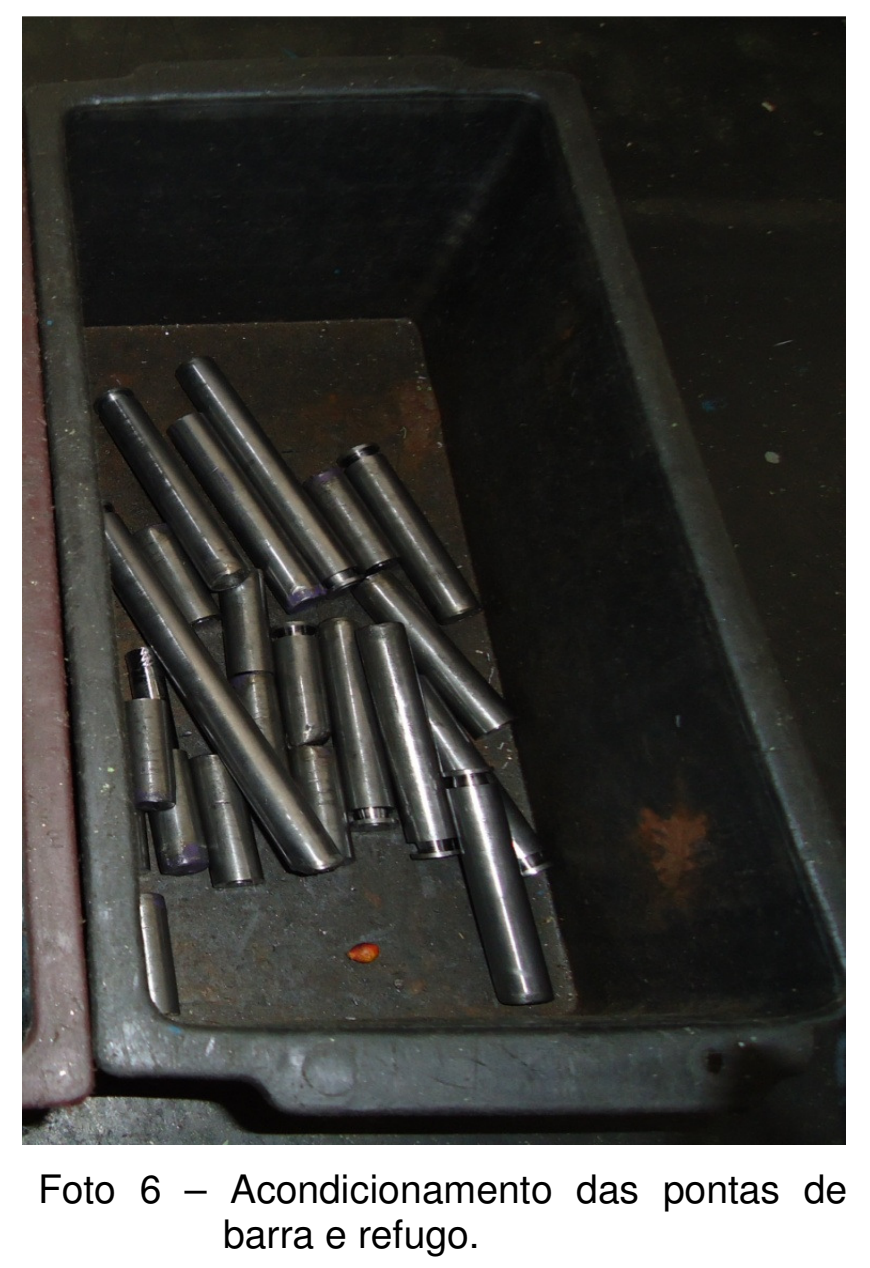

São nestas caixas também que a peça $A$ é acondicionada, tanto para encaminhamento a empresa especializada para revestimento galvânico, como para o comprador. Na Foto 7 tem-se a peça A pronta para expedição final.

O cavaco e os refugos das barras de aço são vendidos para sucateiros da região, que são responsáveis pela coleta e transporte destes resíduos. Quanto as ferramentas usadas estas são acondicionadas em caixa plástica (Foto 8) dentro de um armário na área interna da indústria para posterior venda ao próprio fornecedor. 


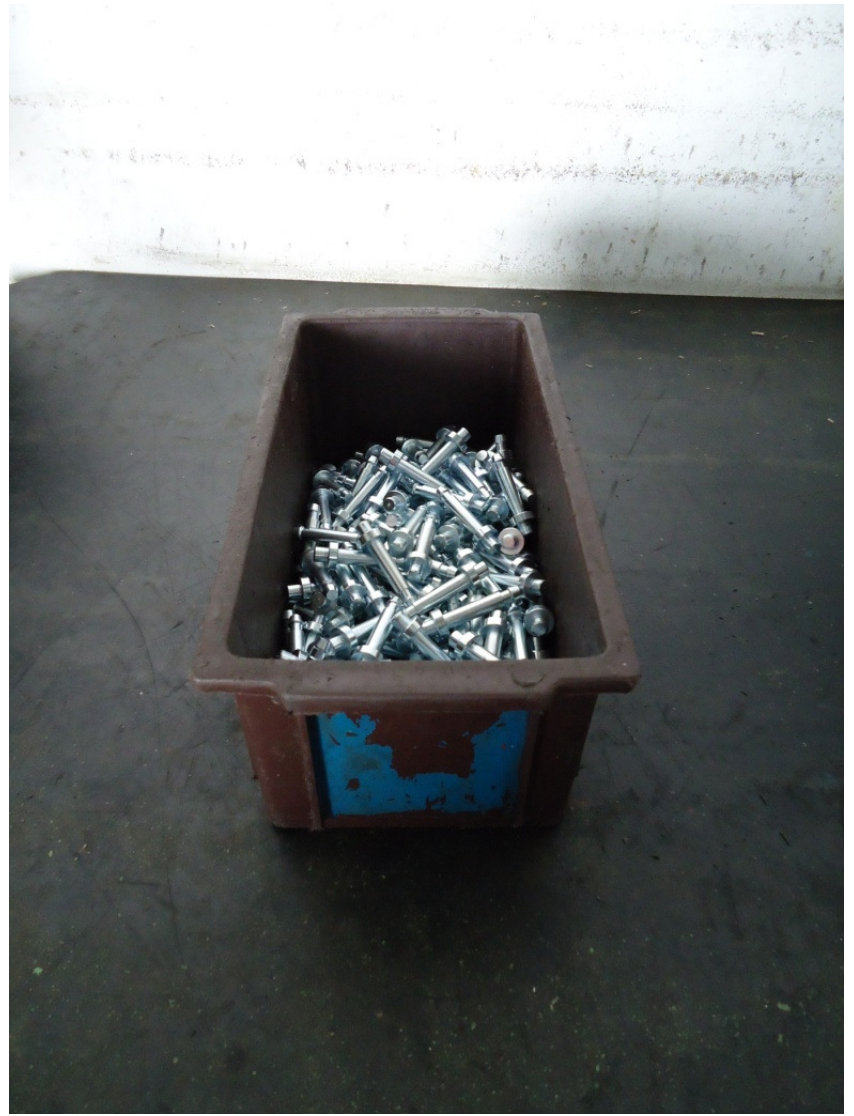

Foto 7 - Peça A pronta para expedição ao comprador.

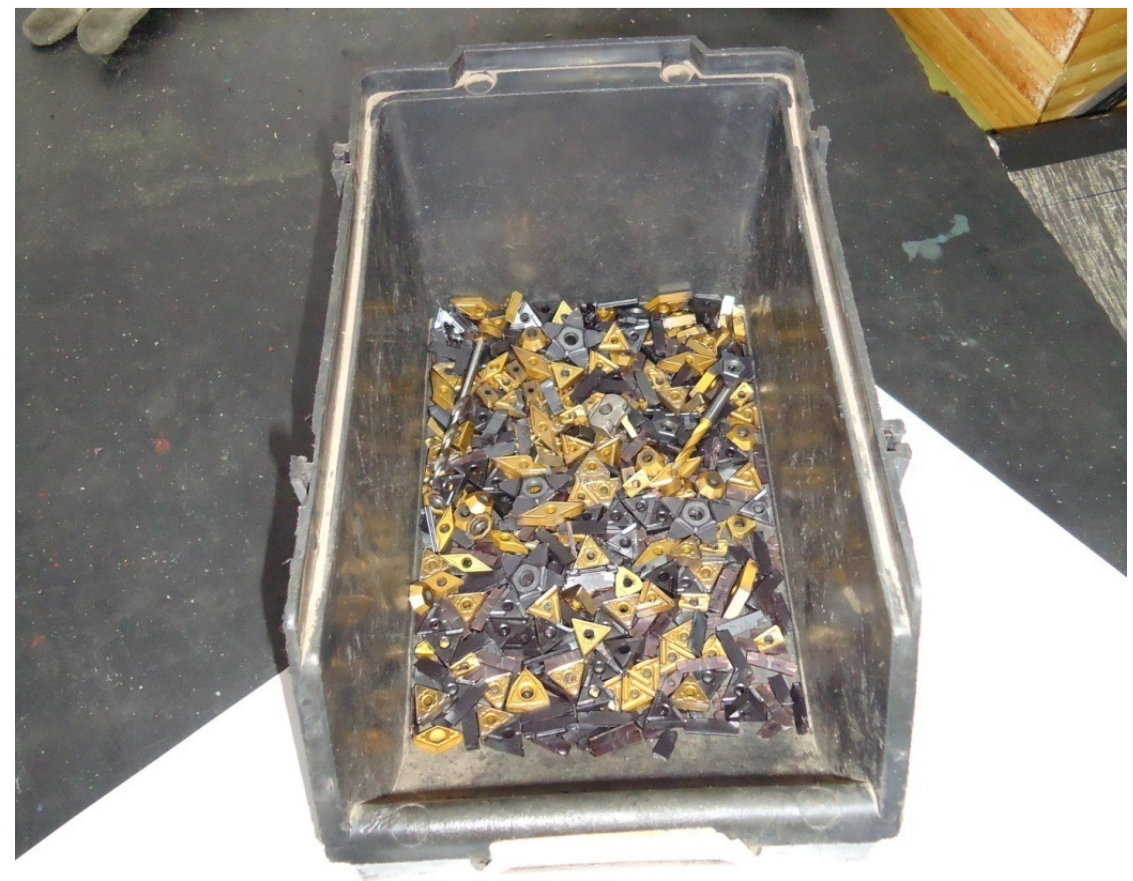

Foto 8 - Acondicionamento da ferramenta usada. 
Os óleos usados são acondicionados nos seus tambores de origem, que ficam armazenados em área aberta até recolhimento por empresa especializada para rerrefino (Foto 9).

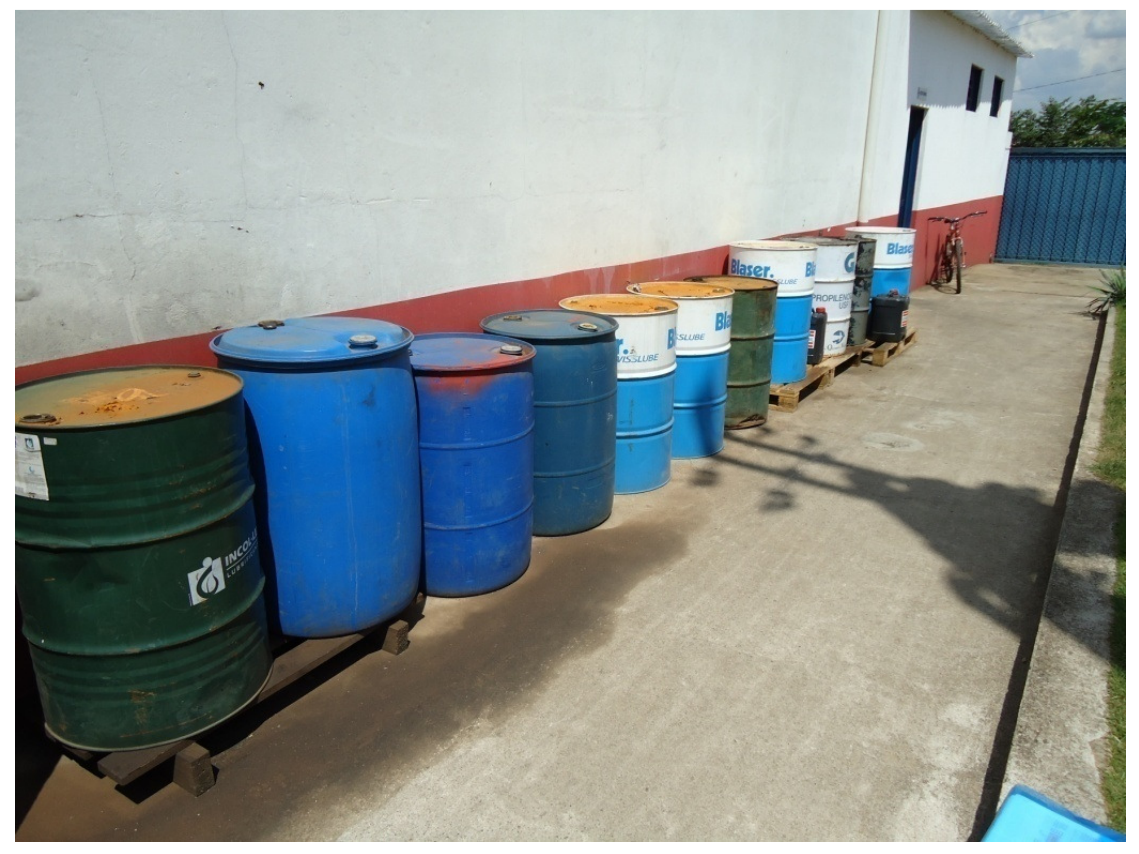

Foto 9 - Área de armazenamento dos óleos.

Os panos sujos com óleo são acondicionados em sacos de tecidos em área interna (Foto 10) da indústria até a retirada por empresa especializada que realiza a reposição (Foto 11) e reciclagem dos mesmos.

$O$ quadro a seguir apresenta um resumo da forma de manuseio dos resíduos gerados para a produção da peça $\mathrm{A}$. 


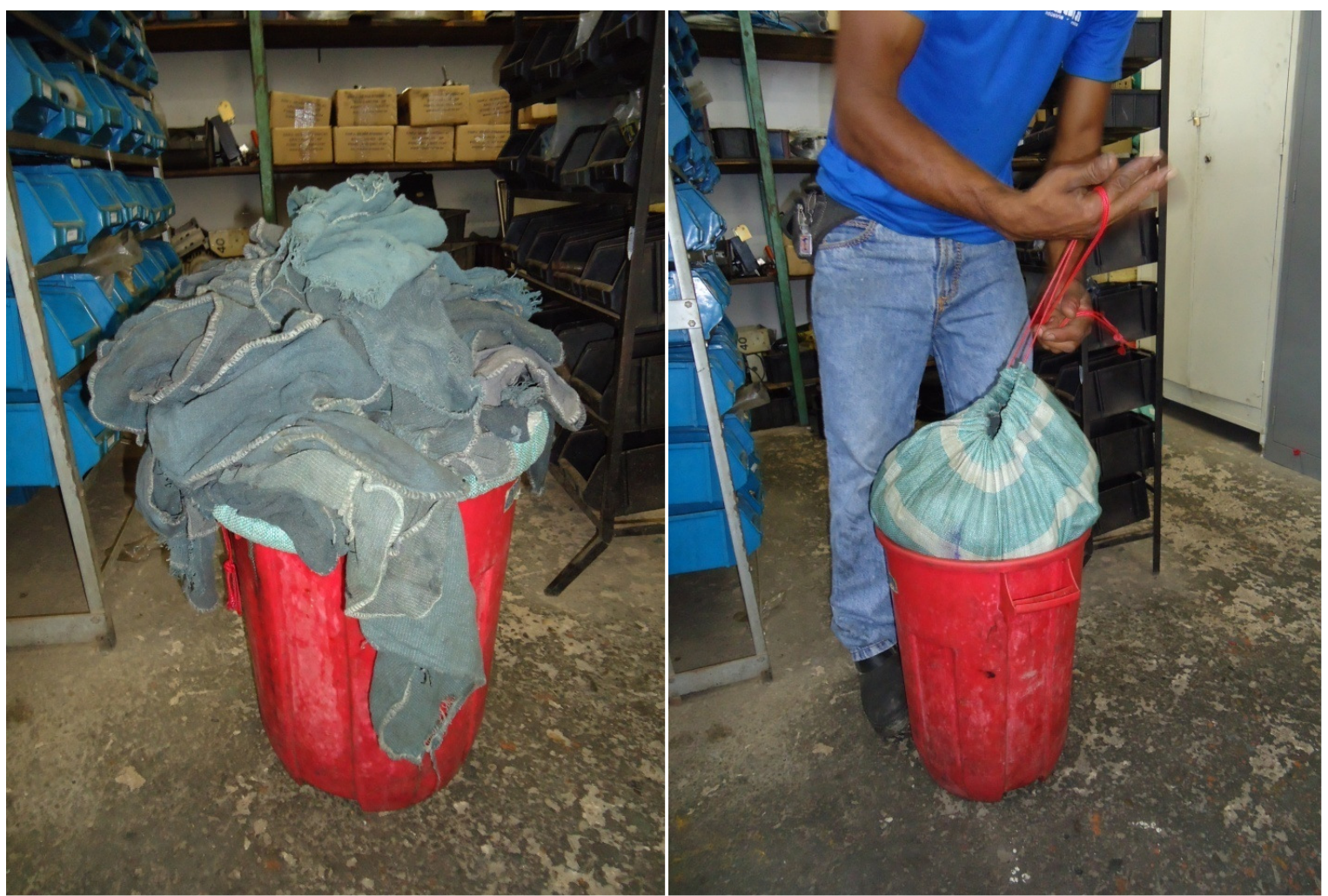

Foto 10 - Acondicionamento dos panos sujos com óleo.

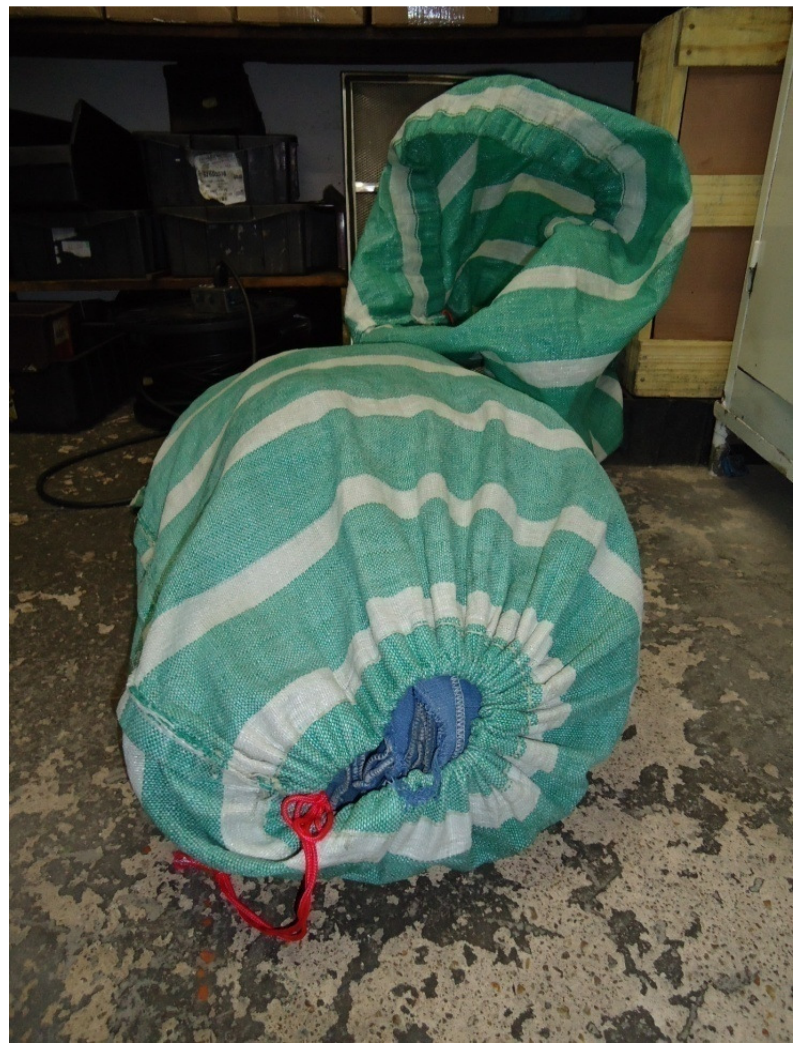

Foto 11 - Reposição de panos limpos pela empresa de reciclagem. 
Quadro 17 - Forma de manuseio e gerenciamento dos resíduos.

\begin{tabular}{|c|c|c|c|c|c|}
\hline Resíduo & Classe & Acondicionamento & Armazenamento & Transporte & Disposição final \\
\hline Ferramenta usada & II & Caixa plástica & $\begin{array}{c}\text { Dentro de armário na área interna da } \\
\text { indústria }\end{array}$ & Caminhão por terceiros & Venda para o fornecedor \\
\hline $\begin{array}{l}\text { Refugo de ponta de } \\
\text { barra }\end{array}$ & II & Caixa plástica & Área interna da indústria & Caminhão por terceiros & Venda para sucateiro \\
\hline Fluido de corte & 1 & Tambor de origem & Sob piso de concreto a céu aberto & Caminhão por terceiros & $\begin{array}{l}\text { Rerrefino por empresa } \\
\text { contratada }\end{array}$ \\
\hline $\begin{array}{l}\text { Pano contaminado } \\
\text { com óleo }\end{array}$ & I & $\begin{array}{l}\text { Bag de tecido dentro } \\
\text { de tambor plástico }\end{array}$ & Área interna da indústria & Caminhão por terceiros & $\begin{array}{l}\text { Reciclagem em empresa } \\
\text { especializada }\end{array}$ \\
\hline
\end{tabular}




\subsection{Proposição de melhorias no gerenciamento dos resíduos}

Neste item procura-se a partir do diagnóstico referente ao gerenciamento dos resíduos sólidos gerados na produção da peça $A$ propor-se melhorias nas práticas da empresa. As propostas foram fundamentadas na pesquisa bibliográfica realizada e nas normas referentes ao manuseio de resíduos. Além disso, são elencadas oportunidades de produção mais limpa para otimizar este gerenciamento.

\subsubsection{Plano de Gerenciamento de Resíduos Sólidos}

A existência de planejamento no gerenciamento dos resíduos numa indústria é importante para evitar acidentes com riscos a saúde humana e ao meio ambiente, além de auxiliar na preservação dos recursos naturais através do uso sustentável da matéria-prima, energia e produtos auxiliares.

Desta forma, o primeiro ponto observado na empresa pesquisada foi a necessidade da elaboração do Plano de Gerenciamento de Resíduos Sólidos (PGRS). Como a empresa já possui Certificação de Qualidade acredita-se que o processo de documentação, padronização e controle operacional dos resíduos gerados no processo produtivo não se configurem em barreira.

Além disso, quanto o aspecto legal foi publicada recentemente a Lei $\mathrm{n}$. 12.305/2010 referente a Política Nacional de Resíduos Sólidos (PNRS) que determina a necessidade da elaboração do PGRS e deixa claro que o gerador dos resíduos é responsável pelos danos que por ventura sejam causados pelo gerenciamento inadequado dos mesmos.

Por ser empresa de pequeno porte, pode desenvolver seu PGRS de forma integrada com outras empresas com as quais opera regularmente, desde que todas estejam localizadas dentro da mesma área de abrangência da autoridade ambiental, conforme estabelece o regulamento da PNRS (art. 61) - Decreto n. ${ }^{-}$7.404, de 23 de dezembro de 2010. 
Ademais, o PGRS deve ser parte integrante do processo de licenciamento ambiental, conforme determina o artigo 19 da Política Estadual de Resíduos Sólidos

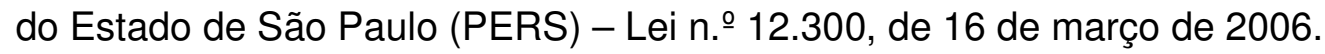

Tanto a Política Nacional como a Estadual de resíduos sólidos estabelecem o conteúdo mínimo para a elaboração do PGRS, conforme apresentado no quadro a seguir.

Quadro 18 - Conteúdo para elaboração do PGRS.

\begin{tabular}{|c|c|}
\hline art. 21) & \\
\hline $\begin{array}{l}\text { - descrição do empreendimento ou atividade; } \\
\text { - diagnóstico dos resíduos sólidos gerados, } \\
\text { contendo sua origem, volume e caracterização; } \\
\text { - explicitação dos responsáveis por cada etapa } \\
\text { do gerenciamento de resíduos sólidos; } \\
\text { - definição dos procedimentos operacionais } \\
\text { relativos às etapas do gerenciamento de } \\
\text { resíduos sólidos sob responsabilidade do } \\
\text { gerador; } \\
\text { - identificação das soluções consorciadas ou } \\
\text { compartilhadas com outros geradores; } \\
\text { - ações preventivas e corretivas a serem } \\
\text { executadas em situações de gerenciamento } \\
\text { incorreto ou acidentes; } \\
\text { - metas e procedimentos relacionados à } \\
\text { minimização da geração de resíduos sólidos e à } \\
\text { reutilização e reciclagem; } \\
\text { - ações relativas à responsabilidade } \\
\text { compartilhada pelo ciclo de vida dos produtos; } \\
\text { - medidas saneadoras dos passivos ambientais; } \\
\text { - periodicidade de sua revisão. }\end{array}$ & $\begin{array}{l}\text { - a origem, quantidade e caracterização dos } \\
\text { resíduos gerados, bem como os prazos máximos } \\
\text { para sua destinação; } \\
\text { - a estratégia geral do responsável pela geração, } \\
\text { reciclagem, tratamento e disposição dos } \\
\text { resíduos sólidos; } \\
\text { - as medidas que conduzam à otimização de } \\
\text { recursos, com vistas à implantação de soluções } \\
\text { conjuntas e ação integrada; } \\
\text { - a definição e a descrição de medidas e } \\
\text { soluções direcionadas: às praticas de prevenção } \\
\text { à poluição; à minimização dos resíduos gerados, } \\
\text { através da reutilização, reciclagem } \\
\text { recuperação; à compostagem; e ao tratamento } \\
\text { ambientalmente adequado; } \\
\text { - a forma de transporte, armazenamento e } \\
\text { disposição final; } \\
\text { - as ações preventivas e corretivas a serem } \\
\text { praticadas no caso de manuseio incorreto ou de } \\
\text { acidentes. }\end{array}$ \\
\hline
\end{tabular}

Nota: PNRS - Política Nacional de Resíduos Sólidos

PERS - Política Estadual de Resíduos Sólidos.

Fonte: Elaborado a partir da Lei n.ำ 12.305/2010 e Lei n.ำ12.300/2006.

A adoção de estratégias para prevenir a geração dos resíduos faz parte do Plano, como pode ser observado no quadro, tanto para a PNRS como para a PERS. Neste sentido o programa de produção mais limpa pode ser utilizado como metodologia para realizar o diagnóstico na empresa, identificar as oportunidades como também para auxiliar no estabelecimento de metas de redução.

O diagnóstico é importante para conhecer todos os resíduos gerados na empresa, em quais processos são gerados, sua quantidade e periculosidade. Em função destas características pode ser elaborado um fluxograma de gerenciamento dos resíduos (Figura 34) e padronizado o seu manuseio para o correto 
acondicionamento, armazenamento, transporte, destinação final e ações preventivas e corretivas em caso de acidentes.

As normas e os regulamentos legais existentes, referentes ao gerenciamento dos resíduos, devem ser conhecidos e seguidos. É importante também que seja previsto no Plano treinamento periódico para os funcionários. O item 4.1 desta pesquisa apresenta as informações básicas para o treinamento do pessoal envolvido no manuseio de resíduos.

O PGRS deve conter alguns documentos básicos para que as etapas de gerenciamento sejam padronizadas e obedeçam a procedimentos específicos (SANTOS, 2006; NAIME, 2005):

- Objetivos e Metas: os objetivos devem atender a conceitos gerais esperados, enquanto as metas apresentem números a serem alcançados e prazos. A organização deve estabelecer seus objetivos e metas de acordo com sua realidade, sua cultura, seus interesses, sua realidade operacional e sua inserção mercadológica. Além disso, recomenda-se que os mesmos sejam factíveis e viáveis, claros e mensuráveis, de forma que o seu incremento leve a uma minimização dos impactos significativos, controle dos efeitos e melhoria geral dos sistemas, atendendo a requisitos legais, normativos e das partes interessadas.

- Requisitos Legais e Outros: devem estar documentos no PGRS toda legislação pertinente, incluindo leis, normas, regulamentos, portarias e todo arcabouço jurídico existente, que deve ser atualizado constantemente. Atenção especial deve ser considerada em relação aos fatores condicionantes e restritivos das Licenças de Operação, emitidas pelos órgãos reguladores.

- Procedimentos Escritos: todas as atividades envolvidas no gerenciamento dos resíduos devem estar balizadas por procedimentos escritos. Estes procedimentos objetivam coibir situações nas quais sua ausência poderia levar a desvios das políticas, objetivos e alvos ambientais ou especificações legais e regulamentares pertinentes. Além disso, é importante a documentação e registro das ações de gerenciamento. Deve-se enfatizar que documentar ou registrar não significa burocratizar, mas sim criar uma memória ativa que auxilie na implementação das melhorias permanentes e possibilite um adequado gerenciamento. 


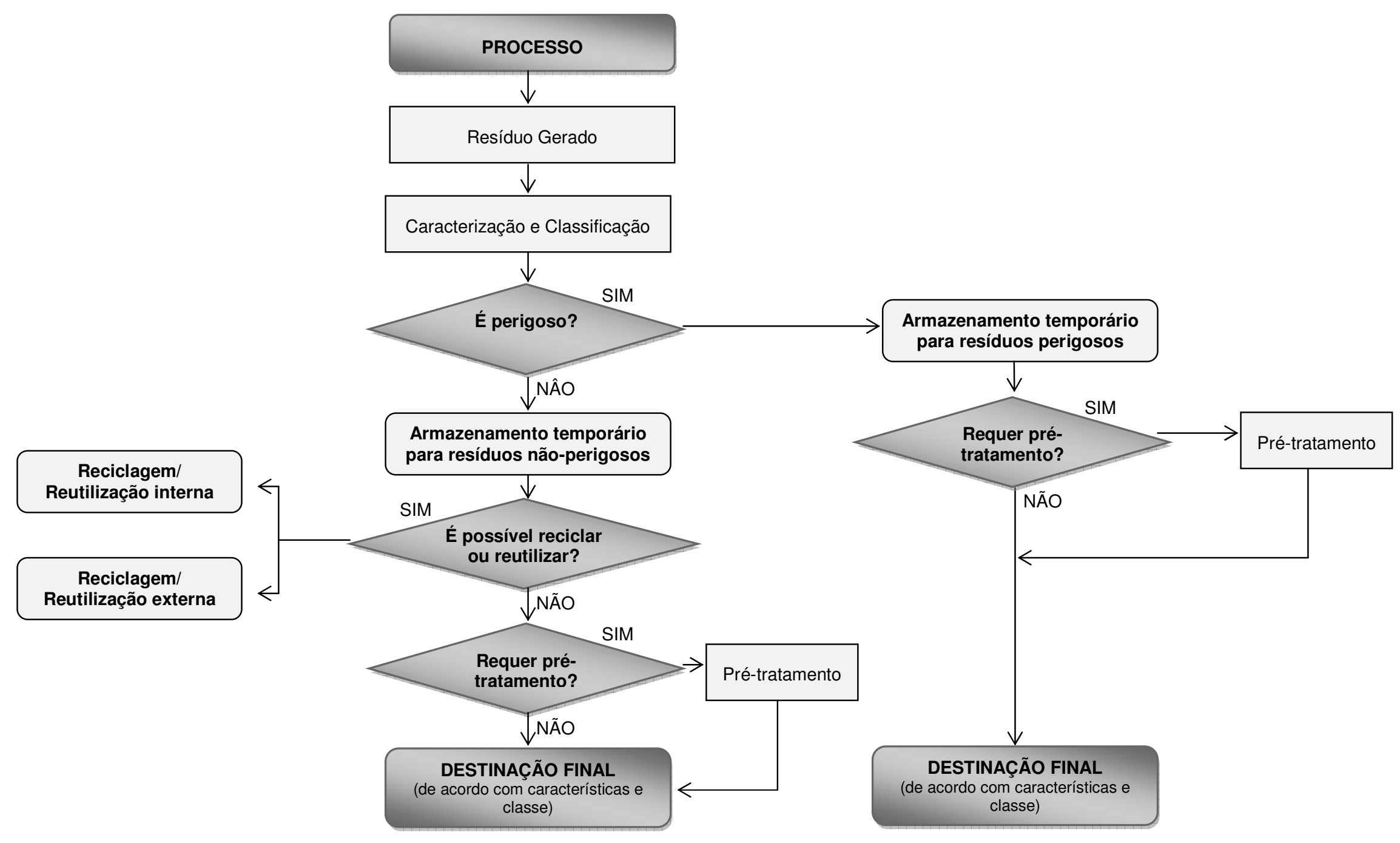

Figura 34 - Fluxograma de Gerenciamento de resíduos sólidos. Fonte: MAROUN, 2006, p.7. 
- Protocolos de Auditorias: para a realização das auditorias internas e dos terceiros que prestam serviço para a empresa em determinadas atividades constantes do PGRS, devem ser desenvolvidos protocolos específicos, documentados. As auditorias são processos de verificação sistemáticas e documentadas para, objetivamente, obter e avaliar evidências que determinam se aspectos ambientais específicos das atividades, eventos, condições e sistemas de gerenciamento, apresentam conformidade.

- Indicadores: os indicadores para acompanhamento do desempenho do PGRS também deverão estar devidamente documentados, possibilitando a comparação dos mesmos em diferentes períodos. Exemplos de indicadores foram apresentados no item 5.6 desta pesquisa. Além disso, apresentam-se na Tabela 3 indicadores que foram obtidos a partir do levantamento dos dados na Indústria X. Através dos indicadores será possível avaliar se os objetivos e metas estão sendo alcançados, além do desempenho ambiental do processo industrial. Deve-se notar também que não faz sentido uma organização investir recursos financeiros e muitos recursos humanos que também têm seu custo transferido para a conta de capital, sem que tenha a preocupação em obter resultados satisfatórios, tanto sob a dimensão institucional, quanto sob o próprio enfoque gerencial, e com resultados ambientais percebidos e incontestáveis externamente.

Tabela 3 - Indicadores do gerenciamento dos resíduos sólidos na Indústria $X$ referente ao processamento da peça $A$.

\begin{tabular}{|c|c|c|c|c|}
\hline & Indicador & Quantidade & Unidade & $\mathrm{Kg} / 1000$ peças \\
\hline \multirow{4}{*}{ 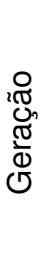 } & Total de Resíduos gerados & 72.477 & $\mathrm{Kg} / \mathrm{ano}$ & 69,76 \\
\hline & Em termos de cavacos & 67,7 & $\%$ & 47,25 \\
\hline & Em termos de ponta de barra & 5,0 & $\%$ & 3,51 \\
\hline & Em termos de fluído de corte & 0,6 & $\%$ & 0,40 \\
\hline \multirow{2}{*}{$\begin{array}{l}\mathbb{D} \\
\mathbb{N} \\
\mathbb{O} \\
U\end{array}$} & Resíduos Classe I & 93,7 & $\%$ & 66,24 \\
\hline & Resíduos Classe II & 6,3 & $\%$ & 3,51 \\
\hline \multirow{3}{*}{ 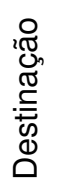 } & Resíduos oleosos vendidos para rerrefino & 46,0 & $\%$ & 0,30 \\
\hline & Resíduo oleoso vendido junto com o cavaco & 37,0 & $\%$ & 0,23 \\
\hline & Resíduo oleoso reciclado internamente & 17,0 & $\%$ & 0,11 \\
\hline
\end{tabular}


- Fichas de Resíduos: é interessante que cada resíduo gerado tenha uma ficha própria, na qual estejam descritas todas as características do resíduo e suas formas de gestão. Uma proposição de ficha de resíduos que foi elaborada para os fluídos de corte esgotados é apresentada no Quadro a seguir.

Quadro 19 - Proposição de ficha de resíduo para o fluído de corte esgotado.

\section{CARACTERIZAÇÃO}

Fluído de corte de origem vegetal esgotado proveniente das operações de usinagem no torno CNC.

\section{MEDIDAS DE SEGURANÇA}

Recomenda-se o uso de luvas impermeáveis e óculos de proteção.

Em caso de contato com a pele lavar com sabão e água fresca. Roupas contaminadas devem ser removidas e lavadas. Em caso de contato com os olhos lavar com água em abundância durante 15 minutos. Consultar médico se necessário.

\section{OPÇÕES DE PRODUÇÃO MAIS LIMPA}

Manter hábitos de higiene.

Realizar manutenção preventiva.

Não entrar em contato com o fluído nem jogar materiais estranhos no tanque do torno.

Observar a direção e a concentração do jato do fluido para que sua função seja mais eficiente.

Preparar a solução de fluído de corte no recipiente adequado observando a concentração recomendada.

Observar a qualidade e a quantidade de água utilizada para a diluição do concentrado.

Monitorar a concentração, pH e a presença de óleos estranhos.

\section{MÉTODOS DE GERENCIAMENTO}

Depois que as medidas de produção mais limpa tiverem sido adotadas, a seguinte seqüência de gerenciamento do resíduo deve ser utilizada:

\section{Armazenamento temporário}

Em contêiner para resíduos perigosos em área apropriada (conforme NBR 12.235/92).

2. Transporte

Deve ser realizado por empresa autorizada pelo órgão ambiental, estar acompanhado do CADRI e atender os requisitos da NBR 13.221/2000.

\section{Destinação final}

Rerrefino (apenas em empresas autorizadas pelo órgão ambiental competente) ou devolução ao fabricante.

Deve-se notar que da mesma forma como o programa de Produção mais Limpa, o PGRS deve contar com um monitoramento para avaliação do desempenho da empresa através dos indicadores criados durante sua implantação. Estes indicadores deverão ser reavaliados ao longo do seu funcionamento, de forma a espelhar da melhor maneira possível a eficácia dos processos conduzidos para o gerenciamento dos resíduos. 
O PGRS deverá ser analisado e revisado periodicamente, quando poderão ser propostos novos objetivos e metas a serem alcançados pela empresa para melhoria contínua do processo.

\subsubsection{Manuseio dos resíduos}

Foi identificada a necessidade de melhoria das práticas no manuseio dos resíduos nas seguintes etapas: acondicionamento e armazenamento dos resíduos oleosos. Importante também para o manuseio dos resíduos, após a elaboração do PGRS e dos procedimentos de gerenciamento, que os funcionários passem por treinamentos quanto a melhor forma de procederem nas situações rotineiras e em caso de acidentes.

Quanto ao acondicionamento dos óleos usados, notou-se que alguns tambores estavam com marcas de corrosão e amassados. Apesar de não ter sido notado vazamento destes resíduos é importante que a empresa designe um funcionário para verificar a situação dos recipientes de acondicionamento para prevenir possíveis rompimentos e vazamentos, e quando necessário realizar a substituição dos mesmos. Pode estar previsto no próprio PGRS o responsável pelas verificações e a periodicidade com que estas devem ser realizadas.

Na visita a empresa notou-se que o armazenamento dos resíduos oleosos é realizado em área aberta sob piso de concreto. Tendo em vista a característica destes resíduos e para prevenir acidentes a área de armazenamento deveria contar com as seguintes melhorias para atender a NBR 12.235/92:

- Ser dotada de coberta e em local ventilado.

- Possuir sistema de drenagem e captação de líquidos contaminados, para posterior tratamento.

- Os recipientes devem estar rotulados para rápida identificação e apresentar boa condição de uso (sem ferrugem e defeito estrutural).

- Os recipientes devem ser mantidos fechados e quando manuseados deve ser utilizado EPI's (Equipamentos de Proteção Individual).

- Os contêineres e tambores devem ser dispostos de forma a possibilitar inspeção visual. 
O transporte e destinação final dos resíduos são realizados por terceiros. É importante que a indústria trabalhe apenas com empresas licenciadas pelos órgãos ambientais e mantenha registro de todos os resíduos vendidos.

Verificou-se que duas das empresas que realizam estas etapas são certificadas. No caso dos óleos são retirados por uma empresa estabelecida no estado de São Paulo que possui certificação (ISO 9.001 e ISO 14.001) e que realiza o rerrefino dos mesmos. A empresa que recolhe os panos contaminados com óleo também possui certificação. Esta empresa, estabelecida no estado de São Paulo, fornece as toalhas industriais recicláveis (pano de limpeza) e após seu uso recolhem-nas.

\subsubsection{Oportunidades de produção mais limpa}

As oportunidades de produção mais limpa foram analisadas por resíduo, partindo daquele que é gerado em maior quantidade e priorizando ações de redução na fonte.

Verificou-se a partir do levantamento da quantidade de aço utilizado na empresa para produção da peça $A$ e da quantidade de resíduos de aço, que apenas $33 \%$ da matéria-prima em termos de barras de aço que entra no processo convertese no produto (Figura 35). 


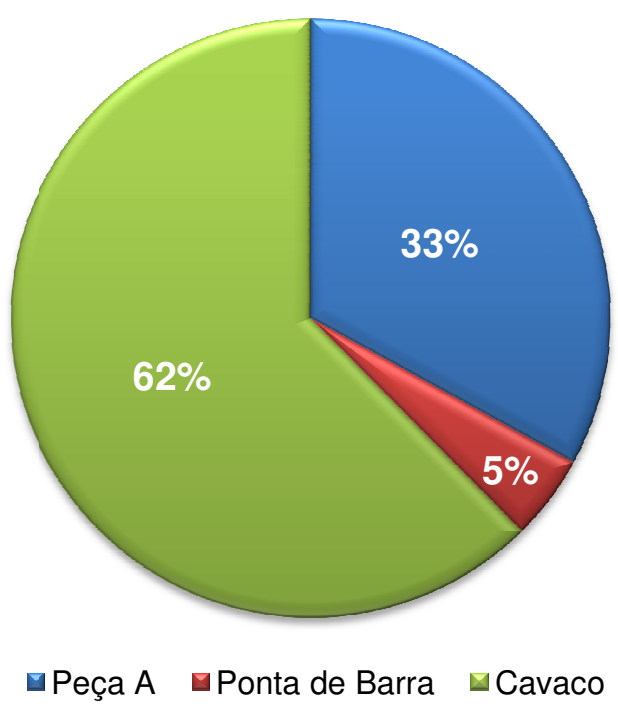

Figura 35 - Distribuição da matéria prima (barras de aço).

A maior parte das barras de aço utilizadas para a produção da peça $A, 62 \%$, sai do processo na forma de cavacos. A Indústria $X$ já utiliza barras de aço no diâmetro adequado tendo em vista as dimensões do produto final. Para reduzir essa quantidade seria necessário alterar o design da peça $A$, o que está fora do alcance da empresa tendo em vista que o projeto da mesma é fornecido pelo cliente.

A ponta de barra apresenta variação quanto sua quantidade de geração, tendo em vista a variação dos comprimentos das barras de aço fornecidas. Uma variação de um centímetro a mais no seu comprimento em todas as barras processadas implica na produção de $01 \mathrm{Kg}$ de ponta de barra por dia, o que em um ano representa $262 \mathrm{Kg}$. Uma maneira de diminuir a quantidade de resíduos de ponta de barra é exigir do fornecedor maior padronização dos comprimentos das barras.

O fluído de corte utilizado na usinagem da peça $A$ é a base de óleo de éster vegetal (canola). Este óleo é ambientalmente mais adequado por ser menos poluente, apresentar maior facilidade de degradação podendo ser tratado por meio biológico ou químico, provir de fonte renovável e implicar em menor risco a saúde do operador. Em contrapartida este óleo apresenta elevados custos em comparação com os demais.

Constatou-se que o fluído de corte recebe manutenção periódica com adição de aditivos, mas existem momentos em que suas propriedades diminuem (fenômeno conhecido como stress mecânico) como também, este se torna contaminado ao ponto de haver a necessidade do seu descarte. Segundo a Bardahl (2010), dentre 
os problemas mais comuns e suas causas devido a contaminação dos fluídos de corte estão:

- Mau cheiro: presença de bactéria, excesso de óleo de barramento no fluido de corte (as máquinas têm um sistema centralizado para lubrificação das guias e barramentos. Os fabricantes regulam a máquina para serem bem lubrificadas, porém o excesso de óleo no fluido de corte - pois ele é arrastado para o reservatório - oferece os alimentos adequados para as bactérias).

- Corrosão nas peças: presença de bactéria, ácido úrico do operador, concentração baixa do fluido de corte;

- Corrosão na máquina: presença de bactéria e concentração baixa do fluido de corte;

- Mudança de coloração no fluido de corte: concentração inadequada, geralmente mais baixa ou somente com água.

Foi informado que no máximo a empresa realiza duas limpezas nos tanques de fluído de corte, o que totaliza 64 L/ano de fluído descartado. Outro ponto de perdas de fluído de corte é seu arraste com o cavaco. A figura a seguir apresenta a porcentagem de fluído de corte perdido tanto com o arraste pelo cavaco como pelas limpezas.

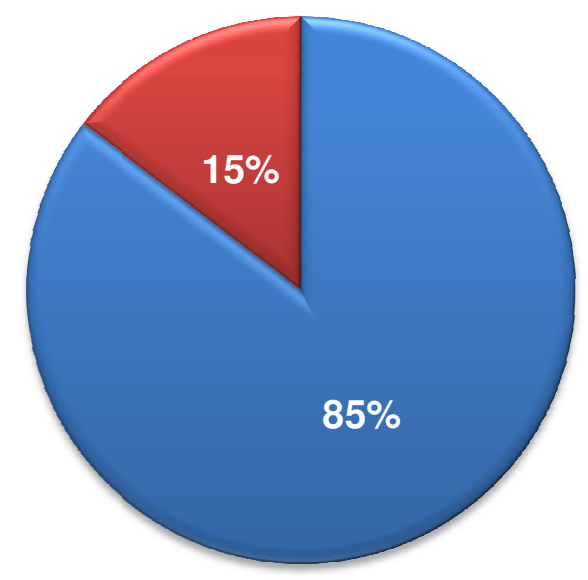

- Fluído de corte arrastado com o cavaco

$\square$ Fluído de corte descartado nas limpezas

Figura 36 - Distribuição do fluído de corte perdido no processo de usinagem da peça $A$. 
Do fluído de corte arrastado com o cavaco, que representa $85 \%$ do que é perdido no processo, parte é recuperado no tambor de armazenamento de cavaco, como foi apresentado no item 8.2, referente ao gerenciamento dos resíduos na empresa. Estima-se que de 0,4 a 0,5 L de fluído corte por dia sejam recuperados e retornam ao processo, sem contar o volume de água que também se encontra presente. No período de um ano esta quantidade representa de 104 a $130 \mathrm{~L}$ do fluído.

Notou-se que a empresa tem esta preocupação de coletar o fluído dos tambores de cavaco tendo em vista o alto custo para sua aquisição. Mesmo assim, estima-se que ainda sejam perdidos em média $257 \mathrm{~L}$ de fluído de corte por ano, o que representa uma perda de quase $R \$ 10.000,00 / a n o$.

Para reduzir as perdas com o fluído de corte nos processos algumas medidas podem ser adotadas:

Quadro 20 - Medidas para evitar a contaminação e descarte do fluído de corte.

\begin{tabular}{|c|c|}
\hline PARÂMETRO & MEDIDAS \\
\hline Fornecedores & $\begin{array}{l}\text { - Evitar fornecedores que não ofereçam garantias de procedência, } \\
\text { assistência e composição dos fluidos de corte; } \\
\text { - Evitar fornecedores que não ofereçam suporte de informações } \\
\text { ao programa de manejo ambiental da empresa. }\end{array}$ \\
\hline Hábitos de Higiene & $\begin{array}{l}\text { - Desenvolver procedimentos que promovam hábitos de higiene } \\
\text { no trabalho; } \\
\text { - Treinar corretamente os operadores para evitar qualquer hábito } \\
\text { que provoque contaminação, como por exemplo: evitar o uso de } \\
\text { panos que desfiam para limpeza das peças, não jogar bituca ou } \\
\text { cinzas de cigarro no equipamento, não lavar as mãos no fluído de } \\
\text { corte, entre outros. }\end{array}$ \\
\hline Procedência da peça & $\begin{array}{l}\text { - Evitar usinar peças que tenham contaminantes, tais como: } \\
\text { graxa, ferrugem e resíduo de óleo protetivo. Caso necessário, } \\
\text { realizar limpeza antes de usinar; } \\
\text { - Verificar se houve manuseio incorreto da peça. O fluido de corte } \\
\text { de outro torno pode contaminar a máquina. }\end{array}$ \\
\hline Procedimentos de usinagem & $\begin{array}{l}\text { - Estabelecer procedimentos aos equipamentos para que o } \\
\text { conjunto esteja adequado aos requisitos da operação; } \\
\text { - Observar a direção e a concentração do jato do fluido para que } \\
\text { sua função seja mais eficiente. }\end{array}$ \\
\hline
\end{tabular}

Continua 
Conclusão

\begin{tabular}{|c|c|}
\hline PARÂMETRO & MEDIDAS \\
\hline Preparo da solução & $\begin{array}{l}\text { - Evitar preparar a mistura na máquina operatriz. Fazer a solução } \\
\text { sempre em um recipiente limpo à parte, que pode ser um balde de } \\
20 \text { litros ou tambor de } 200 \text { litros; } \\
\text { - Calcular a quantidade de óleo a ser diluída na água. Nunca } \\
\text { acrescentar óleo puro na máquina. Se precisar corrigir a mistura, } \\
\text { preparar uma nova solução; } \\
\text { - Preparar num reservatório à parte as possíveis reposições, } \\
\text { evitando assim erros na concentração da solução; } \\
\text { - Misturar sempre a água sobre o concentrado, evitando, assim, a } \\
\text { mistura invertida; } \\
\text { - Agitar corretamente a mistura no momento da diluição do } \\
\text { concentrado; } \\
\text { - Planejar operações que controlem a concentração dos fluidos, } \\
\text { mantendo-as dentro das porcentagens recomendadas pelo } \\
\text { fabricante; } \\
\text { - Utilizar um refratômetro portátil para verificar a concentração do } \\
\text { fluído. }\end{array}$ \\
\hline $\begin{array}{l}\text { Óleos contaminantes e fugas do } \\
\text { sistema hidráulico }\end{array}$ & $\begin{array}{l}\text { - Implantar plano de manutenção do sistema; } \\
\text { - Realizar manutenção preventiva e emprego de juntas ótimas que } \\
\text { reduzam fugas; } \\
\text { - Empregar o mesmo óleo base para formulação de fluidos de } \\
\text { usinagem, sistemas hidráulicos e engraxe; } \\
\text { - Instalar decantadores ou centrífugas para separação dos óleos } \\
\text { contaminantes. }\end{array}$ \\
\hline Controle da qualidade & $\begin{array}{l}\text { - Monitorar a concentração de biocidas e o pH do fluido em } \\
\text { operação; } \\
\text { - Seguir as recomendações do fabricante; } \\
\text { - Observar a qualidade e a quantidade de água utilizada para a } \\
\text { diluição do concentrado; } \\
\text { - Monitorar a presença de óleos estranhos no fluído para evitar } \\
\text { aumento na sua velocidade de degradação. }\end{array}$ \\
\hline
\end{tabular}

Fonte: Elaborado a partir de OLIVEIRA \& ALVES, 2007; BARDAHL, 2010; CNTL, 2006.

No caso das perdas pelo arraste com o cavaco a empresa pode realizar a recuperação e reciclagem do fluído de corte para seu retorno ao processo, aumentando sua vida útil e reduzindo a geração de resíduos. Segundo Oliveira \& Alves (2007), para a reciclagem do fluido de corte pode ser empregado um sistema (Figura 37) com tratamento intermitente, capaz de remover contaminantes (óleo, sujeira, bactéria) e reajustar com a frequência necessária a concentração do fluido antes de seu retorno à máquina individual. 


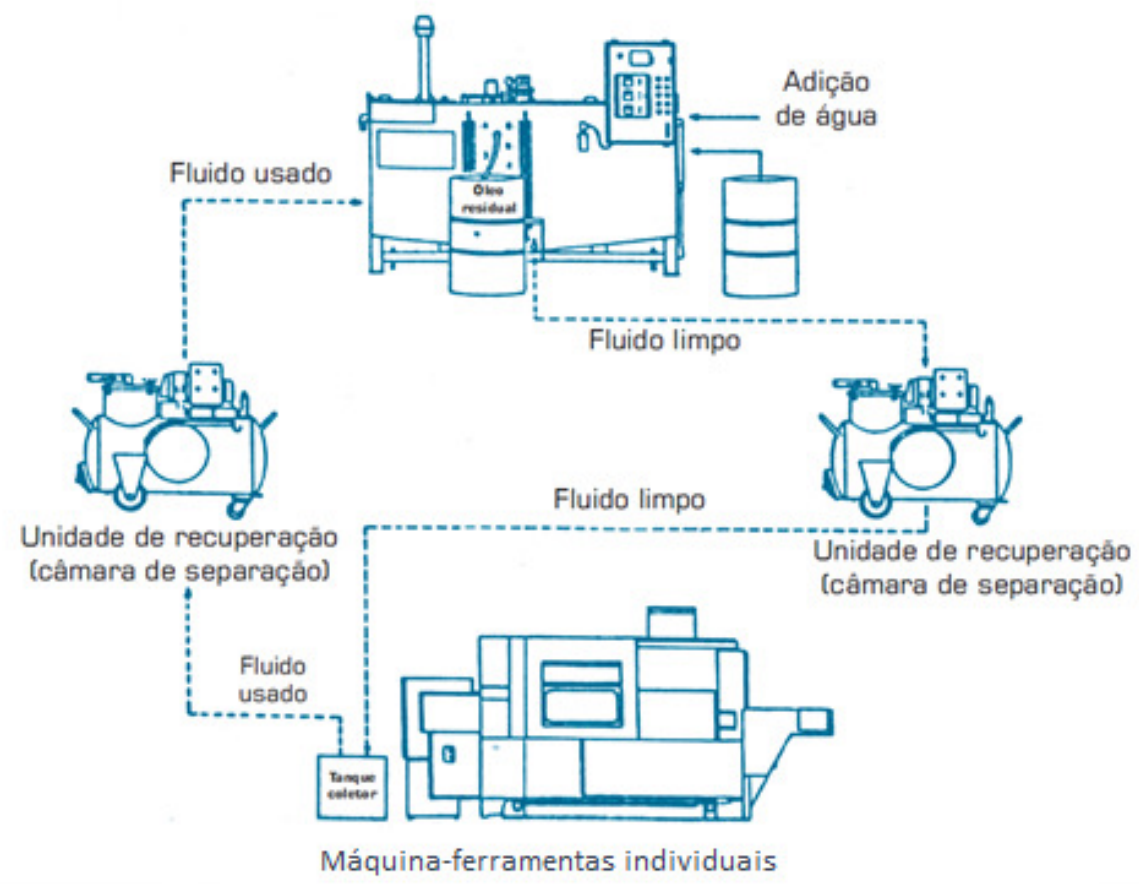

Figura 37 - Equipamentos de gerenciamento de fluidos utilizados nas operações de transformação de metais.

Fonte: OLIVEIRA \& ALVES, 2007, p. 136.

Podem ser empregados diferentes métodos para a separação do cavaco e do fluído de corte. O quadro a seguir apresenta estes métodos suas características, indicações e restrições. 


\section{Quadro 21 - Métodos para separação do cavaco e fluído de corte nos processos de usinagem.}

\begin{tabular}{|c|c|c|}
\hline Método & Característica/ Indicação & Restrições \\
\hline Decantação & $\begin{array}{l}\text { A decantação como no caso do tratamento de águas é um processo de } \\
\text { separação por gravidade. Usualmente existem dispositivos auxiliares como } \\
\text { barras raspadoras, planos inclinados, chicanas de separação, etc., com o } \\
\text { objetivo de melhorar a performance da operação. } \\
\text { O sistema é indicado para fluidos que se separem rapidamente das } \\
\text { impurezas. É o caso dos fluidos sintéticos para retificação. É muito } \\
\text { indicada para fluidos usados na retificação de ferro fundido e vidro. }\end{array}$ & $\begin{array}{l}\text { No caso do uso do tanque separador, a queda livre } \\
\text { do fluido torna desaconselhável o uso de fluidos que } \\
\text { tendem a formar espuma. Portanto, cuidados } \\
\text { especiais devem ser tomados no uso do método para } \\
\text { fluidos semi-sintéticos e emulsões. }\end{array}$ \\
\hline Filtro de gravidade & $\begin{array}{l}\text { É um sistema de tela rígida, tipo peneira, em geral recoberta por filtro. No } \\
\text { centro da tela existe uma depressão onde se deposita o fluido. A } \\
\text { passagem do fluido através do filtro ocorre por gravidade, sendo o fluido } \\
\text { coletado num tanque inferior. A velocidade de filtração decai a medida que } \\
\text { as impurezas se acumulam no filtro. Usualmente um sensor ativado pelo } \\
\text { nível de fluido acumulado na depressão, aciona um dispositivo para } \\
\text { renovação do meio filtrante (papel ou tecido, descartável), em geral por } \\
\text { enrolamento. }\end{array}$ & $\begin{array}{l}\text { O espaço ocupado pelo equipamento é grande em } \\
\text { comparação com outros tipos de filtragem, apesar do } \\
\text { pequeno investimento inicial. }\end{array}$ \\
\hline Filtro a vácuo & $\begin{array}{l}\text { São similares aos sistemas de gravidade, mas aceleram a passagem do } \\
\text { fluido pelos meios filtrantes (papel, tecido ou tela metálica, permanente ou } \\
\text { descartável) através de sucção. O vácuo é produzido num compartimento } \\
\text { selado, abaixo do meio filtrante. Possui em geral um sistema de esteira } \\
\text { com raspadores para remoção dos cavacos e limpeza do meio filtrante. A } \\
\text { esteira é acionada por um sensor de vácuo que é ativado quando aumenta } \\
\text { o vácuo na câmara inferior, pelo efeito de acúmulo de cavacos que } \\
\text { bloqueiam o fluxo de fluido. }\end{array}$ & $\begin{array}{l}\text { As partículas sólidas podem formar borra quase } \\
\text { impermeável (caso da retificação do ferro fundido ou } \\
\text { vidro) tornando o sistema caro e ineficiente. }\end{array}$ \\
\hline $\begin{array}{l}\text { Separadores de } \\
\text { ciclone }\end{array}$ & $\begin{array}{l}\text { Usa a centrifugação do fluido sujo dentro de um reservatório cônico. Uma } \\
\text { bomba produz a pressão necessária para gerar a ação de centrifugação. A } \\
\text { centrifugação separa os contaminantes sólidos que escorregam pela } \\
\text { parede, descendo para um reservatório. } \\
\text { Mais indicados para separar pequenas quantidades de contaminantes } \\
\text { sólidos, portanto são utilizados em combinação com tanques de } \\
\text { decantação. }\end{array}$ & $\begin{array}{l}\text { Em óleos de baixa viscosidade (para brunimento), a } \\
\text { água presente separa-se do óleo junto com os } \\
\text { cavacos. Contaminantes imiscíveis mais leves que o } \\
\text { fluido vão para o centro do vórtice, promovendo uma } \\
\text { mistura ainda maior com o fluido, prejudicando a } \\
\text { limpeza. O uso é limitado para fluidos com } \\
\text { viscosidade menor que } 20 \mathrm{cSt} \text { a } 40^{\circ} \mathrm{C}^{35} \text {. }\end{array}$ \\
\hline
\end{tabular}

\section{Continua}

${ }^{35}$ Viscosidade é normalmente expressa em termos de quanto tempo uma quantidade padrão do fluido a uma certa temperatura leva para fluir através de um orifício padrão. Quanto maior o valor, mais viscoso o fluido. Como a viscosidade varia inversamente à temperatura, o seu valor não tem significado algum a não ser que seja acompanhado pela temperatura na qual ela é determinada. Com óleos do petróleo, a viscosidade é normalmente informada em centistokes (cSt), medida a $40^{\circ} \mathrm{C}$ ou $100^{\circ} \mathrm{C}$ (Método D445 - Viscosidade Cinemática da American Society for Testing and Materials ASTM). 


\section{Conclusão}

\begin{tabular}{|c|c|c|}
\hline Método & Característica/ Indicação & Restrições \\
\hline Centrífugas & $\begin{array}{l}\text { São máquinas de centrifugação convencionais. Separam contaminantes } \\
\text { mais leves ou mais pesados que o fluido pelo princípio da força centrífuga. } \\
\text { Podem operar em diferentes velocidades, dependendo dos objetivos da } \\
\text { separação. São equipadas com cestos, onde ficam retidas as impurezas. A } \\
\text { maioria das centrífugas é auto-limpante, ou seja, o antigo problema de } \\
\text { limpeza dos cestos foi eliminado. } \\
\text { Para fluido integral, a centrifugação separa água e contaminantes finos. } \\
\text { Centrífugas de alta velocidade podem separar óleo contaminante de } \\
\text { emulsões. }\end{array}$ & $\begin{array}{l}\text { A velocidade de centrifugação deve ser controlada } \\
\text { quando se centrifugam emulsões grossas, para que o } \\
\text { óleo solúvel não seja separado da água pelo excesso } \\
\text { de velocidade. }\end{array}$ \\
\hline $\begin{array}{l}\text { Separadores por } \\
\text { flotação }\end{array}$ & $\begin{array}{l}\text { Promovem a separação através da formação de uma nata flutuante que } \\
\text { agrega as impurezas finas do fluido. Existe um tanque de decantação onde } \\
\text { inicialmente se depositam as partículas maiores. O fluido então é } \\
\text { bombeado para um tanque superior onde é aerado através de uma hélice. } \\
\text { As bolhas de ar formadas aderem às partículas finas formando uma nata- } \\
\text { espuma que passa a flutuar, sendo então escumada. } \\
\text { Indicados para fluidos de corte aquosos, do tipo leitoso. As partículas } \\
\text { devem estar umectadas para que aconteça uma boa flotação. }\end{array}$ & $\begin{array}{l}\text { A espuma junto com as impurezas deve ser capaz de } \\
\text { carregar as partículas finas. Se houver muita espuma } \\
\text { pode ocorrer transbordamento. Se houver pouca } \\
\text { espuma a flotação não ocorrerá. A concentração e } \\
\text { composição do fluido de corte devem ser } \\
\text { cuidadosamente controladas para uma boa flotação. }\end{array}$ \\
\hline $\begin{array}{l}\text { Separadores } \\
\text { magnéticos }\end{array}$ & $\begin{array}{l}\text { Removem partículas ferrosas e outras ligas magnéticas utilizando um } \\
\text { tambor rotativo magnetizado ou correia magnetizada. O dispositivo } \\
\text { magnético atrai as partículas metálicas, levando-as para fora da área do } \\
\text { fluxo do fluido de corte. Em alguns equipamentos existem acessórios } \\
\text { raspadores que fazem a remoção final das partículas. } \\
\text { Indicados para fluidos de corte aquosos e integrais de baixa viscosidade. } \\
\text { No caso de tambores, o entrelaçamento das partículas de impurezas } \\
\text { magnetizadas formam uma rede que carrega também partículas não } \\
\text { metálicas, favorecendo a limpeza. }\end{array}$ & $\begin{array}{l}\text { Tem limitações de tamanho e capacidade de fluxo de } \\
\text { fluido, portanto são adequados para uso em uma ou } \\
\text { duas máquinas. }\end{array}$ \\
\hline
\end{tabular}

Fonte: Elaborado a partir de CIMM, 2011. 
Atualmente a empresa vende os cavacos com fluido de corte a sucateiros da região. Através da média dos valores de venda informados pela Indústria $X$, praticados entre março e agosto de 2010, verificou-se que o quilo do cavaco com fluido é de $R \$ 0,12$. Utilizando-se este valor como parâmetro, a empresa obtém um lucro de $\mathrm{R} \$ 6.327,00 /$ ano com a venda deste resíduo.

Com o emprego de um método de separação a indústria pode obter uma maior valorização para a venda do cavaco limpo além de recuperar grande parte do fluído de corte que atualmente é perdido.

Considerando-se a adoção de uma estratégia de produção mais limpa com a separação e recuperação do fluído de corte e venda do cavaco limpo com o atual valor de venda, a empresa teria os seguintes lucros aproximados:

Tabela 4 - Comparação dos lucros anuais entre a situação atual e com a adoção de uma estratégia de produção mais limpa.

\begin{tabular}{lcc}
\hline & Situação Atual & Situação com P+L \\
\hline Lucro com a recuperação do fluído de corte & $\mathrm{R} \$ 4.446,00$ & $\mathrm{R} \$ 14.212,00^{*}$ \\
Lucro com a venda do cavaco & $\mathrm{R} \$ 6.327,00^{* \star}$ & $\mathrm{R} \$ 5.891,00$ \\
\hline TOTAL & $\mathbf{R} \$ \mathbf{1 0 . 7 7 3 , 0 0}$ & $\mathbf{R} \$ \mathbf{2 0 . 1 0 3 , 0 0}$ \\
\hline Nota: & \\
* Sem considerar os custos de investimento para aquisição do equipamento de separação do cavaco \\
e fluído de corte.
\end{tabular}

A partir dos valores apresentados na Tabela 4 nota-se que com a adoção da estratégia proposta a empresa teria um lucro aproximado de $R \$ 20.103,16 / a n o$, ou seja, $R \$ 9.329,92$ a mais do que a situação atual.

Outra possibilidade de produção mais limpa que deve ser mencionada é a modificação da tecnologia. Apesar de implicar em investimentos mais altos devido a necessidade de aquisição e implantação de novos equipamentos e ferramentas a modificação da tecnologia pode contribuir para a redução do impacto ambiental causado principalmente pelos fluídos esgotados.

A tecnologia convencionalmente utilizada para a refrigeração no processo de usinagem é de inundação, ou seja, uma grande quantidade de fluido de corte é lançada continuamente na região de corte, exigindo por conseqüência o consumo de um grande volume de fluido (OLIVEIRA \& ALVES, 2007). 
Dentre as alternativas atualmente estudadas para a minimização ou mesmo eliminação dos fluídos de corte tem-se: mínima quantidade de lubrificante (MQL) e usinagem a seco.

$\mathrm{Na}$ técnica de mínima quantidade de lubrificante (MQL) uma quantidade mínima de óleo é pulverizada em um fluxo de ar comprimido. Suas vantagens em relação à usinagem com fluido abundante são: redução do volume de descarte, produção de peças e cavacos mais limpos, redução de custos de processamento, limpeza e acondicionamento. Já quanto as desvantagens têm-se: produção de névoa e fumaça de óleo, considerados indesejáveis pois contribuem para aumentar o índice de poluentes em suspensão no ar, implicando na necessidade da implantação de um bom sistema de exaustão na máquina (OLIVEIRA \& ALVES, 2007).

No método de usinagem a seco, como o próprio nome diz, não é utilizado fluído de corte. Segundo o CNTL (2006) a usinagem a seco é utilizada em processos com corte interrompido, como o fresamento, podendo ser aplicada em algumas situações de cortes contínuos.

"Só é viável quando o tempo de usinagem, o tempo de vida da ferramenta e a qualidade superficial da peça for pelo menos semelhante à conseguida com a usinagem usando-se fluídos de corte tradicionais." (OLIVEIRA \& ALVES, 2007, p. 136).

As vantagens desta tecnologia são o atendimento aos requisitos ecológicos, redução de custos (eliminação do fluido) e aumento da produtividade (devido ao incremento nos parâmetros de usinagem). Dentre as desvantagens têm-se: problemas provocados pelas poeiras produzidas (associados à usinagem de ferros fundidos), maior solicitação térmica da peça e necessidade de ferramentas especiais (OLIVEIRA \& ALVES, 2007). 


\section{CONSIDERAÇÕES FINAIS}

O Plano de Gerenciamento de Resíduos (PGRS) desenvolvido e implementado em conjunto com um programa de produção mais limpa podem ser importantes aliados para que as empresas gerenciem seus resíduos de forma adequada e com o emprego de medidas preventivas.

Notou-se durante a pesquisa que a indústria de usinagem já adota algumas ações de gerenciamento preventivo, como por exemplo, o emprego de embalagens retornáveis para acondicionamento do produto final, reaproveitamento de parte do fluído de corte perdido com o cavaco e o uso de panos de limpeza recicláveis. Apesar disso, as ações são realizadas de maneira desarticulada, pela falta de informações mais aprofundadas quanto aos resíduos e as possibilidades de reduzir sua geração.

De maneira geral as oportunidades de melhoria no gerenciamento dos resíduos sólidos identificadas ao longo da pesquisa estão resumidas no Quadro 22.

Quadro 22 - Resumo das oportunidades de melhoria no gerenciamento dos resíduos identificadas.

\begin{tabular}{|l|l|}
\hline Foco de Ação & Oportunidades de melhoria identificadas \\
\hline Geral & $\begin{array}{l}\text { - Elaboração e implantação do Plano de Gerenciamento de Resíduos Sólidos } \\
\text { (PGRS), com revisões periódicas. }\end{array}$ \\
\hline $\begin{array}{l}\text { Manuseio dos } \\
\text { resíduos }\end{array}$ & $\begin{array}{l}\text { - Monitorar a situação dos recipientes de acondicionamento dos resíduos, } \\
\text { realizando substituiçoses quando necessário. } \\
\text { - Adequar a área de armazenamento dos resíduos oleosos. }\end{array}$ \\
\hline $\begin{array}{l}\text { Produção mais } \\
\text { limpa }\end{array}$ & $\begin{array}{l}\text { - Exigir maior padronização no comprimento das barras de aço adquiridas. } \\
\text { - Desenvolver procedimentos para evitar a contaminação e o descarte do fluído } \\
\text { de corte (boas práticas de fabricação). } \\
\text { - Realizar a separação do cavaco e fluído de corte, reutilizando o último no } \\
\text { processo. }\end{array}$ \\
\hline Pesquisa & $\begin{array}{l}\text { - Desenvolver estudos junto com os clientes quanto o design das peças. } \\
\text { - Desenvolver estudos internos ou em parceria com Instituições de ensino e } \\
\text { pesquisa para verificar a viabilidade do emprego de tecnologia alternativa para } \\
\text { redução da geração de resíduos no processo. }\end{array}$ \\
\hline
\end{tabular}

Mesmo os levantamentos tendo sido realizados apenas para a peça $A$, as melhorias propostas poderão beneficiar o gerenciamento dos resíduos na empresa de uma maneira geral. Na elaboração do PGRS a definição de indicadores para as 
outras peças produzidas poderão inclusive abrir caminho para a implantação de novas melhorias e metas de redução que poderão ser perseguidas pela empresa.

O manuseio adequado dos resíduos garante além do atendimento às normas e legislação maior segurança para os funcionários e o meio ambiente, como também a empresa tem menores chances de receber autuações dos órgãos ambientais.

Das oportunidades propostas de produção mais limpa a separação do cavaco e do fluído de corte é a única que necessita de investimentos iniciais para aquisição de equipamento, o que pode implicar em uma barreira. Deve-se notar que com o emprego da separação do fluído de corte a empresa teria um lucro aproximado de $\mathrm{R} \$$ 9.329,92/ano, com a reutilização do fluído atualmente perdido e a venda do cavaco limpo. Isso sem contar com os benefícios ambientais de redução do consumo dos recursos naturais.

Por fim, é importante que as indústrias entendam que as estratégias de gerenciamento dos resíduos devem ser aplicadas e aprimoradas constantemente. Trata-se, portanto, de um esforço contínuo no qual o papel da universidade pode ser de extrema relevância para o desenvolvimento de pesquisas que auxiliem na proposição dos novos caminhos e estratégias para o gerenciamento preventivo dos resíduos. 


\section{REFERÊNCIAS ${ }^{36}$}

ALBIERO FILHO, A. (Coord). Indicadores de Desempenho Ambiental da Indústria. São Paulo: Federação e Centro das Indústrias do Estado de São Paulo FIESP/CIESP. Disponível em: <http://www.fiesp.com.br/download/ publicacoes_meio_ambiente/cartilha_indic_ambiental.pdf>Acesso em: 11 nov. 2010.

ARAÚJO, J. B. Avaliação de processos de manufatura considerando parâmetros de sustentabilidade. 2010. 193f. Tese (Doutorado em Engenharia de Produção) - Escola de Engenharia de São Carlos, Universidade de São Paulo, São Carlos, 2010.

ASSOCIAÇÃO BRASILEIRA DE NORMAS TÉCNICAS - ABNT. NBR 10.004: resíduos sólidos - classificação. Rio de Janeiro, 2004a. 71p.

NBR 10.007: amostragem de resíduos sólidos. Rio de Janeiro, 2004b. 21p.

NBR 11.174: armazenamento de resíduos classe II - não inertes e III inertes. Rio de Janeiro, 1990. 7p.

NBR 12.235: armazenamento de resíduos sólidos perigosos. Rio de Janeiro, 1992. 14p.

NBR 13.221: transporte de resíduos. Rio de Janeiro, 2000. 5p.

BARBIERI, J. C. Desenvolvimento e meio ambiente: as estratégias de mudança da agenda 21. Petrópolis: Vozes, 2007. 157p.

BARDAHL. Contaminação de óleos de corte. Case Técnico. Revista LUBGRAX. 2010, mar/abr, p. 44-46.

BIDONE, F. A. (Coord). Resíduos Sólidos Provenientes de Coletas Especiais: eliminação e valorização. Prosab, 2001. 217p.

BIERMANN, M. J. E. Gestão de Fluídos de Usinagem. nov. 2008. Disponível em: < http://www.fiepr.org.br/fiepr/conselhos/meio_ambiente> Acesso em: 11 set. 2010.

\footnotetext{
${ }^{36}$ De acordo com a Associação Brasileira de Normas Técnicas. NBR 6023.
} 
BRASIL. Decreto n.․ 7.404, de 23 de dezembro de 2010. Regulamenta a Lei n.. 12.305, de 2 de agosto de 2010, que institui a Política Nacional de Resíduos Sólidos, cria o Comitê Interministerial da Política Nacional de Resíduos Sólidos e o Comitê Orientador para a Implantação dos Sistemas de Logística Reversa, e dá outras providências. Disponível em: <http://www.planalto.gov.br/ccivil_03/_Ato20072010/2010/Decreto/D7404.htm> Acesso em: 10 fev. 2011.

BRASIL. Lei n. ${ }^{\circ}$ 12.305, de 02 de agosto de 2010. Institui a Política Nacional de Resíduos Sólidos; altera a Lei 9605, de 12 de fevereiro de 1998; e dá outras providências. Disponível em: <http://www.planalto.gov.br/ccivil_03/_ato20072010/2010/lei/l12305.htm> Acesso em: 29 set. 2010.

BRASIL. Portaria Minter n. ${ }^{\circ}$ 124, de 20 de agosto de 1980. Estabelece normas para a localização de indústrias potencialmente poluidoras junto à coleções hídricas. Disponível em: <http://www.ima.al.gov.br/legislacao/portariasministeriais/Portaria\%20nb0\%20124.80.pdf> Acesso em: 23 jul. 2010.

CATAI, R. E.; BIANCHI, E. C.; SILVA, L. R.; AGUIAR, P. R.; CATAI, D. Aplicação de Fluídos de Corte no Processo de Retificação. Revista de Ciência \& Tecnologia. 2003 , v. 11 , n. 22 , p. 7-18.

CARDOSO, A. O. Introdução ao Plano de Gerenciamento de Resíduos Sólidos PGRS. Porto Alegre: CNTL/SENAI, 2008. Disponível em: <http://www.senairs.org.br/ $\mathrm{cntl} />$ Acesso em: 11 set. 2010.

CENTRO DE INFORMAÇÃO METAL MECÂNICA - CIMM. Usinagem. Disponível em: <http://www.cimm.com.br/portal/usinagem> Acesso em: 18 set. 2010.

CENTRO DE INFORMAÇÃO METAL MECÂNICA - CIMM. Purificação de Fluidos de Corte. Disponível em: <http://www.cimm.com.br/portal/material_didatico/4834purificacao-de-fluidos-de-corte> Acesso em: 04 mar. 2011.

CENTRO NACIONAL DE TECNOLOGIAS LIMPAS - CNTL. Implementação de Programas de Produção mais limpa. Porto Alegre: CNTL SENAI RS/UNIDO/UNEP, 2003a. 42p.

Questões Ambientais e Produção mais Limpa. Porto Alegre: UNIDO, UNEP, CNTL SENAI - RS, 2003b. 126p. (Série Manuais de Produção mais Limpa).

Cinco fases da Implantação de técnicas de produção mais limpa. Porto Alegre: UNIDO, UNEP, CNTL SENAI - RS, 2003c. 103p. (Série Manuais de Produção mais Limpa). 
Indicadores Ambientais e de Processo. Porto Alegre: UNIDO, UNEP, CNTL SENAI - RS, 2003d. 103p. (Série Manuais de Produção mais Limpa).

Projeto Programa Piloto para a minimização dos impactos gerados por resíduos perigosos. Documento 3 - Gestão de resíduos fluidos de usinagem. Rio Grande do Sul: CNTL-SENAI, 2006. 42p.

COMPANHIA DE TECNOLOGIA DE SANEAMENTO AMBIENTAL - CETESB. Manual para implementação de um programa de prevenção à poluição. São Paulo: CETESB, 2002. 16p. Disponível em: <http://www.cetesb.sp.gov.br/ Tecnologia/producao_limpa/documentos/manual_implem.pdf>. Acesso em: 15 abr. 2010.

Produção + Limpa. Disponível em: <http://www.cetesb.sp.gov.br/ Tecnologia/producao_limpa/apresentacao.asp> Acesso em: 07 set. 2010.

CONSELHO EMPRESARIAL BRASILEIRO PARA O DESENVOLVIMENTO SUSTENTÁVEL - CEBDS. Guia da produção mais limpa. 2003. Disponível em: <http://www.cebds.org.br/cebds/eco-rbe-publicacoes.asp> Acesso em: 06 set. 2009.

CONSELHO NACIONAL DO MEIO AMBIENTE. Resolução CONAMA n. ${ }^{\circ} 264$, de 26 de agosto de 1999. Licenciamento de fornos rotativos de produção de clínquer para atividades de co-processamento de resíduos. Resoluções do Conama: resoluções vigentes publicadas entre julho de 1984 e novembro de 2008. 2ed. Brasília: Conama, 2008. 928p.

CONSELHO NACIONAL DO MEIO AMBIENTE. Resolução CONAMA n. ${ }^{\circ} 275$, de 25 de abril de 2001. Estabelece o código de cores para os diferentes tipos de resíduos, a ser adotado na identificação de coletores e transportadores, bem como nas campanhas informativas para a coleta seletiva. Resoluções do Conama: resoluções vigentes publicadas entre julho de 1984 e novembro de 2008. 2ed. Brasília: Conama, 2008. 928p.

CONSELHO NACIONAL DO MEIO AMBIENTE. Resolução CONAMA n. ${ }^{\circ}$ 313, de 29 de outubro de 2002. Dispõe sobre o Inventário Nacional de Resíduos Sólidos Industriais. Resoluções do Conama: resoluções vigentes publicadas entre julho de 1984 e novembro de 2008. 2ed. Brasília: Conama, 2008. 928p.

CONSELHO NACIONAL DO MEIO AMBIENTE. Resolução CONAMA n. ${ }^{\circ} 316$, de 29 de outubro de 2002. Dispõe sobre o procedimentos e critérios para o funcionamento de sistemas de tratamento térmico de resíduos. Resoluções do Conama: resoluções vigentes publicadas entre julho de 1984 e novembro de 2008. 2ed. Brasília: Conama, 2008. 928p. 
COSTA, E. S.; SANTOS, D. J. Processos de Usinagem. (Apostila). Divinópolis:

Centro Federal de Educação Tecnológica de Minas Gerais - CEFET-MG, 2006. 85p.

ENVIRONMENT CANADA - EC. Pollution Prevention Planning Handbook. Disponível em: <http://www.ec.gc.ca/planp2-p2plan/default.asp?lang=En\&n= 56875F44-1\&offset=1\&toc=show>. Acesso em: 15 abr. 2010.

ESTADÃO. BP confirma fim de vazamento de petróleo no Golfo do México. Estadão.com.br, São Paulo, 09 ago. 2010. Disponível em: < http://www.estadao.com.br/noticias/internacional,bp-confirma-fim-de-vazamento-depetroleo-no-golfo-do-mexico,592447,0.htm> Acesso em: 06 nov. 2010.

GALBIATI, A. F. O Gerenciamento Integrado de Resíduos Sólidos e a Reciclagem. Disponível em: < http://www.amda.org.br/objeto/arquivos/97.pdf> Acesso em: 15 jul. 2010.

JÚNIOR, V. S.; CASTRO, P. S.; DELFORGE, D. Y. M. Bolsa de Resíduos. In: XI CREEM - Congresso Nacional de Estudantes de Engenharia Mecânica. 2004, Nova Friburgo. Disponível em: < http://www.abcm.org.br/xi_creem/resumos/SA/CRE04SA01.pdf> Acesso em: 15 jul. 2010.

LAGREGA, M. D., BUCKINGHAM, P. L., EVANS, J. C. Hazardous Waste Management. ISBN 0-07-019552-8. McGraw-Hill Book Co., 1994. 1.146p.

LORA, E. S. Prevenção e Controle da Poluição nos Setores Energético, Industrial e de Transporte. Brasília: ANEEL, 2000.503p.

LUGLI, D. Diagrama de causa-efeito. 2009. Disponível em: <http://www.lugli.org/ 2009/08/diagrama-de-causa-efeito-ishikawa/> Acesso em: 14 nov. 2010.

LUND, H. F. The McGraw-Hill Recycling Handbook. United States of America: McGraw-Hill, 1993.

MACHADO, A. R.; ABRÃO A. M.; COELHO, R. T.; SILVA, M. B. Teoria da Usinagem dos Materiais. São Paulo: Editora Blucher, 2009. 371p.

MAROUN, C. A. Manual de Gerenciamento de Resíduos: guia de procedimento passo a passo. 2.ed. Rio de Janeiro: GMA, 2006. 16p.

MONTEIRO, J. H. P. Manual de Gerenciamento Integrado de resíduos sólidos. Rio de Janeiro: IBAM, 2001. 193p. 
MOORS, E.H.M; MULDER, K. F.; VERGRAGT, P. J. Towards cleaner production: barriers and strategies in the base metals producing industry. Journal of Cleaner Production. 2005, v.13, p. 657-668.

NAIME, R. Diagnóstico Ambiental e Sistemas de Gestão Ambiental: incluindo a atualização da série ISO 9000 e as novas NBR 14001/2004 e NBR ISO 19011/2002. Novo Hamburgo: Feevale, 2005. 168p.

NAIME, R.; GARCIA, A. C. A. Percepção ambiental e diretrizes para compreender a questão do meio ambiente. Novo Hamburgo: Feevale, 2004. $136 p$.

OURA, M. M.; SOUZA, M. T. S. A evolução das tecnologias end-of-pipe às tecnologias limpas em indústria de equipamentos de torrefação de café. In: XXVII Encontro Nacional de Engenharia de Produção. 2007, Foz do Iguaçu. Disponível em: <http://www.abepro.org.br/biblioteca/ENEGEP2007_TR650481_ 9861.pdf>. Acesso em: 15 abr. 2010.

OLIVEIRA, J. A. Otimização ambiental de um sistema de produção de petróleo baseada em critérios de produção mais limpa. 2006. 222f. (Mestrado em Gerenciamento e Tecnologias Ambientais no Processo Produtivo) - Escola Politécnica, Universidade Federal da Bahia, Salvador, 2006.

OLIVEIRA, J. F. G.; ALVES, S. M. Adequação ambiental dos processos usinagem utilizando Produção mais Limpa como estratégia de gestão ambiental. Produção, v. 17, n. 1, p. 129-138, jan/abr 2007.

PHILIPPI JR., A. (Ed.). Saneamento, Saúde e Ambiente: fundamentos para um desenvolvimento sustentável. Barueri, SP: Manole, 2005. 842p. (Coleção Ambiental, 2).

PNUMA. A Produção mais limpa e o consumo sustentável na América Latina e Caribe. PNUMA/CETESB: São Paulo, 2005. 134p. Disponível em: < http://www.cetesb.sp.gov.br/Tecnologia/producao_limpa/documentos.asp> Acesso em: 15 abr. 2010.

ROCCA, A.C.C. Resíduos Sólidos Industriais. 2. ed. São Paulo: CETESB, 1993. 234p.

SANCHES, C. S. Gestão Ambiental Proativa. RAE - Revista de Administração de Empresas, São Paulo, v. 40, n. 1, p. 76-87, jan./mar. 2000. 
SANTOS, C. Curso de Gerenciamento de Resíduos Industriais. Cuiabá: 3 Irmãos Eventos e Treinamentos, 2006. CD-ROM.

SANTOS, C. Prevenção a Poluição Industrial: oportunidades, análise dos benefícios e barreiras. 2005. 287f. Tese (Doutorado em Ciências da Engenharia Ambiental) - Escola de Engenharia de São Carlos, Universidade de São Paulo, São Carlos, 2005.

SANTOS, M. S; YAMANAKA, H. T.; PACHECO, C. E. M. Bijuterias. Série P+L. São Paulo: CETESB, 2005. 54p. Disponível em: <http://www.cetesb.sp.gov.br>. Acesso em: 27 mar. 2010.

SÃO PAULO. Lei Estadual n.ำ 12.300, de 16 de março de 2006. Institui a Política Estadual de Resíduos Sólidos e define princípios e diretrizes. Disponível em: <http://www.ambiente.sp.gov.br/legislacao/estadual/leis/2006\%20Lei\%2012300.pdf> Acesso em: 14 dez. 2010.

SEBRAE. Critérios de Classificação de empresas. Disponível em: $<$ http://www.sebrae-sc.com.br/leis/default.asp?vcdtexto=4154> Acesso em: 04 dez. 2010.

SEIFFERT, M. E. B. Gestão Ambiental: instrumentos, esferas de ação e educação ambiental. São Paulo: Atlas, 2007. 310p.

SILVA, E. L.; MENEZES, E. M. Metodologia da Pesquisa e Elaboração de Dissertação. 3 ed. rev. atual. Florianópolis: Laboratório de Ensino a Distância da UFSC, 2001. 121p.

SOARES, G. F. S. A Proteção Internacional do Meio Ambiente. Barueri: Manole, 2003.

SOKOVIC, M.; MIJANOVIC, K. Ecological aspects of the cutting fluids and its influence on quantifiable parameters of the cutting processes. Journal of Materials Processing Technology, v. 109, p. 181-189, 2001.

STOETERAU, R. L. Introdução aos processos de usinagem. Disponível em: <http://www.Imp.ufsc.br/disciplinas/emc5240/Aula-01-U-2007-1-Introducao.pdf> Acesso em: 21 ago. 2010.

TCHOBANOGLOUS, G.; THEISEN, H.; VIGIL, S. A. Integrated Solid Waste Management: engeneering principles and management issues. New York: McGrawHill Science Engineering, 1993. 978p. ISBN 0-07-063237-5 
TOCCHETTO, M. R. L. Curso de Tratamento de Efluentes Líquidos e Gerenciamento de Resíduos Sólidos Industriais: parte 2 - resíduos sólidos. Cuiabá, 2007. 152p.

UNITED NATIONS ENVIRONMENT PROGRAMME - UNEP. Cleaner Production in Latin America and Caribbean. United Nations Publication, 2002a. Disponível em $<$ http://www.cetesb.sp.gov.br/Tecnologia/ producao_limpa/documentos.asp> Acesso em: 15 abr. 2010.

Sustainable Consumption and Cleaner Production: global status 2002. UNEP, 2002b. 24p. ISBN: 92-807-2073-2.

. Resource Efficient and Cleaner Production. Disponível em: < http://www.uneptie.org/scp/cp/>. Acesso em: 15 abr. 2010. 


\section{GLOSSÁRIO}

Corrosividade: Um resíduo é caracterizado como corrosivo se uma amostra representativa dele, apresentar uma das seguintes propriedades:

a) ser aquosa e apresentar $\mathrm{pH}$ inferior ou igual a 2, ou, superior ou igual a 12,5, ou sua mistura com água, na proporção de 1:1 em peso, produzir uma solução que apresente $\mathrm{pH}$ inferior a 2 ou superior ou igual a 12,5;

b) ser líquida ou, quando misturada em peso equivalente de água, produzir líquido e corroer o aço a uma razão maior que $6,35 \mathrm{~mm}$ ao ano, a uma temperatura de $55^{\circ} \mathrm{C}$.

Critérios de classificação das empresas: O SEBRAE utiliza como critério de classificação do porte das empresas, para fins bancários, ações de tecnologia, exportação e outros, o número de empregados levantados pelo Instituto Brasileiro de Geografia e Estatística (IBGE), a saber:

- Para indústria:

Micro: com até 19 empregados;

Pequena: de 20 a 99 empregados;

Média: 100 a 499 empregados;

Grande: mais de 500 empregados

- Para comércio e serviços:

Micro: com até 9 empregados;

Pequena: de 10 a 49 empregados;

Média: 50 a 99 empregados;

Grande: mais de 100 empregados

Inflamabilidade: Um resíduo sólido é caracterizado como inflamável, se uma amostra representativa dele, obtida conforme a ABNT NBR 10.007, apresentar qualquer uma das seguintes propriedades:

a) ser líquida e ter ponto de fulgor inferior a $60^{\circ} \mathrm{C}$, excetuando-se as soluções aquosas com menos de $24 \%$ de álcool em volume;

b) não ser líquida e ser capaz de, sob condições de temperatura e pressão de $25^{\circ} \mathrm{C}$ e 1 atm, produzir fogo por fricção, absorção de umidade ou por alterações químicas espontâneas e, quando inflamada, queimar vigorosa e persistentemente, dificultando a extinção do fogo; 
c) ser um oxidante e, como resultado, estimular a combustão e aumentar a intensidade do fogo em outro material;

d) ser um gás comprimido inflamável.

Patogenicidade: Um resíduo é caracterizado como patogênico se uma amostra representativa dele, contiver ou se houver suspeita de conter, microorganismos patogênicos, proteínas virais, ácido desoxiribonucléico (ADN) ou ácido ribonucléico (ARN) recombinantes, organismos geneticamente modificados, plasmídios, cloroplastos, mitocôndrias ou toxinas capazes de produzir doenças em homens, animais ou vegetais.

Reatividade: Um resíduo é caracterizado como reativo se uma amostra representativa dele, apresentar uma das seguintes propriedades:

a) ser normalmente instável e reagir de forma violenta e imediata, sem detonar;

b) reagir violentamente com a água;

c) formar misturas potencialmente explosivas com a água;

d) gerar gases, vapores e fumos tóxicos em quantidades suficientes para provocar danos à saúde pública ou ao meio ambiente, quando misturados com a água;

e) possuir em sua constituição os íons $\mathrm{CN}^{-}$ou $\mathrm{S}^{-2}$ em concentrações que ultrapassem os limites de $250 \mathrm{mg}$ de HCN liberável por quilograma de resíduo ou $500 \mathrm{mg}$ de $\mathrm{H}_{2} \mathrm{~S}$ liberável por quilograma de resíduo;

f) ser capaz de produzir reação explosiva ou detonante sob a ação de forte estímulo, ação catalítica ou temperatura em ambientes confinados;

g) ser capaz de produzir, prontamente, reação ou decomposição detonante ou explosiva a $25^{\circ} \mathrm{C}$ e $1 \mathrm{~atm}$;

h) ser explosivo, definido como uma substância fabricada para produzir um resultado prático, através de explosão ou efeito pirotécnico, esteja ou não esta substância contida em dispositivo preparado para este fim.

Toxicidade: Um resíduo é caracterizado com tóxico se uma amostra representativa dele, apresentar uma das seguintes propriedades:

a) quando o extrato obtido desta amostra contiver qualquer um dos contaminantes em concentrações superiores aos valores constantes no anexo F; 
b) possuir uma ou mais substâncias constantes no anexo $\mathrm{C}$ e apresentar toxicidade. Para avaliação dessa toxicidade, devem ser considerados os seguintes fatores:

- natureza da toxicidade apresentada pelo resíduo;

- concentração do constituinte no resíduo;

- potencial que o constituinte, ou qualquer produto tóxico de sua degradação, tem para migrar do resíduo para o ambiente, sob condições impróprias de manuseio;

- persistência do constituinte ou qualquer produto tóxico de sua degradação;

- potencial que o constituinte, ou qualquer produto tóxico de sua degradação, tem para degradar-se em constituintes não perigosos, considerando a velocidade em que ocorre a degradação;

- extensão em que o constituinte, ou qualquer produto tóxico de sua degradação, é capaz de bioacumulação nos ecossistemas;

- efeito nocivo pela presença de agente teratogênico, mutagênico, carcinogênico ou ecotóxico, associados a substâncias isoladamente ou decorrente do sinergismo entre as substâncias constituintes do resíduo;

c) ser constituída por restos de embalagens contaminadas com substâncias constantes nos anexos D ou E;

d) resultar de derramamentos ou de produtos fora de especificação ou do prazo de validade que contenham quaisquer substâncias constantes nos anexos $D$ ou $E$;

e) ser comprovadamente letal ao homem;

f) possuir substância em concentração comprovadamente letal ao homem. 


\section{APÊNDICE A}

Formulário de Pesquisa - Fase: Levantamento Preliminar 


\section{FORMULÁRIO DE PESQUISA}

Fase: Levantamento preliminar

\section{I - Informações Gerais}

1.1 Razão Social:

1.2 Nome do responsável:

1.3 Função/Cargo:

1.4 Telefone: 1.6 E-mail:

1.5 Atividade principal da indústria:

1.7 Código CNAE: 1.8 Porte:

1.9 Período de funcionamento:

Horas por dia: Dias na semana: Meses do ano:

1.10 Núm. total funcionários:

\section{II - Aspectos Ambientais}

2.1 Possui Licença Ambiental? ( )Não ( )Sim

2.2 Já recebeu alguma notificação ou penalidade referente ao gerenciamento dos resíduos?

( )Não ( )Sim

2.3 Possui um setor ou pessoa responsável pelos assuntos ambientais? ( )Não ( )Sim

2.4 Possui Certificação? ( )Não ( )Sim Qual?

2.5 Possui Sistema de Gestão Ambiental? （ )Não ( )Sim 
2.6 Possui Plano de Gerenciamento de Resíduos Sólidos? （ )Não （ )Sim

2.7 Possui Inventário dos Resíduos Sólidos? （ )Não ( ) Sim

2.8 Mantém registro dos resíduos gerados, armazenados ou vendidos? （ )Não（）Sim

2.9 Já desenvolveu um programa de Produção mais limpa? ( )Não ( )Sim

\section{III - Aspectos operacionais}

3.1 Quais são os produtos e/ou serviços produzidos na empresa? (Coluna 1)

3.2 Com qual mercado são comercializados (externo ou interno - local, estadual, nacional)? (Coluna 2)

\begin{tabular}{|l|l|l|l|l|}
\cline { 2 - 5 } \multicolumn{1}{c|}{} & \multicolumn{2}{c|}{ Coluna 1 } & Coluna 2 \\
\cline { 2 - 5 } \multicolumn{1}{c|}{ Produto } & Quantidade & Unidade & Mercado \\
\hline a & & & & \\
\hline b & & & & \\
\hline c & & & & \\
\hline d & & & & \\
\hline e & & & & \\
\hline f & & & & \\
\hline g & & & & \\
\hline h & & & & \\
\hline i & & & & \\
\hline j & & & & \\
\hline
\end{tabular}




\subsection{Fluxo do Processo}

(Indicar todas as entradas e saídas para cada etapa do processo produtivo e para cada linha de produção)

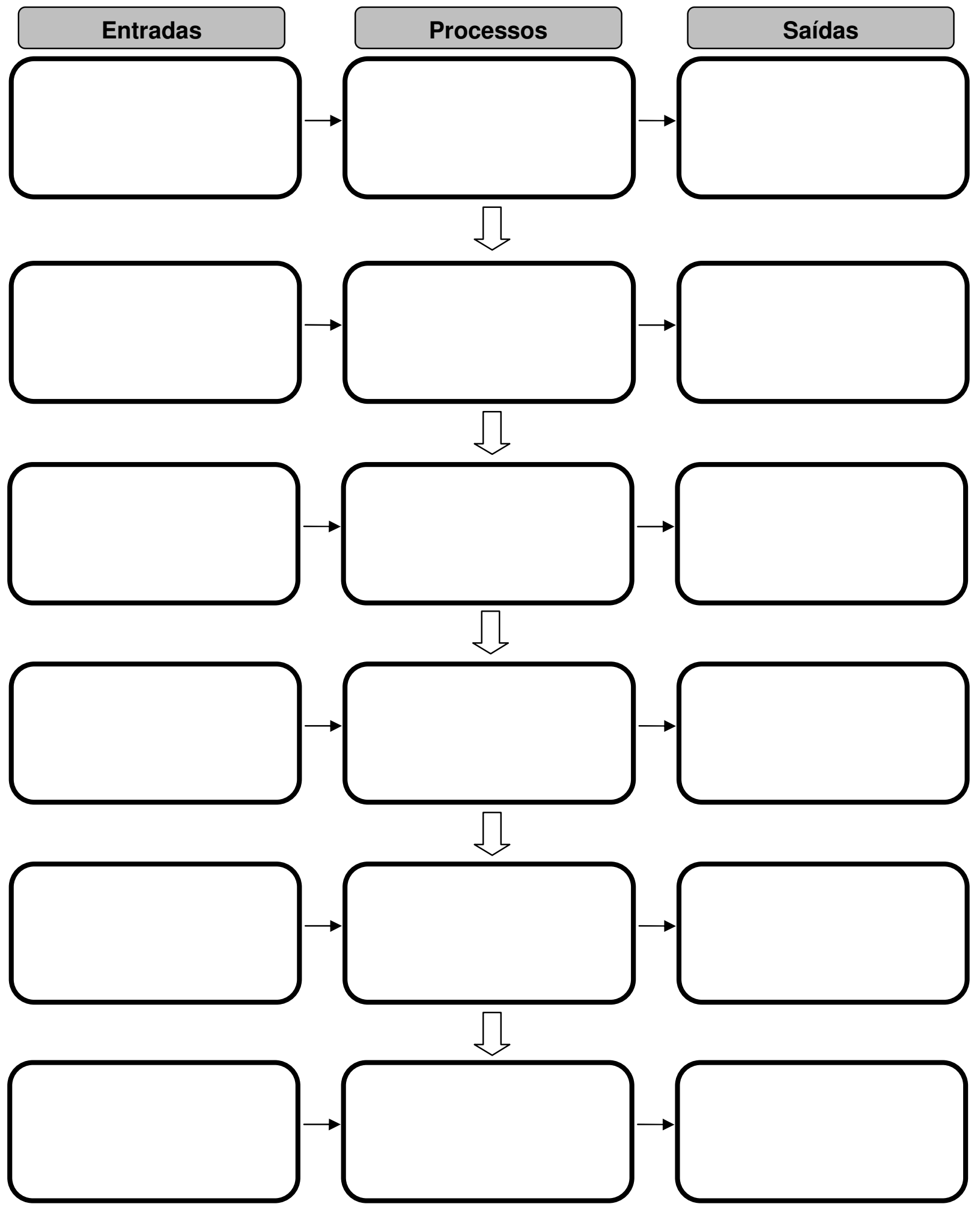


3.4 Dentre os resíduos gerados qual(is) a empresa tem apresentado maior dificuldade para o gerenciamento? Por quê?

\subsection{Lay-out da empresa}

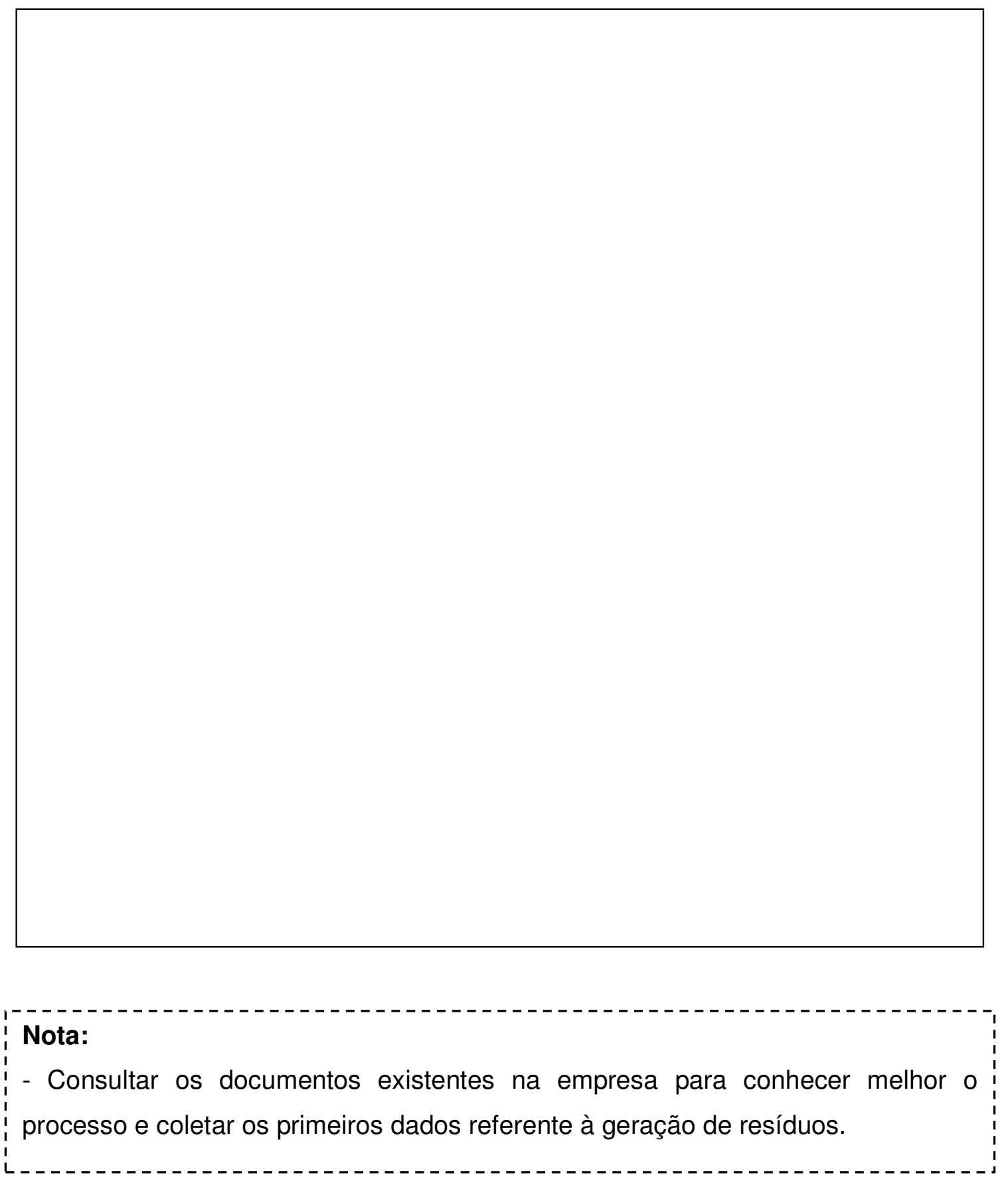




\section{APÊNDICE B}

Formulário de Pesquisa - Fase: Levantamento Detalhado 


\section{FORMULÁRIO DE PESQUISA}

Fase: Levantamento detalhado

\section{I - Quantificação dos resíduos}

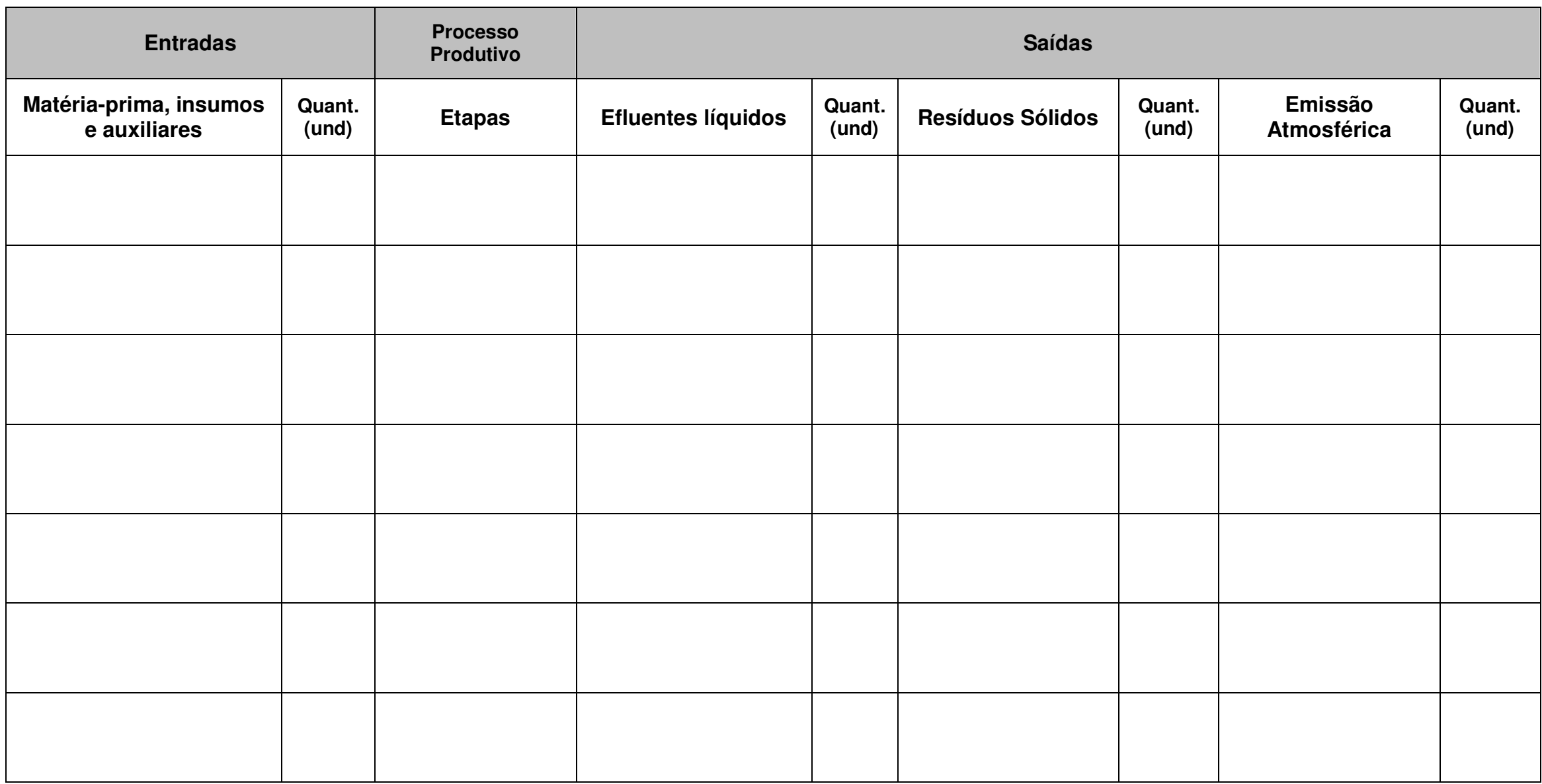


II - Gerenciamento dos resíduos

\begin{tabular}{|c|c|c|c|c|c|c|}
\hline Etapa & Resíduo & Acondicionamento & Armazenamento & Transporte interno & Transporte externo & $\begin{array}{l}\text { Disposição } \\
\text { final }\end{array}$ \\
\hline & & & & & & \\
\hline & & & & & & \\
\hline & & & & & & \\
\hline & & & & & & \\
\hline & & & & & & \\
\hline & & & & & & \\
\hline & & & & & & \\
\hline & & & & & & \\
\hline & & & & & & \\
\hline
\end{tabular}




\section{III - Descrição dos sistemas de controle de poluição (caso existentes)}

(Estação de Tratamento de Água - ETA/ Estação de Tratamento de Efluentes - ETE/ Central de Resíduos Sólidos/ Sistemas de Controle de Poluição do ar, entre outros)

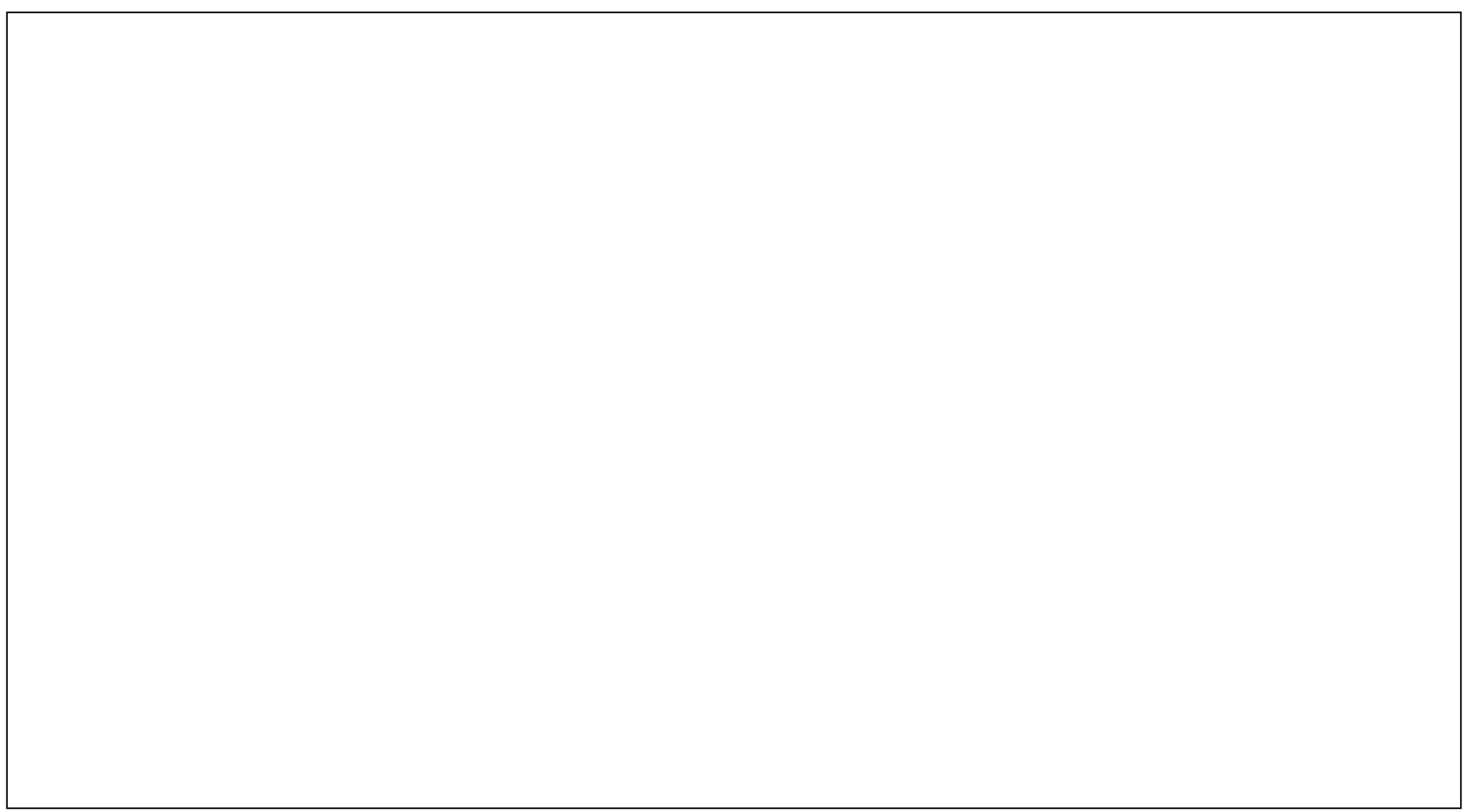


Página intencionalmente deixada em branco 